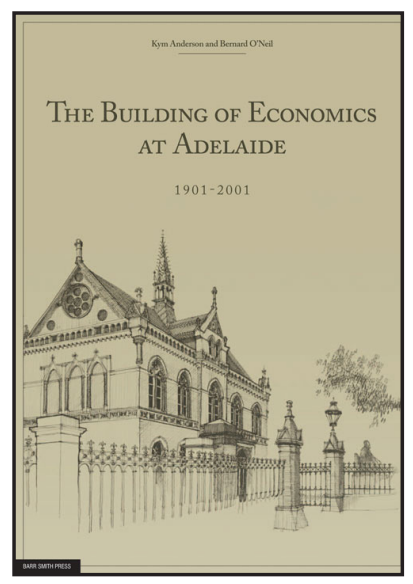

Welcome to the electronic edition of The Building of Economics at Adelaide, 1901-2001.

The book opens with the bookmark panel and you will see the contents page. Click on this anytime to return to the contents. You can also add your own bookmarks.

Each chapter heading in the contents table is clickable and will take you direct to the chapter. Return using the contents link in the bookmarks.

The whole document is fully searchable.

Enjoy. 
Kym Anderson and Bernard O’Neil

\section{The Building of Economics at Adelaide}

$1901-2001$

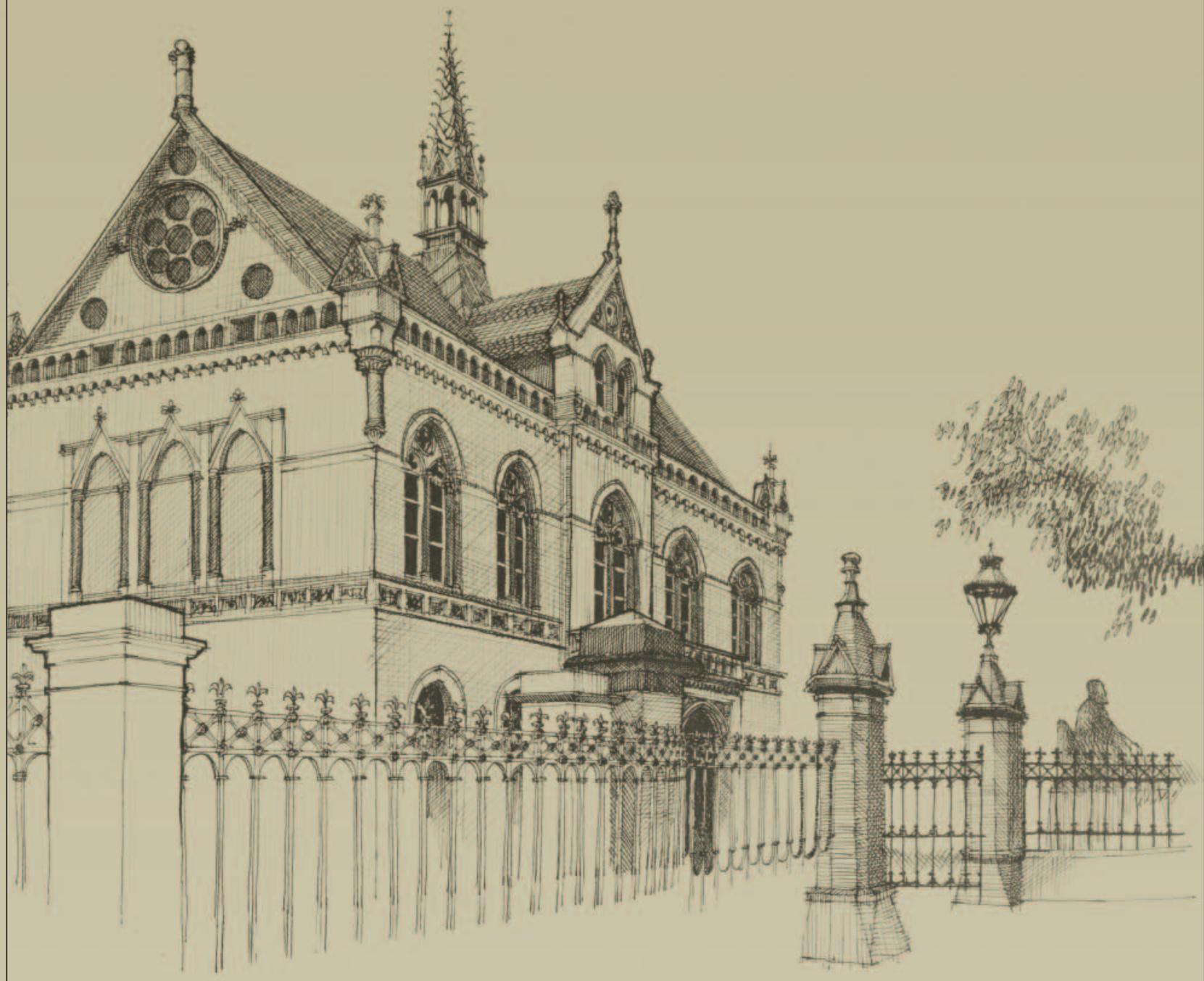




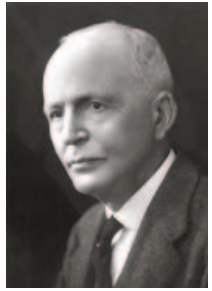

Sir William Mitchell

(1861-1962)

\section{The Building of Economics at Adelaide 1901 - 2001}

Kym Anderson and Bernard O’Neil

Modern undergraduate economics teaching at the University of Adelaide began in 1901. The University was founded in late 1874 and first offered subjects in March 1876. Twenty-five years later a core Economics undergraduate subject was introduced, and that year saw the first two B.A. students and first LL.B. student graduate after completing the subject. Thus it was that Adelaide became, in 1901-02, one of the world's earliest providers of tertiary economics and commerce courses.

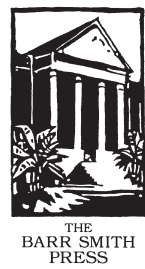




\section{The Building of Economics At Adelaide}

1901-2001 


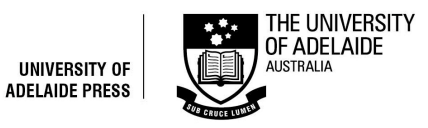

\section{Reprints Collection:}

\section{Economics}

As well as being established to publish high quality refereed new works the University of Adelaide Press selects previously published books by staff for reprinting both electronically and as softcover books.

Strengthening the Global Trading System

Indonesia in a Reforming World Economy

Reforming Trade Policy in Papua New Guinea and the Pacific Islands

The Economics of Quarantine

Global Wine Markets, 1961-2003

The Building of Economics at Adelaide

(Barr Smith Press imprint) 
Kym Anderson and Bernard O’Neill

\section{The Building of Economics At Adelaide}

1901-2001

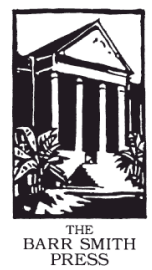




\section{Published in Adelaide by}

The University of Adelaide Press

Level 1, 254 North Terrace

University of Adelaide

South Australia

5005

press@adelaide.edu.au

www.adelaide.edu.au/press

The University of Adelaide Press publishes externally refereed scholarly books by staff of the University of Adelaide. It aims to maximise the accessibility to its best research by publishing works through the internet as free downloads and as high quality printed volumes on demand.

Electronic Index: this book is available as a downloadable PDF with fully searchable text.

This book is a facsimile republication. Some minor errors may remain. Originally published by the School of Economics, University of Adelaide.

(C) Kym Anderson and Bernard O’Neill 2002, 2004, 2009

First published 2002

Reprinted with minor corrections and updates 2004

Republished 2009

This work is licenced under the Creative Commons Attribution 3.0 Unported License. To view a copy of this licence, visit http://creativecommons.org/licenses/by/3.0/ or send a letter to Creative Commons, 444 Castro Street, Suite 900, Mountain View, California, 94041, USA. This licence allows for copying any part of the work for personal and commercial use, providing author attribution is clearly stated.

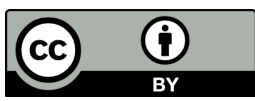

\section{Subject Keywords:}

University of Adelaide School of Economics History - Economics Study and Teaching (higher) South Australia Adelaide History - Economists South Australia Biography

For the full Cataloguing-in-Publication data please contact National Library of Australia: cip@nla.gov.au

ISBN 978-0-9806238-5-7 (electronic)

ISBN 978-0-9806238-6-4 (paperback)

Cover image: iStockphoto

Cover concept: Fiona Cameron

Cover design: Chris Tonkin 


\section{Contents}

Page

List of charts and tables vi

$\begin{array}{ll}\text { Preface } & \text { ix }\end{array}$

A chronology of the building of Economics at Adelaide $\quad x$

Chapter 1 Birth and adolescence, 1901-1949 1

The Mitchell years 1

The inter-war years 9

The 1940s 18

Chapter 2 Growth and adaptation, 1950-2001 21

The Karmel et al. years 21

The Jarrett et al. years 26

The Pincus et al. years 30

Chapter 3 Prospects for the next century 43

$\begin{array}{ll}\text { References } & 46\end{array}$

Appendix 1: Biographies of staff who became Professors 50

Appendix 2: Charts 67

Appendix 3: Tables $\quad 85$ 


\section{List of charts and tables}

\section{Appendix 2: Charts}

Chart 1: Economics Lecturers A-E by level, 1901-2002 68

Chart 2: $\quad$ Economics Lecturers B-E by level, 1946-2002 69

Chart 3: $\quad$ Economics Lecturers B-E by gender, 1946-2002 70

Chart 4: $\quad$ Commerce Lecturers A-E by level, 1954-2002 71

Chart 5: Advanced Certificate, Diploma and Bachelor $\quad 72$ graduates, 1904-1957

Chart 6: B.Ec. and B.Fin. graduates, 1945-2002 73

Chart 7: $\quad$ B.Ec., B.Com. and B.Fin. graduates, 1990-2002 74

Chart 8: $\quad$ B.Ec. admissions by gender, 1969-2002 75

Chart 9: Honours, Masters and Ph.D. graduates, 1945- 76 2002

Chart 10: Growth in double degree enrolments, 1992-2001 77

Chart 11: Double degree enrolments with B.Ec., 1992-2001 78

Chart 12: $\quad$ Double degree enrolments with B.Fin., 1997- $\quad 79$ 2001

Chart 13: $\quad$ Double degree enrolments with B.Com., 1992- 80 2001

Chart 14: $\quad$ Double degree enrolments with LL.B., 1992-2001 81

Chart 15: Double degree enrolments with B.A., 1992-2001 82

Chart 16: Double degree enrolments with B.Eng., 1992- 83 2001 
Table 1: Alphabetical list of full-time Economics

Lecturers, with years of service, 1901-2002

Table 2: Full-time Economics Lecturers by level of appointment and start date, 1901-2003

Table 3: Number of full-time Economics Lecturers at each level, by year, 1901-2003

Table 4: $\quad$ Titled, Emeritus and Adjunct Professors, 19592003

Table 5: Lecturers elected Fellows (and Presidents) of the learned academics, 1952-2002

Table 6: Lecturers who became chaired Professors (and Vice-Chancellors), by initial level of appointment at Adelaide, 1901-2002

Table 7: $\quad$ Alphabetical list of Ph.D. graduates, 1971-2003

Table 8: $\quad$ Titles of theses of Ph.D. graduates, by year of graduation, 1971-2003

Table 9: Alphabetical list of Masters graduates, 19502002

Table 10: Titles of theses of Masters graduates, by year of graduation, 1950-2002

Table 11: Alphabetical list of Honours graduates, 19452002

Table 12: Titles of theses of Honours graduates, by year of graduation, 1945-2002

Table 13: Alphabetical list of students completing a Graduate Certificate, Graduate Diploma or Applied Masters, 1990-2002

Table 14: Rhodes Scholars with a University of Adelaide major in Economics, 1938-2003 
Table 15: University awards in Economics and Commerce, 174 1901-2002

Table 16: Undergraduate graduations in Economics and Commerce, by award, 1904-1957

Table 17: Number of new B.Ec., B.Fin., M.Ec. and Ph.D. graduates, by award, 1945-2003

Table 18: Number of other new economics-related graduates, by award, 1989-2003

Table 19: South Australian Centre for Economic Studies 180 staff, 1982-2002

Table 20: Centre for International Economic Studies staff, 1989-2003

Table 21: Chinese Economies Research Centre staff, 19901999

Table 22: The Joseph Fisher Lectures and lecturers, 1904185 2003

Table 23: Deans, Assistants and Librarians of the Faculty 188 and Schools of Economics, Commerce and Graduate Business, 1946-2002

Table 24: Number of Lecturers E, D and B-E in Australian 192 teaching Departments of Economics with more than two Professors, 1987 and 2002

Table 25: Average Ph.D. and Masters thesis completion 193 times, 1948 to 2002

Table 26: School/Department of Economics working papers, 1970-2002

Table 27: South Australian Centre for Economic Studies 205 working papers and monographs, 1982-2002

Table 28: Centre for International Economic Studies 208 working papers and monographs, 1989-2002

Table 29: Chinese Economies Research Centre working 239 papers, 1990-1999 


\section{Preface}

A century of activity for an institution is a milestone too significant to go unacknowledged. Even though the resources needed to write a full historical account of the first century of economics at the University of Adelaide were not available, it was decided to at least collate available information on the people who have been involved and the teaching and research programs developed since the first undergraduate subject in Economics was offered in 1901 - not least so as to provide some historical context for the 2002 External Review of the School of Economics. Since the previous External Review was fourteen years earlier, and because the pace of change has been far greater since the late 1980s than earlier in the century, more attention is given to that period than a balanced history would warrant. Descriptions of the many and varied contributions of the 100 or so faculty members employed over the century is not possible, but brief 12-line biographies are provided in Appendix 1 for the 40 per cent of those lecturers who became full Professors at Adelaide or elsewhere.

Thanks are due to the several research assistants who helped compile this information. Lona Fowder was instrumental in getting data compilation underway during an internship in the 2001-02 summer. Those who built on that beginning include Peta Anderson, John Breckenridge, Amy Stever, Liang Choon Wang and Wendy Zweck, with the help of staff of the University of Adelaide Archives and the University's Barr Smith Library including Les Howard and those in the Special Collections section. To all of these people, and to those past and present staff members whom we approached for views and information, we are extremely grateful.

While we have been careful to check all the facts presented, mistakes or omissions are inevitable given that the material has been drawn from a wide range of incomplete records. We apologise for any such errors, and welcome feedback so that the School's records can be corrected as and when they are being updated.

Kym Anderson

School of Economics and

Executive Director, CIES

Universityof Adelaide
Bernard O'Neil

Visiting Research Fellow

History Department

University of Adelaide 


\section{A chronology of the building of Economics at Adelaide*}

1901 Economics is offered by William Mitchell (Professor of English Language and Literature and of Mental and Moral Philosophy) for the first time as a core subject in the B.A. degree and an option in the LL.B. degree, with one LL.B. and two B.A. students graduating that year after passing the subject.

1902 The Advanced Certificate in Commerce is introduced, with six subjects including Economics and Commercial History (taught by Professor Mitchell) and Banking and Exchange.

1903 Joseph Fisher provides the University with an endowment to encourage economics and commercial education and a public lecture.

1904 The Department of History and Economics is formed within the newly created Faculty of Arts.

1908 The Advanced Certificate in Commerce is replaced with a longer Diploma in Commerce.

1912 William Mitchell's title is renamed Professor of Philosophy and Economics.

1916 Mitchell ceases economics teaching on becoming ViceChancellor.

1917 Herbert Heaton is appointed as the first full-time Lecturer in Economics.

1920 The two-part Economics subject formally becomes Economics I and Economics II, and a new subject, Economic History, is offered as an option in 2nd or 3rd year in the core offerings of the re-structured B.A.

1922 The Diploma in Economics and Political Science is introduced.

* Earlier dates of significance are 1874 (foundation of the University of Adelaide); 1876 (classes start in March); 1878 (a Political Economy subject is introduced in the B.A. and M.A. degrees, taught by Rev. William Fletcher, Hughes Professor of English Literature); and 1896 (Professor William Mitchell creates an optional M.A. field of Philosophy and Economics with an optional subject called Principles of Economics). 


\section{Chronology (continued)}

1929 Leslie Melville is appointed, at age 26, as Adelaide's first fulltime Professor of Economics; the Diploma in Economics and Political Science is replaced by a Diploma in Public Administration.

1930 The B.Ec. degree is introduced in December, following the promise of a bequest by George Gollin to support a Chair in Economics.

1931 Professor Melville resigns to become the first Economic Adviser in the Commonwealth Bank (later the Reserve Bank of Australia).

1935 Edward Shann is appointed Professor of Economics but dies mysteriously in May at the end of his first term of teaching.

1938 The Master of Economics degree is introduced.

1939 Keith Isles is appointed Professor of Economics; an Honours Economics degree is approved; John La Nauze introduces an economics subject for Bachelor of Agricultural Science students.

1945 Roma Williams, wife of Economics Lecturer Bruce (later Sir Bruce) Williams, becomes the first B.Ec.(Hons) graduate.

1946 Brian Tew is appointed Professor of Economics after Keith Isles' resignation the previous year; a new Department of Economics is formed within the Faculty of Arts by splitting its former Department of History and Economics.

1950 Peter Karmel is appointed Professor of Economics after Brian Tew's resignation the previous year; Lecturer Ron Hirst becomes the University's first M.Ec. graduate and is promoted to Reader.

1952 The Faculty of Economics is formed comprising the Department of Economics (still also a member of the Faculty of Arts) and a new Department of Commerce to be chaired by Russell Mathews on his appointment the following year; new enrolments in the Diploma in Commerce and the Diploma in Public Administration cease.

1953 Frank Jarrett, the University's first staff member with a Ph.D. from an American Land-Grant College, is appointed a Lecturer in Economics. 


\section{Chronology (continued)}

1959 Following the death of Mrs Gollin, the University receives the George Gollin bequest promised in 1930; Peter Karmel's professorship is named the George Gollin Chair in Economics.

1962 Professor Karmel is appointed Principal-Designate of the Bedford Park campus of the University; Harold Lydall is appointed to the George Gollin Chair; the journal Australian Economic Papers is launched by the Department with Hugh Hudson (later Deputy Premier of South Australia) as Editor and Geoff Harcourt as Assistant Editor.

1964 Eric Russell is promoted to Professor.

1966 On 1 July the Bedford Park campus becomes the independent Flinders University of South Australia with Peter Karmel as Vice-Chancellor; Flinders also attracts Keith Hancock (who becomes Professor of Economics there), Metoday Polasek, Eric Richards and Bob Wallace.

1967 Geoff Harcourt is promoted to a Personal Chair in Economics.

1968 Frank Jarrett takes over as George Gollin Professor of Economics after Harold Lydall's resignation the previous year.

1971 The Department's first Ph.D. student, Alistair Watson, graduates.

1977 Eric Russell dies of a heart attack; Ron Hirst retires as the longest-serving member of the Department up to that time (32 years).

1980 Cliff Walsh is appointed as a Professor and becomes Head of Department (but takes 2 years' leave from mid-1981 to be Senior Economic Advisor to Prime Minister Malcolm Fraser).

1982 Geoff Harcourt takes 3 years' leave without pay to take up an appointment at Cambridge; the Centre for South Australian Economic Studies is established by Adelaide and Flinders universities' departments of economics, with Norm Thomson as its first Director.

1985 Geoff Harcourt formally resigns so as to stay on at Cambridge.

1987 Cliff Walsh resigns to take up an appointment at the ANU.

1988 Frank Jarrett retires to Emeritus Professor status after 36 years at Adelaide (the longest-serving member of the Department 


\section{Chronology (continued)}

up to that time), leaving no Professors in the Department immediately after it has been externally reviewed.

1989 The Faculty of Economics becomes the Faculty of Economics and Commerce; the Centre for International Economic Studies (CIES) is established with Kym Anderson as its foundation Executive Director.

1990 The Chinese Economy Research Unit (CERU) is established by its foundation Co-Directors, Christopher Findlay and the Arts Faculty's Andrew Watson.

1991 Jonathan Pincus is appointed as the fourth George Gollin Professor and Head of Economics; Kym Anderson is promoted to a Personal Chair; the Commerce Department introduces a B.Com. degree; the Law School foreshadows that it will require its students to complete another degree before completing the LL.B.

1992 Richard Pomfret is appointed a Professor, returning the Department to three Chairs; Cliff Walsh returns from the ANU to become Executive Director and Professor of Economic Studies at the Centre for South Australian Economic Studies (soon to be renamed the SA Centre for Economic Studies, SACES).

1996 The departments of Economics and Commerce are re-named Schools.

1997 The Faculty of Economics and Commerce is absorbed into a larger Faculty of Performing Arts, Law, Architecture, Commerce and Economics (PALACE).

1999 Following the departure of its Co-Directors, the Chinese Economies Research Centre (previously CERU) is downsized to a program within the CIES.

2001 At the end of the year PALACE swaps Performing Arts for Education with the Arts Faculty and is renamed the Faculty of the Professions; the School of Economics prepares to be externally reviewed in 2002, 14 years after its previous review.

2003 The School accepts resignations from nine academic staff between late 2002 and early 2004. 



\section{Chapter 1}

\section{Birth and adolescence, 1901-1949}

\section{The Mitchell years}

Modern undergraduate economics teaching at the University of Adelaide began in 1901. The University was founded in late 1874 and first offered subjects in March 1876. Twenty-five years later a core Economics undergraduate subject was introduced, and that year saw the first two B.A. students and first LL.B. student graduate after completing the subject. Adelaide was thus a very early provider of tertiary economics education. It was preceded only by the University of Pennsylvania, which introduced a Bachelor of Science in Economics a decade earlier, and by the London School of Economics which was established in 1895. Simultaneously, a Faculty of Commerce was established at Birmingham University in 1901 (Turner 1904), followed in 1903 by Alfred Marshall's success in getting tripos status for economics at the University of Cambridge.

That is not to say there were no precursor subjects on offer at Adelaide prior to 1901. From 1878 lectures in Political Economy were offered to B.A. and M.A. students by the Reverend William Roby Fletcher (Hughes Professor of English Literature). While it is not clear how frequently these subjects were taught or how many students enrolled, numbers must have been small initially because in 1880 the library had just two books in the field (both by John Stuart Mill). The older universities of Sydney and Melbourne also introduced political economy subjects in the late 19th century. And they, like Adelaide, complemented those offerings with university extension courses in economics for non-degree students, whose evening classes continued until well into the 20 2 th century (Goodwin 
1966). Then in 1896 William Mitchell provided, within the field of Philosophy and Economics, a subject for M.A. students called Principles of Economics. But it was not until 1901 when the B.A. degree was reorganised that modern economics was made available to undergraduates.

Meanwhile, the South Australian business community was pressing also for the provision of commercial education at the tertiary level. Unlike the other Australian colonies, South Australia was established for commercial reasons rather than penal settlement. The colony came into being in 1836 through a joint venture between the British government and a private joint stock firm called the South Australian Company. Within three years a Chamber of Commerce had formed, and by 1869 a Chamber of Manufactures also was established (Viney 1936). These were the first such employer organisations in Australasia, and from the outset there was a strong awareness of the mutual spillovers between commercial and industrial activities locally and more broadly. In particular, their members recognised the need for tertiary education. Indeed the University of Adelaide's formation as early as 1874 was made possible largely through the financial bequest of Walter Watson Hughes, whose wealth emanated from his maritime trading interests and mining activities. The commercial successes of other notable South Australian identities, including Sir Thomas Elder, Peter Waite and Robert Barr Smith, also paid dividends in terms of generous gifts to the new University.

While practical business courses had been available for some time, ${ }^{1}$ more-advanced courses in such fields as accounting and

\footnotetext{
${ }^{1}$ One example dates from the arrival in Adelaide in May 1838 of Jacob Pitman and his family. Pitman's brother, Isaac, was the inventor of what became known as Pitman's shorthand. Jacob brought with him 100 copies of the justreleased 12-page booklet entitled Stenographic Soundhand, and within a few years shorthand classes were being advertised in Adelaide. Also, Roseworthy Agricultural College had a course on how to maintain farm records; and the University was involved at the secondary school level of commercial education through the curricula of the Public Examinations Board (Jones 1967).
} 
business law were sought by the business community. ${ }^{2}$ So, just one year after the Economics undergraduate subject began in 1901, Adelaide introduced Australia's first university course in commercial studies. It began as an Advanced Certificate in Commerce in 1902, but was upgraded to a Diploma in Commerce in 1908. ${ }^{3}$ One core subject in the course, Economics and Commercial History, was taught by Professor Mitchell, whose students attended his weekly lecture-tutorial in Economics for the B.A. and LL.B. The other five compulsory subjects were Accounting, Banking and Exchange, Business Practice, Commercial Law, and Commercial Geography and Technology.

Thus it was that Adelaide became, in 1901-02, one of the world's earliest providers of tertiary economics and commerce courses. This achievement was despite the fact that the University of Adelaide was still tiny: in 1900 it was endowed with just 5 acres of land (compared with more than 100 acres each for the universities of Sydney and Melbourne) and one building (now known as the Mitchell Building) to house its five schools, less than 20 lecturers, and 465 enrolled students not counting the Elder Conservatorium of Music (Duncan and Leonard 1973).

The focus on economics and commerce was given an early boost by a significant endowment in 1903 by the prominent Adelaide businessman Joseph Fisher. It came in the form of a perpetual gold medal for the top student in accounting each year, plus funds for a lecture to be delivered in alternate years and published. There was also an intention that the remuneration of 'lecturers, examiners, and professors' engaged in commerce education be enhanced. The fund was $£ 1000$, which is equivalent to around $\$ 500000$ in terms of 2002 spending power. At the time of the centenary of the University of Adelaide in the mid-1970s, the endowment was augmented by a further $\$ 10500$ by the 'Joseph

2 See the 17 January 1901 issue of Adelaide's leading newspaper at the time, the Register.

3 The Certificate course was an extension of the Elementary Commercial Examination that followed the Primary, Junior, Senior and Public Examinations in commercial subjects at schools. The University of Sydney established a similar commerce certificate in 1904 (Goodwin 1966, p. 554) and upgraded it to a diploma in 1906 (Groenewegen and McFarlane 1990, p. 42). 
Fisher Trustees'. The 49 Joseph Fisher Lectures that have been delivered since 1904 have been presented by a mixture of prominent economists in academia and government, senior politicians including two Prime Ministers, and influential Australian bankers and businessmen. Twelve of the past lecturers appear in Who's Who in Economics (Blaug 1999), 13 were knighted and one was awarded the Nobel Prize in Economics (James Meade). Most shared Joseph Fisher's interests in liberal markets and small, non-interventionist government. 4

As of 1901, Economics was one of eight full-scale subjects of which students were required to complete six towards their B.A. degree (in addition to other subjects or half-subjects). The other full subjects were English, French, German, Greek, Latin, and two courses in History. Initially economics was only to be taught in alternate years. The lecturer until 1916 was the formidable William Mitchell, who was the Hughes Professor of English Language and Literature and of Mental and Moral Philosophy before he went on to become the University's Vice-Chancellor from 1916 to 1942 and Chancellor from 1942 to 1948. In keeping with polymaths of the 19th century, during his teaching career Mitchell lectured in psychology, logic, ethics, the history and systematics of philosophy, English language and literature, education, anatomy and zoology, in addition to economics. ${ }^{5}$ Following the appointment of other specialists in the humanities, Mitchell's title was altered in 1912 to

4 As a contribution to the centenary of economics at Adelaide and of the Federation of Australia, the first 48 lectures were reprinted in a two-volume collection, together with brief biographies of each of the lecturers (Anderson 2001). See Table 22 for a list of the lectures and lecturers.

5 Mitchell once quipped that he occupied not a Chair but a sofa! In 1901 he was one of a staff of eight professors and twelve lecturers, plus eight teachers at the Elder Conservatorium of Music. The academic staff numbers had grown by one, seven and two respectively by 1902. It was the appointment of Robert Langton Douglas to the Chair in Modern History and English Language and Literature in 1900 that enabled Mitchell to devote attention to Economics. Other great teachers in the academy at that time included Reverend Walter Howchin, Professors William Bragg, Jethro Brown, (Sir) Douglas Mawson, Edward Rennie, (Sir) Edward Stirling, George Cockburn Henderson and Archibald Watson, several of whom also lectured as widely as Mitchell. 
Professor of Philosophy and Economics. So even though he is better recognised for his contributions to the University more widely, Mitchell was in effect the University's first Professor of Economics (albeit very much part-time).

In the first year that Economics was offered, Mitchell presented hour-long lectures at 5 p.m. on Mondays, Wednesdays and Fridays. Lecture days and times varied in subsequent years but were usually held in the evening or at night so that part-time students could attend after work.

The 1901 revision of the B.A. also established a fourth year of study, an Honours year, in which the field of 'History and Economics' could be studied. (M.A. students also could undertake a thesis in that subject area.) In order to undertake an Honours degree, candidates in History and Economics had to have passed English History, Modern European History, a foreign language (ancient or modern) and Economics among their six subjects for the Ordinary degree. Honours candidates in 'Mental and Moral Science' needed to have passed undergraduate Psychology, Logic, Ethics, History of Philosophy, Economics and another subject. M.A. degree candidates were to have a knowledge of 'Mental and Moral Philosophy' as in the Honours degree and of 'Elements of Economics' and a special subject called 'Principles of Economics' (being one of the six special subjects available since 1896 as part of the 'Philosophy and Economics' field). However, no-one enrolled for the B.A.(Hons), M.A. or M.A.(Hons) degrees in Economics before the courses were revised again for 1907 (Edgeloe 1992).

The course fees for Economics in 1901 were $£ 4 / 4 /-$ plus $£ 2 / 2$ / - for the examination. The Honours degree fees were, respectively, $£ 10 / 10 /-$ plus $£ 3 / 3 /-$. Consistent with today's practice of relatively high fees for an M.B.A., the fee for completing the Advanced Certificate in Commerce was $£ 14 / 12 / 6{ }^{6}$

In 1901 the students were examined on Mitchell's lectures plus Marshall's Economics of Industry and John Stuart Mill's Political

6 Since the average adult male wage today is about 230 times that in 1901, in nominal dollar terms, the fee of $£ 14 / 12 / 6$ is equivalent to $\$ 6800$ and hence well above the annual HECS fee that B.Ec. or B.Com. students are currently paying. 
Economy. In 1905 Gibbins's History of Commerce in Europe was added to the examination list. Honours students in Modern History and Economics were examined in six subjects of which Economics was one. The books on which they would be examined were Adam Smith's Wealth of Nations, Bastable's Public Finance and Cunningham's Growth of English Industry and Commerce. In Mitchell's time there was a limited range of modern economics and commerce books and few journals on those subjects.

Attending the University in 1901 were 257 undergraduates, 234 non-graduating students, and 288 students at the Elder Conservatorium of Music. How many people enrolled in Economics in its first year is not known, but 13 Arts students passed the two 3hour examinations in November 1901, including Dorothea Landon Poole who was thus the first female to pass. ${ }^{7}$ Three Law students also passed those exams in Economics that year followed by 11 more by 1910 . The first students to graduate after passing Economics were George Alfred Hancock and John Colville (Arts) and Richard William Bennett (Law) in 1901, the year that they sat the exam.

In 1904 the Faculty of Arts was established with several departments, one of which was the Department of History and Economics. That structure remained until 1946 when the Department of Economics was separated from History. A further separation took place in 1952, when a new Faculty of Economics was formed comprising two departments, one for Economics and one for Commerce.

7 Calendar of the University of Adelaide, 1902. At that time the relatively large number of women working in commercial enterprises made the pathway for female students in economics and commerce a little more acceptable than it otherwise might have been. An example was Constance Davey, who graduated from the University in 1915 with a B.A. Honours degree which included Economics. She had a distinguished career as a educational psychologist in the State Public Service and as a Lecturer and Research Fellow at the University. Her book, Children and their Law-makers: A Social Historical Survey of the Growth and Development from 1836 to 1950 of the South Australian Laws Relating to Children, was published in 1956, subsequent to her work at the University under a Federal grant for research into physical, biological and social sciences. She received an OBE in 1955. 
The Arts degree was revised again in 1906 and the new B.A. regulations from 1907 required a student to pass in six subjects over three years. Of the 16 subjects available, four had to be taken from a list of nine subjects including Economics. The History and Philosophy Honours students needed to pass Economics for their degree. The Ordinary and Honours M.A. degrees had similar requirements for the study of Economics. Barely a handful of students undertook an M.A. (seven in 1906) and how many took Economics is not known. At the undergraduate level, an indication of the place of Economics is that of the 388 undergraduates in 1907, there were 117 B.A. students of whom 17, including four women, passed Economics.

Meanwhile, the Advanced Certificate in Commerce was under the control of a University-appointed Board of Commercial Studies. From the outset Mitchell was on the Board along with the ViceChancellor William Barlow, Professor Bragg, a representative of the Institute of Accountants, and the president and vice-president of the Adelaide Chamber of Commerce among other business and commercial identities. In 1908 the Board had 16 members, whereas the business of the Faculty of Arts was managed by just 12 people. Four people served on both management committees.

The Board of Commercial Studies in 1908 brought in a Diploma in Commerce (Dip.Com.) to replace the Advanced Certificate. Certificate holders were able to upgrade to the diploma by sitting for the examination in Economics and Commercial History. Of the 11 people awarded a Dip.Com. in 1908, nine had upgraded their qualifications. In the next year another certificate holder did so followed by four more in 1910, the last year that this provision applied. Diploma graduates were entitled to use the postnominal letters 'ACUA' denoting their being an 'Associate in Commerce of the University of Adelaide' or a variant thereof. ${ }^{8}$

The inclusion of accounting as a subject in the certificate and the diploma reflected the needs of the local business community.

8 Diploma holders in other fields used the post-nominal letters AUA (Associate of the University of Adelaide). The ACUA was the most desired professional qualification for commercial teachers in South Australia (Jones 1967, p. 159). 
The Adelaide Society of Accountants, which formed in 1885, was the first professional accounting body in Australia. The South Australian Society of Accountants came into being in 1903. It and the Federal Institute of Accountants (SA Branch) merged to form the Australian Society of Accountants (SA Branch) in the 1920s. There was even an Accountant Students Society (SA Branch). Typifying the link between the University and the general community, as seen in the ongoing relationship with the Workers' Educational Association, in 1914 the Accountant Students Society enquired about using rooms on the campus. ${ }^{9}$

From 1909 Professor Mitchell's course in Economics for the diploma was the same as for the B.A., at least in terms of content. It involved 50 economics lectures over five terms with a 1-hour lecture each week at 7.30 p.m. The diploma students took the three terms of Economics Part I which dealt with the theory of values and its application to the consumption, the production, and the distribution of wealth, and with public policy' ${ }^{10}$ In the next year the diploma students would have two terms of lectures on 'public finance and an outline of economic history' as presented for the B.A. subject Economics Part II. The diploma courses were also available to nongraduating students. It was a popular course: 104 students were enrolled in the diploma in 1911, 126 in 1912 and 127 in 1913.

As well as Professor Mitchell, other lecturers included Bazett David Colvin (Accountancy and Business Practice), William Neill (Banking and Exchange) and Robert J.M. Clucas (Commercial Geography and Technology). ${ }^{11}$ Lecturers from the Faculty of Law presented the Commercial Law course. For example, Professor Salmond took the course for 1906 and Percy Johnstone B.A., LL.B. was the lecturer in 1910.

9 University of Adelaide file 153/1914.

10 University Calendar for 1909, p. 207.

11 Robert Clucas, the University Librarian from 1900 to 1930 after working for the colony's Education Department, had passed the Economics subject in 1901 and was appointed to lecture in Commerce in 1904 even though he did not gain his B.A. until 1908. He lectured in Economic Geography for 25 years. Clucas introduced both the Dewey decimal system and the card index catalogue system in place of the book catalogue for the library. 
William Ham was appointed a part-time Assistant Lecturer in 1913 to help Mitchell in teaching economics. Ham was a secondary school teacher who had obtained Division I passes in Economics. Elected a Fellow of the Royal Economic Society by 1921, Ham was also occasionally a non-graduating student in Arts subjects. His appointment ceased in 1922 but in the following year he qualified for the newly created Diploma in Economics and Political Science.

When Mitchell became Vice-Chancellor in 1916, the University used a small grant from the State government to appoint Herbert Heaton as the Director of Tutorial Classes that the University provided for the Workers' Educational Association and as the first full-time Lecturer in Economics in 1917 (Duncan and Leonard 1973, p.71). His interest in economic history paralleled that of Mitchell. Prior to his arrival in Adelaide, Heaton had followed his study for a B.A. degree at Leeds University (1911) with a stint as an Assistant Lecturer in Economics at Birmingham University (where he obtained a M.Com. in 1914) and as a Lecturer in History and Economics at the University of Tasmania from 1914. Among other things, he lectured weekly in Adelaide's diploma course where his subject was 'Industrial Practice'. ${ }^{12}$

\section{The inter-war years}

In the period immediately after World War I the University focused on expanding its interests in the sciences and technology. Thus agriculture, human physiology and pharmacology, dentistry and zoology received more attention than other subject areas. However, another restructuring of the B.A. degree in 1920 enabled Heaton to incorporate a stronger course in Economics. The two-part course that had evolved since 1901 formally became the subjects Economics I and II, and Economic History was instituted as a second- or a third-year subject (Edgeloe 1992). This stronger

12 Heaton was awarded a D.Litt. from Leeds University in 1921 for his publication on the history of Yorkshire's woollen and worsted industries (Bourke 1990, p. 59). 
emphasis on Economics meant that the two-year Dip.Com. was now quite distinct with 'Economics and Commercial History' becoming a one-year subject specifically for the diploma.

In addition to the part-time William Ham, Heaton was assisted by Dorothea Pavy (a D.Sc. from LSE) who was appointed as an Assistant Lecturer in Economics in 1922 for that one year. ${ }^{13}$ Ham, too, finished teaching that year and was succeeded in 1923 by Alexander Mackay, who took up a full-time position as Assistant Lecturer in Economics and Lecturer in Public Administration and Finance (a Dip.Com. subject introduced in 1921). Like Ham, Mackay had been a teacher in a State school system (from 1908 to 1916 in New South Wales). After interrupting his teaching career by a period of war service, he resumed his studies at the University of Sydney and graduated with first-class Honours in Economics in 1923.

Soon after, Heaton resigned in frustration at not being able to do more for Economics and Commerce at the University. To the dismay of many of his students, he did not return to teaching at the University after he took leave in 1924-25. After being passed over for promotion at Adelaide, he accepted a Chair of Economic and Political Science at Queen's University in Kingston, Canada (Bourke 1990, pp.63-64). Albeit indirectly, Heaton was the first example of an economist from the University entering the world stage: in 1927 he moved to a Chair at the University of Minnesota and 'built a

13 Emily Dorothea Proud graduated with a B.A. from Adelaide in 1906. Her sister, Katherine Lily Proud obtained a Dip.Com. in 1910 (the first female to graduate with a Dip.Com.). Dorothea (1885-1965) taught at Adelaide's Kyre (now Scotch) College for 5.5 years and in 1912 she became the first Catherine Helen Spence Scholar which was endowed to promote the study of sociology by women in South Australia. In 1913 she went to the London School of Economics where she published in 1916 a study on Welfare Work: Employer's Experiments for Improving Working Conditions in Factories, for which she received a D.Sc. Lloyd George, then Minister of Munitions, wrote the Preface for the book and in 1915 he asked her to assist him in organising the welfare section of the Ministry of Munitions. In 1917 she was awarded a CBE and she married Lieutenant Gordon Pavy. Returning to Adelaide, where a son (1920) and a daughter (1926) were born, she finished her part-time Law degree studies in 1928. She went into practice full-time with her husband but also lectured to social science students at the University (Mackinnon 1986). 
reputation as one of the most eminent economic historians in the English-speaking world' (Duncan and Leonard 1973, p. 71).

As well as founding and promoting the Adelaide University Commerce Students Association, Heaton worked hard to establish a branch of the Economic Society of Australia and New Zealand in Adelaide. The Society was established following a resolution at the Adelaide meeting of the Australian Association for the Advancement of Science in 1924. The South Australian Branch of the Society was founded at the University in 1925. The chief objectives of the Society were to advance economic knowledge through the publication of economic research and the discussion of economic problems. ${ }^{14}$ Four meetings with speakers were held annually. Students could join the Society at a reduced subscription rate.

Alexander Mackay remained as the principal lecturer of Economics for the B.A. degree and for the Diploma in Economics and Political Science (introduced in 1922). He also administered, until 1928, the tutorial classes for the Workers' Educational Association. He was assisted by part-time lecturers and tutors employed for teaching duties. These included Harold George Oliphant (1926-34) and Ernest Gordon Biaggini (1928-34). ${ }^{15}$

The University Council decided in December 1928 to create a Chair in Economics. This was in response to pressure from within and without for there to be more Chairs generally. ${ }^{16}$ The University's inability to finance new Chairs meant it did so by leaving the recently vacated Chair of Botany unfilled. The

14 Professor Melville was the Society's Treasurer in 1930, while the VicePresidents included Professors Sir William Mitchell and Keith (later Sir Keith) Hancock, businessmen such as A.E. Clarkson, E.W. (later Sir Edward) Holden and W.J. Young, and the State's Director of Mines, Dr Keith Ward. Melville was a foundation member in 1925, served as national President from 1939 to 1946, and was elected a Distinguished Fellow of the Society on his 90th birthday.

15 Edgeloe (1992). Absent in 1933, Oliphant was re-appointed a Tutor in Economics in 1934. He gained a Diploma in Economics and Political Science in 1925. His son, Sir Mark Oliphant, was the noted scientist, academic and Governor of South Australia (1971-76).

16 The Institute of Public Administration was among the bodies that had requested the State government to finance a Chair in economics (Duncan and Leonard 1973, p. 71). 
University then ran into problems when no suitable candidates applied. There are at least two stories about how the situation was resolved. One view is that the rising public servant tyro William Wainwright recommended to the Appointment Committee that it might consider a young recent graduate, Leslie (later Sir Leslie) Galfreid Melville, who had impressed his colleagues in South Australia's Audit Department. ${ }^{17}$ Another view is provided by the Chancellor, Sir George Murray, in his address to the University on 11 December 1929. In referring to the appointment of Melville, Murray noted that the original applicants had not had the desired overall grasp of the subject: 'The dilemma was solved for us by $\mathrm{Mr}$ L.G. Melville, the Public Actuary, offering himself as a candidate at the last moment ... he was exactly the type of man who was wanted. His appointment was warmly acclaimed extra et intra muros ...'.

One candidate, Professor A.G.B. Fisher, belatedly wanted to apply for the Chair of Economics early in 1929. The University's Registrar replied that the Council was 'very sorry that funds do not permit of our appointing a Professor with your high qualifications in addition to Mr. Melville, whose qualifications are of a more technical character' (Hogan 2002).

Melville was immediately engaged to take up the Chair at the end of the first term of 1929. He had already been a part-time Tutor in Economics (1924 and 1926) and a part-time Lecturer in Statistics for Commerce students (1925, 1927-28). The University's first fullyfledged Professor of Economics was not yet 27-years-old, making

17 Stretton (1991, p. 569). From 1916 Wainwright was a travelling inspector in the Audit Department but back in Adelaide by 1924 he was joined in that department by Melville who, at the age of 22, became the State's Public Actuary. About the time of the University advertising the Chair in Economics, Wainwright and Melville presented a paper, 'The economic effects of federation', to the Economic Society of Australia and New Zealand (published by the South Australian government in 1929). The WainwrightMelville connection was sustained, albeit briefly, with both being appointed to boards and committees including industrialisation and finance. Wainwright chaired the Advisory Committee on State Finance from 1930 and Melville served on the committee. Both were to become very powerful men in their respective spheres. Melville's life, incidentally, spanned almost exactly the period under review: he was born on 26 March 1902 and died on 30 April 2002 at 101 years of age (the same lifespan as Sir William Mitchell). 
him one of the youngest Economics professor in the world up to that time. A graduate of the University of Sydney where he had trained as an actuary, Melville was a Fellow of the Institute of Actuaries in both London and Australia.

The enthusiastic Professor advocated for the status of Economics to be upgraded through more advanced studies and for the creation of a Bachelor of Economics (B.Ec.) and a B.Ec. Honours degree. He was rebuffed on the latter but new regulations in December 1930 achieved the Ordinary Bachelor degree. The addition of a third-year unit in economics, a course in advanced statistics and actuarial mathematics, and new subjects such as accountancy and commercial law were some of the changes. The subjects for the Ordinary Bachelor degree were: First Year - French I, German I or Latin I; Economics I; Pure Mathematics I; Accountancy I; and Statistics I; Second Year - Economics II; Economic History; Psychology, Physics I or Geography18; and Commercial Law I; Third Year - Economics III; Statistics II; Actuarial Mathematics; and Commercial Practice. Students going on to the Honours degree through the B.A. had to 'devote a further year to the study of Economics, and ... perform such additional work as the Professor may prescribe'. ${ }^{19}$

Chancellor Sir George Murray's annual address in December 1930 announced that Melville's appointment as Professor and the new B.Ec. meant that 'we have realised a long-cherished ambition to confer degrees in Economics'. ${ }^{20}$ That address also contained the news that a bequest from George Gollin in London would, at some future point enable 'The George Gollin Professorship of Economics' to be established. George Gollin OBE promised that the University

18 Forms of economic or commercial geography had been taught since at least 1914 as part of the Diploma in Commerce, so the inclusion of the subject of Geography for the B.Ec. was not surprising. The death of Robert Clucas in 1930 opened the way for the employment then of Charles Albert Edward Fenner D.Sc., F.G.S. as the Lecturer in Geography in the 'Economics Department' as it was termed in the University Calendar for 1930. Fenner had been South Australia's first Superintendent of Technical Education in 1915 and was to become the State's Director of Education in 1939.

19 University Calendar for 1931, p. 187.

20 University Calendar for 1931, p. 366. 
would receive a sum of $£ 20000$ to endow a Chair in Economics when both he and his wife died. ${ }^{21}$ As it happened he did not die until 1946 and his wife lived until the late 1950s, so the money did not come to the University until 1959. By then it was insufficient to fully endow a Chair, but the University nonetheless attached George Gollin's name to the one Chair in Economics at that time (occupied by Peter Karmel). ${ }^{22}$

The lectures in Economics I for the B.Ec. were presented annually but the courses in Economics II and III were given in alternate years until a sufficient number of students had enrolled and justified the courses being run annually. Towards the end of the first decade of the B.Ec., there was an expectation that Economics III would be run in 1938 as well as 1939. Two students graduated in 1936 following on the heels of Gilbert Frederick Seaman, the first B.Ec. graduate in 1935; and the next year saw the first female B.Ec. graduate, Greta Ruby Crane.

Another outcome of Melville's appointment was the establishment of the Diploma in Public Administration, which had been advocated by those wanting to raise the quality of the Public Service. ${ }^{23}$ Melville also served on the Board of Commercial Studies.

Melville combined academic and public duties when he joined the special advisory council on State finance chaired by William Wainwright (and which also included W.J. Young and Les Hunkin). This followed the University acceding to the State government's requests in 1930 'to permit members of the professorial staff to aid them in solving some of the difficult problems by which the State is

21 University of Adelaide files 938/1961 and 72/1930. With his brother, Walter, George Gollin founded the trading firm of Gollin and Co. Pty Ltd in Adelaide in 1879. The company's operations expanded to Melbourne (1888), Sydney (1896), New Zealand (1900), London (1901-02) and, ultimately, throughout the world. George Gollin had moved to London prior to World War I.

22 Subsequent holders have been Harold Lydall (1962-67), Frank Jarrett (196888) and Jonathan Pincus (since 1991). The funds from this endowment remained with the University administrators, however, so the Department of Economics never received any financial benefit from the endowment.

23 University Calendar for 1930, p. 358. 
presently confronted'. ${ }^{24}$ Melville's contributions were so highly regarded that the State government asked him to continue on a committee preparing its submission to the Commonwealth's Public Accounts Committee that was inquiring into the disabilities incurred by the State since federation. The call to public duty was louder in 1931 when the Great Depression claimed Melville from the University through his appointment to the Commonwealth (later Reserve) Bank of Australia as its first Economic Adviser.

The recruitment and retention of staff at that time was not easy and the provision of resources and facilities was constrained by the Depression. A 10 per cent reduction in the State government grant to the University stimulated University staff to take a voluntary cut of $10 \%$ in their salaries. Despite that climate, attracting a Professor to replace Melville was not impossible. Alexander Mackay's disappointment at missing out on the professorship to Melville had already led to his falling out with the University: he took leave for 1929-30 and did not return in 1931 because the University would not create a sub-professorial post for him. In place of Melville and Mackay a recent University of Melbourne M.A. graduate, John Garland, served as Lecturer for 1932 through to August 1934 when he went to Cambridge to further his studies. Garland relied on the assistance of part-time tutors and assistants to sustain Melville's curriculum.

Garland's decision to leave, in part, may have been fuelled by an imminent change. In 1933 Edward Shann, the Professor of History and Economics at the University of Western Australia, had accepted the Chair at the University of Adelaide, although he then spent 1934 lecturing in Perth. ${ }^{25}$ Thus Garland was followed by John Andrew La Nauze. A Rhodes Scholar at Oxford's Balliol College from late 1931 to 1934, La Nauze was appointed full-time Assistant Lecturer in Economics. ${ }^{26}$ He had obtained first-class honours under

24 University Calendar for 1931, p. 366.

${ }^{25}$ Edward Owen Giblin Shann's significant publications established his name as an economist of the highest repute. He became the first economic consultant to an Australian bank - the Bank of New South Wales in 1930. His political involvement also helped to establish the importance of economists as advisers and consultants to developing economies.

26 University of Adelaide file 160/1934. 
Shann and also at Oxford where he read Politics, Philosophy and Economics. La Nauze was awarded a B.A. at the University of Adelaide in 1935 to complement the B.A. degrees he had obtained at Oxford and the University of Western Australia. La Nauze accepted the Adelaide post following Shann's encouragement: their families were neighbours in South Perth, and it was Shann who had convinced La Nauze to major in economics and literature as an undergraduate.

Shann arrived in time for first term teaching in 1935. Highly regarded as an economist ever since his student days, Shann had already held a temporary appointment as Acting Professor of Philosophy at the University of Adelaide when Professor Mitchell had taken leave in 1906 (presumably teaching or supervising economics in the 'off' year). He specialised in economic history. Indicative of his reputation, he had been involved, along with Professors Melville, Copland and Giblin, in preparing the Premiers' Plan for alleviating the distress caused by the Great Depression. Unfortunately, Shann's professorship was abruptly terminated through his mysterious death after only one term at Adelaide. Shann was found dead outside the window of his first-floor office of the Mitchell Building a half-hour after his final lecture early in the evening of 23 May 1935. The cause of his death was not determined, but he fractured his skull in the fall.

Shann's death was followed by another four-year hiatus before a new Professor of Economics was appointed. In the interim La Nauze maintained the three units of economics, the one of economic history and the courses in statistical methods for first-year students. He was helped greatly by very able part-time tutors and lecturers. These included Garnet Vere Portus, the Professor of Political Science and History, who taught the course in economic history from 1935 until his retirement in 1950. (Portus had taught the subject at the University of Sydney prior to coming to Adelaide in 1934.) One of the part-timers was Gilbert Seaman who had started in the Dip.Com. while at Adelaide Teachers' College. Melville advised him on the likelihood of the B.Ec. course eventuating and encouraged him to pursue the degree. Seaman thus became the University's first B.Ec. graduate -undertaking his studies while teaching full-time at Port Pirie High School! After 
passing his exams in 1935 Seaman was employed by the University as a part-time Tutor in Economics for three years, a Tutor in Statistics II, a Tutor and then a part-time Lecturer in Actuarial Mathematics (1936 and 1938; 1940-50) and Statistics I (1941, 194345). ${ }^{27}$ His employment as an evening lecturer terminated in 1950 when his course was discontinued by the new Professor. However, Melville's faith in his capabilities was vindicated in that Seaman's career in the State Public Service culminated in his becoming Under Treasurer.

Another economics teacher, Leslie Finlay Crisp, was to have a significant career outside economics. A B.A. student, Crisp was appointed a Tutor in Economics in 1938. ${ }^{28} \mathrm{He}$ resigned the Tinline Scholarship in history in that year when he also became the first of the University's students majoring in economics to become a Rhodes Scholar. He may have been influenced by La Nauze to pursue this direction. Both La Nauze and Crisp had articles on economic matters published in Phoenix (the renamed Adelaide University Magazine) in 1937 and 1938. In 1940 he was awarded the University's John L. Young Scholarship for Research enabling him to submit a thesis for his M.A. Crisp went on to a distinguished academic career in public administration and politics at the Australian National University where he held a professorship for many years.

The vacant Chair was filled in 1939 with the appointment of a one-time student of Professor (later Sir) Douglas Copland who had collaborated with Shann on publications. Replicating the appointment of Melville a decade earlier, the University's initial attempt to fill the Chair in 1937 failed. An apocryphal story is that Arthur Smithies, formerly of Tasmania and then at Harvard University, was a possible candidate for the Chair but that Copland advised against it on the reasoning that he would be of more value to Australian economics by being in the United States of America than at Adelaide. Another of the applicants was E. Roland Walker. Then a renewed expression of interest was received from Keith Sydney Isles, who had withdrawn his original application when he had secured a professorship at Swansea University College in Wales

27 University of Adelaide file 61/1936 and staff card.

28 University of Adelaide files 29/1938, 233/1938 and 206/1940. 
in 1937. It led to him receiving and accepting an offer in 1938 (although he did not take up the position in Adelaide until August 1939).

\section{The 1940s}

Isles had earned first-class Honours in Commerce from the University of Tasmania (under Copland) in 1924. He came to Adelaide to teach at St Peter's College in 1925. At the same time he won the Tinline Scholarship for history while studying part-time at the University of Adelaide. At Caius College, Cambridge he received first-class honours in the economics tripos in 1929, postgraduate awards and an M.Sc. (with a thesis on 'Wages Policy and the Price Level') in 1933. From 1931 to 1937 he lectured at the University of Edinburgh before accepting the Chair in Economics at Swansea in 1937.

As happened a decade earlier, the appointment of Professor Isles led to the departure of the incumbent economics lecturer. In 1939 La Nauze, who among his many tasks had even conducted a special course in Economics I for Bachelor of Agricultural Science students, resigned and went to the University of Sydney in 1940.29 His replacement as Assistant Lecturer was the charismatic Bruce (later Sir Bruce) Williams.

The University's regulations offered a Master of Economics degree from December 1938. Then the addition of an Honours level in Economics was achieved when new regulations were accepted in December 1939. The introduction of the Honours degree (initially without a thesis as a requirement) followed the adoption of the commercial aspects that Melville had wanted, and which had prevented Honours in Economics being offered previously. But the first B.Ec.(Hons) graduate was not until 1945 in Roma Williams, wife of the Lecturer Bruce Williams, while the first M.Ec. graduate was not until 1950, in the Lecturer in Economics Ron Hirst (Appendix 3, Tables 10 and 12).

Another former schoolteacher to make the transition to being a leader in the State Public Service was Alex Ramsay, a graduate of the University who was appointed a part-time Assistant Lecturer in

29 University of Adelaide files 85/1939 and 177/1939. 
Economics in 1943. In successive years he was then appointed a Tutor in Statistics and then a Lecturer in Statistics I. In 1945 he moved from teaching to the South Australian Housing Trust where he was the General Manager from 1949.

During World War II Professor Isles consulted to the Federal Treasury on war finance and compulsory war savings. He was absent for extended periods when he was Economic Adviser to the Commonwealth government's wartime Rationing Commission in Melbourne (September 1942 to February 1943) and a LieutenantColonel in the Directorate of Research in the Citizen's Military Force (1944). ${ }^{30}$ Meanwhile, at the University he also chaired the Board of Commercial Studies. The final year of World War II brought yet more significant changes to the teaching of Economics. Professor Isles was with the Control Commission in Germany when he resigned to take up the Chair of Economics at the University of Belfast in Northern Ireland.

As a consequence of Isles leaving, the career of Bruce Williams took a new direction. ${ }^{31}$ Even though Williams had secured a Rockefeller Fellowship in Chicago, Chancellor Sir William Mitchell tried to encourage him to return to Adelaide and to apply for the Chair. However, Williams felt he was too young for a chair and in any case he wanted to spend time in the UK. So he followed Isles' advise and successfully applied for a Senior Lecturer's position at Queen's University in Belfast. His securing of the position was consistent with Mitchell's expectation that many of the good academics would not remain long at Adelaide. He and his wife Roma left the University formally in 1946.

Though growing, the number of students at the University had remained small in the period before World War I: in 1914 the total student enrolment of 1044 included 409 undergraduates (of whom 195 were Arts students), 18 postgraduates, and 293 nongraduating students, plus 324 students at the Elder Conservatorium of Music. A decade later the enrolments had effectively doubled to 2018, with 311 of the 631 non-graduating students taking the

30 University of Adelaide file 206/1942; Sir Bruce Williams, personal communication, 15 October 2002.

31 Sir Bruce Williams, personal communication, 15 October 2002. 
Dip.Com. The Depression years impacted on the University's enrolments of course: in 1934 there were 2337 students, including 36 undergraduates in Economics and 396 taking the Dip.Com. (out of 903 non-graduating students). By 1944 the number of Economics undergraduates had risen to 57 (Duncan and Leonard 1973, pp.18790).

Up to 1945 there were never more than two full-time economics lecturers (and no full-time commerce lecturers) at the University at any time, and there was a Professor of Economics for less than a half of those first 45 years (see, Chart 1; Appendix 3, Tables 1-3). Those and numerous part-time tutors and assistant lecturers provided Economics to Arts and Law students from 1901 in parallel with Economics for the Diploma in Commerce students from 1902, the Diploma in Economics and Political Science between 1922 and 1929, and from 1930 the B.Ec. degree, with both Economics and Commerce majors, and the Diploma of Public Administration (see Table 15).

Following Professor Isles' departure in 1945, the University appointed Brian Tew as Professor of Economics. Tew, who had been in the Civil Service in the United Kingdom during the war, commenced duties in 1946. A notable achievement during his tenure was that Economics (including Commerce) separated from History in 1946 and formed a Department of Economics within the Faculty of Arts. Tew stayed only four years, before moving back to England to a professorship at the University of Nottingham.

In seeking a replacement for Tew, one of the outstanding candidates considered for the position was Heinz Arndt. However, Arndt was apparently rejected on the grounds that he had been a communist at the London School of Economics. ${ }^{32}$ Instead, Tew was replaced by a dynamic 28-year-old, Peter Karmel.

32 R.H. Wallace, personal communication, 16 August 2002; P. Karmel, personal communication, 2 October 2002. Arndt instead was appointed to the first Chair in Economics at what became the Australian National University in Canberra, where he had a very distinguished career for more than 50 years until his death in a car accident on the campus in May 2002, as he was driving to the funeral of Sir Leslie Melville where he was to give one of the eulogies. 


\section{Chapter 2}

\section{Growth and adaptation, 1950-2001}

For convenience, as with the first half-century of Economics at Adelaide, the second half also is split into three periods: until Peter Karmel became Vice-Chancellor of Flinders University in mid-1966; from then until Frank Jarrett's retirement in 1988, during which time Jarrett held the George Gollin Chair and was frequently Dean of the Faculty of Economics; and the period since then when Jonathan Pincus held the Gollin Chair and was Head of Economics for six of those years (1991-96, a term exceeded only by Karmel 1950-61 and Eric Russell 1967-76 - see Table 24).

\section{The Karmel et al. years}

Professor Peter Karmel's arrival in May 1950 began a major takeoff for Economics at Adelaide, aided by additional funds being made available by the Federal government for universities in the post-war era: 'From 1950 onwards the Department was amongst the foremost in the University in expansion of teaching and research activities and growth of tenured staff of distinction' (Edgeloe 1992, p.2). It was arguably the liveliest and best Economics Department in Australia by the early 1960s, with a growing number of staff establishing reputations nationally and ultimately internationally.

Within two years of his arrival, Professor Karmel had orchestrated the formation of a new Faculty of Economics with two separate departments, Economics (which also retained its membership in the Arts Faculty) and Commerce (to be headed by Russell Mathews on his appointment as a Reader in 1953). Karmel ceased admissions to the Diploma in Commerce and the Diploma in Public Administration so as to concentrate on the B.Ec., B.Ec.(Hons) and M.Ec. On staffing, Lecturer Ron Hirst became the University's first M.Ec. graduate in 1950, triggering his promotion to Reader that 
year, and five more lecturers were hired during Karmel's first three years. Milton Smith, John Grant, and Roger Opie were young Adelaide graduates, while Eric Russell and Frank Jarrett had returned from postgraduate education abroad.

Eric Russell was a student contemporary of Karmel's at the University of Melbourne where he had studied Arts and Commerce in the early 1940s. He had also completed a B.A. at King's College, Cambridge in 1947, and received an M.A. from Cambridge in 1959. He commenced teaching as a Senior Lecturer at the University of Adelaide in 1952 and was promoted to Reader in 1958 and to Professor in 1964. He also served as Chairman of the Department from 1967 to 1976. He died while playing squash soon after his return from a sabbatical in February 1977, at the early age of 55. 'He always insisted on taking a full teaching load - indeed, over the years his was always one of the heaviest - despite the very great weight of administrative and other university and, in later days, government activities that he carried at the same time ... In the 1950s and early 1960s Eric did great work for wage-earning groups, especially in helping Bob Hawke prepare his briefs for the ACTU's basic wage submissions. Eric was one of the first professional economists to go into the witness box in order to present evidence for the wage-earners' cause.' (Harcourt 1977a, pp469 and 471). Russell published very little, ${ }^{33}$ but his intellect together with his liberal social conscience ensured he had a great influence on other staff members and students at the University. Indeed several Professors have claimed that he should be ranked along with Trevor Swan as one of Australia's greatest-ever economists.

Frank Jarrett was the next non-Adelaide appointee. He had just completed doctoral studies in agricultural economics, and was the first appointee to the University with a Ph.D. from an American Land-Grant College, namely Iowa State. This caused some consternation. Some members of the University Council were so scathing of a Ph.D. from Iowa that they sought ways to have the

33 According to Harcourt (1977a,b), he published just two papers in economics journals (Russell 1965; Meade and Russell 1967). A third, his Presidential Address to the ANZAAS Congress in 1972, was published posthumously for him (Russell 1978). 
doctorate not recognised. Their proposed solution was to declare that only Ph.D. degrees with a Latin language requirement should be recognised. The issue faded within a few months, and Jarrett went on to lecture from 1953 to 1988 and thereby succeed Ron Hirst as the longest-serving member of the Department to that time. ${ }^{34} \mathrm{He}$ also spent several periods as Dean of the Faculty.

The next two appointments also were very influential, in Bob Wallace (Oxford background) in 1956 and Geoff Harcourt (Melbourne and Cambridge background) in 1958. In the decade he spent at Adelaide before transferring to Flinders University, Wallace played a major role in assisting Karmel attract several more outstanding scholars to the staff. The number of academic staff rose from a mere two or three in the 1940s, and five or six through most of the 1950s, to 18 by 1964 (Chart 2 and Tables 2 and 3). Many of the new staff were recruited from the University of Melbourne, where an unhappy atmosphere then prevailed in Economics. They were accommodated, along with the Arts Faculty proper, in the new 10storey Napier Building (built between 1958 and 1965 and named after Sir Mellis Napier, South Australia's Chief Justice and the Chancellor of the University from 1948 to 1961).

Geoff Harcourt was absent from Adelaide in the last three of what we have called the Karmel years, but that did not stop him from putting Adelaide on the map internationally. He was on leavewithout-pay at Cambridge, where his learning and publishing flourished (see Harcourt 2001, Ch. 1), and he built on that after he returned in 1967 (see next section).

This was also the period in which women joined the Economics lecturing staff (the only precedents being Dorethea Pavy as an Assistant Lecturer in 1922 and Roma Williams who was a Lecturer during 1946, pending her departure with husband Bruce to Northern Ireland). Maureen Brunt began her academic career at the University of Adelaide, where she was a Lecturer and Senior Lecturer from 1960 to 1964. She took leave without pay to spend time at Harvard (1964-66), and then became Australia's first female

34 With recent changes to the law regarding the statutory retirement age of 65 years, Jarrett has lost the service record to Brian Bentick who has been on the lecturing staff since 1965. 
Professor of Economics, at the new Monash University. The number of female lecturers remained at around 10 per cent of staff members until the 1990s, when it rose again to around 20 per cent (Chart 3).

Meanwhile, Commerce continued to rely almost exclusively on part-time teaching staff. The first full-time appointment was Russell Mathews in 1953 to a Readership following the formation in 1952 of the two departments, of Commerce and of Economics, which together made up the new Faculty of Economics. Mathews was promoted to a Chair in 1958 and was able to hire extra lecturers, but the total number of full-time lecturing staff in the Department of Commerce averaged only five in the 1960s and less than ten in the 1970s and 1980s (Chart 4). ${ }^{35}$ The introduction of a Master of Business Management degree in 1963 (the first of its kind in Australia), and its conversion to a Master of Business Administration in 1987, required some growth in staff numbers for that program (which in 1984 was transferred from the Department of Commerce to its own Graduate School of Management, renamed the Adelaide Graduate School of Business in 2002). ${ }^{36}$

On its formation, the Faculty of Economics decided to discontinue enrolments in the Diploma in Commerce and Diploma in Public Administration and to concentrate its efforts on the B.Ec. degree (Chart 5). Standards were set and kept high (resulting in high failure rates, which worried the University's administrators), and emphasis was also given to the B.Ec. (Hons) degree and a new M. Ec. degree. Enrolments in those research-oriented degrees remained modest in the 1950s and 1960s (Table 17), but the student quality was very high. Among the many to become stars were Richard Blandy (later Professor at Flinders University), who earned the top grade in every subject of his B.Ec. degree; Chris Caton, who became Chief Economist with Bankers Trust; Michael Codd, who became Head of the Department of the Prime Minister and Cabinet in Canberra; Malcolm Hill, who rose to Secretary of the Reserve Bank of Australia; John Menadue, who has been CEO of Qantas,

35 A Senior Lecturer in Economics from 1959 to 1964, Allan Barton, crossed over to Commerce as a Reader for 1965 and 1966.

36 See Table 23 for a list of the Deans and key support staff in the Faculty and its Departments/Schools since the early 1950s. 
Head of several key departments in Canberra and Australian Ambassador to Japan; Michael Porter who, after completing his Ph.D. at Stanford and developing the Kouri/Porter theory of exchange rate determination at the International Monetary Fund, went on to a professorship at Monash and then founded the Tasman Institute in Melbourne; and Deane Terrell who, following a period as a Rhodes Scholar at Oxford, rose to the positions of Professor, Dean, and then Vice-Chancellor at ANU.

It has often been pointed out that the quality of the staff attracted to Economics at Adelaide was extremely high throughout the Karmel years. Of the 32 appointments at Lecturer B level and above from 1950 to 1966, nearly half (15) became full Professors. However, high standards were not confined to that period. For example, of the 77 appointments at Lecturer B level and above from 1901 to 1995, more than half (at least 40) have become chaired Professors, seven have become long-serving Vice-Chancellors, seven are listed in the $3^{\text {rd }}$ edition of Who's Who in Economics (Blaug 1999), and at least 22 have been elected Fellows of the learned academies (Tables 5 and 6). ${ }^{37}$ And during the past 56 years ten students who have majored in Economics at Adelaide have gone to Oxford as Rhodes Scholars, five of them since 1991 (Table 14).

The endowment promised in 1930 by George Gollin, for a Chair in Economics when both he and his wife died, came to the University in 1959. While its $£ 20000$ was insufficient to fully endow a Chair by then, the University nonetheless attached George Gollin's name to the Chair occupied by Peter Karmel.

Another donation, to fund the Napier Birks Room for Economics and Commerce Statistics, came in 1954. ${ }^{38}$ The directors of Motors Ltd and its subsidiary Kingsway Ltd offered to donate $£ 2000$

37 Not shown in the tables is W. Max Corden, another to become an internationally renown professor. Corden was seconded from the University of Melbourne to Adelaide for several weeks in early 1958 because his father, while on a business trip to South Australia, had been admitted to the Royal Adelaide Hospital. Corden stayed until his father passed away. During that time he prepared for the ANZAAS Congress his seminal paper on tariffying import quotas and moving to a uniform tariff rate, and began work on what became his first Joseph Fisher Lecture (Corden 1958, 1966).

38 University of Adelaide file 35/1954. 
for establishing a library for Economics and Commerce staff and students in memory of Napier Kyffin Birks. Mr R.S. Pitcher, the Chairman of Motors Ltd, said Birks's colleagues on the boards decided on this gesture as a fitting memorial because 'Mr Birks, over a long period of years, took a most active interest in the commercial careers of the employees of his Companies and South Australian commerce students in general' ${ }^{39}$ In his response Professor Karmel reflected that a library per se would pose practical difficulties to the Department while not doing much more than duplicating the collection and services of the Barr Smith Library. He proposed furnishing a room for housing statistical materials and calculating machines as providing greater long-term benefit. The donors agreed, and a room in the Department was refurbished forthwith.

\section{The Jarrett et al. years}

The birth of Flinders University of South Australia on 1 July 1966 had a dramatic effect on Adelaide's Department of Economics. Not only did Professor Karmel become the Principal-Designate from 1962 (and Vice-Chancellor from July 1966), but numerous younger staff members also resigned to move to the new university's Bedford Park campus. The economists among them were Keith Hancock, Metoday (Matt) Polasek, Eric Richards and Bob Wallace. Perhaps because of this historical connection, relations between the two universities' economists remained friendly. Honours was taught jointly, as was the Masters by coursework; a jointly owned consulting group was established in 1982 and lives on as the South Australian Centre for Economic Studies (see below); a weekly combined seminar program was co-funded for much of the 1980s and 1990s; and the academic journal Australian Economic Papers (which celebrated in September 2002 its $40^{\text {th }}$ birthday as one

39 Birks, who had been the Chairman of Directors of Charles Birks and Co. Ltd, had founded Motors Ltd in 1911 and Kingsway Ltd in 1947. He had been the Chairman of Directors of both companies since their foundation. 
of Australia's two leading economics journals) ${ }^{40}$ has been edited jointly by staff in the two universities. There was also some specialisation between the two groups. For example, a 1967 proposal at Adelaide to form an Economic History Department was not taken up at Adelaide but was at Flinders, which was what attracted Eric Richards to move there.

Harold Lydall succeeded Peter Karmel as the George Gollin Professor in 1962, but shortly after the exodus to Flinders he too departed, ultimately to a Chair at East Anglia. Nonetheless, the Adelaide Department was left in good hands with three senior staff in Professors Eric Russell, Geoff Harcourt and (from 1968) Frank Jarrett in the George Gollin Chair.

Harcourt had been away from 1963 to 1966: a year of study leave, followed by an appointment to lecture in economics and politics at Cambridge and a Fellowship in Economics at Trinity Hall, Cambridge. During that time he built a formidable reputation as an economist, and in response the University of Adelaide had promoted him to a Readership in 1965 and to a Personal Chair in 1967 and insisted that he return for the beginning of that academic year. He remained a Professor at Adelaide until his resignation in 1985, although he spent the three preceding years on leave at Cambridge where he was a Lecturer in Economics and Politics and a Fellow of Jesus College. He was given Emeritus Professor status at Adelaide in 1988 and continued to promote the Department from Cambridge, where he was promoted to Reader in 1990. Outside of economics, his interest in the University's sporting life was wellknown around the campus, ${ }^{41}$ as was his passionate leadership of the

40 Australian Economic Papers was started in 1962 by its first editor, Hugh Hudson (later to become Deputy Premier of South Australia), with Geoff Harcourt as the assistant editor. Harcourt became joint editor in 1967 and served in that role for nearly 20 years, principally with Keith Hancock, Merv Lewis and Bob Wallace.

41 Professor Geoff Harcourt once claimed to be the only serving economics professor in the world to play Australian Rules football. In a match at Gaza Oval on a very wet day when the mud was inches thick and the players hard to identify and many turning up late, he coached the University team to a one-point victory. The sole University reserve player was not happy, however, as he spent the whole match on the bench. He complained 
anti-Vietnam War movement which included chairing the Campaign for Peace in Vietnam from 1970 to 1972.

This period saw dramatic growth in the B.Ec. program, from fewer than 40 graduates per year in the mid-1960s to a peak of 223 in 1991 (Chart 6 and Table 17). While the number of Lecturers B-E grew until the mid-1970s, it has been static or declining since then (Chart 2). As a result, the number of graduates per lecturer per year rose from 2.5 in the 1950s and 1960s to 3.5 in the 1970s and 5.0 in the 1980s. ${ }^{42}$ This was a direct result of the early-1970s initiative of the Federal Labor government led by Gough Whitlam to expand the facilities of tertiary education institutions. During this time the Department also taught Economics subjects dedicated to noneconomics students such as in the Faculty of Agricultural Science and, for a time, in the Centre for Environmental Studies. It also offered in the Faculty of Arts a popular terminal first-year subject in Social Economics (until 1986, when financial concerns were cited as the reason for withdrawing the subject).

This period also saw a greater professionalization of the lecturing staff. Up until 1950 the only economist who had a Ph.D. when appointed to Adelaide was Professor Tew, and until 1959 there were only two others (Karmel and Jarrett). Even between 1959 and 1971, when a total of 35 new staff joined the Department as Lecturers B and above, only 5 of them had Ph.D.s when appointed (one in seven). Since the early 1970s, however, more than 80 per cent of new staff have had a PhD on appointment and from the early 1990s that has been a requirement.

afterwards to the professor/coach about not getting a run. Harcourt explained to the upset player that he needed to keep a player in reserve in case the team suffered an injury (this was in the days before the interchange rule). When the upset reserve pointed out that the game had been played with one less than the full contingent of 18, Harcourt's quick-witted response was that the team only won because they had more room to manoeuvre (Bloch 1996, pp.15-16).

42 Lecturers include those in the Commerce Department, since Commerce graduates also received a B.Ec. until 1992; graduates include those receiving research degrees, who are given three times the weight of ordinary-degree graduates to reflect the more-intensive supervision required. 
The period from the mid-1960s to the mid-1980s also saw the emergence of Adelaide's Ph.D. program in Economics as well as modest growth in the numbers of its Masters and Honours graduates. ${ }^{43}$ Then, as in other Australian universities, the number of postgraduate Economics students declined substantially due to greatly increased employment opportunities for graduates with just Ordinary or Honours degrees. ${ }^{44}$ Hence in the 10 years to 1995 the Department graduated only two-thirds as many Masters and Ph.D. students as in the previous 10 years (Chart 9 and Table 17).

In the 1960s and 1970s the research concentrations of the Department were in such areas as wages policy, capital theory, money and banking, and agricultural economics, mostly as applied to Australia. The application of economics by some staff to specifically South Australian concerns led to the creation in 1982 of a Centre for South Australian Economic Studies. ${ }^{45}$ A national first, it was established jointly with Flinders University specifically to provide applied regional economic analyses of interest to the South Australian government and business (who shared in providing its initial funding of \$15000 per year). Adelaide's Norm Thomson and Trevor Mules were the first two Directors, with Graham Scott of Flinders as long-term Deputy (Table 19). In the mid-1980s the Centre produced two edited books, and it provided regular economics briefings to its corporate clients from April 1983 in addition to undertaking consultancies for them on a fee-for-service basis. Recent changes to the Centre's operations are mentioned in the next section below.

43 The spike of 26 Honours students in 1986 was the result of a mistake by the federal aid agency (the predecessor to AusAID) accidentally sending not one but all eleven Singapore scholarship holders that year to Adelaide instead of spreading them around to different Australian universities.

44 The Department's 1988 External Review report noted that very few of Adelaide's economics graduates were unemployed at the end of a financial year following their graduation in the period from 1977 to 1986, despite the high national unemployment rate during that decade.

45 The 1980s also saw the Department launch the Australian Centre for Experimental Economics, but as it attracted little funding and had a low profile it had quietly faded away by the time its main supporter, Alastair Fischer, moved to Cambridge in 1993. 
The external review of the Department in 1988 highlighted that, after the visionary leadership of Peter Karmel and the subsequent Professors, the Department had lacked 'consistent academic leadership' in the 1980s. Aside from the usual differences of views among senior staff, departmental governance had suffered through the Heads of Department serving too short a term or through their and other senior staff's involvement in other matters within and outside of the University. Lecturers and Senior Lecturers at that time considered they were shouldering an unfair proportion of responsibilities and intellectual leadership for which they were not compensated monetarily, or by way of promotion or assistance with their own work interests (Mayer et al. 1988, p.19).

This situation was exacerbated by Cliff Walsh's secondment to the Prime Minister's staff shortly after his appointment to a Chair in 1980, by Harcourt's absence from 1982 and resignation in 1985, by resignations from Lindner and Davis in 1986 and from Walsh and Lewis in 1987, and by Jarrett's retirement in 1988.

The Department was left not only virtually leaderless, but with indications that it might become primarily a service provider to other undergraduate degree programs then under review, particularly Law and Commerce. The late 1980s was also the beginning of a period - not yet ended - of a series of major Federal government reforms to higher education. These circumstances contributed to a further haemorrhaging of staff, this time of promising Lecturer Bs and Cs: following Chapman leaving in 1986 were Grossman and McTaggert in 1987, Nguyen and Ryland in 1989, and Anderson (on leave-without-pay) and Tyers in 1990. Derek Healey, one of the three Lecturer Ds at the time, also resigned in 1990. It was not until 1991 that the University appointed the first of the replacement Professors. He was J.J. Pincus, at the time Professor and Head of Economic History at Flinders University.

\section{The Pincus et al. years}

The appointment of Jonathan Pincus as the George Gollin Professor and Head of the Economics Department in 1991 coincided with three other pertinent developments in addition to the major 
reforms introduced by Federal Education Minister John Dawkins: the rapid rise in demand for commerce relative to economics undergraduate training; the (not-unrelated) decision by the Commerce Department to offer its own B.Com. degree program in competition with (and involving far fewer Economics subjects than) the B.Ec.; and a foreshadowed change of rules in the Law School that would require LL.B. students to qualify for graduation in another undergraduate degree before graduating in Law.

A clear reflection of the growth in demand for commerce relative to economics majors shows up in the numbers graduating since 1990 (Charts 6 and 7). Concomitantly, the number of commerce lecturers grew over the 1990s while the number in economics stagnated (compare Charts 2 and 4). ${ }^{46}$

Nonetheless, under Jonathan Pincus, staff morale and the number of senior members were quickly rebuilt. Pincus was instrumental in appointing Richard Pomfret, who arrived in January 1992 to the Chair that had been vacated by Cliff Walsh four years earlier; in attracting Walsh back from the ANU to a newly created (self-funded) position as Executive Director and Professor of Economic Studies at the Centre for South Australian Economic Studies (soon to be renamed the SA Centre for Economic Studies); and in encouraging Kym Anderson to return at the end of 1992 from his leave-without-pay position at the GATT Secretariat (now the World Trade Organisation) in Geneva. Since Anderson had been promoted to a Personal Chair in absentia in 1991, that returned the Department to the three Chairs it had enjoyed during most of the period from the mid-1960s to the mid-1980s. As well, in 1992 four Senior Lecturers (Christopher Findlay, Ian McLean, Sue Richardson and Colin Rogers) were promoted to join David Round, Tom Sheridan and Norm Thomson as Readers/ Associate Professors.

With these rapid developments the Department was spared the fate of some of the University's other departments such as History, and some of the other Australian Economics Departments,

46 The slowdown in demand for Economics places has not been genderspecific: the female proportion of B.Ec. admissions has remained in the 30-40 per cent range throughout the 1990s (up from barely 10 per cent in the 1970s - see Chart 8). 
which have become mere shadows of their former selves. But Pincus and his colleagues knew that the situation remained precarious, and that major innovations would be needed just to maintain, let alone increase, the current size of the Department (renamed School in 1996). The need for innovations was only partly related to the relative decline in demand for an undergraduate Economics major a decline that also occurred interstate and in other Western countries (Millmow 2002; Siegfried 2000). The other major influence was the program of higher education policy reforms in Canberra begun by Minister Dawkins in the late 1980s and continued in bursts through to the present.

Higher education reforms that were particularly pertinent to the Economics Department from the late 1980s included the introduction of significant tuition fees for domestic students (albeit still involving a large subsidy element and accompanied by a government income-contingent loan provision for delaying their payment), the substantial downsizing of scholarship funding and the charging of full tuition fees for students from overseas, the conversion of many former colleges of advanced education to universities (involving also numerous mergers to reduce the total number of institutions), and the substantial reduction in the proportion of the University of Adelaide's budget coming in the form of core grants from the Federal Government. These changes required university departments to become much more costconscious, demand-focused, market-driven, and subject to annual reporting of key performance indicators. In South Australia especially, where there was little growth in domestic student demand, much greater emphasis needed to be on exporting the University's services through attracting fee-paying international students and competitive research grants to compensate for the declining income from core government funding.

Welcoming the government's increased emphasis on student satisfaction and learning, the Economics Department embarked on innovations in the teaching of introductory economics, thereby gaining favourable attention. The Department also responded to quasi-market pressures by changing not only the B.Ec. but also its other offerings. One change was to introduce a Graduate Diploma to attract non-economics majors willing to pay (or able to attract a 
scholarship) for a professional training in Economics. The most successful part of that effort to date has been the winning, for four years in a row, of a contract to provide AusAID-funded places for 12 Chinese trade diplomats per year through the latter 1990s.

A more recent change was the School introducing a professional Applied Master's degree, mostly by coursework, and developing a M.Ec. degree by coursework and dissertation (as distinct from the M.Ec. thesis). Both new Masters are attracting a steady flow of fee-paying Economics graduates. As well, the Ph.D. program now has compulsory micro- and macro-economic and econometric coursework in the first year. This is an experimental first step towards an American-style doctorate. A targeted marketing campaign and the conversion of three Lecturer A (Senior Tutor) positions into ten teaching assistantships has helped to expand enrolments in these postgraduate programs since the late 1990s.

A third response involved introducing, in 1996, a Bachelor of Finance degree. As Chart 6 shows, that has compensated considerably for the slowdown in interest in the B.Ec. That program has been offered jointly by Economics, Commerce and Mathematics.

A fourth reform has been to facilitate enrolment in another degree along with the B.Ec. The student response to making that double-degree option more widely available since the mid-1990s has been dramatic (Chart 10). For B.Ec. students, the most common joint degree has been Finance, followed by Law and then Engineering, with Commerce and Arts slightly less popular (Chart 11). Looking at it from the viewpoint of the other degree, Economics is the most popular choice for B.Fin. students, and with Finance it is equally as popular for B.Eng. students as Commerce (Charts 12 and 16). For B.Com. and B.A. students, Law is by far the dominant joint degree, with Economics the choice for only a small minority (Charts 13 and 15). And for LL.B. students, who since 1995 have not been allowed to graduate in Law without having another undergraduate degree, the dominant choice was Arts initially but Commerce is becoming more popular as are both Economics and Finance (from much lower bases - see Chart 14).

Another University response has been to introduce brackets to the names of degrees, following the attempt by newer universities to 
attract more school-leavers. Commerce now offer 'named' B.Com. degrees in all of its fields (accounting, corporate finance, international business, management and marketing), but in Economics this has only been done so far to accommodate the transfer of a degree program in international agribusiness from the Roseworthy Campus to the School of Economics. Related to that merger of Roseworthy Agricultural College with the University has been the emergence of a Bachelor of Wine Marketing at the Waite Campus, for which the standard first-year subjects taught by the School of Economics (microeconomics, macroeconomics and data analysis) are compulsory.

On the research side, the Department's response to its changing environment has included the development of specialised research centres (see below).

Notwithstanding all these responses to changes in the demand for and regulation of Economics teaching and research services, career options for academics within the Department have been limited. This is evident in the lack of growth in Professor and Associate Professor positions since the mid-1960s, requiring most of the Department's promising young recruits to leave Adelaide to advance their careers. Hence other universities rather than Adelaide are reaping the rewards of the early investments in the teaching and research capabilities of those lecturers. ${ }^{47}$

Economics departments of other Australian universities, particularly the older established (Go8) ones, have managed since the late 1980s through raising the number of staff in total and the proportions of Professors and Associate Professors. As a result, Adelaide's School of Economics is badly out of line in staff profile and student-staff ratios: Adelaide now has the smallest number of Economics lecturing staff and the lowest proportion of staff at senior levels (less than half the average of comparable Economics Departments - see Table 24).

47 Four of the School's 40 Lecturer B-E appointments to 1995 who became Professors did so through promotion at Adelaide (Jarrett, Russell, Harcourt and Anderson) and another seven were appointed as Professors at Adelaide over that period. The remaining 29 went elsewhere to reach professorial rank. 
The number of students per Economics lecturer (full-time equivalent Lecturers A-E) averaged 15 in the 1970s, 17 in the 1980s, 19 in the 1990s, 23 in 2000-02, and prospectively 31 by 2005 if there are no net additions to the staff (Rogers 2002). The number of graduates per Economics and Commerce lecturer, which had risen from 2.5 in the 1950s and 1960s to 5.0 in the 1980s, rose to 7.5 in the first half of the 1990s and to 12.4 in the six years to 2003. This has happened despite growth in numbers of students (including full fee-payers) large enough to finance more staff at Adelaide: the University felt the need to divert those increased earnings to poorer-performing parts of the University. The School has been able to retain some Emeritus Professors and attract some high-quality Adjunct Professors, Post-Doctoral Fellows and Affiliates as low-cost ways to improve the research and teaching environment (Tables 4 , 20 and 21), but they are not close substitutes for additional permanent full-time staff.

Despite these handicaps, the School has done well in terms of some key performance indicators in the past dozen or so years, compared at least with earlier periods and with other departments at Adelaide. The above trend in student/staff ratios - a several-fold increase in the annual number of graduates per staff member compared with the 1960s and 1970s - suggests a likely improvement in teaching productivity, even bearing in mind the need to adjust raw quantitative indicators for any deterioration in quality (as a result, for example, of increases in the size of tutorial classes).

There has also been an improvement in the quantity of research training. Economics research training began at Adelaide with the first Honours graduate in 1945 (Roma Williams) and the first Masters graudate in 1950 (Ron Hirst). ${ }^{48}$ But it was not until 1971

48 A precursor was a thesis by Henry Brown in 1937 for the John L. Young Scholarship. In 1918 John Harvey Finlayson bequeathed £200 for a John Lorenzo Young Scholarship. The scholarship in Political Economy or a related subject was valued at $£ 30$, the investment income when it was first offered. It was to be offered every three years or so thereafter while the investment amounted to $£ 30$. 'Political Economy' was extended to include 'present or past students of the University who have passed in a degree course the subject of Economics, or a subject judged by the Faculty of Arts to be cognate to Economics, not more than six years before the date of the 
that the first Ph.D. students graduated (Alistair Watson, who began his doctorate in 1965, and Kyoko Sheridan who started a couple of years later). Since then the numbers graduating each year have been 10-15 for Honours and 2-4 for postgraduates until the mid-1990s (Chart 9 and Tables 7 to 12). Since then there has been some growth in the number of Ph.D. completions, averaging 2.9 per year since 1996 compared with only 0.9 in the previous 25 years, and Masters completions, averaging 1.9 per year since 1996 compared with around 1.3 per year during the previous 25 years and 1.0 per year in the 1950s and 1960s (Chart 9 and Table 17).

Another research training performance indicator (again subject to adjustment for quality of learning) is the average and median number of months taken to complete a research degree. That has been dropping steadily for both Masters and Ph.D. degrees: from the high 50s and more in the 1960s to the low 40s for Ph.Ds and the low 30s for research Masters students in the 1990s (Table 25).

The applied interests and gradual internationalisation of both staff and research students are reflected in the thesis topics chosen. More than three-quarters of the Ph.D. theses and all but $5 \%$ of the Masters theses to date have been on applied rather than theoretical topics. Of those applied theses, prior to 1987 all the Ph.D. theses and all but three of the Masters were applied to Australian topics. Since then, by contrast, half the Ph.D. theses and two-thirds of the Masters have been applied to other countries or to broader international issues (Tables 8 and 10). A similar if less pronounced trend is evident in Honours thesis topics (Table 12). Evidently globalisation is affecting the School's research training program, just as it is affecting the research activities of the staff themselves (see below and the working papers listed in Tables 26-29).

The Centre for South Australian Economic Studies (established in 1982 and re-named in February 1993 the South

award'. Scholarship holders were required to submit a thesis on political economy or economics within 12 months of receiving the award. The first two recipients of the scholarship were Sarah Elizabeth Jackson M.A. (1918) and Thomas Schulz Opie (1921), both of whom pursued psychology as their interest. Henry Brown was the first to submit a mainstream economics thesis. 
Australian Centre for Economic Studies, SACES) has concentrated on providing regular economics briefings to its corporate clients in Adelaide and undertaking consultancies for them and others (including interstate and recently in New Zealand, China and Indonesia) on a fee-for-service basis. Its level of activities and fulltime staffing grew rapidly after Professor Cliff Walsh was appointed its Executive Director in July 1992, but diminished for a while after he stepped down for health reasons in the latter 1990s (Hancock et al. 2000). The Centre relies mainly on its own full-time staff (fully paid for from consulting income), and in recent years it has only occasionally involved economics lecturers of the two universities as casual part-time consultants. SACES income is substantial (in excess of $\$ 0.5$ million in both 2001 and 2002) and attracts supplementary funding from the Federal government under the Research Infrastructure Block Grants and Institutional Grants Scheme (RIBG and IGS). SACES incurred a considerable debt during its period of lower revenue in the late 1990s but, following an external review (Hancock et al. 2000), it has become profitable again and in 2002 paid a dividend of $\$ 50000$ to each of Adelaide and Flinders universities. To date it has contributed little in terms of higherdegree research training or attracting nationally competitive research grants, but it does provide an important public face for the two universities particularly through its regular briefings to clients on the state of the economy.

A second centre of specialisation was established in 1989, the Centre for International Economic Studies (CIES). It was modelled on Stockholm's Institute for International Economic Studies where its founder, Kym Anderson, spent a sabbatical year in 1988. Without drawing much financial support from the School or University it has managed to fund a part-time Executive Assistant and (from 1996) a part-time Deputy Director with funds from a series of ARC Large Grants, even-larger grants from the government's Australian Centre for International Agricultural Research (1997-2002) and from AusAID.

A third centre was established in 1990. Initially it was called the China Economy Research Unit but in 1996 was retitled the Chinese Economies Research Centre (or CERC). Co-directed by its founders, Christopher Findlay and the Arts Faculty's Andrew 
Watson, CERC was extraordinarily successful in obtaining grants, in providing higher-degree supervision, and in publishing working papers and books. With the departure of the two Co-Directors in 1999 (Findlay to a Chair at the ANU, Watson to head the Ford Foundation office in Beijing) and of their last post-doctoral fellows, the School was left with insufficient staff focusing on China to keep CERC going so it was absorbed by and became a program area within CIES.

A fourth centre was the Centre for Economics Education, established in the early 1990s by Judy Cowie with strong support from Christopher Findlay. It too was extraordinarily successful in attracting grants to do research on the teaching of undergraduate economics. Its high-profile success was heavily dependent on Cowie's energy and enthusiasm, however, so when she left Adelaide in 1996 it faded away.

The various Centres' publication and dissemination programs have raised the domestic and international profile of the School by adding several-fold to the annual number of working papers disseminated by the Department: CERC produced an annual average of ten during its decade of operation (Table 29) and CIES has produced an annual average of almost 40 since the Centre came into being 14 years ago (Table 28). ${ }^{49}$ As well, SACES has generated, in addition to commercial-in-confidence papers and briefing reports for its member clients, two series of publicly available papers and several monographs (Table 27). During the past few years all CIES working papers have been freely downloadable from the Centre's website. Since introducing that capability, the site's hit count has averaged more than 600 per month. ${ }^{50}$

49 Details of the publications by CIES and CERC associates are available in CIES $(1990,2002)$ and at the CIES website at http:/ / www.adelaide.edu. au/cies. In the past year or two the rest of the School's publications have been added to that database and are now listed for each staff member at http:/ / www.adelaide.edu.au/ econ/publications.

50 Additions to the CIES working paper series are highlighted each four months via the CIES Newsletter that is disseminated (in recent years via email) to more than 1000 recipients who include people in government, business, think-tanks and international agencies as well as economic and policy 
While the School's authors and editors normally seek commercial publishers for books, some material produced for conferences, consultancies or executive training courses is perceived to have a market too small to be able to cover the expected fixed costs of commercial book production and marketing. SACES and CIES have found a way to turn such manuscripts into printed volumes at low cost, however. So rather than have that material not see the light of day, they have put them between covers and advertised them through their websites and the CIES Newsletter. Such has been the success of that approach that several publishers have subsequently sought co-publishing rights with CIES (see the list in the final part of Table 28). ${ }^{51}$

Publication quality is, of course, a much more important performance criterion than just the quantity of papers and books produced. The vast majority of at least CIES Discussion and Seminar Papers have been subequently published, albeit with only a few ending up in the top economics journals. ${ }^{52}$

The number of publications per staff member by the School of Economics as a whole may appear to be low compared with the rest of the University (particularly the sciences). In 2001, for example, the number of DEST publications points per staff member was 0.94 in Economics (or 0.62 including Lecturer A and SACES staff) ${ }^{53}$, less

analysts in research institutes and universities around the world. Its working papers are also included in the Social Sciences Research Network listings.

51 The most notable example is the Dictionary of Trade Policy Terms by CIES Affiliate Walter Goode. For some years it has been the top-selling book in the WTO Secretariat's Bookstore in Geneva, is now in its third edition, has been translated and commercially published in three Asian languages, and is also being sold in the thousands throughout South Asia, in a lower-cost English language version, under an agreement between CIES and a Pakistani law and publishing firm. The $4^{\text {th }}$ edition, forthcoming in 2003, is being copublished by Cambridge University Press for the World Trade Organization.

52 Details are provided on the CIES website and in CIES (2001). Unfortunately records have not been kept of whether/where School and CERC working papers have been subsequently published.

53 DEST points refer to the federal Department of Education, Science and Technology's count of eligible publications. The count is compiled by universities each year as part of their annual performance evaluation, and is subject to random auditing by DEST. 
than half the University average of 1.9; and the proportion of staff generating DEST publication points was 24 per cent compared with the University average of 54 per cent (see the spreadsheets prepared for University of Adelaide 2002). However, it is true for economics and the social sciences generally in all universities that they publish a smaller number of papers than the other sciences, so a more relevant comparison is with other economics schools.

There are now several studies that compare Adelaide's publication performance with that of other Economics Departments in Australia. The Harris (1988 and 1990) weighted count of several types of publications rates Adelaide as tenth in 1974-83 and fourth in 1984-88 in terms of total publications, and second and fifth in terms of works cited per capita and citations per capita as of 198687. A more-recent count by Pomfret and Wang (2002) of the number of publications just in the top 88 journals ${ }^{54}$ ranks Adelaide eighth in terms of total articles during 1990-2001 and fifth in terms of articles per capita during 1995-2002.

Such counts only measure the quantity of publications, but other studies try to take quality into account also, at least for journal articles. Sinha and Macri (2001), for example, show that by the Towe and Wright (1995) journal count per capita criterion, Adelaide from 1988 to 2000 has done moderately well in $4^{\text {th }}$ ranked journals $\left(6^{\text {th }}\right.$ in Australia) but less well in the higher-ranked journals (between 10 and $\left.12^{\text {th }}\right) .{ }^{55}$ Adelaide has also done less well by the Mason, Steagall and Fabritius (1997) journal perception-based criterion (ranked 12 on a per capita basis) and the Laband and Piette (1994) citationbased criterion (14th on a per capita basis). When the period is split into two, Adelaide moves up two to four rankings for the period from 1994 compared with the 1988-93 period. It needs to be kept in mind, however, that theory journals tend to be more-highly ranked by the academic profession than applied and policy focused journals. If a ranking were to be made by professional economists

54 The $88^{\text {th }}$-ranked journal is Australia's Economic Record.

$551^{\text {st }}, 2^{\text {nd }}$, and $3^{\text {rd }}$ ranked journals are what the authors (following Diamond 1989) consider to be the top 12, the next 23, and the next 44 best economics journals in the CD-ROM of the AEA's Journal of Economic Literature, while $4^{\text {th }}$-ranked journals are those ranked from 80 to 400 in that database. 
outside academia based on readership, Adelaide would look much better because its economists have always been more applied than the older universities in the eastern States.

As for publishing books with academic presses, some Adelaide staff have performed well above the national average. However, comparable data for the average of all staff in each Australian economics department are not available. (Unfortunately also not available is a comprehensive list of actual publications by each staff member each year they were at Adelaide, except for the most recent years.) Noteworthy books from the 1970s include Harcourt's review of controversies in capital theory and the Pincus study of the political economy of American tariff policy formation (Harcourt 1972; Pincus 1977). More-recent books of note have been in the development and trade areas, particularly by Richard Pomfret and Kym Anderson. As well, the introductory Parkin textbook adapted by Christopher Findlay and Doug McTaggart became the biggest-selling economics book in Australasia in the 1990s, capturing as much as half the target market (McTaggart, Findlay and Parkin 1999).

It is also true that Adelaide's applied economists would rank above average nationally in terms of contributing to policy focused conferences and seminars both in Australia and internationally. Many of the papers for such conferences have been included in commercially published conference proceedings volumes. Public service contributions have also included periods of staff secondment to or part-time work for national and international agencies. This continues the Department's tradition of earlier decades of applied analysis on Australian policy issues, and extends it to the global arena. Contributors in the past decade include (in alphabetical order) Anderson with the GATT Secretariat, WTO, OECD and World Bank; Findlay with the PECC and APEC communities throughout the Asia-Pacific region; Pincus and Richardson with Australia's Productivity Commission; Pomfret with the United Nations, World Bank and Asian Development Bank; and Round with Australia's Trade Practices Commission and related/successor agencies.

Last but by no means least, mention should be made of the School's co-editing with Flinders University of the journal 
Australian Economic Papers since 1962. The editorial efforts of Pincus and the current Editor, Richard Damania, have raised the journal's international profile substantially in recent years, not least by allowing it to be commercially published through Blackwell in Oxford from 1998.56 Currently being sought is an International Editorial Board, to enhance the journal further and to make it eligible for inclusion in the Social Sciences Citation Index database.

56 The December 2002 issue, for example, included a Comment by Nobel Laureate Milton Friedman. 


\section{Chapter 3}

\section{Prospects for the next century}

The Economics discipline at the University of Adelaide has a distinguished 100-year history of which the University and the State of South Australia can be proud. Very few other departments, of any discipline in Australian universities, could claim to have a majority of its lecturer appointments rising to full Professor status over a period as long as 1901 to 1995. Nor would many other university departments be able to say they have had five of their graduates win Rhodes Scholarships in the past 12 years (Table 14). While teaching and research productivity is more difficult to gauge, because changes in quality matter, the growth in the number of graduates per Economics and Commerce lecturer per year has been impressive: from 2.5 in the 1950s and 1960s to 5.0 in the 1980s, 7.5 in the first half of the 1990s, and 12.4 in the six years to 2003.

The period since the Dawkins' reforms to higher education began in the late 1980s has been one of rapid change for Economics at Adelaide, as it has for other departments. One indicator of that is the number of changes (three) in the name and composition of the faculty in which Economics is housed since 1988 (Table 23). Another indicator is the growth in the number of awards available. For over five decades, Economics was provided via just the B.A. and M.A. From 1930 the B.Ec. then served Economics and Commerce for another six decades, supplemented by three professional diplomas until 1952 and by the M.Ec. from 1938, the B.Ec.(Hons) from 1939 and the Ph.D. from 1965. In the past 15 years, by contrast, the University has introduced no less than 20 additional awards in Economics and Commerce (Table 15).

The recent rapid pace of change shows no sign of slowing. Economics at Adelaide will need to continue to respond to 
challenges and grasp opportunities as and when they appear (just as it did during the period of national higher education growth in the 1960s). Crises there have been, as in the late 1980s when all three Chairs were vacated and the Department was left virtually leaderless at a time of extreme financial stringency for the University and major reforms in national higher education policy. But renewal was possible in the early 1990s under Jonathan Pincus' leadership, and hopefully it will be again in the early 21st century. ${ }^{57}$

With the recent conversion at Flinders University of their B.Ec. to an international business degree, and with the University of South Australia also focusing on a Bachelor of Business degree, Adelaide is now the only provider of mainstream economics training in South Australia. That reduced supply capacity helps to offset the reduced domestic demand for economics courses, but additional strategies nonetheless will be needed just to maintain the School's teaching, research and research training performance, let alone restore Adelaide to its former position as one of the top Schools of Economics in the southern hemisphere - as it arguably was 40 years ago.

In submissions to the School of Economics External Review Committee in August 2002, and in an earlier review of the School's activities over the 1990s, numerous strategies to rejuvenate the School were suggested. ${ }^{58}$ They focus particularly on better marketing to attract more fee-paying students, greater incentives for staff to seek research grants and to publish in reputable places, and further revisions of course structures including in response to the rising value of students' time.

A key area that has been neglected in the past, however, is attracting funds from alumni. The University recently re-designed

57 A major opportunity for that has arisen following the resignation of nine academic staff in the twelve months to early 2004. They included (see end of Table 2) four Lecturer B's, two C's, one D, one ARC-funded CIES Research Fellow, and Professor Jonathan Pincus (who took up the position of Research Director at the Productivity Commission in Melbourne). As well, Professor Kym Anderson has taken extended leave to spend a period as Lead Economist (Trade Policy) in the Development Research Group of the World Bank in Washington DC).

58 Pomfret (1999); Pincus (2002); Anderson (2002); Rogers (2002). 
its Alumni Office to make it easier for graduates to form an Alumni Chapter for their discipline area. Moves are under way to establish an Economics Chapter following the School's Centenary Dinner at the National Wine Centre on 30 September 2002. With that Chapter in place, the scope for seeking endowments and other donations to supplement the School's earning will be enhanced considerably. The declining share of the University's funds coming as block grants from the Federal government (currently less than 40 per cent) ensures alumni and other private-sector contributions will be essential if the School of Economics is to thrive during its second century. 


\section{References}

Anderson, K. (ed.) (2001), Australia's Economy and its International Context: the Joseph Fisher Lectures, Volume I (1904-1948) and Volume II (1950-2001), Adelaide: Centre for International Economic Studies.

Anderson, K. (2002), 'Strengthening Adelaide's Research Performance in Economics', Submission to the 2002 External Review of the School of Economics, University of Adelaide, August.

Blaug, M. (ed.) (1999), Who's Who in Economics (3rd ed.), London: Edward Elgar.

Bloch, F. (1996), A History of the South Australian Amateur Football League 1911-1994, North Adelaide: South Australian Amateur Football League.

Bourke, H. (1990), 'Herbert Heaton and the Foundation of Economics at the University of Adelaide, 1917-1929' in F.B. Smith and P. Crichton (eds), Ideas for Histories of Universities in Australia, Canberra: Research School of Social Sciences, ANU.

Brown, H. (1937), 'The Copper Industry of South Australia: An Economic Study', unpublished John L. Young Scholarship thesis, University of Adelaide.

CIES (1990), List of Publications by CIES Researchers During the 1980s, Adelaide: Centre for International Economic Studies.

CIES (2002), List of Publications by CIES Researchers, 1989 to 2001, Adelaide: Centre for International Economic Studies, March.

Corden, W.M. (1958), 'Import Restrictions and Tariffs: A New Look at Australian Policy', Economic Record 34(69): 331-46. (Reprinted in his The Road to Reform: Essays on Australian Economic Policy, Melbourne: Addison-Wesley, 1997.)

Corden, W.M. (1967), 'Australian Tariff Policy', 32nd Joseph Fisher Lecture, University of Adelaide. (Reprinted in Australian Economic Papers 6: 131-54, December 1967 and as Ch. 32 in Anderson (2001).) 
Diamond, A.M. (1989), 'The Core Journals of Economics', Current Contents 2: 4-11, January.

Duncan, W.G.K. and R.A. Leonard (1973), The University of Adelaide, 1874-1974, Adelaide: Rigby Ltd.

Edgeloe, V.A. (1992), 'The Teaching of Economics in the University of Adelaide 1900-1975: A Brief History', mimeo, Adelaide: University of Adelaide.

Fleming, G.A. (1995), 'The Early Years of the Australian Economics Community', Working Papers in Economic History no. 183, Australian National University, Canberra, March.

Goodwin, C.D.W. (1966), Economic Enquiry in Australia, Durham, NC: Duke University Press.

Groenewegen, P. and B. McFarlane (1990), A History of Australian Economic Thought, London and New York: Routledge.

Hancock, K., B. Hughes and J. Roache (2000), 'Review of the South Australian Centre for Economic Studies', Adelaide: University of Adelaide, June.

Harcourt, G.C. (1972), Some Cambridge Controversies in the Theory of Capital, Cambridge and New York: Cambridge University Press.

Harcourt, G.C. (1977a), 'Eric Russell, 1921-77: A Memoir' Economic Record 53(144): 467-74, December.

Harcourt, G.C. (1977b), ‘Eric Russell, 1921-77: A Great Australian Political Economist', the 1977 Newcastle Lecture on Political Economy. Reprinted as Ch. 3 in Harcourt (2001).

Harcourt, G.C. (2001), Selected Essays on Economic Policy, London and New York: Palgrave.

Harcourt, G.C. and G. Mongiovi (2001), 'The Cambridge Tradition in Economics: An Interview with G.C. Harcourt' in Review of Political Economy 13(4): 503-21.

Harris, G.T. (1988), 'Research Output in Australian University Economics Departments, 1974-83', Australian Economic Papers 27: 102-110.

Harris, G.T. (1990), 'Research Output in Australian University Economics Departments: An Update for 1984-88', Australian Economic Papers 29: 249-59, December.

Horne, J., D. Greenaway and A. Pagan (2002), Review of the School of Economics, Adelaide: University of Adelaide, August. 
Jarrett, F.G., I.W. McLean, M. Meyler and C. Walsh (1987), 'The Future of the Economics Department', Submission to the 1988 External Review of the Department of Economics, Adelaide: University of Adelaide, July.

Jones, H.P. (1967), 'The History of Commercial Education in South Australia with Special Reference to Women', unpublished M.A. thesis, University of Adelaide.

Laband, D. and M.J. Piette (1994), 'The Relative Impacts of Economics Journals: 1970-1990', Journal of Economic Literature 32: 640-66.

Liewowitz, S.J. and J.P. Palmer (1984), 'Assessing the Relative Impact of Economics Journals', Journal of Economic Literature 22: 77-88, March.

Mackinnon, A. (1986), The New Women: Adelaide's Early Women Graduates, Netley: Wakefield Press.

Masons, P.M., J.W. Steagall and M.M. Fabritus (1997), 'Economics Journal Rankings by Types of Schools: Perceptions versus Citations', Quarterly Journal of Business and Economics 36: 69-79. Mayer, P.B., J. Brine, R.D. Terrell and D. Throsby (1988), Review of the Department of Economics, Adelaide: University of Adelaide, August.

McTaggart, D., C. Findlay and M. Parkin (1999), Economics (3 ${ }^{\text {rd }}$ ed.), Sydney: Addison Wesley.

Meade, J.E. and E.A. Russell (1967), 'Wage Rates, the Cost of Living and the Balance of Payments', Economic Record 33: 23-28.

Millmow, A. (2002), 'The Disintegration of Economics?' Economic Papers 21(2): 61-69, June.

Pincus, J.J. (1977), Pressure Groups and Politics in Antebellum Tariffs, New York: Columbia University Press.

Pincus, J.J. (2002), Submission to the 2002 External Review of the School of Economics, University of Adelaide, June.

Pomfret, R. (1999), 'Economics at Adelaide University: Performance in the 1990s and Future Prospects', mimeo, School of Economics, University of Adelaide, October.

Pomfret, R. and L.C. Wang (2002), 'Evaluating the Research Output of Australian Universities' Economics Departments', revision of a paper presented at the 2002 Conference of Economists, Glenelg, 1-3 October. 
Rogers, C. (2002), 'School of Economics Strategic Plan 2003-2005', Submission to the 2002 External Review of the School of Economics, University of Adelaide, August.

Russell, E.A. (1965), 'Wages Policy in Australia', Australian Economic Papers 4: 1-26.

Russell, E.A. (1978), 'Foreign Investment Policy - What Role for the Economist?' Australian Economic Papers 17: 193-206, December. Siegfried, J. (2000), 'Undergraduate Economics Degree Trends Through the 1990s', Journal of Economics Education 31(3): 296300.

Sinha, D. and J. Macri (2001), 'Rankings of Australian Economics Departments, 1988-2000', Economic Record 77(239), December.

Stretton, H. (1991), 'An Intellectual Public Servant: William Wainwright, 1880-1948', Meanjin 50(4): pp. 565-78.

Towe, J.B. and D.J. Wright (1995), 'Research Published by Australian Economics Departments', Economic Record 71: 8-17.

Turner, H.G. (1904), 'Commercial Education', the Inaugural Joseph Fisher Lecture, University of Adelaide, 14 April. Reprinted as Chapter 1 in Volume I of Anderson (2001).

University of Adelaide (2002), Research and Research Training Management Report 2002, Adelaide, July.

Viney, H.G. (1936), A Century of Commerce, 1836-1936, Adelaide: Adelaide Chamber of Commerce Inc. 


\section{Appendix 1: Biographies of Economics staff who became Professors}

Kym Anderson (1950-) B.Ag.Ec.(Hons) (UNE), M.Ec. (Adel), M.A. (Chicago), M.A. and Ph.D. (Stanford), FASSA, FAICD, CEPR has held a Personal Chair at the University of Adelaide since 1991, having been a Lecturer (1984-85) and a Senior Lecturer (1986-90) there. The Executive Director of Adelaide's Centre for International Economic Studies since he founded it in 1989, he previously was a Research Fellow in Economics at the Australian National University's Research School of Pacific and Asian Studies (1977-83). While on leave he has worked in Korea (1979, 1980-81), at the University of Stockholm (1988) and with the GATT Secretariat (now the World Trade Organization) in Geneva (1990-92) as deputy to the Director of Research. He is the first economist to have served as a Dispute Settlement Panelist at the WTO (1996-2000). His interests include international, development and agricultural economics.

Michael John Artis (1938-) B.A. (Oxon), CEPR came to Adelaide in 1964 from the Institute of Economics and Statistics in Oxford. A Lecturer in Economics at Adelaide for two years, he moved to The Flinders University of South Australia in 1966 before returning to England in 1967 to join London's National Institute for Economic and Social Research. After five years there he moved to a Chair at Swansea University College (1972-76) and then to Manchester. In 1995 he took a period of leave at the European University Institute in Florence but has stayed there and resigned from Manchester in 1999. From 1976 to 1994 he served as the editor of the Manchester School journal. His research interest is in monetary economics but he also very influential in policy circles during periods of secondment to the British Government. 
Allan Douglas Barton (1933-) B.Com. (Melb), Ph.D. (Camb), FCPA, FAICD is an Emeritus Professor of the Australian National University of which he was previously the Pro Vice-Chancellor (1992-95) and Treasurer (1984-91). From 1979 to 1983 he was the Dean of the Faculty of Economics and Commerce at the ANU, having been appointed Professor of Accounting in 1975 (a post he held until 1998). Previously, he was Professor of Accounting and Business Studies at Macquarie University (1967-74) and Reader in Commerce at the University of Adelaide (1965-66) where he had been a Senior Lecturer in Economics (1959-64). He was President of the ACT Division of the Society of CPAs (1983-84) and a Director of UniSuper Ltd (1991-99).

Maureen Brunt (1928-) A.O., B.Com. (Melb), Ph.D. (Harv), Hon. L.LD. (Monash) is a Professorial Associate at the Melbourne Business School in the University of Melbourne. She is also a Lay Member of the High Court of New Zealand. After periods as a Lecturer and Senior Lecturer at the University of Adelaide (1960-64) and a Lecturer at Harvard University (1964-66), she was appointed a Professor at Monash University in 1966 - perhaps Australia's first female Professor of Economics. She remained there until 1989. Her non-academic appointments include membership to the Australian Competition Tribunal (1975-98) and membership on the panel of arbitrators for the International Centre for Settlement of Investment Disputes (since 1995).

Raymond Peter Byron (1941-) B.Ec. (WA), M.Sc. and Ph.D. (LSE) is currently the Dean of the School of Business at Bond University in Queensland, a post which he has held since 1997. He was previously a Lecturer at the University of South Australia and at the University of Adelaide (1966) as well as a Research Officer at the National Institute for Economic and Social Research in London. He is also a Research Fellow and an Emeritus Reader at the Australian National University. His principal field of interest is econometric and 
statistical methods. He was awarded the Bowley Prize at the London School of Economics in 1969.

Bruce James Chapman (1951-) AO B.Ec.(Hons) (ANU), Ph.D. (Yale), FASSA is a Professor of Economics and the Director of the Centre for Economic Policy Research at the Research School of Social Sciences at the Australian National University. His current research interests include higher education financing, effects of immigration on the employment prospects of unemployed residents, unemployment, social security, the wage profile, youth unemployment and the business cycle. He is the architect of Australia's Higher Education Contribution Scheme which provides undergraduates with the opportunity to obtain from the Commonwealth Government an income-contingent loan to pay their tuition fees. Currently he is researching the use of the tax system for redistributive purposes such as drought relief, paid maternity leave and criminal fines.

Kevin Thomas Davis (1949-) B.Ec.(Hons) (Flinders), M.Ec. (ANU) is the Commonwealth Bank Group Chair of Finance at the University of Melbourne. Prior to moving to Melbourne in 1987, he was a Senior Lecturer (1980-86) and a Lecturer in Economics (1974-79) at the University of Adelaide. His primary research is into financial institutions and markets, financial engineering and corporate finance. He has co-authored/edited 16 books on finance, banking, monetary economics and macroeconomics and numerous journal articles and chapters in books. He is Chairperson of the Melbourne University Credit Cooperative and a course director of the Understanding Treasury Management Programme (conducted with Ernst and Young and the ANZ Bank). He has undertaken an extensive range of consulting assignments for financial institutions, business and government.

John Louis Dillon (1931-2001) B.Sc.(Agr.) (Syd), Ph.D. (Iowa State), Dr.Sc.Agr. (Kiel), D.Agr.Ec. (Syd), Hon.D.Ec. (UNE), FASSA, 
FAAEA, FAIAS was the Professor of Farm Management at the University of New England from 1965 to 1994 and then an Emeritus Professor there. He also served as UNE's Pro Vice-Chancellor from 1979 to 1981. From 1961 to 1963 he was a Senior Lecturer in Agricultural Economics at the University of Adelaide and in 1964 he was promoted to Reader in Economics. His research contributions spanned production theory, decision analysis, econometrics, operations research, systems analysis and organisation theory. As an intrepid traveller, he chaired numerous boards of trustees of international agricultural research centres in addition to the Australian Centre for International Agricultural research.

Christopher Findlay (1953-) B.Ec.(Hons) (Adel), M.Ec. and Ph.D. (ANU) FASSA has been the Professor of APEC Economies at the Australian National University's Asia Pacific School of Economics and Management since 2000, having been on the Adelaide staff since 1984 and becoming an Associate Professor in 1992. He has published extensively on Australia's economic relations with Asia, on China (which led to him co-founding Adelaide's Chinese Economies Research Centre), and on the textile, steel, food and transport industries in East Asia, as well as co-authoring with Doug McTaggart one of Australia's best-selling economic principles textbooks in the 1990s. He has been a consultant to numerous national and international agencies including UNCTAD, OECD, the World Bank and the Productivity Commission.

Noel Gaston (1954-) B.Ec.(Hons) (Adel), M.Ec. (Monash), M.A. and Ph.D. (Cornell) is a Professor of Economics at Bond University's School of Business where he is also the Deputy Dean (Research) and the Deputy Director of the Institute for Corporate Governance at Bond. He was an Associate Professor of Economics at Tulane University (1990-97) and a Lecturer at the University of New South Wales (1988-89). But between 1995 and 1998 he was a Visiting Senior Lecturer in Economics at the University of Adelaide before joining Bond University. His primary research interests involve the labour market consequences of trade and investment liberalisation, 
immigration and globalisation. He has spent several periods of leave in Tokyo, and since 1999 as a Visiting Researcher at the Research Institute for Capital Formation at the Development Bank of Japan where he is currently the Shimomura Fellow.

John McBain Grant (1923-) M.Ec. (Adel), Dip.Ec. (Camb), FASSA, FCPA has been an Emeritus Professor of the University of Tasmania since his retirement there in 1982 where he was the Professor of Applied Economics from 1960. Prior to then he was a Lecturer and then a Senior Lecturer in Economics at the University of Adelaide, from 1951 to 1959, and before that a Flight Lieutenant in the RAAF (1942-45). His research interests included business finance and trade practices, and he published several textbooks in these and related areas. He has served as a member of the Trade Practices Tribunal (1977-81), as Commissioner of the ACT's Trade Practices Commission (1982-87), and as Chairman of the Royal Commission into Prices and Restrictive Trade Practices in Tasmania in 1964.

Keith Jackson Hancock (1935-) AO, B.A. (Melb), Ph.D. (Lond), Hon.D.Litt. (Flinders), FASSA is an Honorary Fellow of the University of Adelaide and a Research Associate at the National Institute of Labour Studies at The Flinders University of South Australia. His first academic appointment was as a Lecturer in Economics at Adelaide in 1959 before he transferred to the new Flinders University in 1964 as its first Professor of Economics. He was then Pro Vice-Chancellor (1974-79), Vice-Chancellor (1980-87) and an Emeritus Professor (1988-) at Flinders. He worked on the Australian Conciliation and Arbitration Commission (1987-89) and was then appointed Deputy President of the Australian Industrial Relations Commission where he served until 1997. Since 2000 he has been the Chairman of Electricity Industry Ombudsman (SA) Ltd.

Geoffrey Colin Harcourt (1931-) AO, B.Com.(Hons) and M.Com. (Melb), Ph.D. and D.Litt. (Camb), Hon.D.Litt. (De Montfort, UK), FASSA has been an Emeritus Reader in the History of Economic 
Theory at Cambridge University since 1998 as well as an Emeritus Professor of the University of Adelaide since 1988. He began his career at Adelaide as a Lecturer in Economics in 1958 and was promoted to Professor in 1967. Just prior to that he spent a year's leave and then two years in Trinity Hall, Cambridge where he taught economics and politics before returning to Adelaide, where he remained as a Professor until 1985 (although he was on leave at Cambridge the three previous years). He was President of the Economic Society of Australia (1974-77) and was made one if its Distinguished Fellows in 1994.

Herbert Heaton (1890-1973) B.A. (Leeds), M.A. (LSE), M.Com. (Birmingham) D.Litt. (Leeds) migrated to the University of Tasmania as a Lecturer in History and Economics in 1914 and then to Adelaide in 1917 where he worked as the director of tutorial classes and lectured in history and economics. He contributed significantly to the University of Adelaide's Diploma in Commerce course and worked tirelessly to expand the discipline of economics there. However, his controversial stance on contemporary issues constrained his advancement in Adelaide, so he accepted the Chair of Economics and Political Science at Queen's University in Canada in 1925. In 1927 he transferred to the University of Minnesota where he pursued a distinguished career until his retirement in 1958. He was the President of the Economic History Association (1948-50).

Keith Sydney Isles (1902-1977) B.Com. (Tas.), B.A., M.A. and M.Sc. (Camb) was appointed Lecturer at the University of Edinburgh in 1931, after which he took up the Chair of Economics at Swansea University in Wales. From 1939 to 1945 he was the Professor of Economics at the University of Adelaide. From September 1942 he took 6-months' leave to become an economic adviser to the Commonwealth's Wartime Rationing Commission in Melbourne and was a Lieutenant-Colonel in the Directorate of Research in the Citizens Military Force in 1944. While at the Control Commission in Germany when on leave for two terms in 1945, he accepted the Chair of Economics at the University of Belfast in Northern Ireland. 
He returned to Australia in 1957 to become the Vice-Chancellor of the University of Tasmania, a post he held until his retirement in 1967.

Frank George Jarrett (1923-) B.Sc.(Agr.) (Syd), Ph.D. (Iowa State) FASSA was appointed a Lecturer in Economics at the University of Adelaide in 1953, the first person with a Ph.D. from an American Land-Grant College to be employed by the University. He gradually was promoted up the ranks and became the George Gollin Professor of Economics in 1968. From then until his retirement in 1988 as an Emeritus Professor of Economics, he served as Dean of the Faculty on four occasions. His numerous consultancies included a period with the Harvard University Development Advisory Service in Pakistan (1967-69), as well as a number of visits to Papua New Guinea. His research interests covered quantitative agricultural economics and development economics, particularly the economics of production and of agricultural research.

Professor Peter Henry Karmel (1922-) AC, CBE, B.A. (Melb), Ph.D. (Camb), Hon.L.LD. (UPNG, Qld, Melb, ANU), Hon.D.Litt. (Flinders, Murdoch, Macquarie), D.Univ (Newcastle), Ph.D. ad eundem gradun (Adel), FASSA was appointed Professor of Economics at the University of Adelaide in 1950 at the age of 28. He built up a vigorous and highly regarded department before becoming Principal-Designate of the University of Adelaide's Bedford Park campus in 1962. This became The Flinders University of South Australia in 1966 with Karmel as its first Vice-Chancellor. He was later Chairman of the Australian Universities Commission and the Commonwealth Tertiary Education Commission, and ViceChancellor of the Australian National University. He has extensive experience as chairman or member of many governmental, university-related and public-interest entities. 
John Andrew La Nauze (1911-89) B.A. (WA and Oxon) commenced at the University of Adelaide in 1935 as the Assistant Lecturer in Economics to Professor Edward Shann, fresh from a period at Oxford as a Rhodes Scholar. He succeeded Shann as the primary Lecturer upon his mentor's death early that year. He resigned at the end of 1939 to become a lecturer in a history of economics course at the University of Sydney, where he stayed until 1950 although he had a period of leave as a Research Fellow at the new Australian National University in 1947-48. He held the Chair of Economic History at the University of Melbourne from 1950, a new Chair in History there from 1955. Then he became the Professor of History in the Research School of Social Sciences at the ANU in 1966. He was renowned as the leading historian on Australia's Federation and the Australian Constitution.

Mervyn Keith Lewis (1941-) B.Ec.(Hons) and Ph.D. (Adel), FASSA was a Lecturer, a Senior Lecturer and then a Reader in Economics at the University Adelaide between 1967 and 1987. During that time he was a Visiting Scholar at the Bank of England (1979-80). He moved to the University of Nottingham in 1988 and was also a Visiting Professor of Economics at Vienna University from 1988 to 1992. In 1996 he returned to Australia to take up the National Australia Bank Chair of Banking and Finance in the School of International Business of the University of South Australia. His research interests are in money and banking, including Islamic banking, and he is the coauthor of numerous books in that area.

Robert Ken Lindner (1942-) B.Agr.Sc., B.Ec. and M.Agr.Sc. (Adel), Ph.D. (Minnesota) is a Research Professor in Agricultural Economics at the University of Western Australia, having been Executive Dean of the Faculty of Agriculture there for several years up to 2001 and before that Professor and Head of UWA's Department of Agricultural Economics. From 1971 to 1986 he was a Lecturer, Senior Lecturer and Reader in Agricultural Economics at the University of Adelaide where he also served a period as departmental Chairman. His research interests include the economics of agricultural research 
and extension in addition to resource economics. He is a past President of the Australian Agricultural and Resource Economics Society.

Harold French Lydall (1916-) B.A. (S.Africa), M.A. (Oxon) was the George Gollin Professor of Economics at the University of Adelaide (1962-67) after a year as the Professor of Commerce at the University of Western Australia. Before that he spent most of the 1950s at the Institute of Economics and Statistics and lectured at St. Peter's Hall, Oxford, before spending 1959-60 with the MIT Centre for International Studies in New Delhi. He was subsequently a Professor of Economics at the University of East Anglia (1970-78), where he was then appointed Emeritus Professor, after working with the United Nations in Geneva for four years (1967-70). His books include A Critique of Orthodox Economics (1998) as well as works on income and wealth distribution theory and the economics of Yugoslavia and India.

Douglas Francis McTaggart (1953-) B.Ec.(Hons) (ANU), Ph.D. (Chicago) had his first teaching appointment as a Lecturer in Economics at the University of Adelaide in 1987 but after a year was attracted to the new Bond University in Queensland where he quickly rose to become a Professor of Economics. With Christopher Findlay he adapted the Parkin introductory textbook for Australia and it became one of the country's best-selling economic principles textbooks in the 1990s, not least because of its early adoption of CDROM technology. From 1996 to 1998 he was the Under Treasurer and Under Secretary of the Queensland Treasury. Since 1999 then he has been the Chief Executive Officer of the Queensland Investment Corporation in Brisbane and an Adjunct Professor in the School of Business at the Queensland University of Technology.

Sir Leslie Galfreid Melville (1902-2002) KBE, CBE, B.Ec.(Hons) (Syd), Hon.L.LD., Hon.D.Sc., FIA (Lond), FIA (Aust), FASSA switched from engineering to train as an actuary and was appointed 
Public Actuary of South Australia even before completing those studies. Then in 1929, prior to his $27^{\text {th }}$ birthday, he became the first Professor of Economics at the University of Adelaide. He left his Chair in 1931 to become the first Economic Adviser to the Governor and Board of the Commonwealth (subsequently Reserve) Bank of Australia. His later distinguished career included participating in the Imperial Economic Conference in Ottawa (1932), leading the Australian delegation at the Bretton Woods Conference (1944), ViceChancellor of the Australian National University (1953-60), Chairman of the Australian Tariff Board (1960-63) and Board member of the Reserve Bank of Australia (1965-74). He stayed on at ANU's RSPAS as an honorary fellow well into the 1980s.

Sir William Mitchell (1861-1962) M.A. and D.Sc. (Edin) lectured in moral philosophy at the University of Edinburgh (1887-90) after which he lectured at University College, London and at Cambridge University. In 1894 he joined the University of Adelaide and became the Hughes Professor of English Language and Literature and also Professor of Mental and Moral Philosophy. His immediate contributions to the advancement of the University led to his election to the University Council where he sat for 52 years. Mitchell was Vice-Chancellor of the University from 1916 to 1942 whereby he became Chancellor. While his contribution was much more in other fields (they also included education, anatomy and zoology), he laid the foundation stone for the development of the discipline of economics in the University.

Trevor Mules (1945-) B.Ec.(Hons) and Ph.D. (Adel) began his academic career as a Lecturer in Economics at the University of Adelaide in 1974 and was promoted to Senior Lecturer in 1979. He helped Norm Thomson establish the joint Adelaide-Flinders Centre for South Australian Economic Studies in 1982 and served as its Director from 1985 to 1991. In 1993 he moved to the Gold Coast Campus of Griffith University where as an Associate Professor he directed a program on tourism management. Then in 2001 he took up the position of Professor of Tourism and Director of the Centre 
for Tourism Research at the University of Canberra. In that position he is also the ACT Node Coordinator for the Cooperative Research Centre on Tourism. He specialises in economic modelling of tourism events.

Duc-Tho (Tom) Nguyen (1949-) B.A. (Saigon, Wellington), Ph.D. (ANU) began his academic career as a Lecturer in Economics at the University of Adelaide (1987-89) before gaining a Professorship at Griffith University's School of Economics in Brisbane. He has served there as Head of School (1995-98) and as Dean of the Faculty (1991). During that time he has been Vice-President of the Economic Society of Australia and joint editor of the Economic Analysis and Policy journal. His research interests include macroeconomic issues in open economies, international finance, comparative economic growth, Asia-Pacific economies, simulation of dynamic economic systems, and quantitative methods.

John Reginald Piggott (1947-) B.A. (Syd), M.Sc.(Ec.) and Ph.D. (LSE), FASSA became Professor of Economics at the University of New South Wales in 1988. He had been a Lecturer in Economics at the University of Adelaide (1979-80), a Lecturer and Senior Lecturer at the Australian National University (1980-85) and a Senior Lecturer at the University of Sydney (1985-87). He was the Head of School at the University of New South Wales (1988-89) and the Presiding Member of its Faculty of Economics and Commerce (1992-98). In 1997 he was appointed Adjunct Professor of the Centre for Economic Policy Research at the ANU. His non-academic appointments include membership of the steering committee for the Retirement Income Modelling Task Force (1994-97). His research interests are the economics of pensions and retirement, computable general equilibrium and public finance.

Jonathan James Pincus (1939-) B.Ec. (Qld), M.A. and Ph.D. (Stanford), FASSA has been the George Collin Professor of Economics at the University of Adelaide since 1991, the Head of 
School (1991-96) and the Convenor of the Academic Board (19982001). From 1985 he was Professor and Head of the Economic History Discipline at Flinders University and a Fellow in Economic History at the Australian National University's Research School of Social Sciences (1974-85). He has been involved with several journals, including terms as joint editor of Australian Economic History Review and Australian Economic Papers. In 1973 he received the Columbia Nevins Prize in American Economic History for his seminal Ph.D. thesis (subsequently published by Columbia University Press in 1977). In late 2002 he moved to Australia's Productivity Commission as Principal Advisor Research.

Richard Pomfret (1948-) B.A. (Reading), M.A. (East Anglia), Ph.D. (Simon Fraser) FASSA has been Professor of Economics at the University of Adelaide since 1992. He was the Dean of the School of Economics from 1997 to 1999. Prior appointments were at the Kiel Institute (1974-76), Concordia University in Montreal (1976-79) and Johns Hopkins University's campuses in Bologna, Washington and Nanjing (1979-91) where he rose to be Professor in 1988. He has been a consultant with such agencies as the World Bank, UNDP, EU, Arab Monetary Fund, ADB, ASEAN and UN-ESCAP. In 1990 he was Visiting Professor at the American University in Paris and in the following year he was Visiting Professor at Simon Fraser University. He has published profusely in his principal interests of economic development, trade and economic history.

Alan Anthony Leslie Powell (1937-) AM, B.Sc.(Agr.) and Ph.D. (Syd), FASSA spent a year as a Postdoctoral Fellow in Political Economy at the University of Chicago (1964) before becoming a Lecturer in Economics at the University of Adelaide (1962-64). He then moved to the new Monash University as a Senior Lecturer in Econometrics where he rose to Reader (1966) and Professor (1968). He transferred to the Richie Research Chair at the University of Melbourne in 1979 but returned to Monash in 1991. From 1975 to 1992 he was the Director of the Commonwealth Governmentfunded IMPACT project (now absorbed in the Centre of Policy 
Studies at Monash). He was a key mentor in developing the ORANI and MONASH models of the Australian economy and the GTAP model of the global economy as well as a supporter of modelling other national economies including Indonesia's.

Eric Stapleton Richards (1940-) B.A. and Ph.D. (Nottingham), FASSA, FAAH began his academic career as a Tutor and then Lecturer in Economics at the University of Adelaide (1963-67) before moving to History at the University of Stirling in Scotland (1967-71). He returned to South Australia to become a Lecturer in Economic History (1971), Senior Lecturer in Economic History (1972-73) and Reader in Economic History (1974) before becoming the Professor of History (1975-) at The Flinders University of South Australia. However, he has had periods of leave as a Visiting Professor at numerous places such as the University of London, the European University Institute, and the ANU. He has published numerous books, including on Scottish Highland history and on the early and 20th century history of Australian immigration, as well as the Flinders History of South Australia.

Sue Richardson (1946-) B.Com.(Hons) (Melb), Ph.D. (La Trobe), FASSA joined the University of Adelaide's Department of Economics in 1974 as a Lecturer and rose to Associate Professor by 1992. In 2001 she took leave to become the Professor of Labour Economics and the Director of the National Institute of Labour Studies at The Flinders University of South Australia. She has been the Convener of the Academic Board and a member of the University's Council and of its Finance Committee. Between 1995 and 1997 she was an Associate Commissioner (on a half-time basis) with the Industry Commission (now the Productivity Commission). She is a member of the Executive of the Academy of the Social Sciences in Australia and chairs its Research Committee. At various times she has been a visiting scholar at the Australian National University, Cambridge and Columbia University. 
David Keith Round (1945-) B.Ec.(Hons) (Adel) was employed in the Department of Economics at the University of Adelaide for 31 years: Lecturer (1971-75), Senior Lecturer (1976-80) and Associate Professor (1981-2001). He has since become Professor of Economics at the University of South Australia. His field is applied microeconomics, especially industry profitability, strategic behaviour, competition policy, price-fixing, mergers and economics education. His research has been particularly concerned with the Trade Practices Act. Besides holding other academic positions, he has been a consultant to the National Companies and Securities Commission, an Associate Commissioner of the Trade Practices Commission and its successor, the Australian Competition and Consumer Commission, and was appointed a member of the Australian Competition Tribunal.

Eric Alfred Russell (1921-1977) B.A.(Hons) and B.Com. (Melb), B.A. and M.A. (Camb), FASSA began his academic career as a Lecturer at the New England University College (1947-50) and the University of Sydney (1951) before he joined the University of Adelaide in 1952 as a Senior Lecturer in Economics. He rose to Professor in 1964 and chaired the Department of Economics from 1967 to 1975 before taking a year's leave at the London School of Economics. He appeared for the ACTU before the Commonwealth Conciliation and Arbitration Commission (1959), went on a UNESCO mission to Northern Rhodesia (1963), presided over the Economics section of the ANZAAS Conference (1972) and served on the Australian Advisory Committee on Research and Development in Education (1970-75). He is most highly respected as a teacher and policy advisor rather than being a prolific author.

Edward Owen Giblin Shann (1884-1935) B.A. (Melb) started his career as a temporary lecturer at the University of Melbourne in 1905 and 1907-08, and as Acting Professor of Philosophy at the University of Adelaide in 1906. In 1908 he left for the London School of Economics to study for a D.Sc., which was not completed due to illness. In 1911 and 1912 he lectured at the University of Queensland 
and then was appointed the Foundation Professor of History and Economics at the University of Western Australia (where he also served as Vice-Chancellor 1921-23). In 1933 he accepted the Chair of Economics at Adelaide that had been vacated by Professor Melville. With John La Nauze as his assistant, he arrived for the start of 1935. Tragically, he was found dead on the last day of the first term. His death remains shrouded in mystery.

John Hedley Brian Tew (1917-) OBE, B.Sc.(Ec.) (Lond), Ph.D. (Camb) was the Professor of Economics at the University of Adelaide from October 1946 to December 1949 when he resigned on a visit to the United Kingdom to become the Professor of Economics at the University of Nottingham (1950-67). From 1967 to 1982 he was the Midland Bank Professor of Money and Banking at Nottingham. He was External Professor at Loughborough University of Technology from 1982 to 1999. He served on several industrial boards, was a member of the British Department of Trade and Industry's Committee of Enquiry on Small Firms (1969-71) and from 1982 he was Specialist Advisor to the House of Commons Treasury and Civil Service Committee. He has published widely on banking, finance, monetary theory and international monetary arrangements.

Rod Tyers (1948-) B.Eng. and M.Eng.Sci. (Melb), M.S. and Ph.D. (Harvard) was a Research Fellow at the East-West Centre in Hawaii (1979-81) and then a Research Fellow in Economics at the Australian National University's Research School of Pacific and Asian Studies (1982-87). From 1987 to 1990 he was a Senior Lecturer in Economics at the University of Adelaide. He returned to the ANU in 1990 as a Senior Lecturer in its teaching Department in the Faculty of Economics and Commerce. He was promoted to Reader in 1993, after a year as a Visiting Fellow at Clare Hall in Cambridge, and then to Professor at the ANU in 2001. His love of teaching has caused him to cover a wide field of subjects from first year to graduate level. His research interests include applications of quantitative economic models to trade-related policy issues. 
Clifford Walsh (1946-) B.Sc.(Ec.)(Hons) and M.Sc.(Ec.) (London) came to Australia initially as a Lecturer at the Australian National University (1971-77). He then took a Senior Lectureship in Economics at Monash (1977-80) before accepting the position of Professor of Economics at the University of Adelaide where he was also Head of the Department. In 1981 he took 2 years' leave to be the Senior Economic Adviser to Prime Minister Malcolm Fraser. In 1988 he became the Director of the Federalism Research Centre at the ANU before returning to Adelaide in 1992 as Professor of Economic Studies and the Executive Director of the South Australian Centre for Economic Studies. His post was converted to Emeritus Professor in 2001. He has been a consultant to the Housing Industry Association since 1983 and to numerous governments around the world on federal fiscal issues.

Donald Henry Whitehead (1931-1980) B.A. (Oxon) was a Lecturer specializing initially in economic development at the University of Adelaide from 1958 to 1963 before being promoted to Senior Lecturer in economics more generally in 1964. In 1965 he moved to a Readership at the University of New England before becoming one of the two foundation Professors of Economics at La Trobe University in Melbourne in 1967, where he stayed until his death. As an analyst of stagflation, he was one of the few economists willing to give evidence on behalf of employers in arbitration cases, including against the ACTU President at the time, Bob Hawke (who was being advised by Adelaide's Eric Russell!). The Donald Whitehead Building on the Bundoora campus of La Trobe University, which houses the School of Business, was named in his honour shortly after his death.

Sir Bruce Rodda Williams (1919-) KBE, B.A.(Hons) (Melb), M.A. (Adel), M.A.(Ec.) (Manchester), Hon.D.Litt. (Sydney, Keele), Hon.L.LD. (Melb, Manchester), Hon.D.Ec. (Qld), Hon.D.Sc. (Aston), FASSA was a Lecturer in Economics at the University of Adelaide (1940-46). He was Acting Head of Economics at Adelaide when Professor Isles was on leave during World War II. He moved to a 
Senior Lectureship at Queens University in Belfast, Northern Ireland (1946-50) before being appointed Professor of Economics at Keele University (1950-59) and then at Manchester (1959-67). He came back to Australia as Vice-Chancellor of the University of Sydney (1967-81) and after that remained active as a member of the Senate, including as Chairman of the Finance Committee (1994-98). Among his extra-curricula activities has been his role as Chairman of the Sydney International Piano Competition. 


\section{Appendix 2: Charts}

Page

Chart 1: $\quad$ Economics Lecturers A-E by level, 1901-2002 68

Chart 2: $\quad$ Economics Lecturers B-E by level, 1946-2002 69

Chart 3: $\quad$ Economics Lecturers B-E by gender, 1946-2002 70

Chart 4: $\quad$ Commerce Lecturers A-E by level, 1954-2002 71

Chart 5: Advanced Certificate, Diploma and Bachelor 72 graduates, 1904-1957

Chart 6: B.Ec. and B.Fin. graduates, 1945-2002 73

Chart 7: $\quad$ B.Ec., B.Com. and B.Fin. graduates, 1990-2002 74

$\begin{array}{lll}\text { Chart 8: } & \text { B.Ec. admissions by gender, 1969-2002 }\end{array}$

Chart 9: Honours, Masters and Ph.D. graduates, 1945-2002 76

Chart 10: Growth in double degree enrolments, 1992-2001 77

Chart 11: Double degree enrolments with B.Ec., 1992-2001 78

Chart 12: $\quad$ Double degree enrolments with B.Fin., 1997-2001 79

Chart 13: Double degree enrolments with B.Com., 1992-2001 80

Chart 14: Double degree enrolments with LL.B., 1992-2001

Chart 15: Double degree enrolments with B.A., 1992-2001 81

Chart 16: Double degree enrolments with B.Eng., 1992-2001 82 


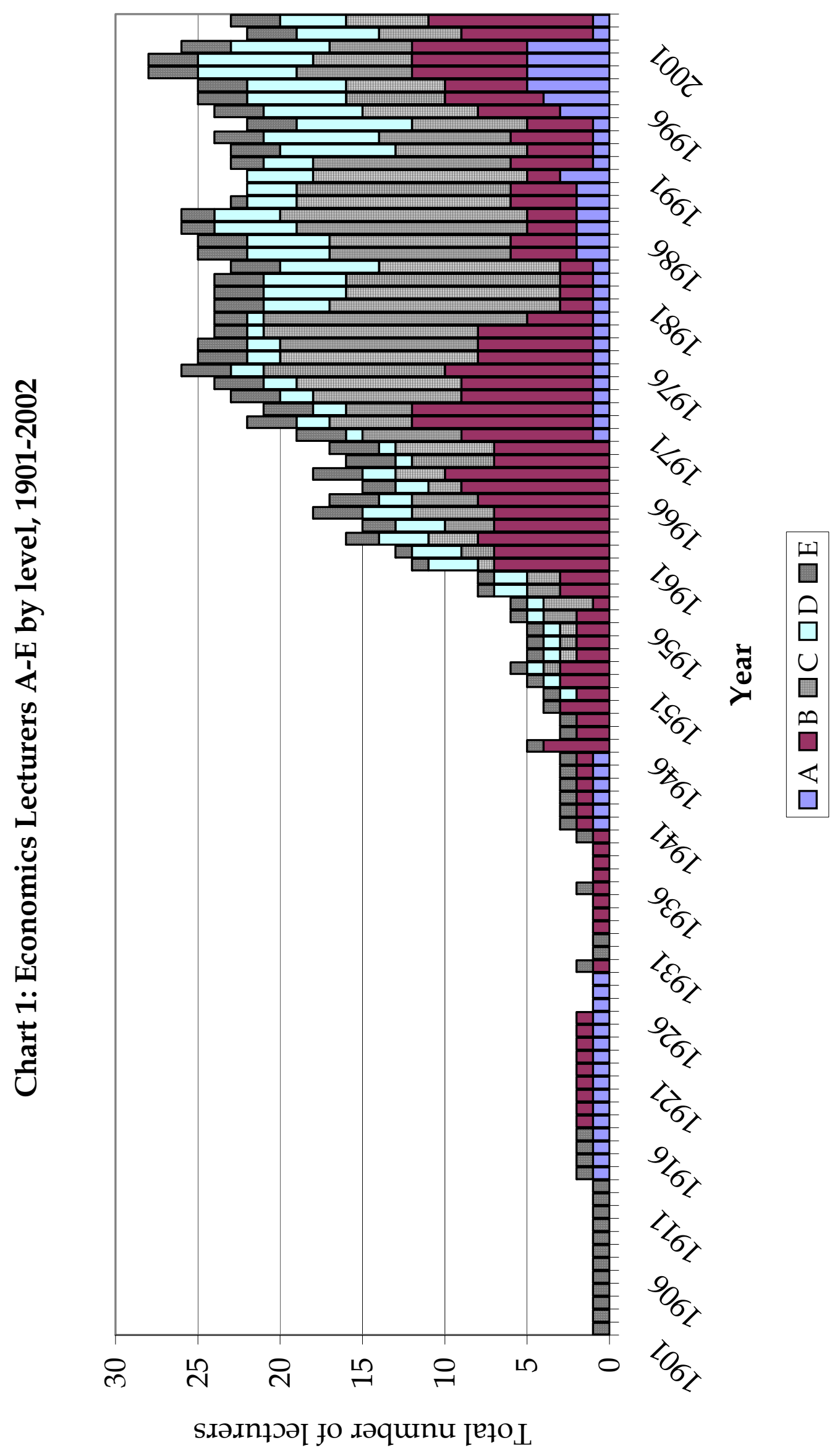




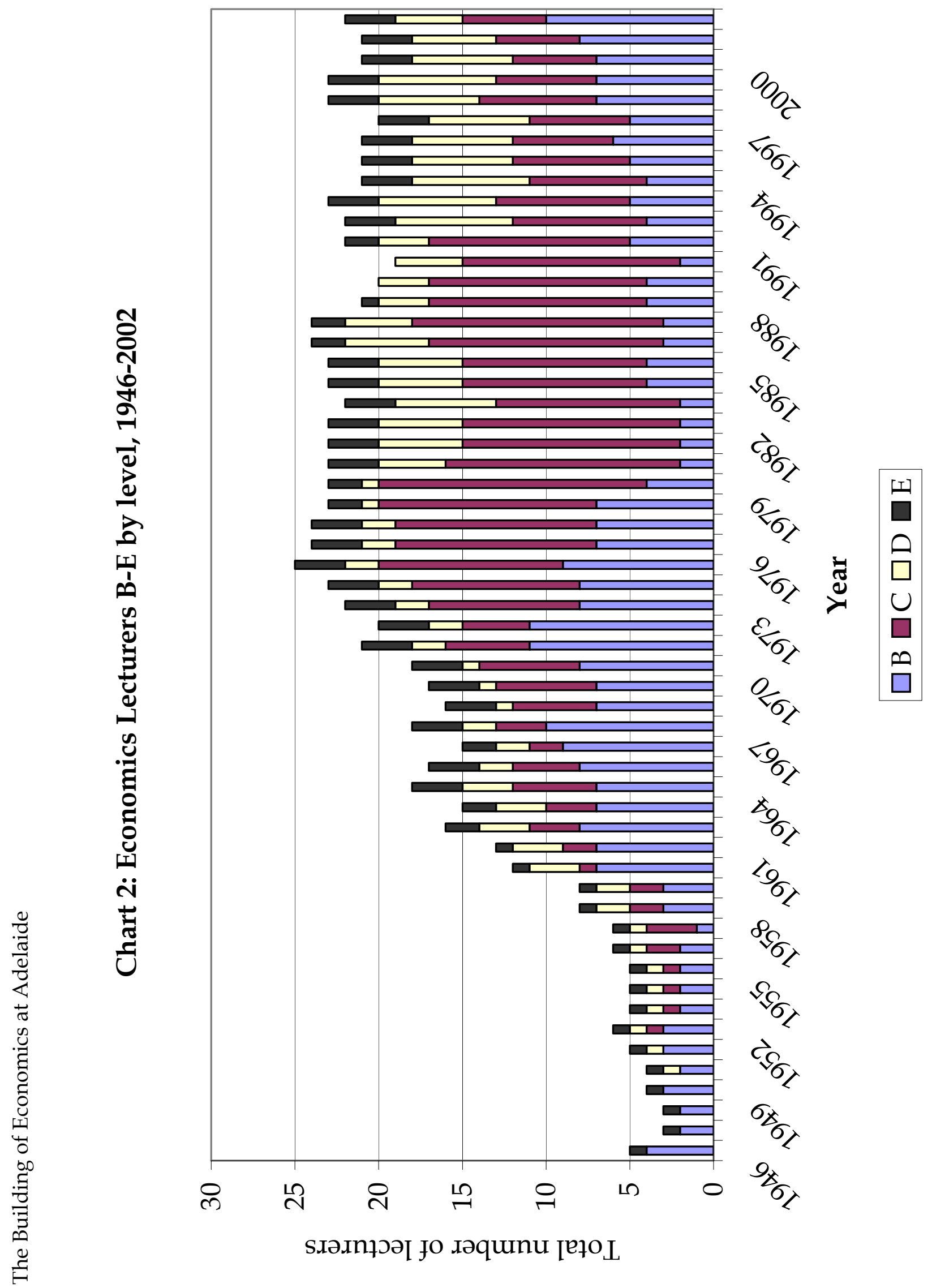




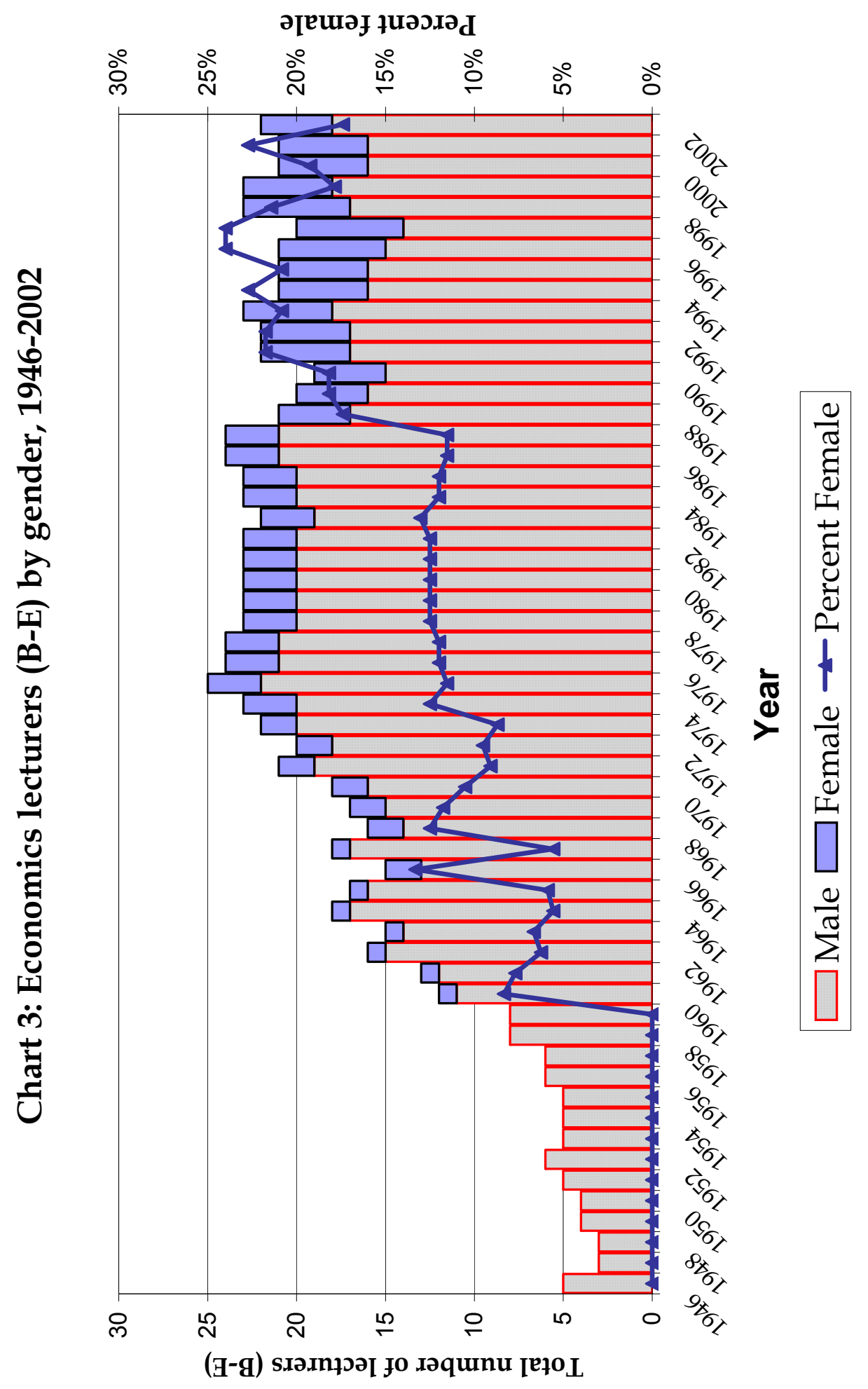




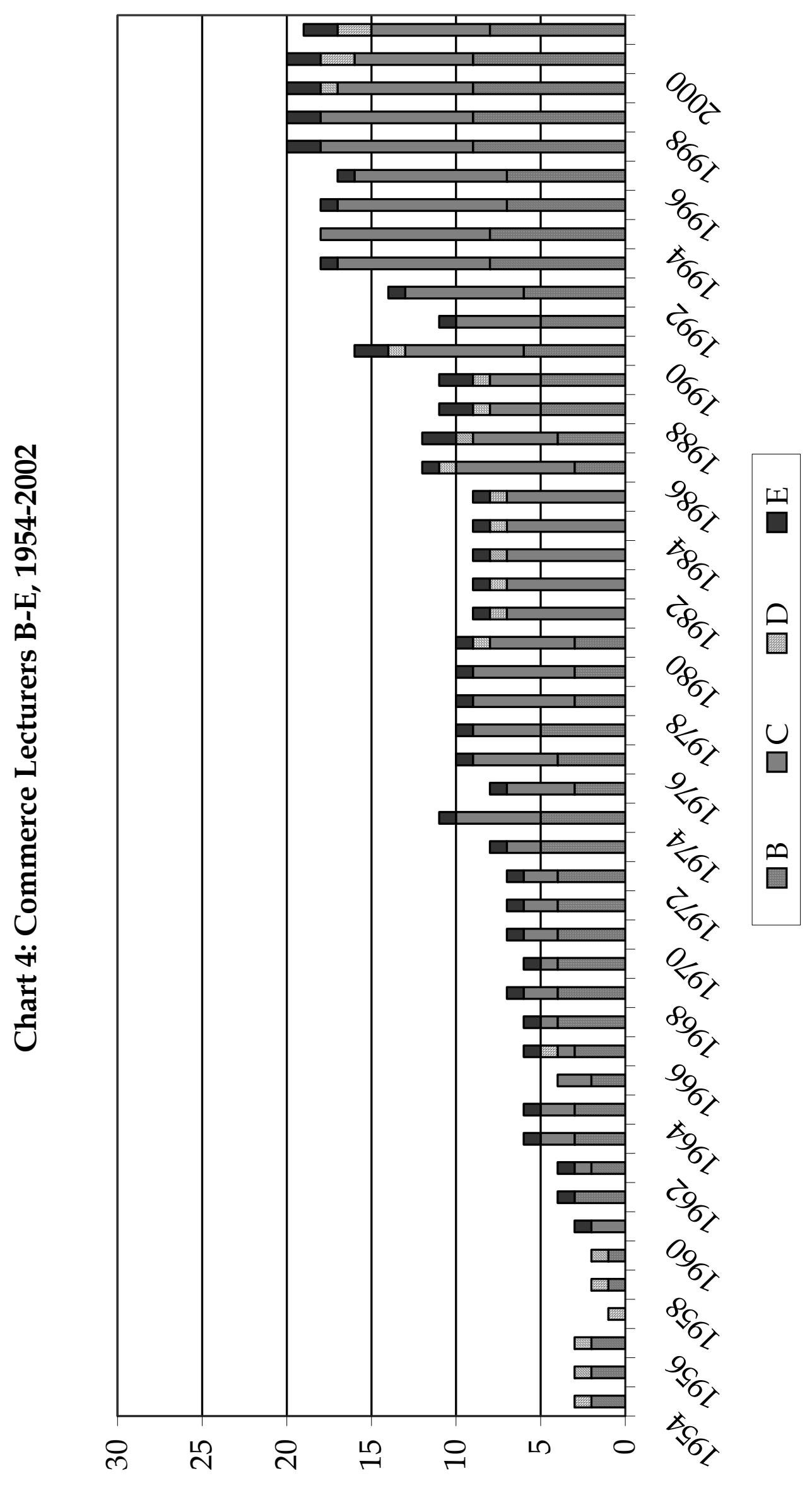




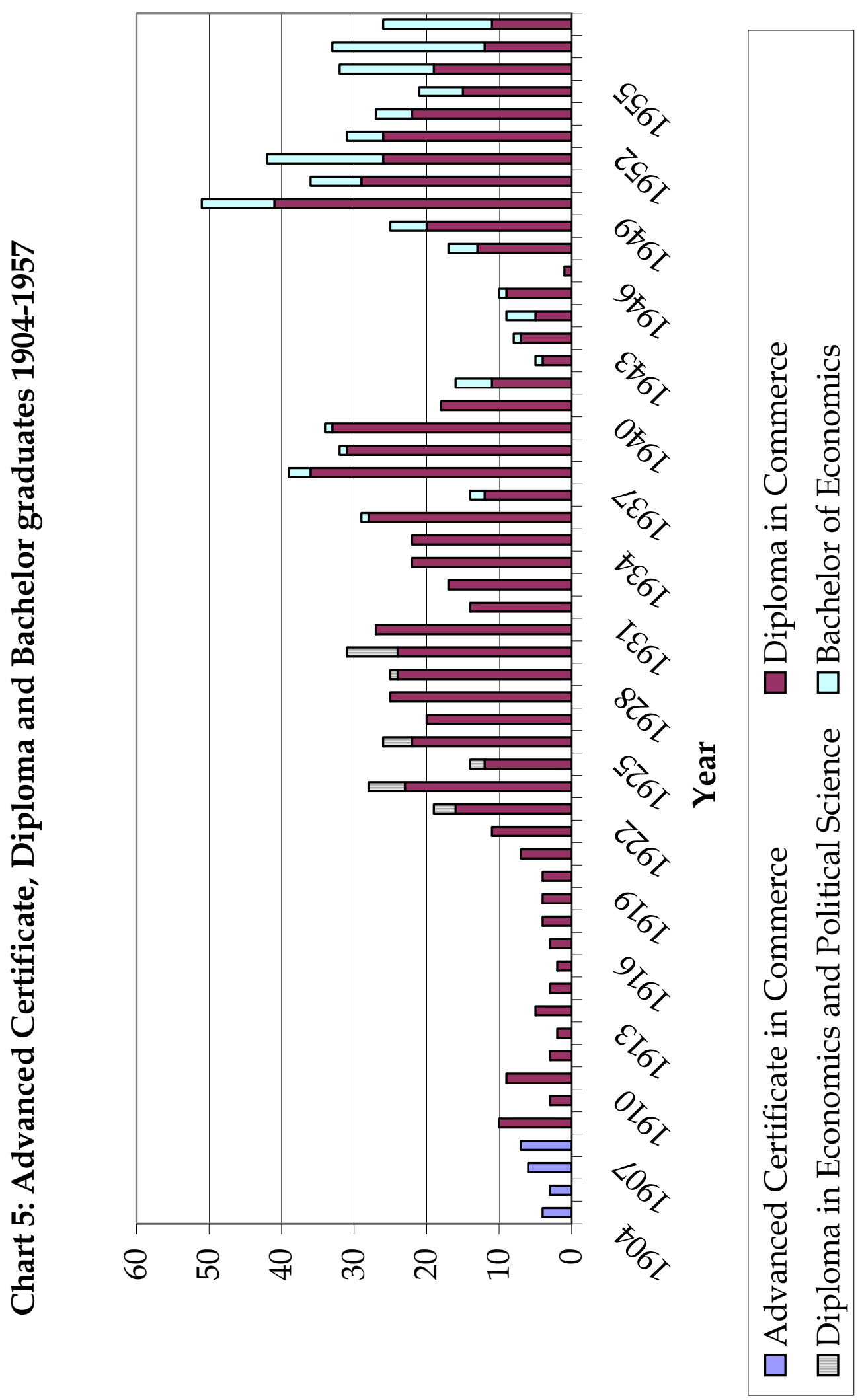

sәңеnредя јо ләqunu [eło L 


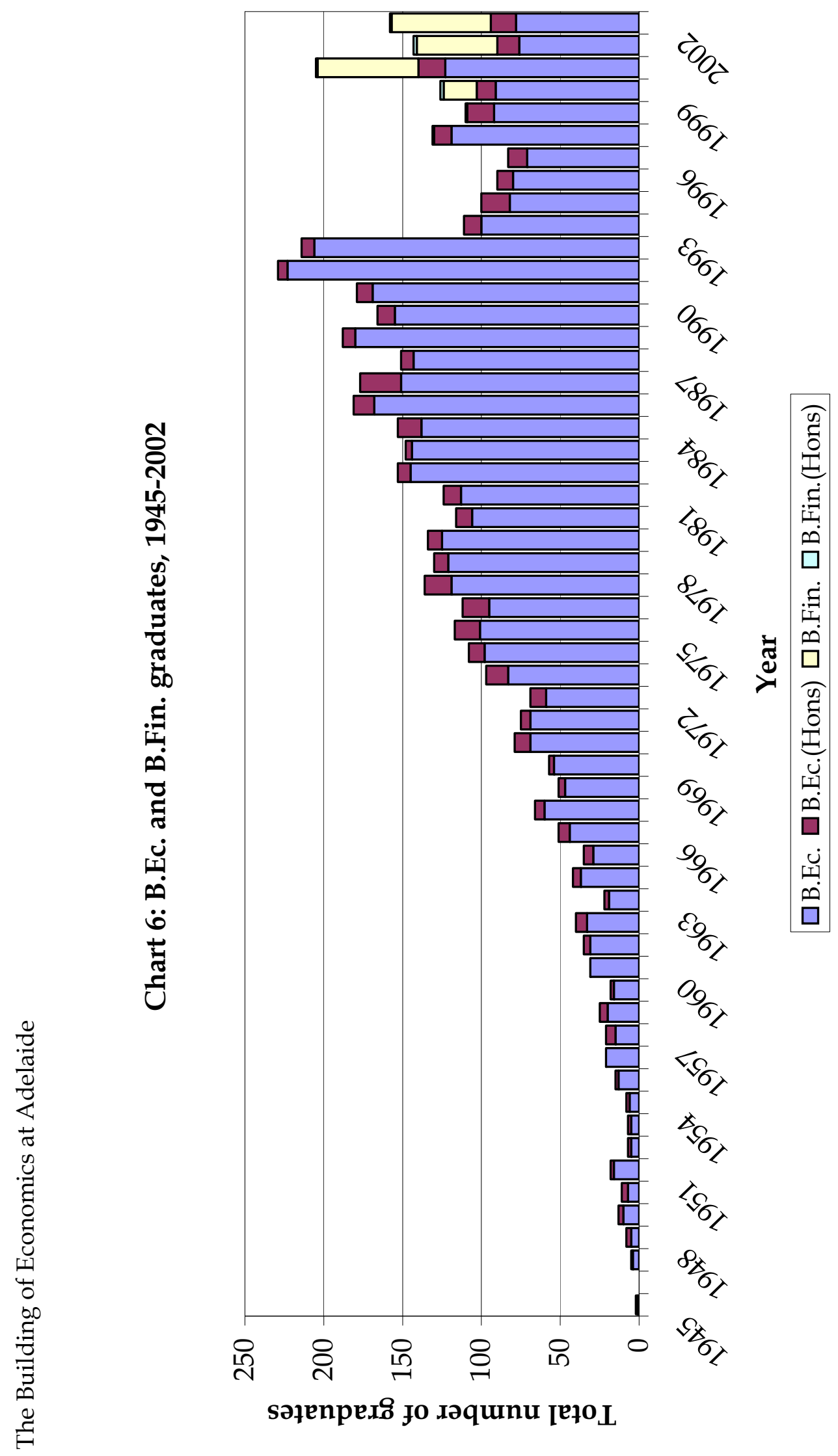




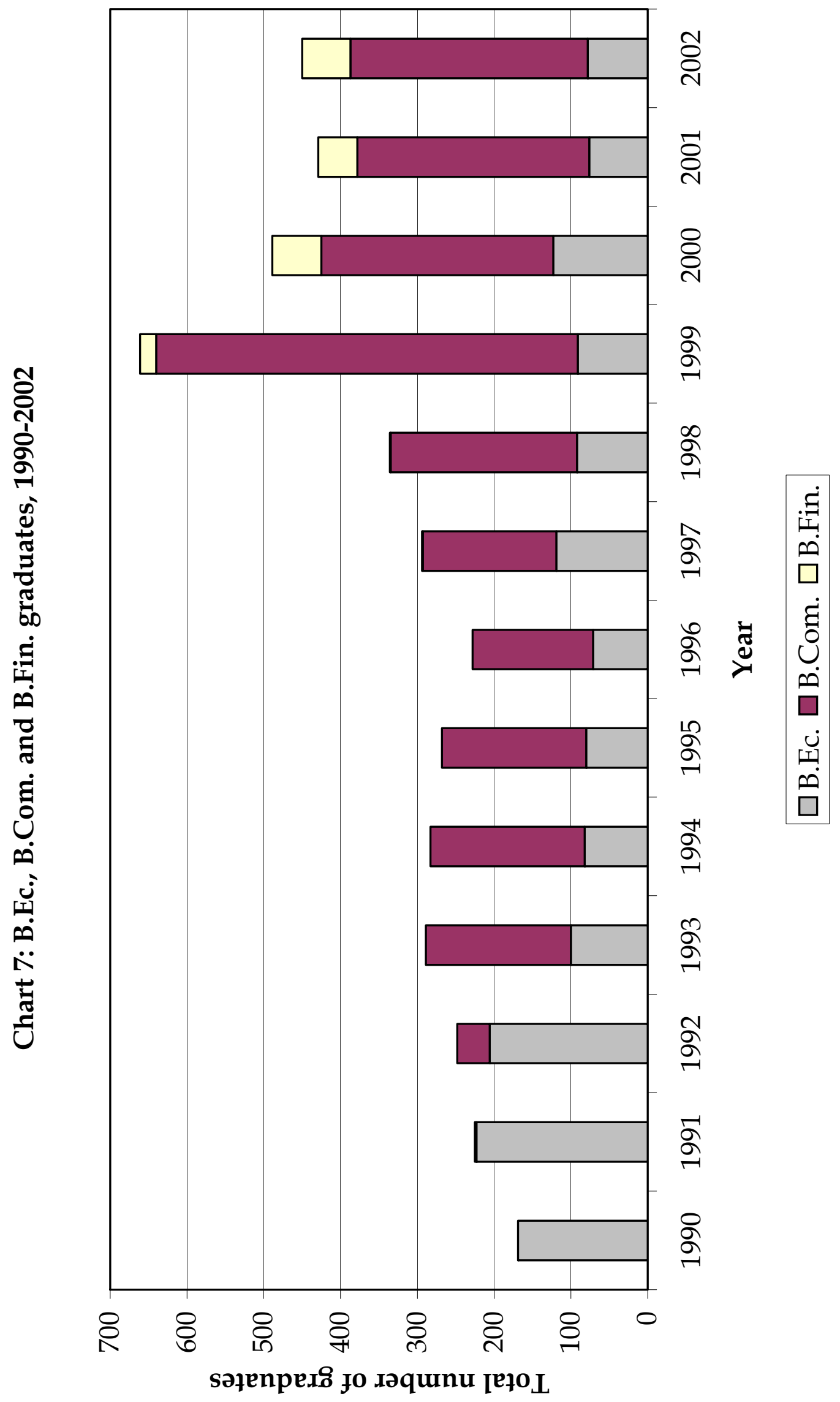




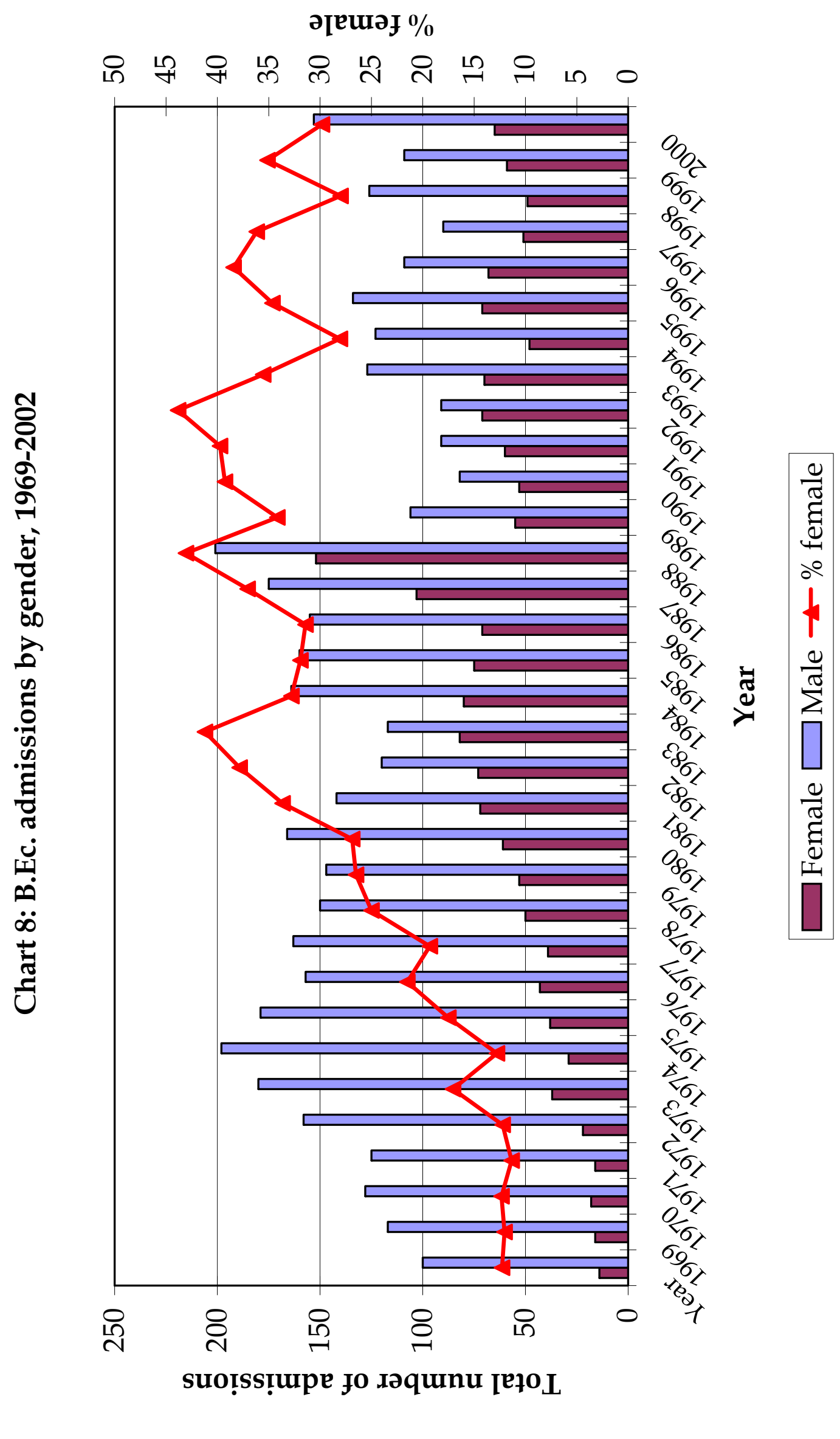


Chart 9: Honours, Masters and Ph.D. graduates, 1945-2002

Ph.D. graduates, 1971-2002

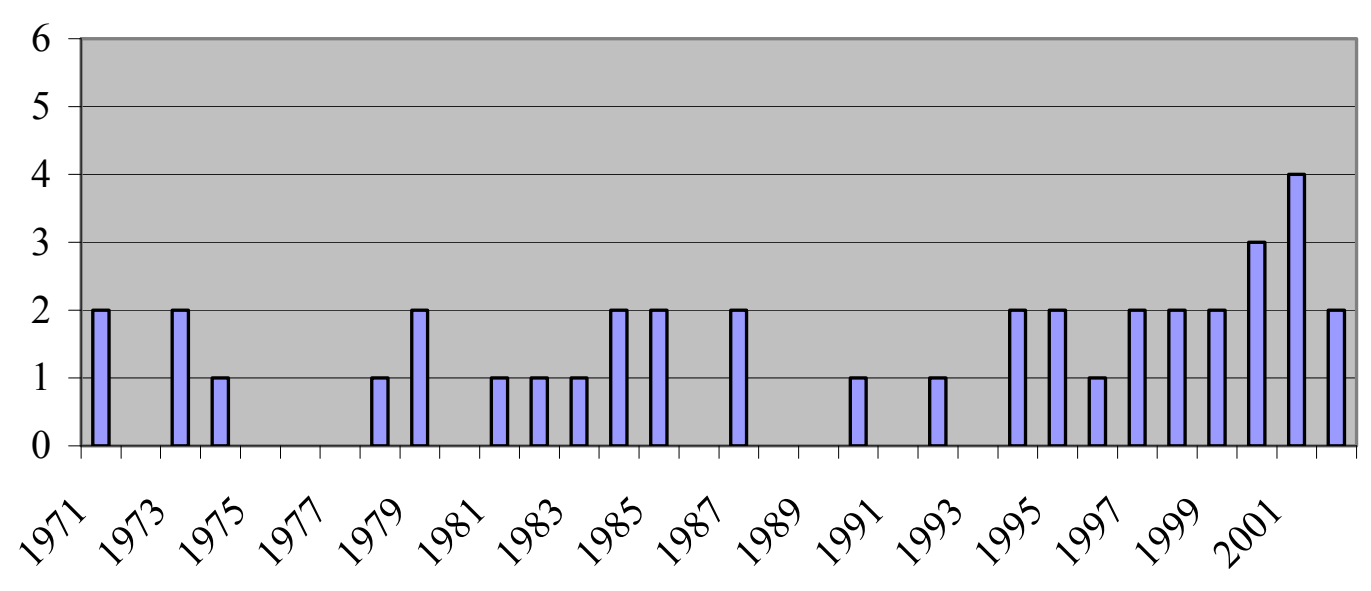

Masters (Research) graduates, 1950-2002

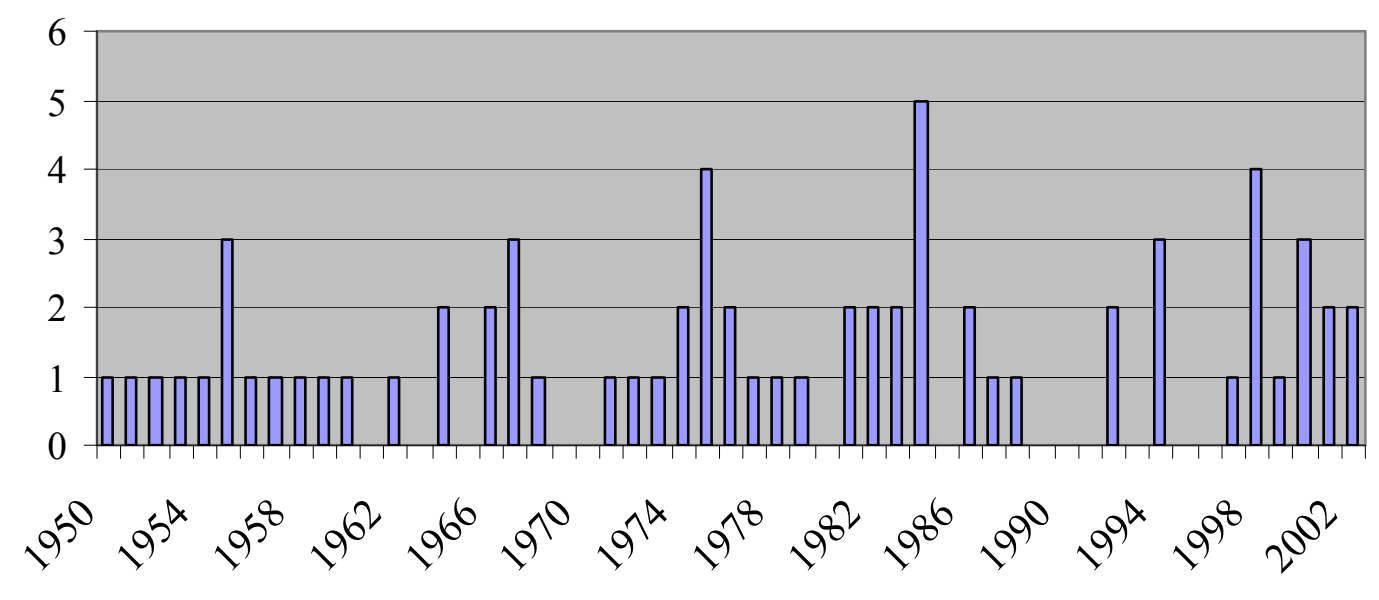

Honours Graduates, 1945-2002

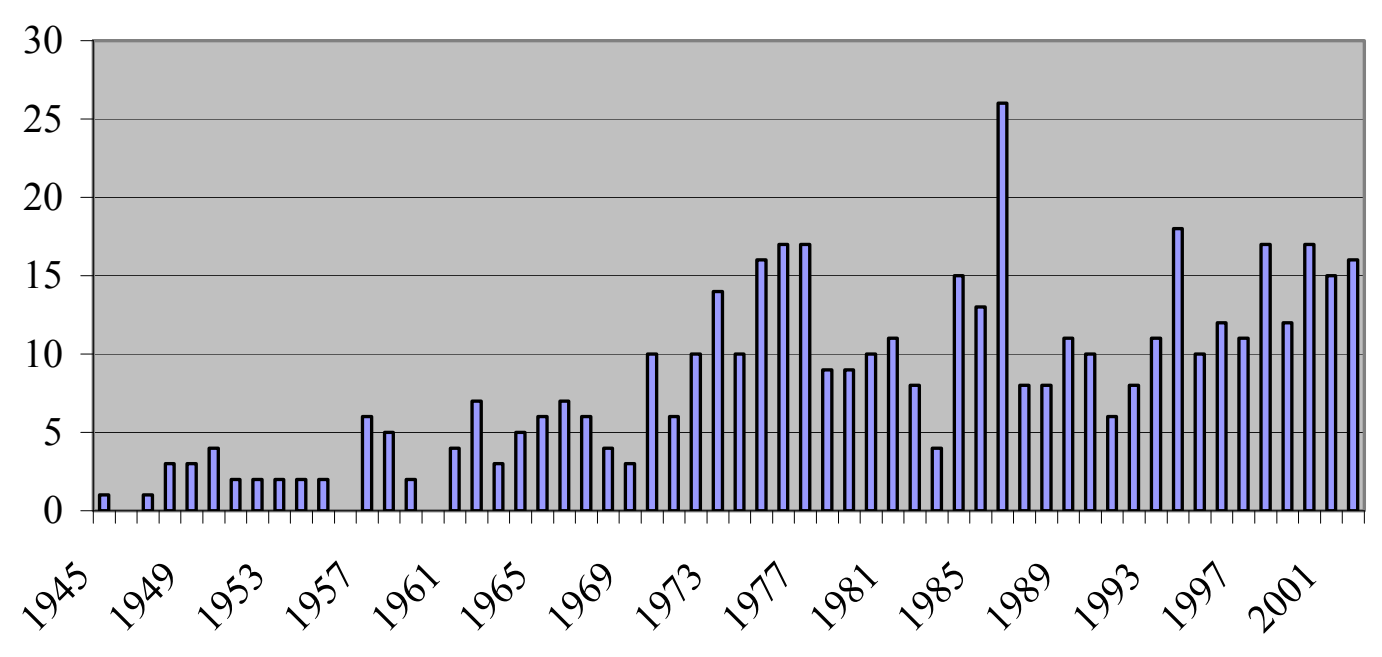




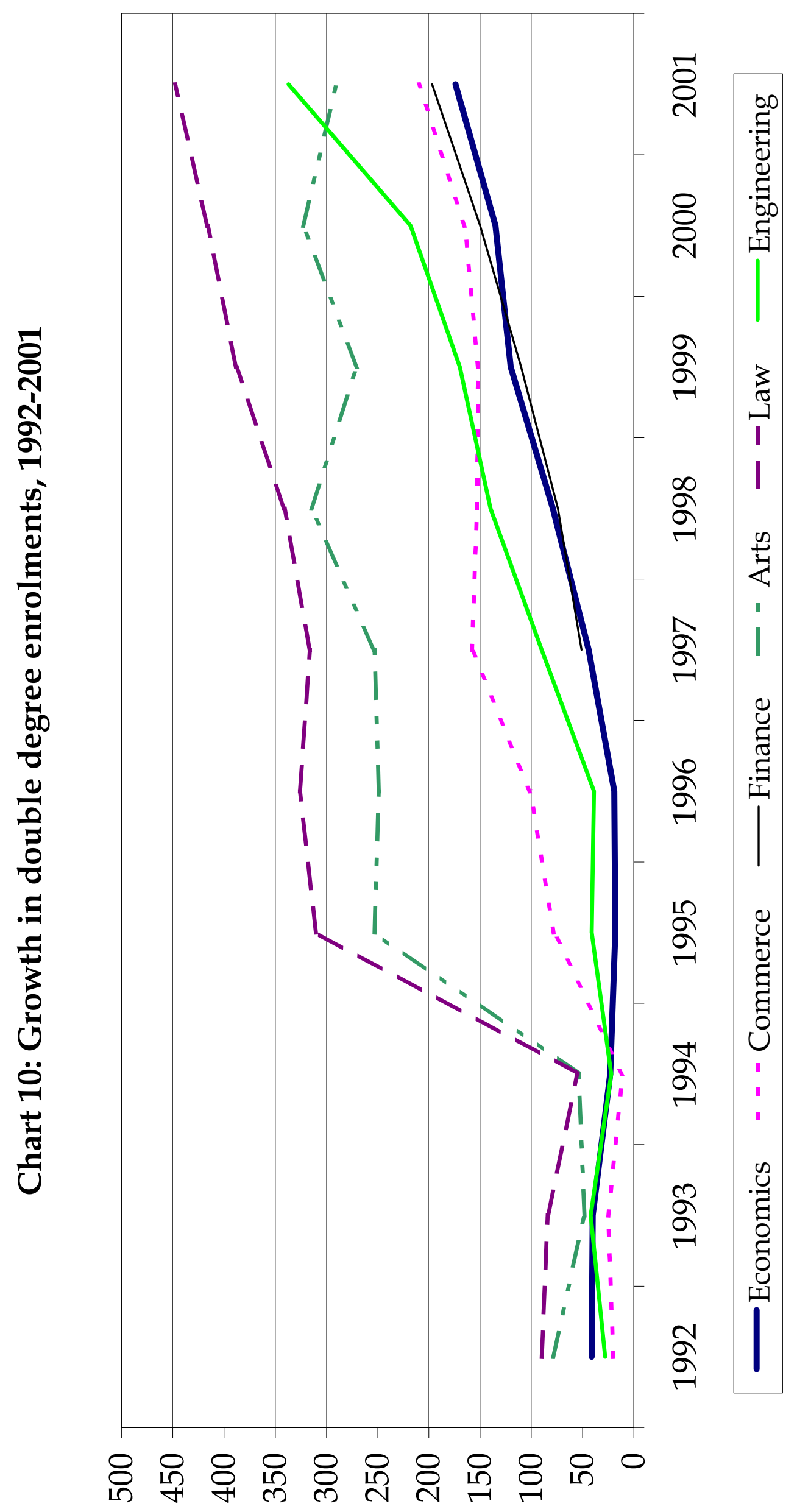




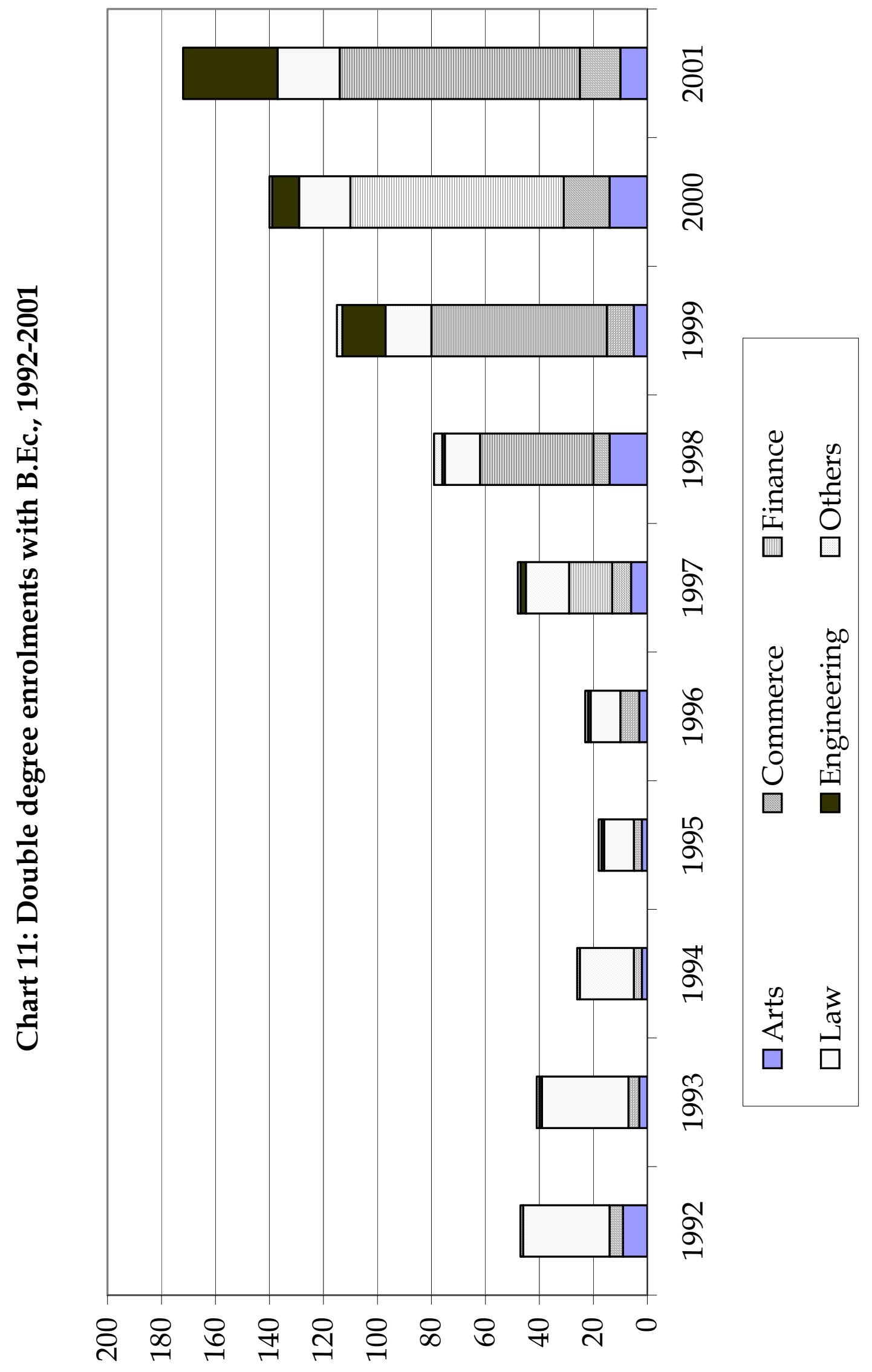




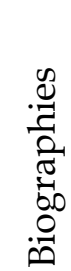

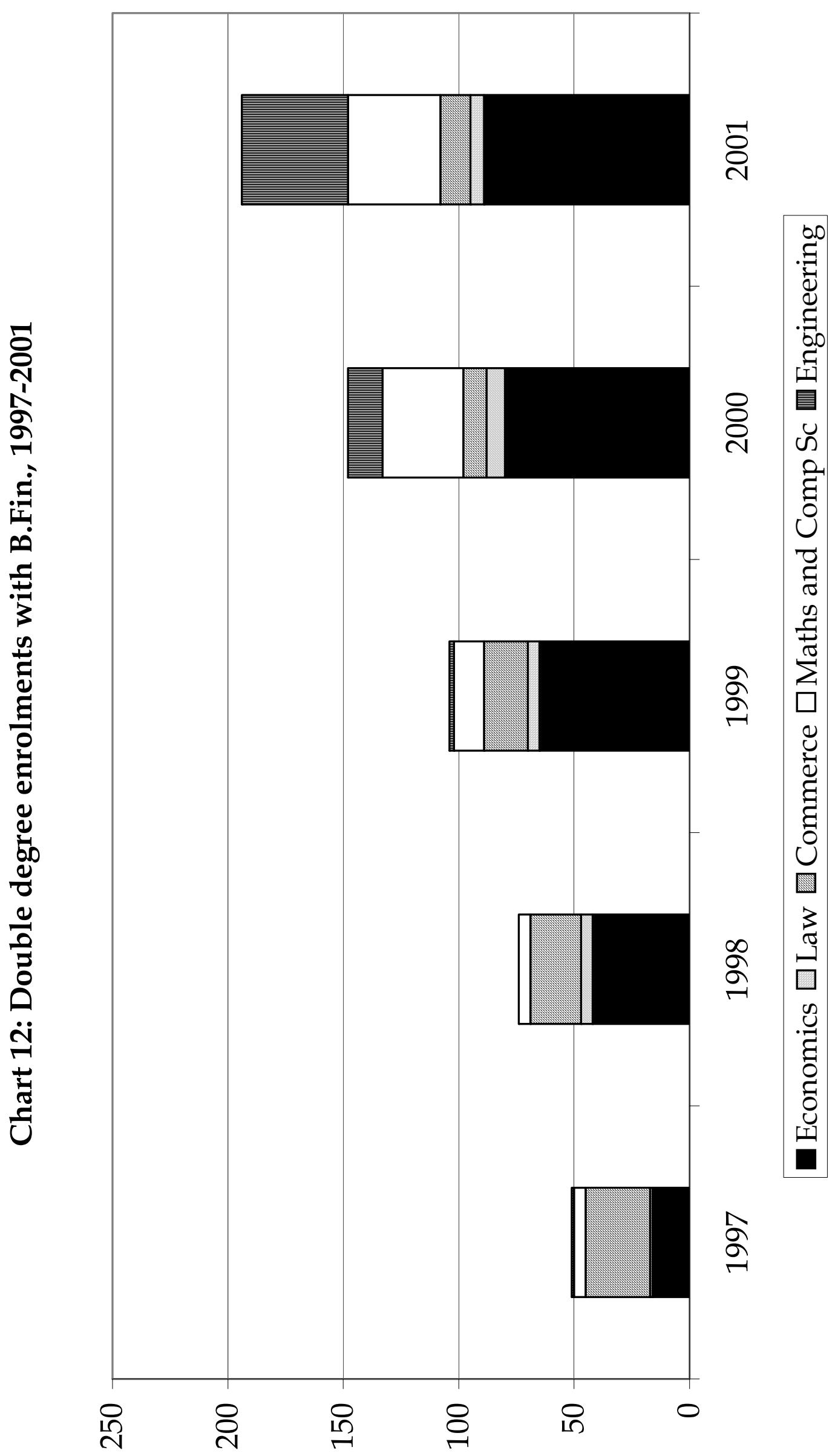




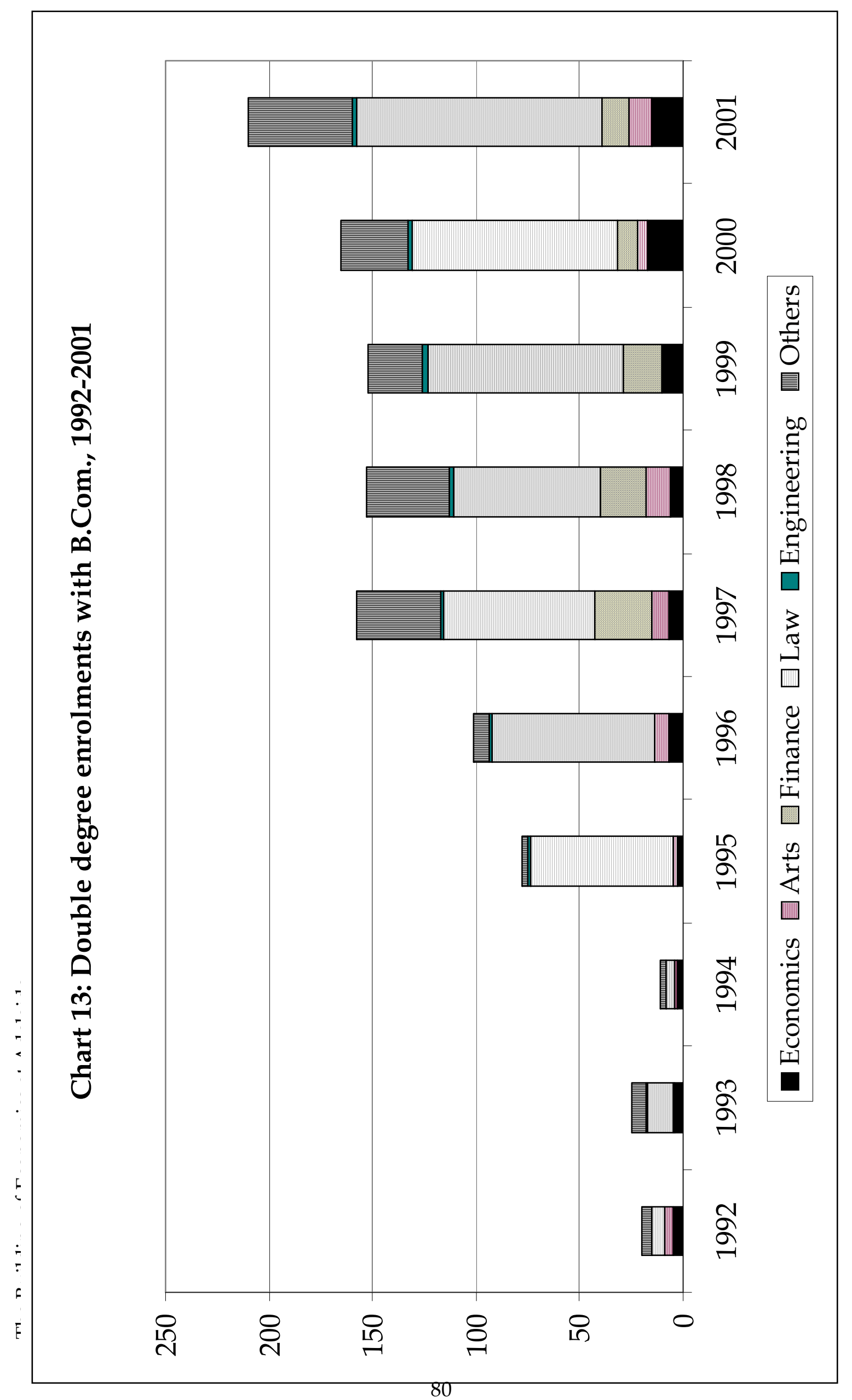




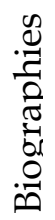

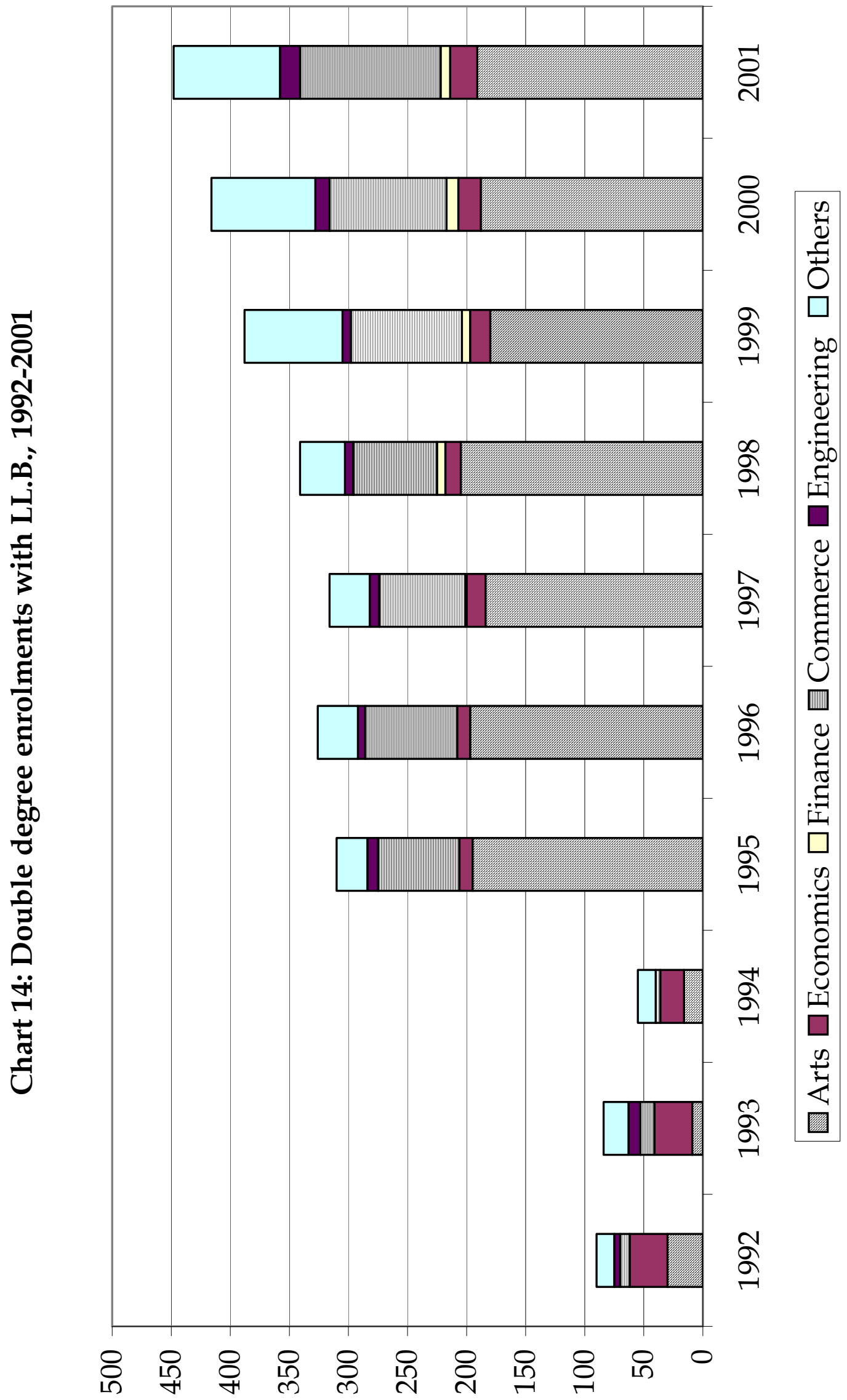




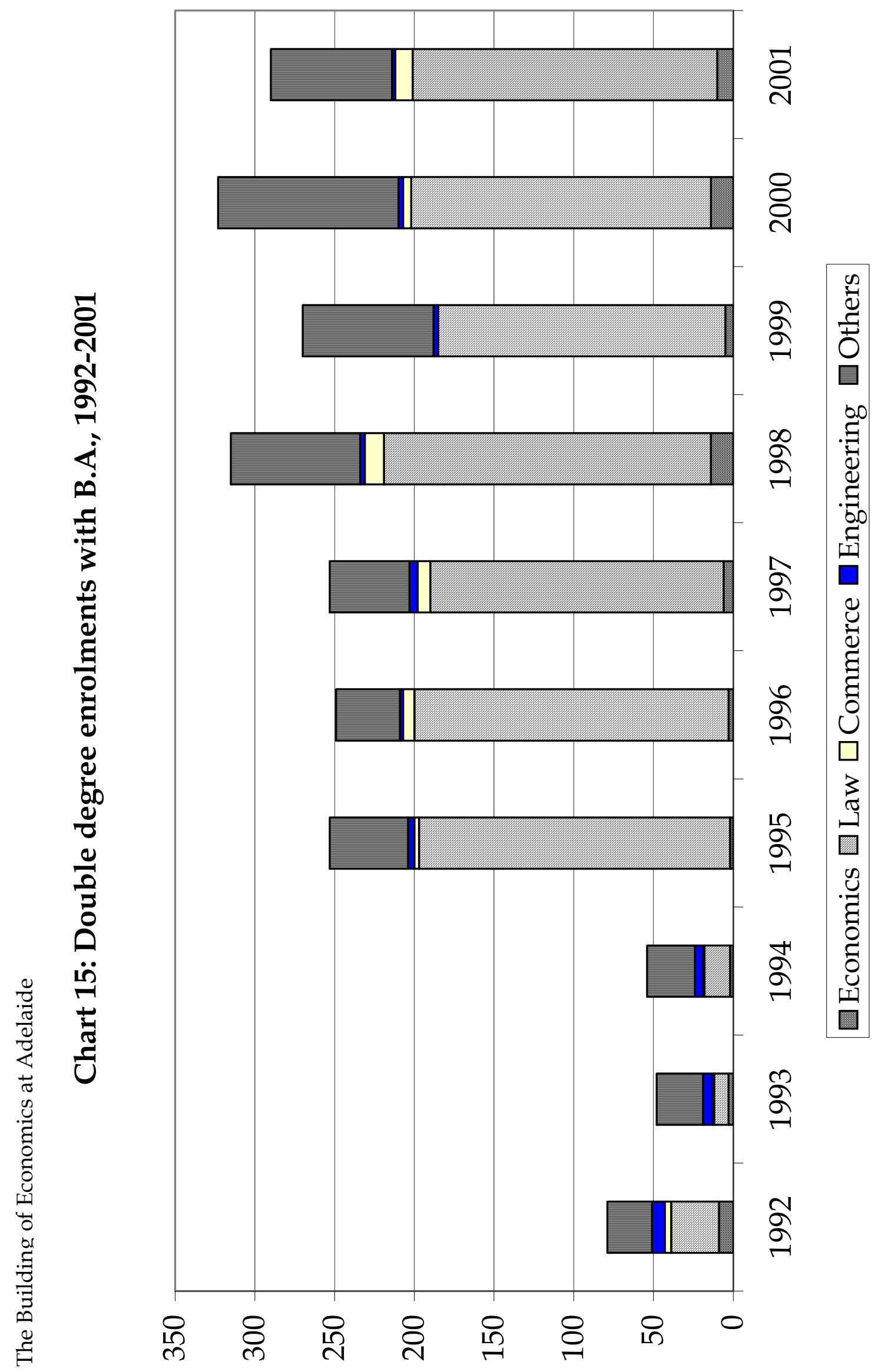




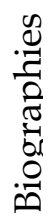

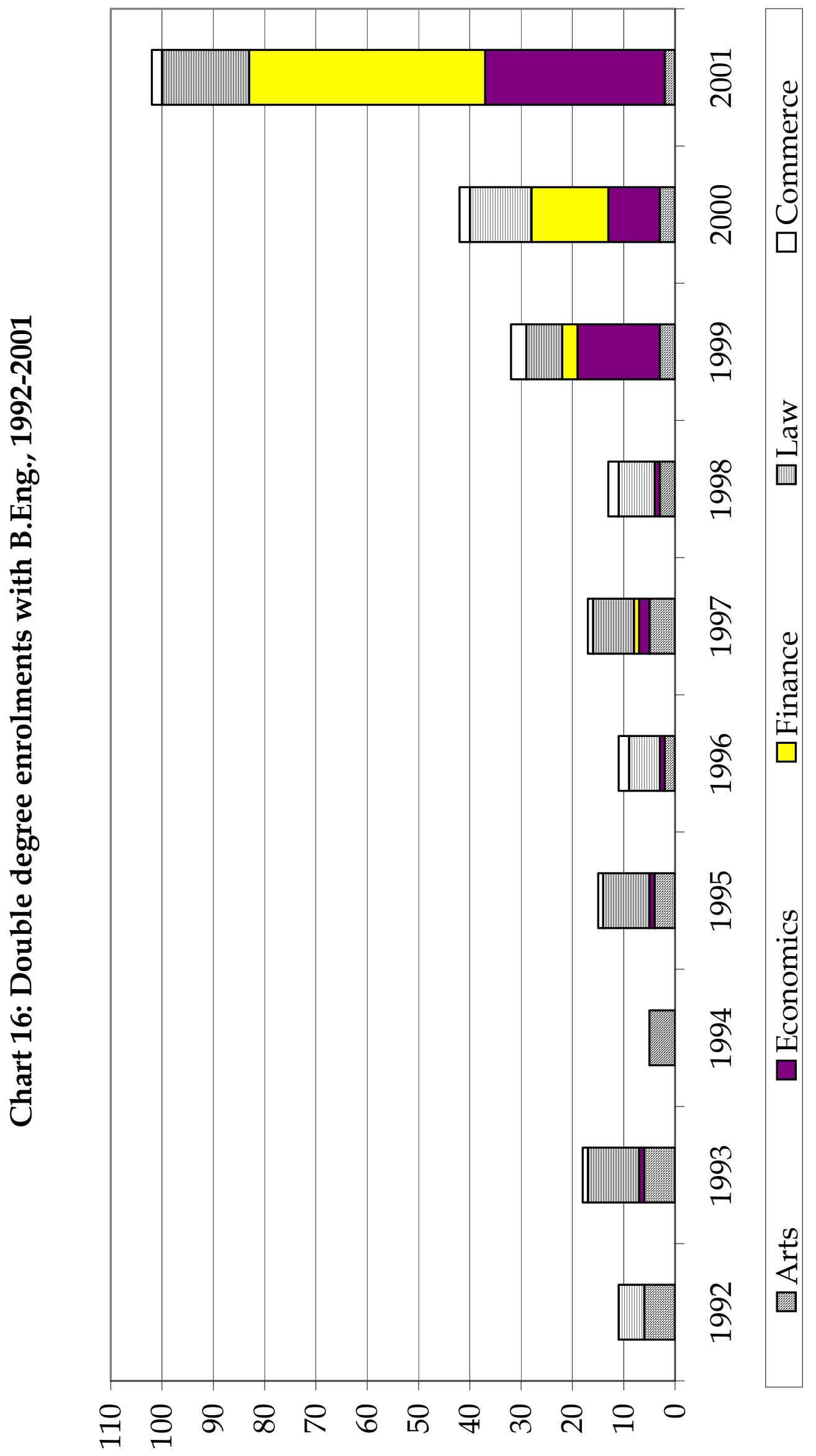





\section{Appendix 3: Tables}

Page

Table 1: Alphabetical list of full-time Economics Lecturers, with years of service, 1901-2002

Table 2: Full-time Economics Lecturers by level of 93 appointment and start date, 1901-2003

Table 3: Number of full-time Economics Lecturers at 106 each level, by year, 1901-2003

Table 4: $\quad$ Titled, Emeritus and Adjunct Professors, 1959108 2003

Table 5: Lecturers elected Fellows (and Presidents) of the 109 learned academics, 1952-2002

Table 6: Lecturers who became chaired Professors (and 110 Vice-Chancellors), by initial level of appointment at Adelaide, 1901-2002

Table 7: Alphabetical list of Ph.D. graduates, 1971-2003

Table 8: Titles of theses of Ph.D. graduates, by year of graduation, 1971-2003

Table 9: $\quad$ Alphabetical list of Masters graduates, 1950-2002

Table 10: Titles of theses of Masters graduates, by year of 120 graduation, 1950-2002

Table 11: Alphabetical list of Honours graduates, 19452002

Table 12: Titles of theses of Honours graduates, by year of graduation, 1945-2002

Table 13: Alphabetical list of students completing a Graduate Certificate, Graduate Diploma or Applied Masters, 1990-2002

Table 14: Rhodes Scholars with a University of Adelaide 173 major in Economics, 1938-2003 
Table 15: University awards in economics and commerce, 174 1901-2002

Table 16: Undergraduate graduations in economics and 175 commerce, by award, 1904-1957

Table 17: Number of new B.Ec., B.Fin., M.Ec. and Ph.D. graduates, by award, 1945-2003

Table 18: Number of other new Economics-related graduates, by award, 1989-2003

Table 19: South Australian Centre for Economic Studies staff, 1982-2002

Table 20: Centre for International Economic Studies staff, 1989-2003

Table 21: Chinese Economies Research Centre staff, 19901999

Table 22: The Joseph Fisher Lectures and lecturers, 19042003

Table 23: Deans, Assistants and Librarians of the Faculty and Schools of Economics, Commerce and Graduate Business, 1946-2002

Table 24: Number of Lecturers E, D and B-E in Australian 192 teaching Departments of Economics with more than two Professors, 1987 and 2002

Table 25: Average completion times for Ph.D. and Masters theses, 1948-2002

Table 26: School/Department of Economics working papers, 1970-2002

Table 27: South Australian Centre for Economic Studies working papers and monographs, 1982-2002

Table 28: Centre for International Economic Studies 208 working papers and monographs, 1989-2002

Table 29: Chinese Economies Research Centre working 239 papers, 1990-1999 


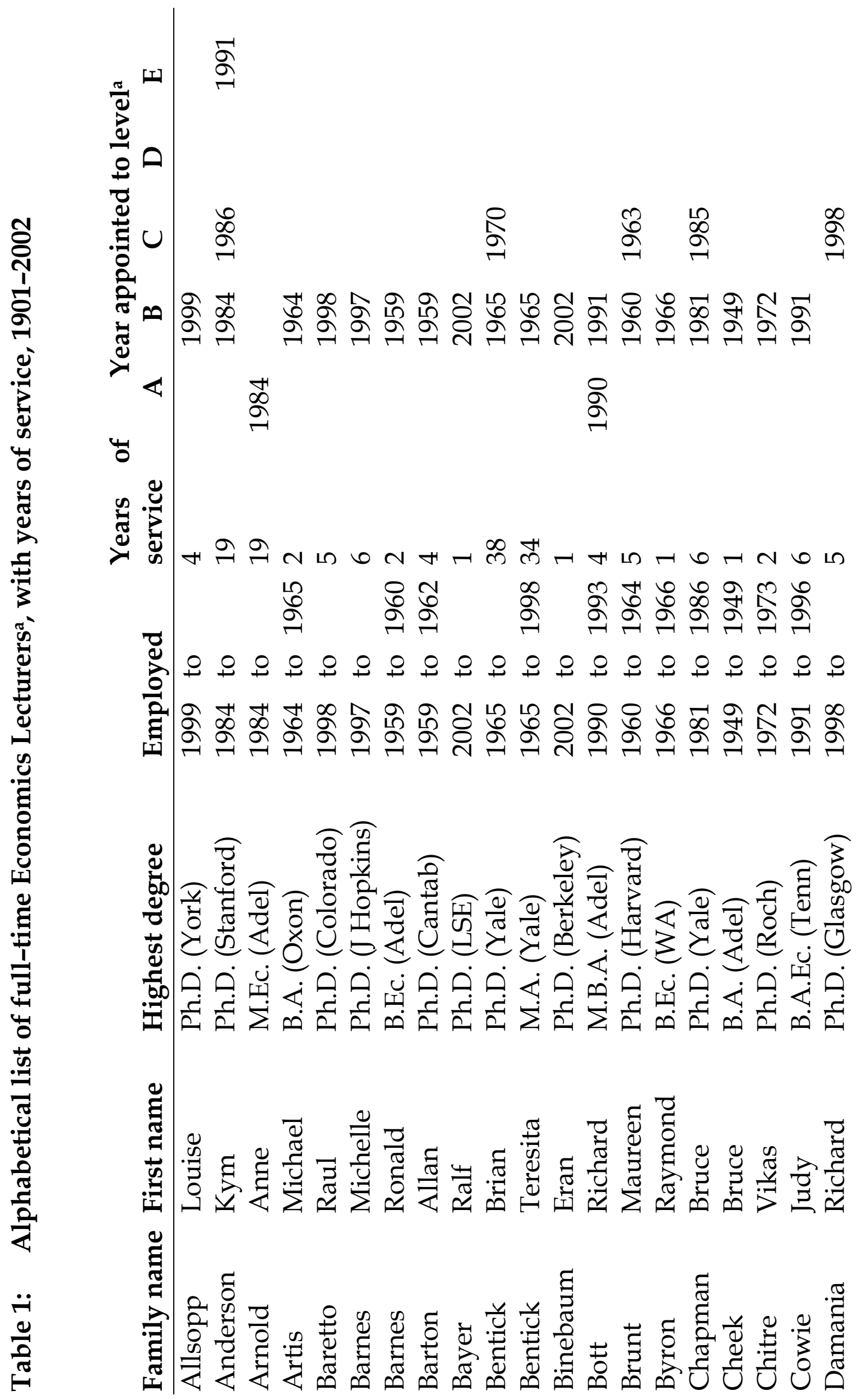




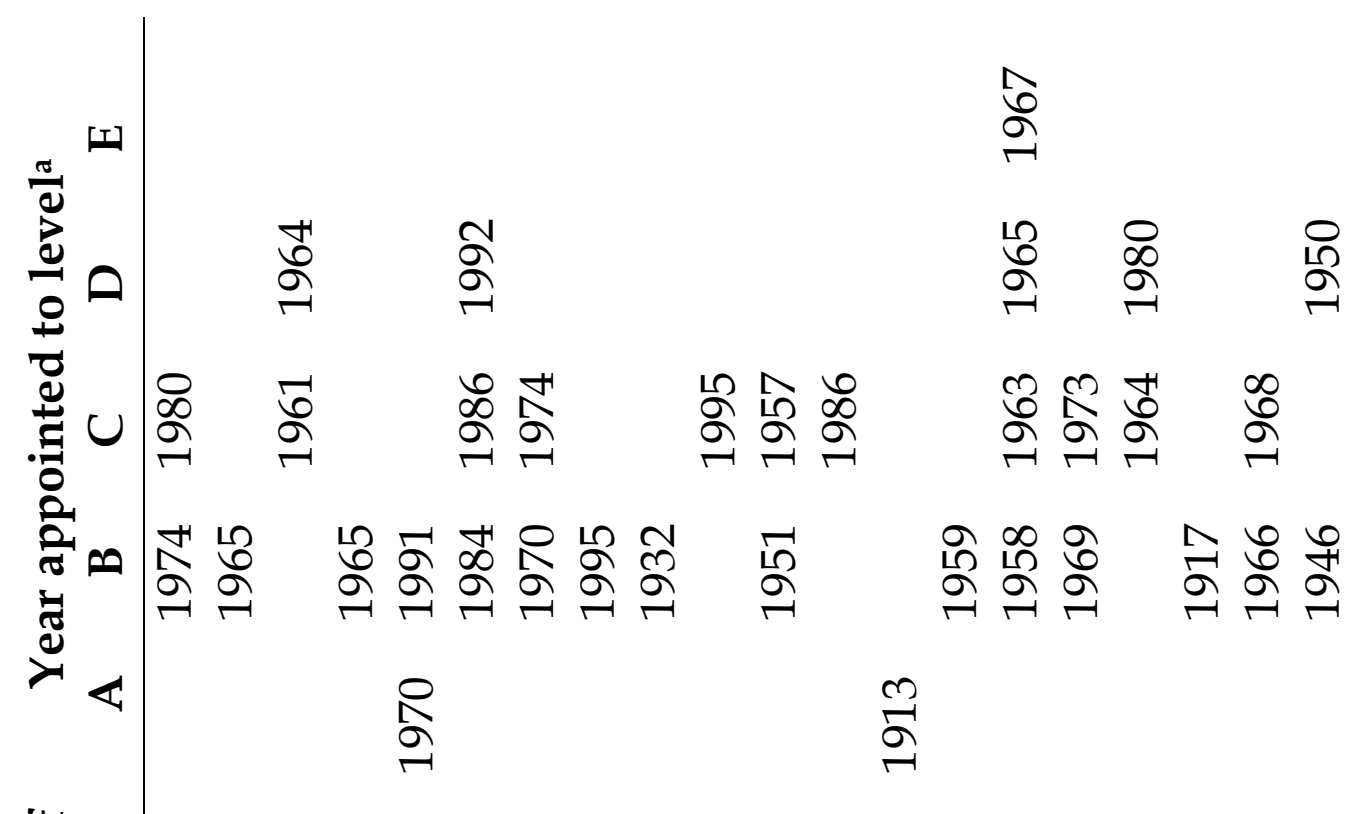

¿্ৰ

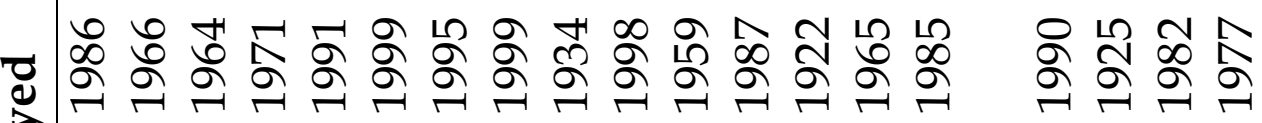
는 1

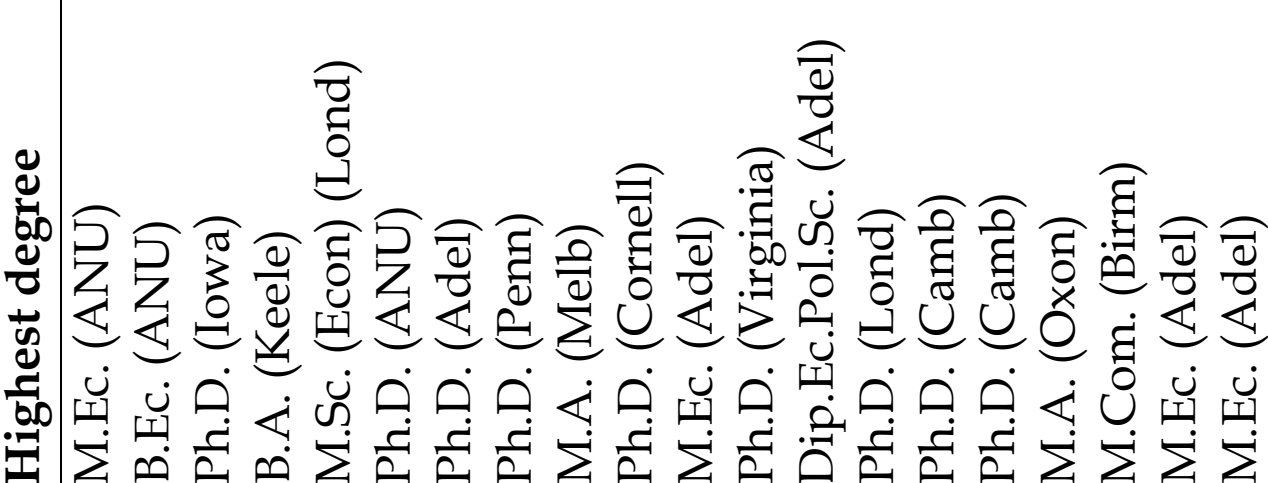

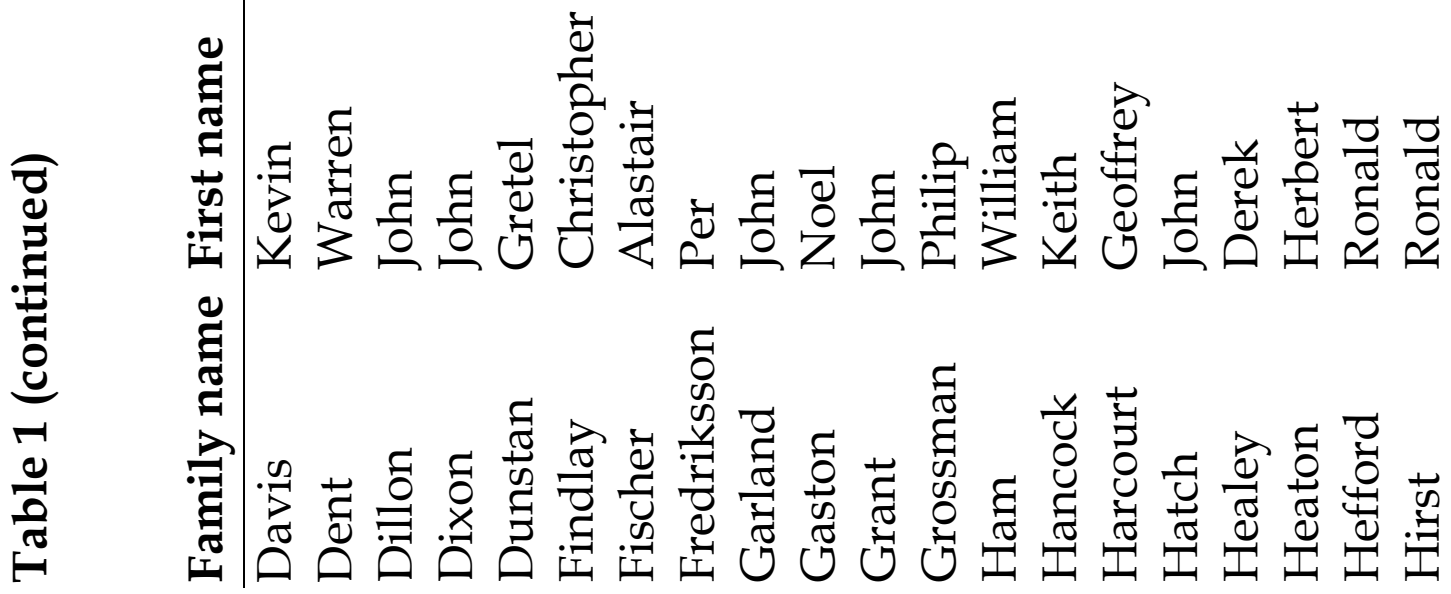




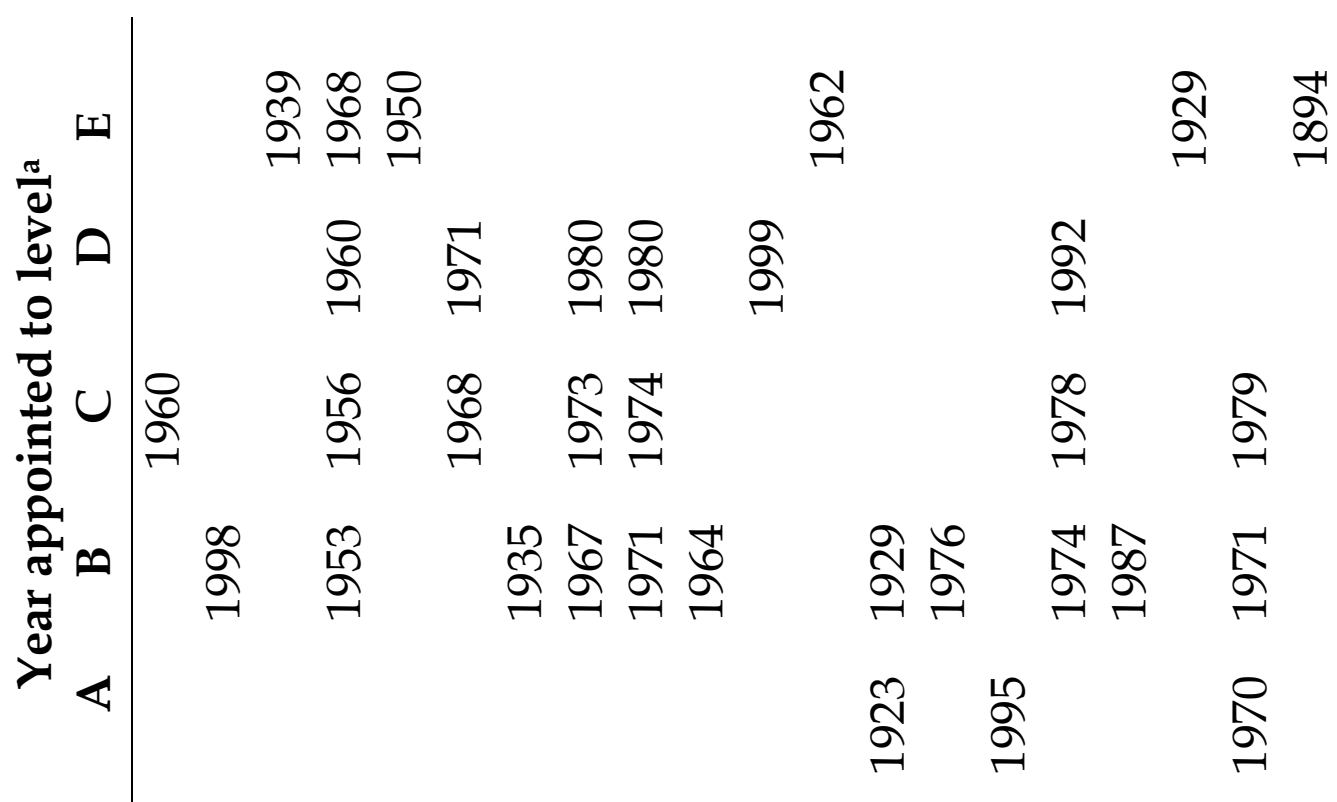

¿্ৰ

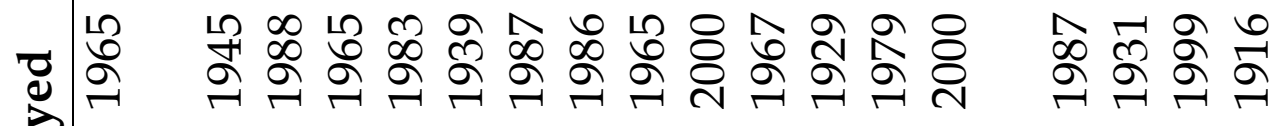

늘

兟

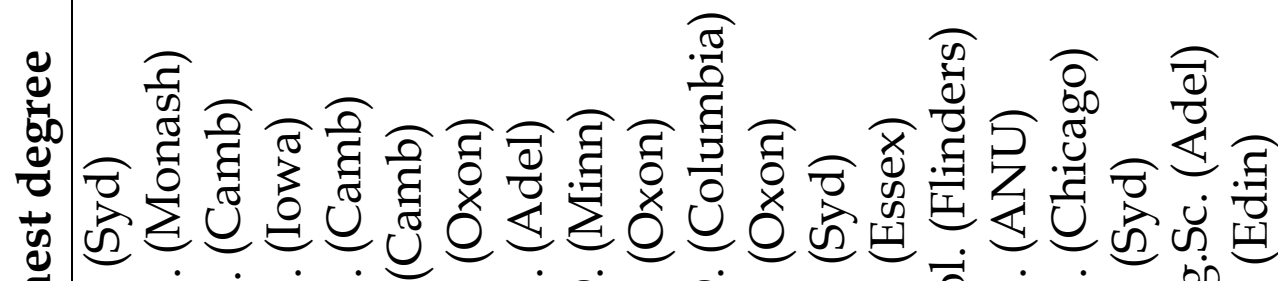



i

苞 


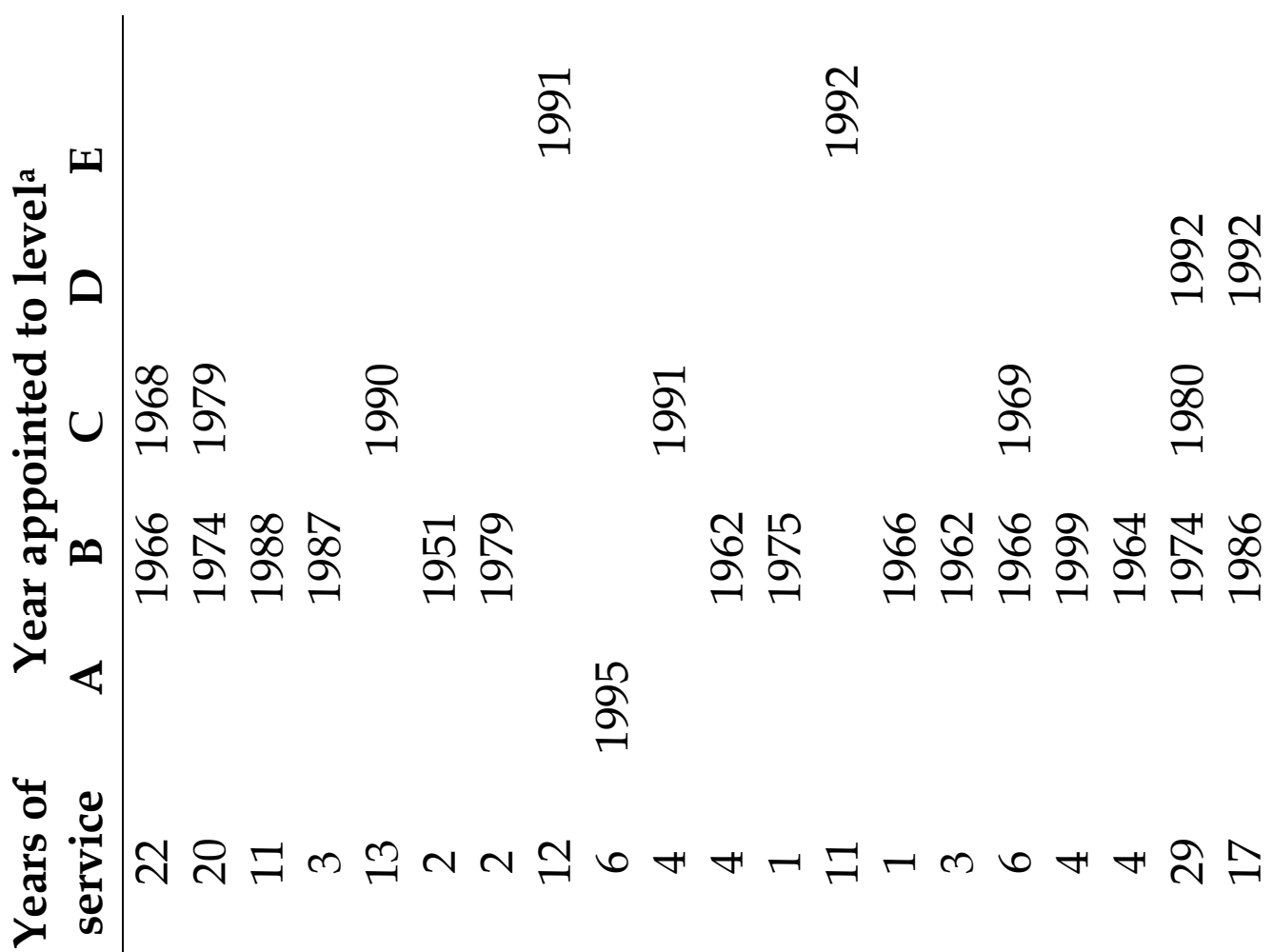

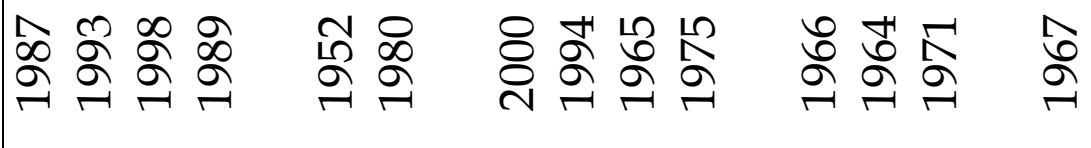
ช

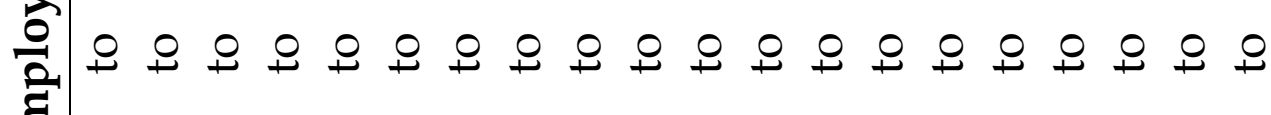

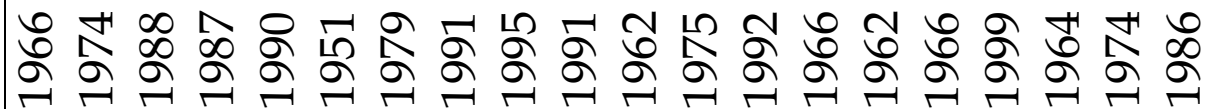

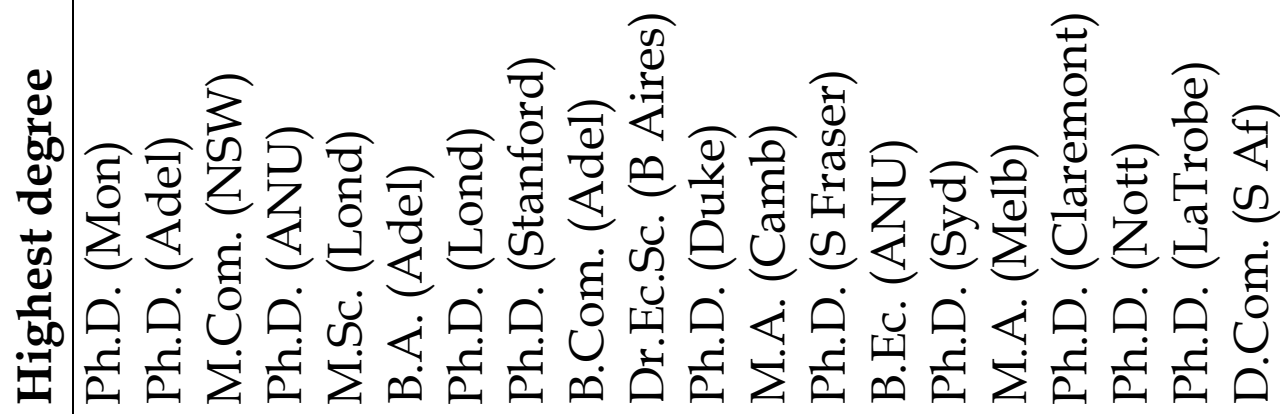

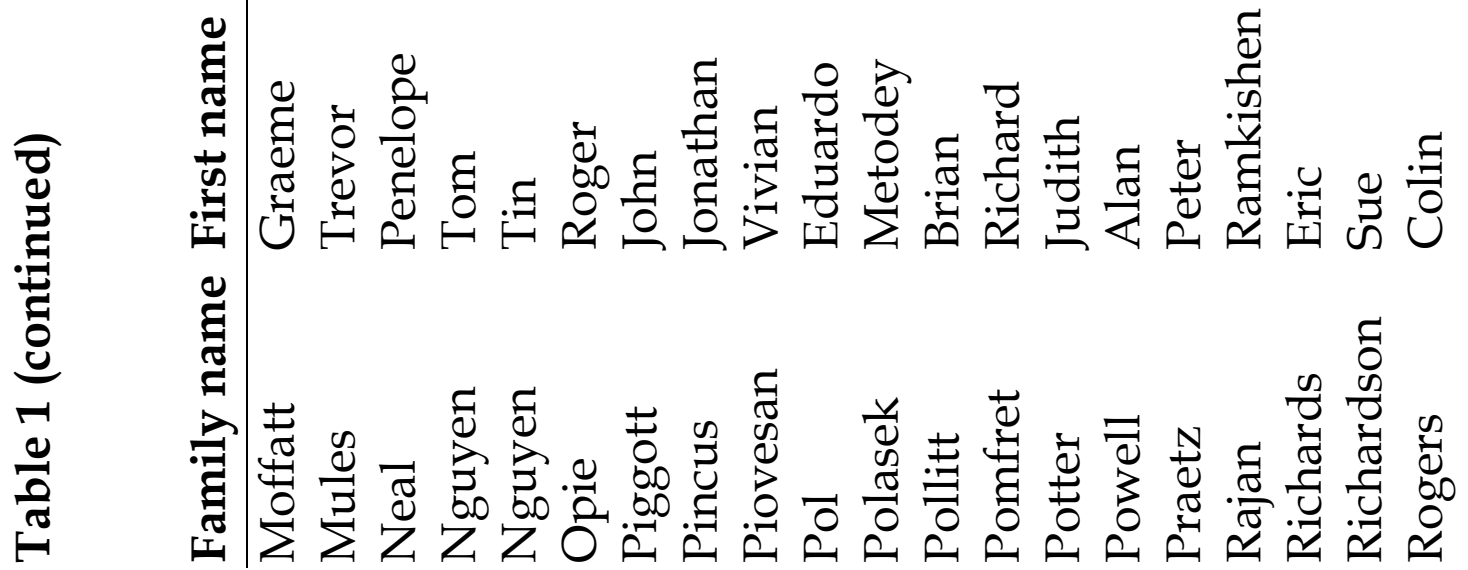




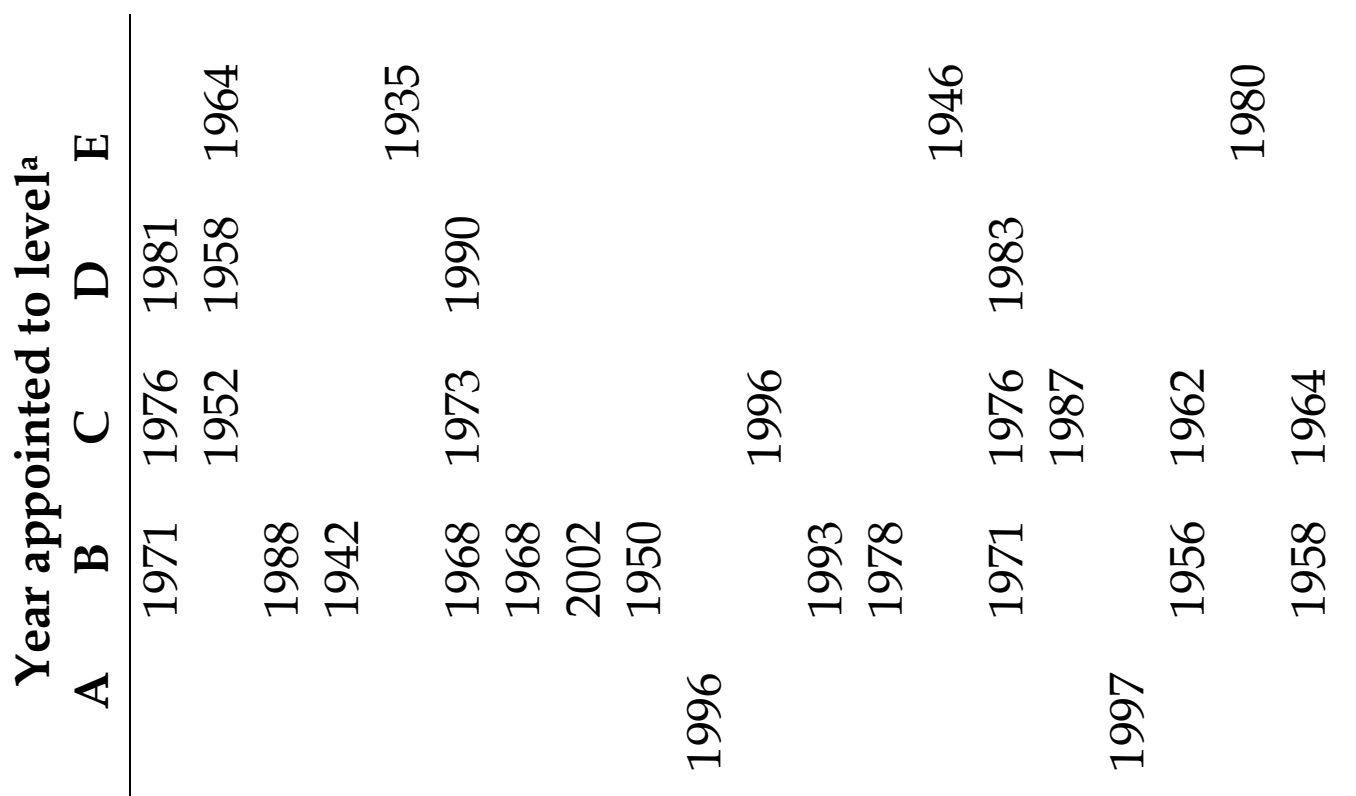

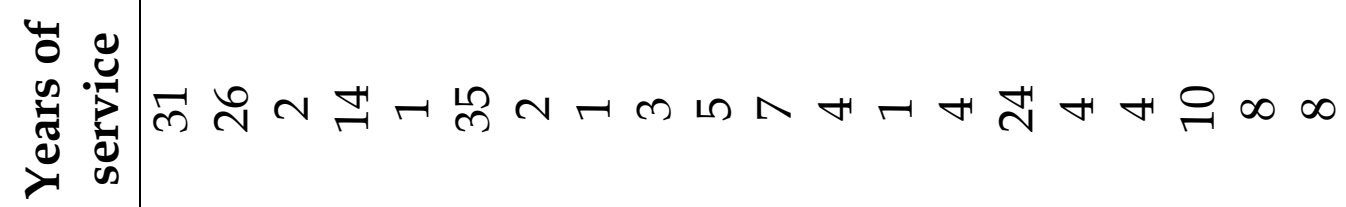

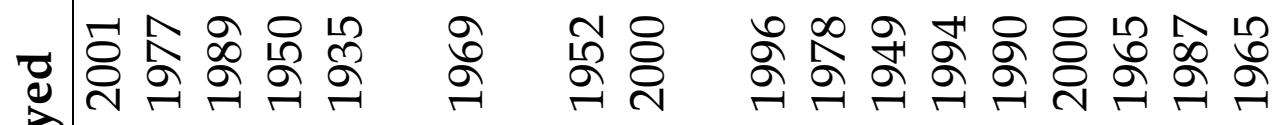

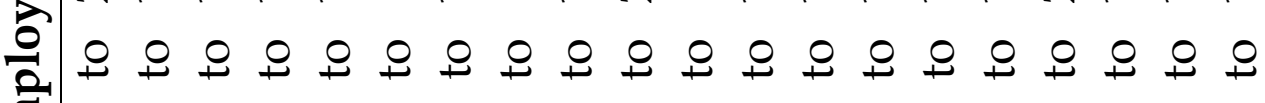

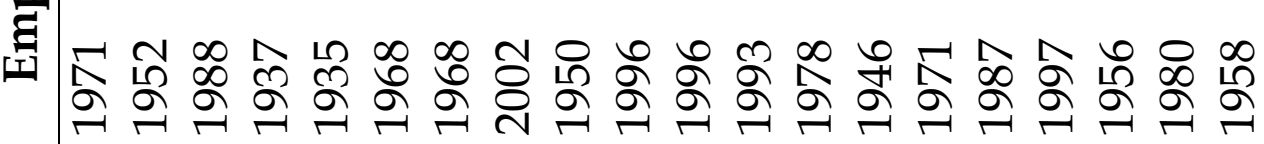

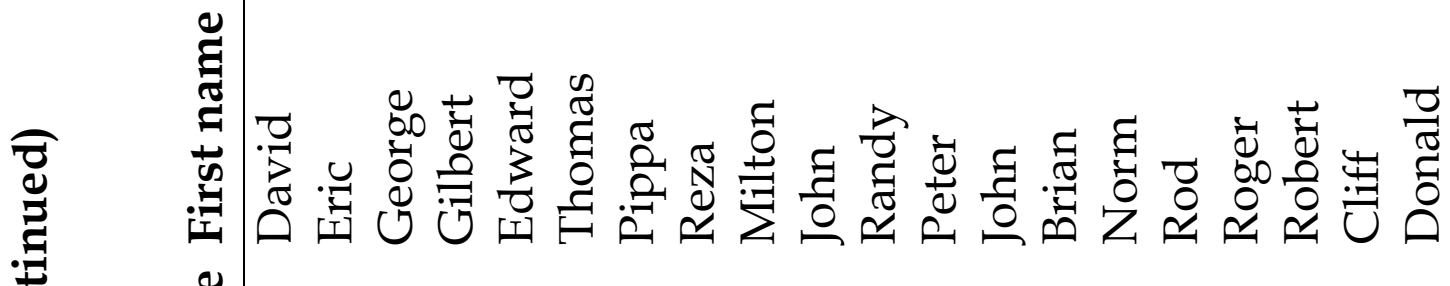

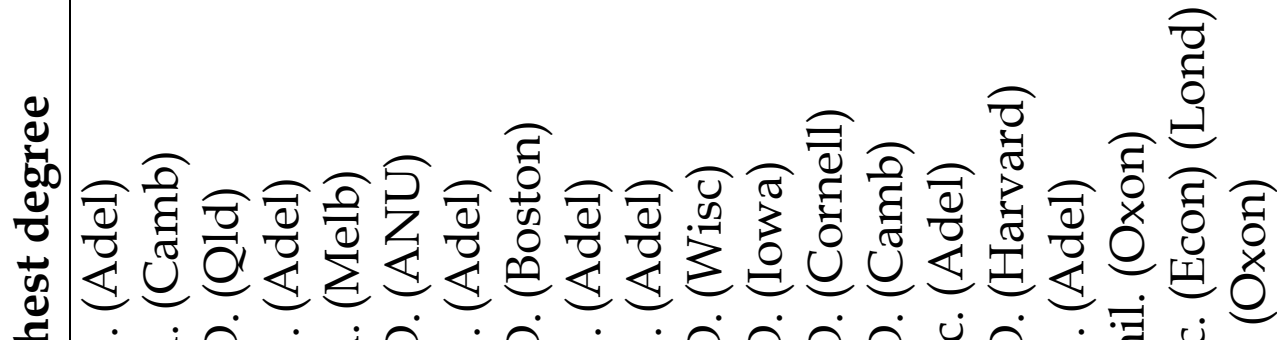

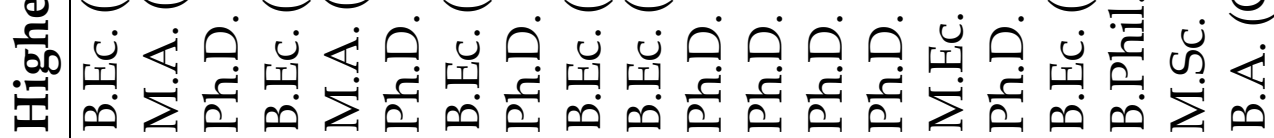

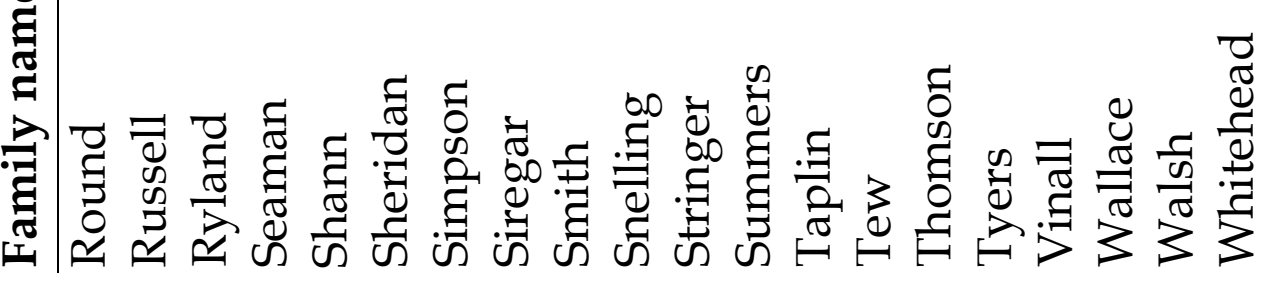




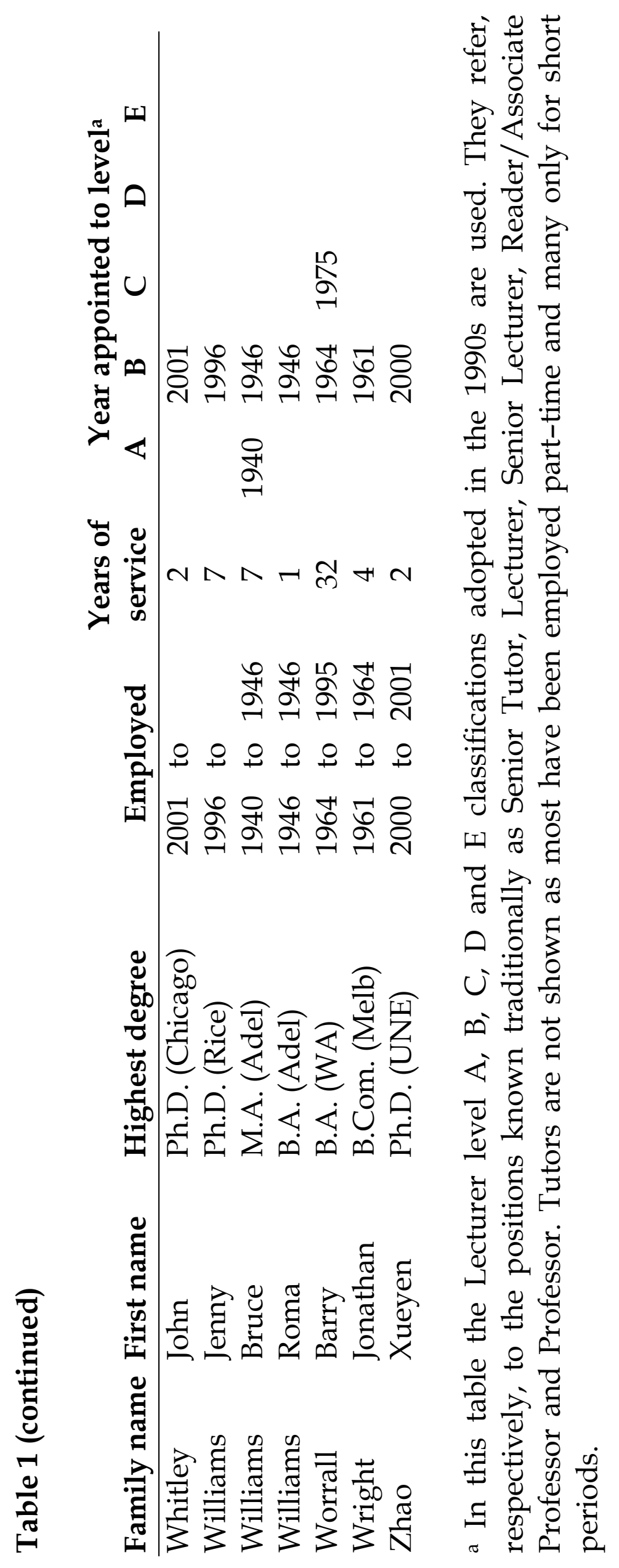




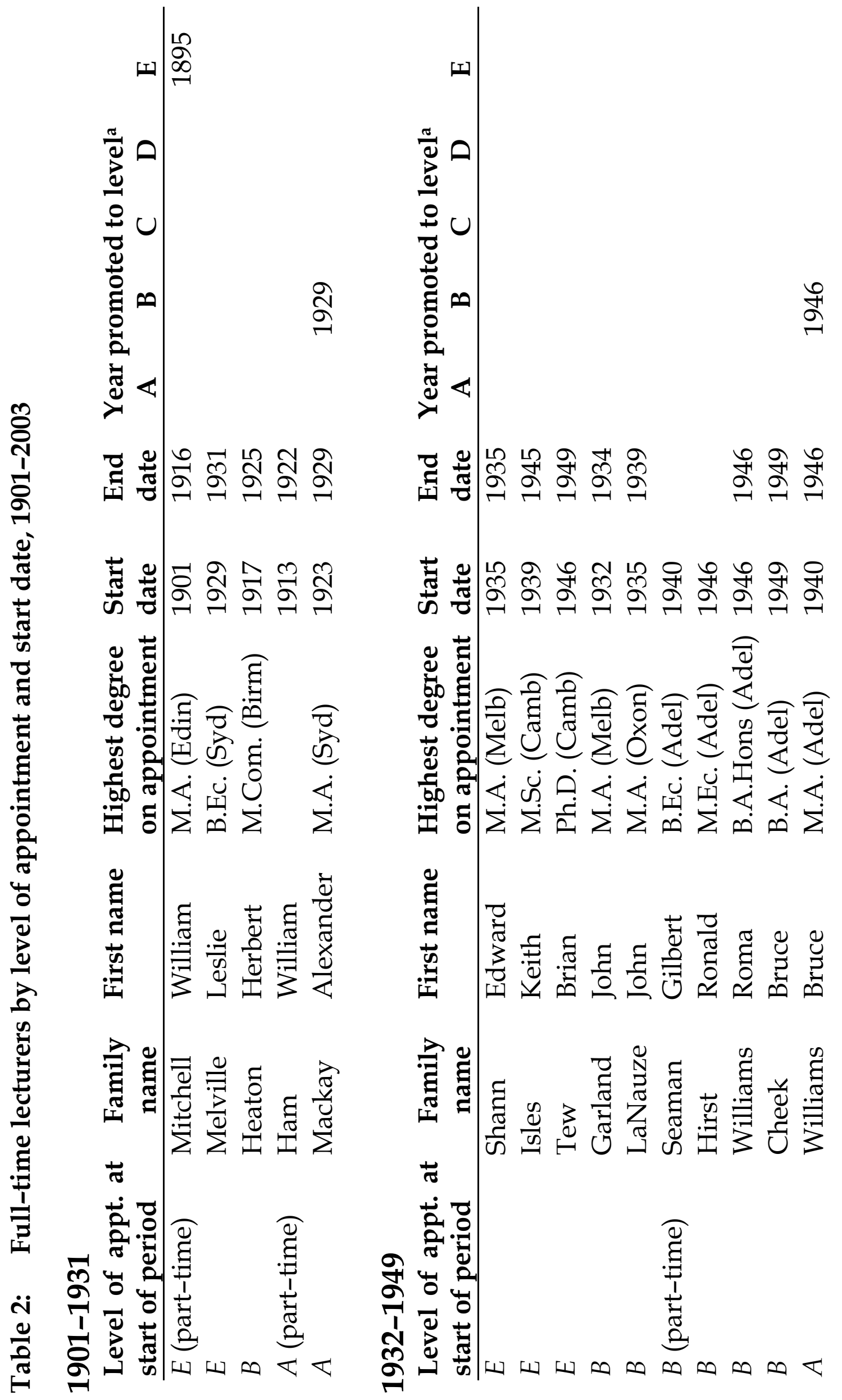




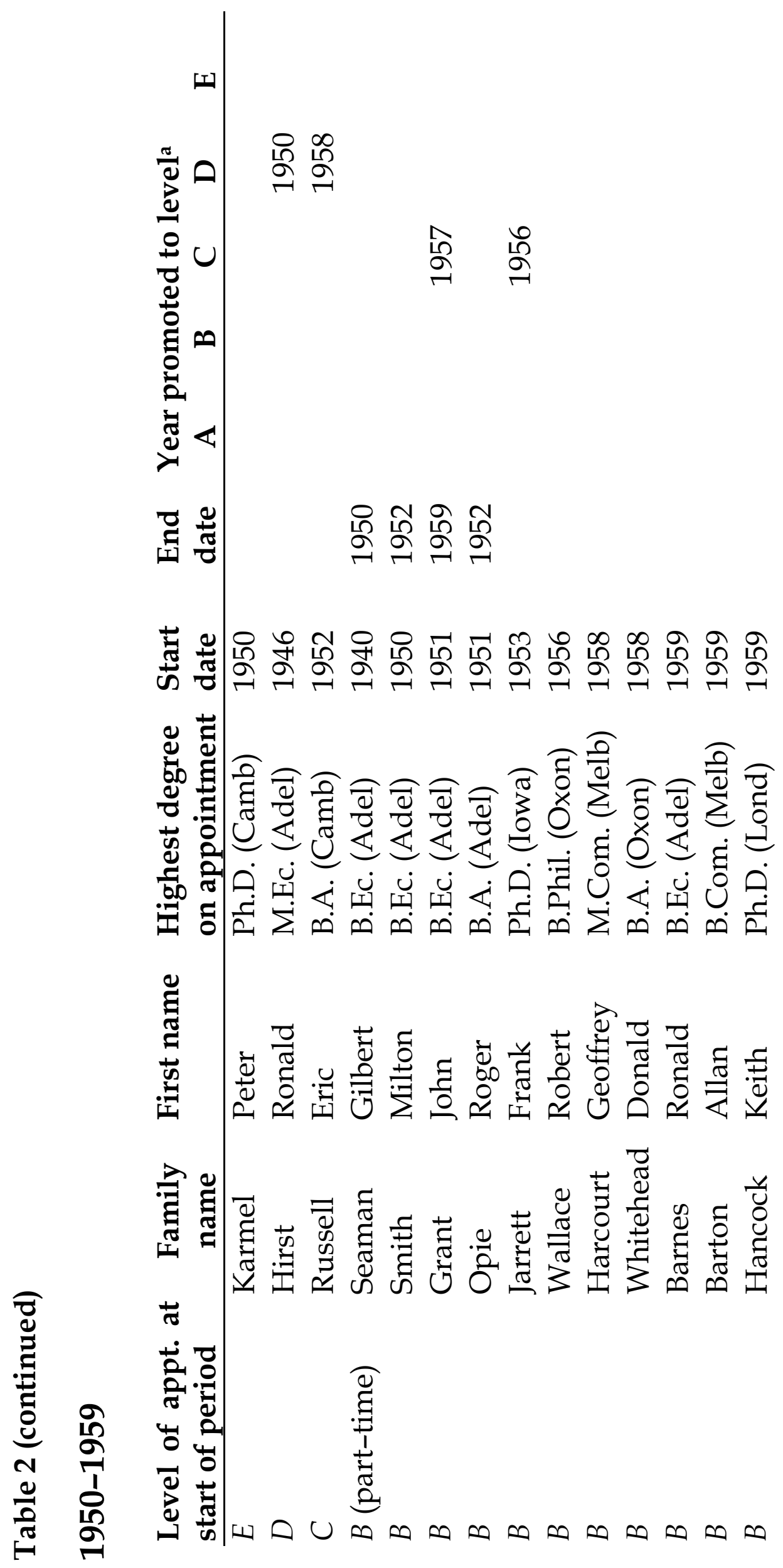




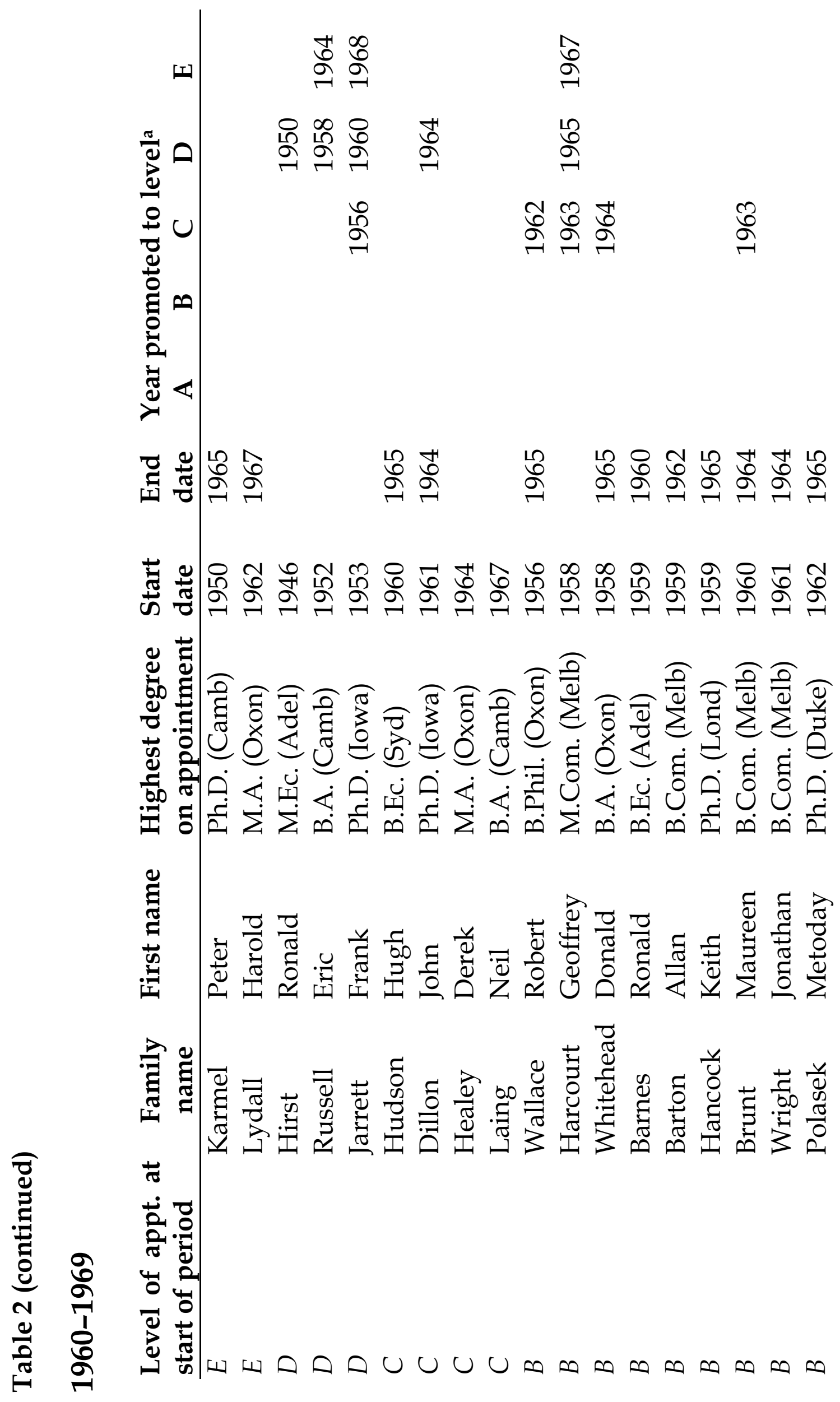




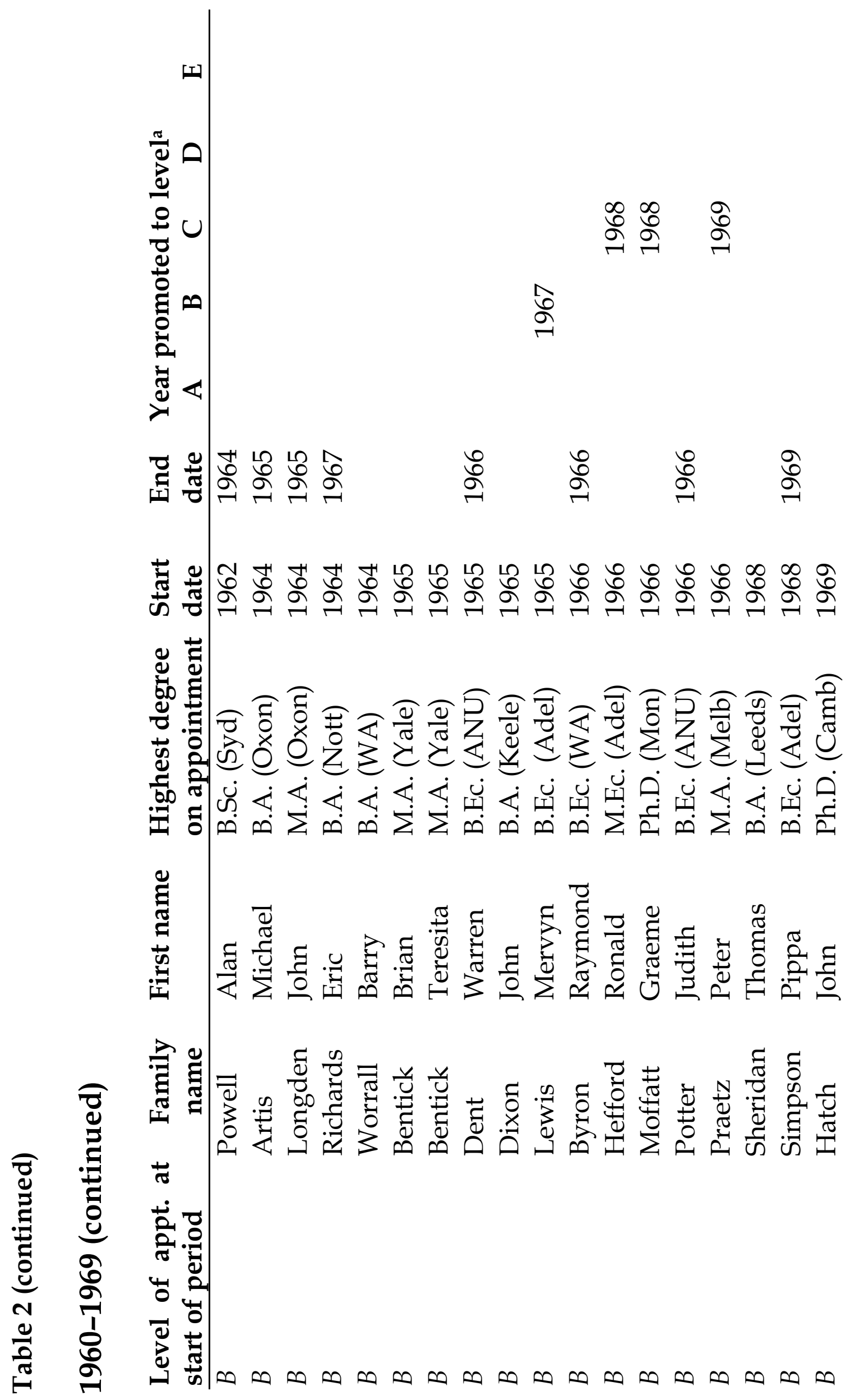




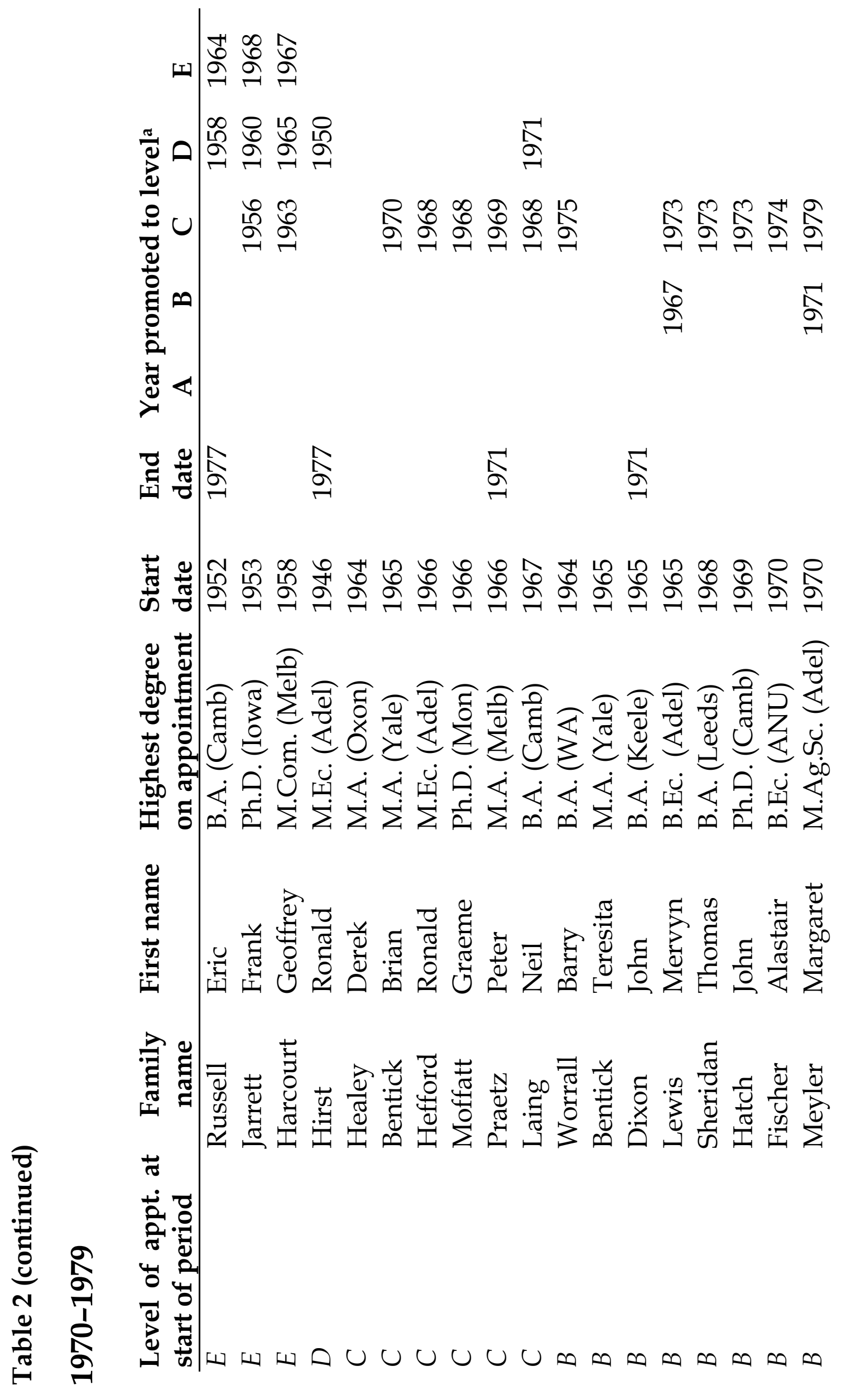




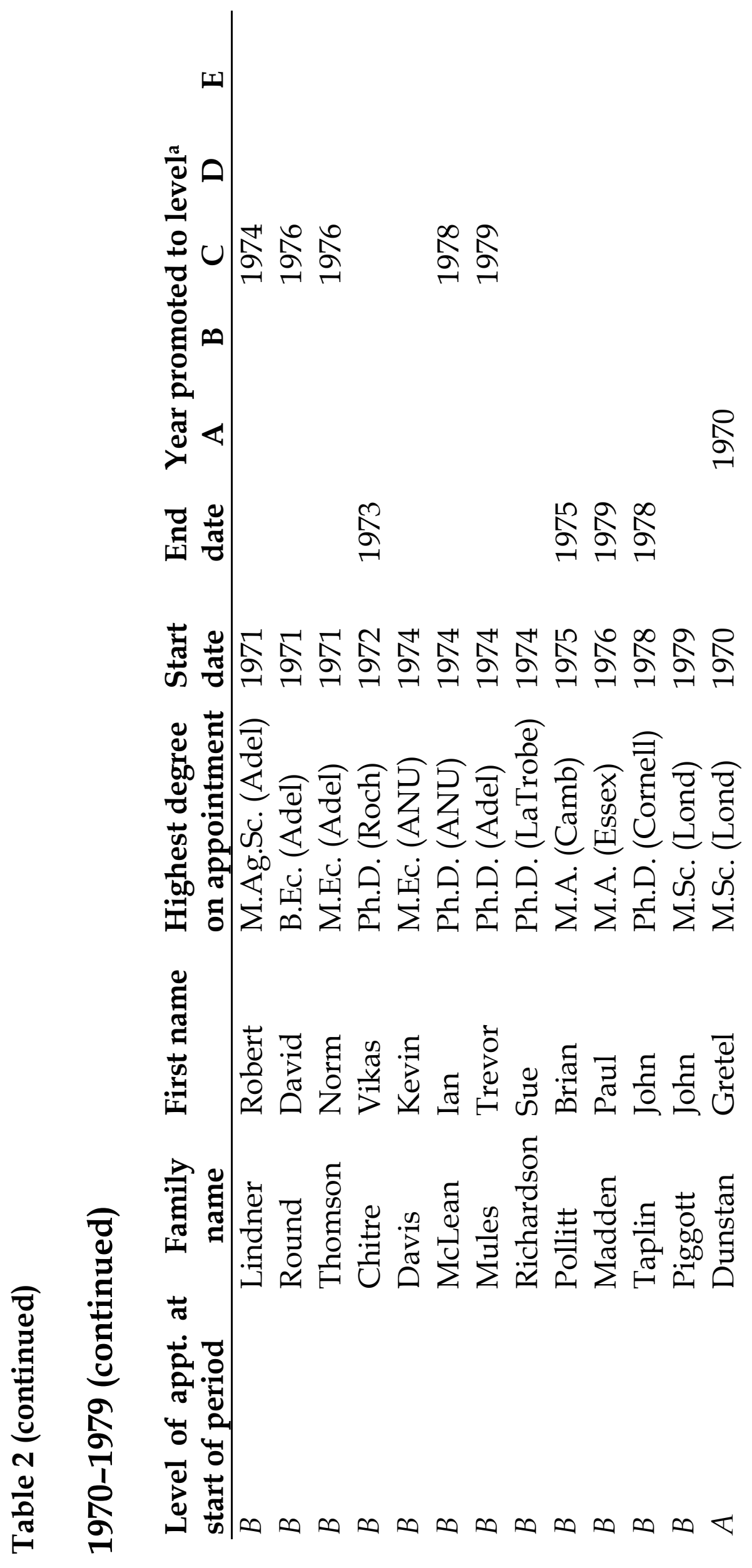




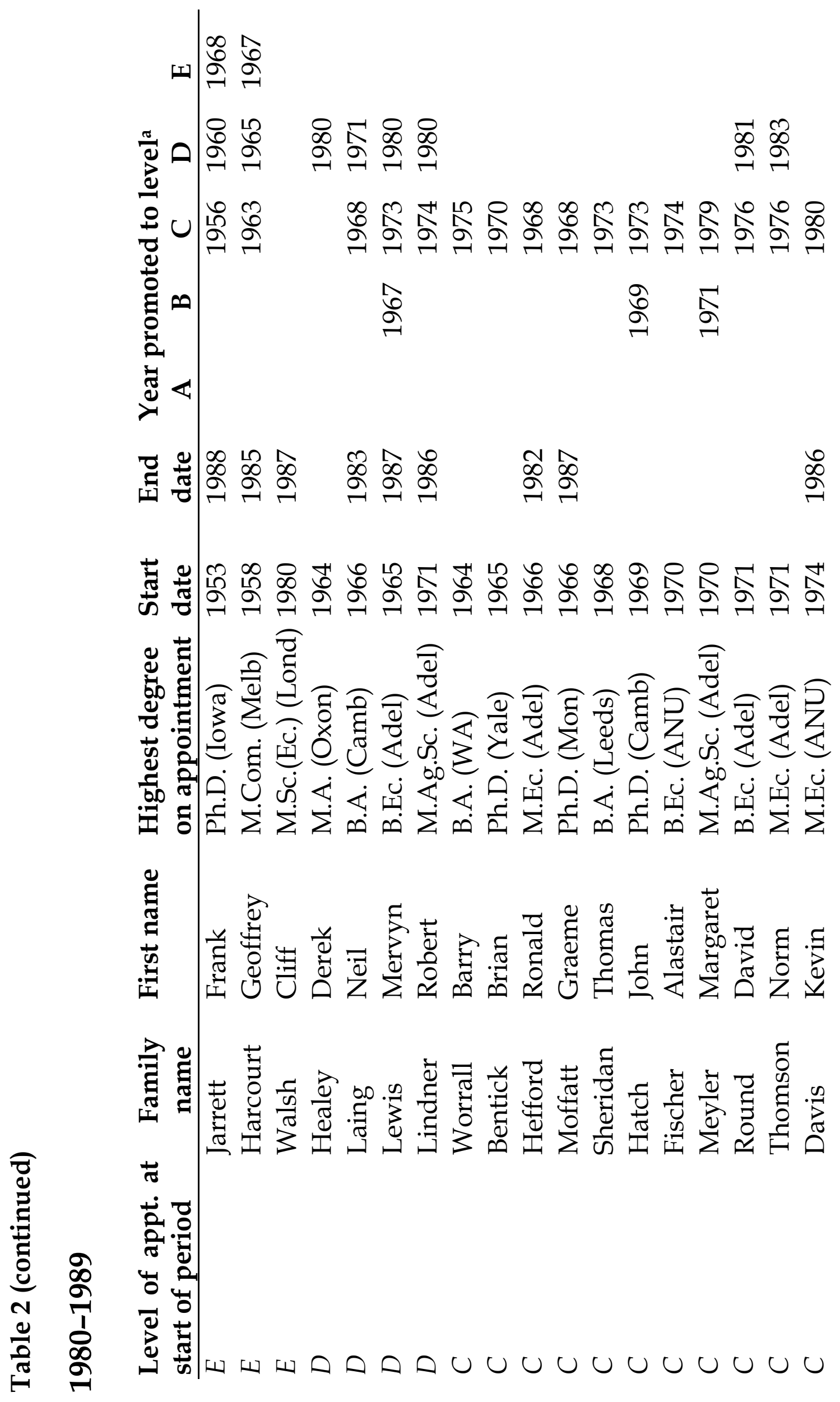




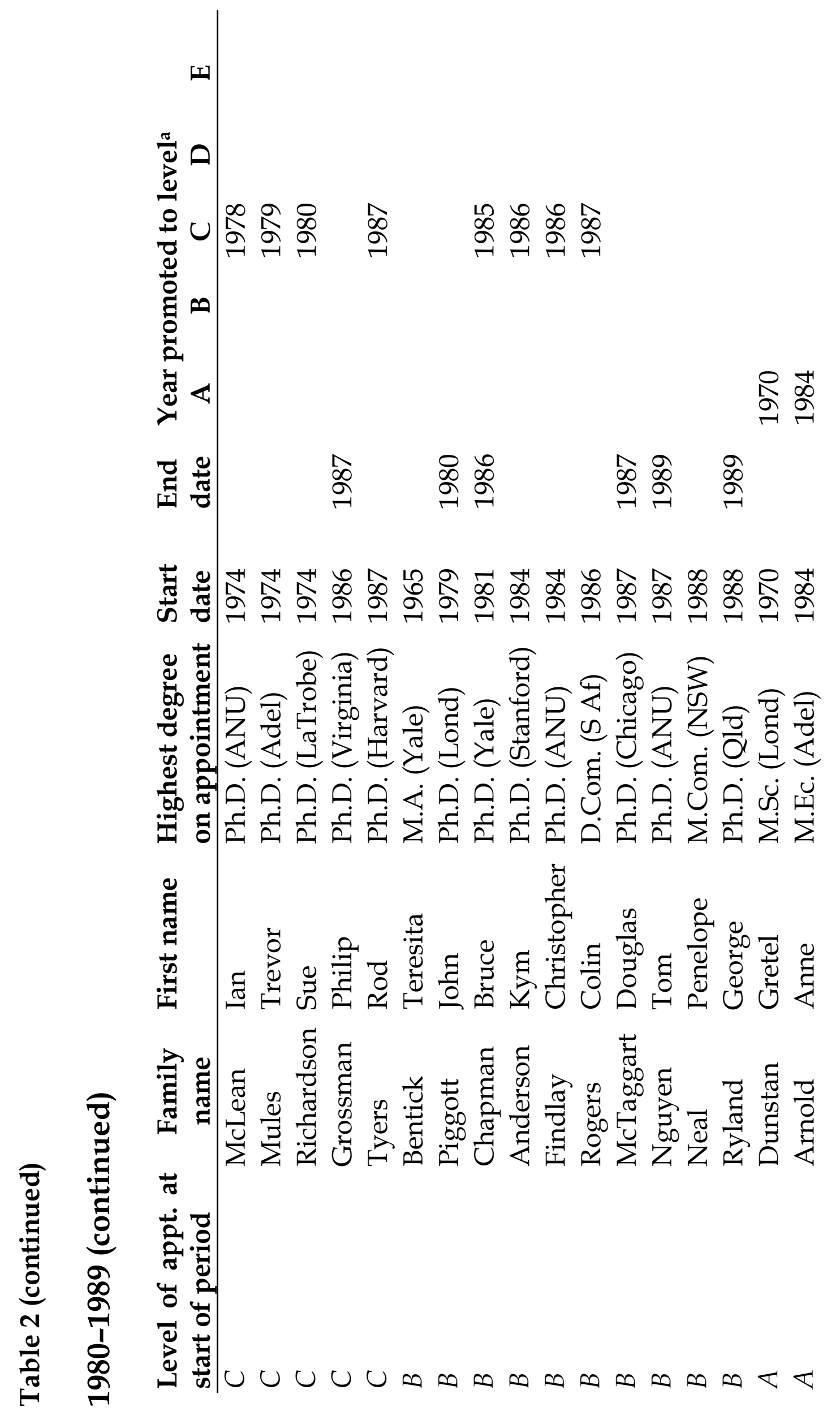




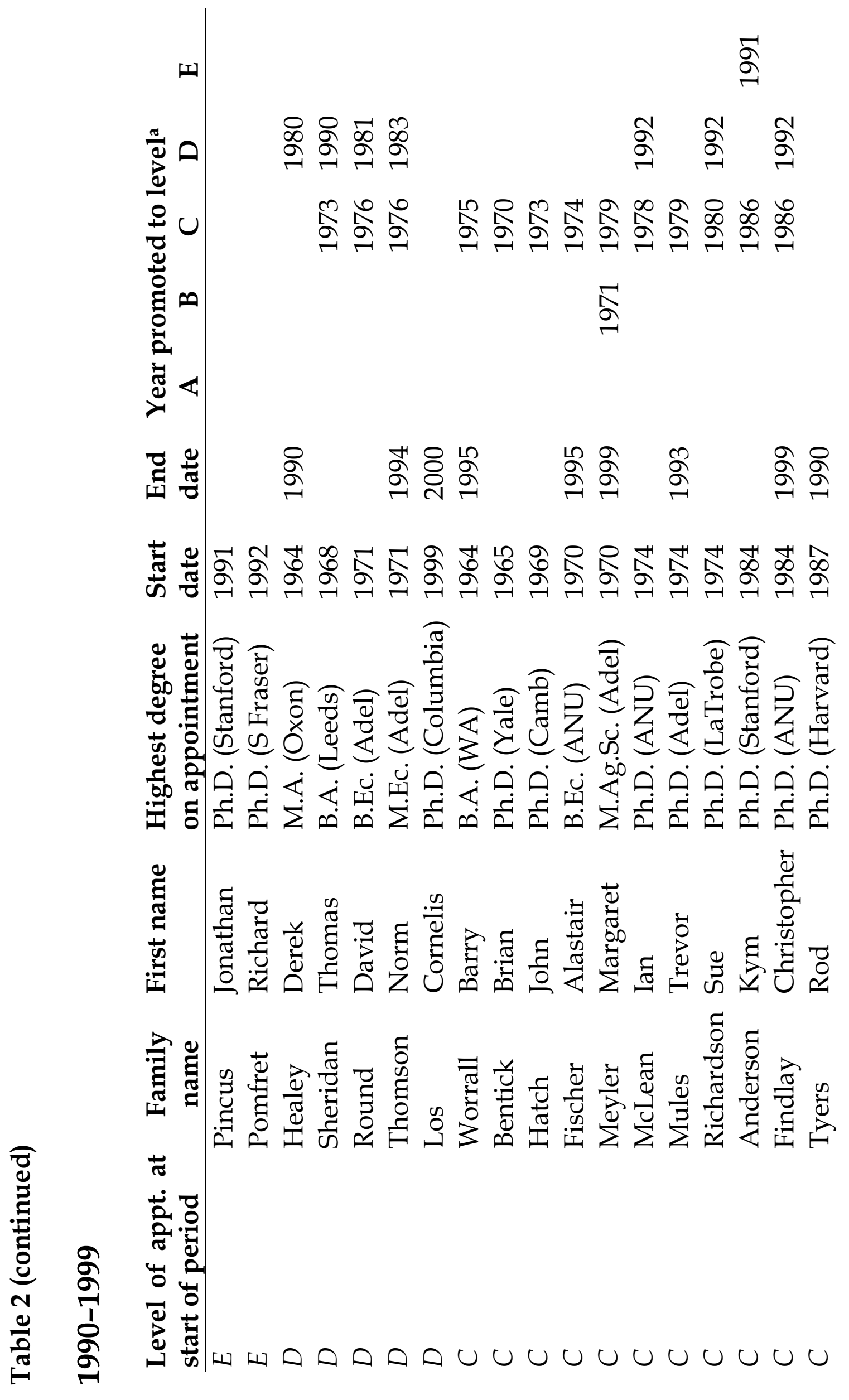




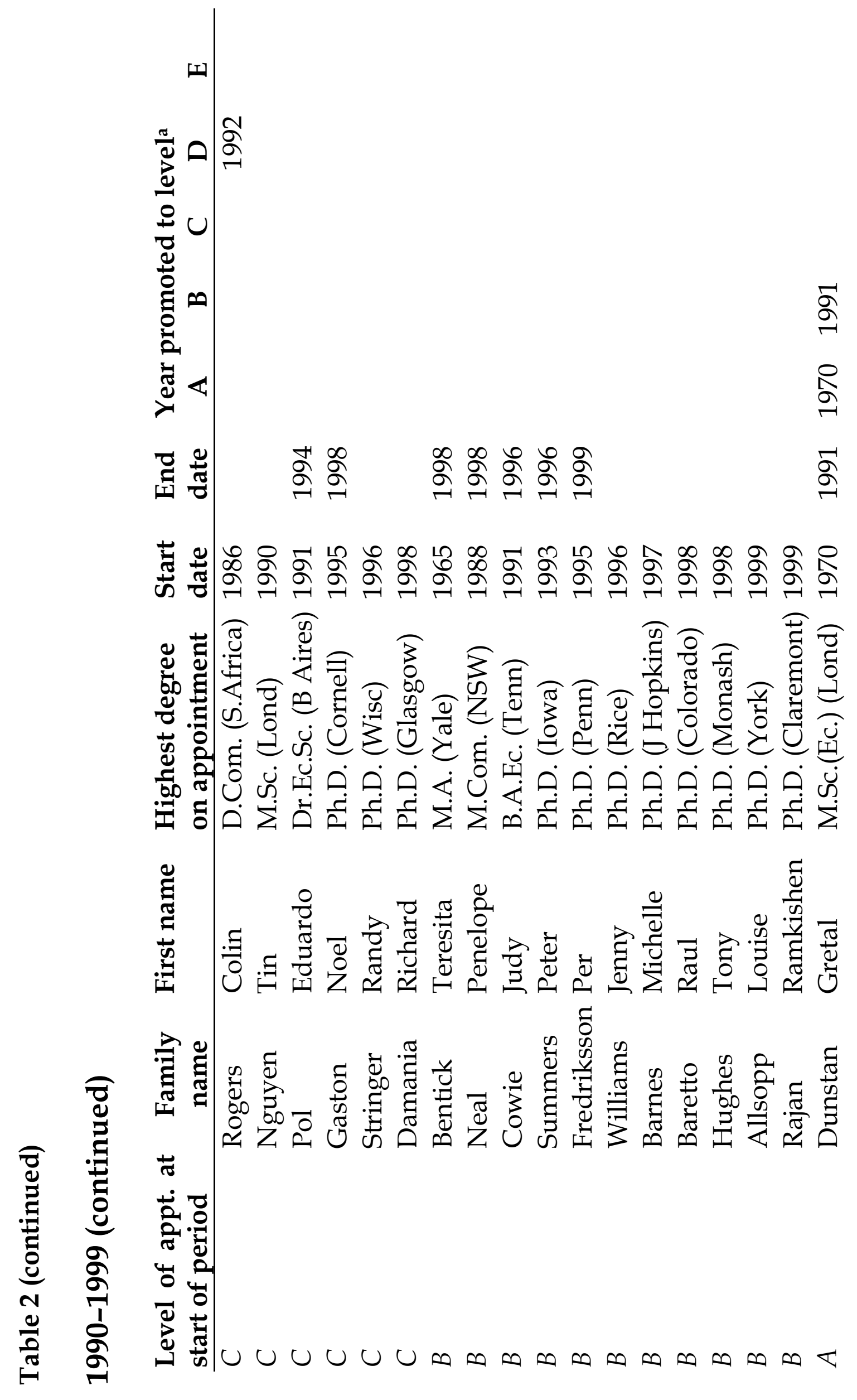




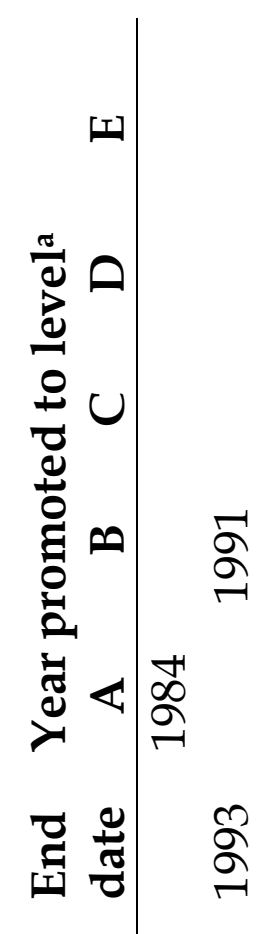

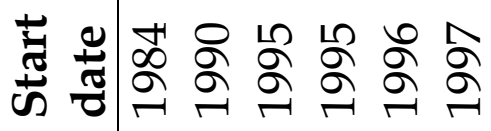

巳 d

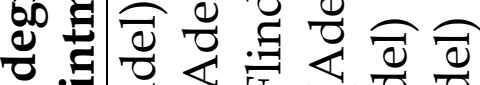

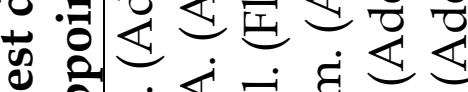

की

江

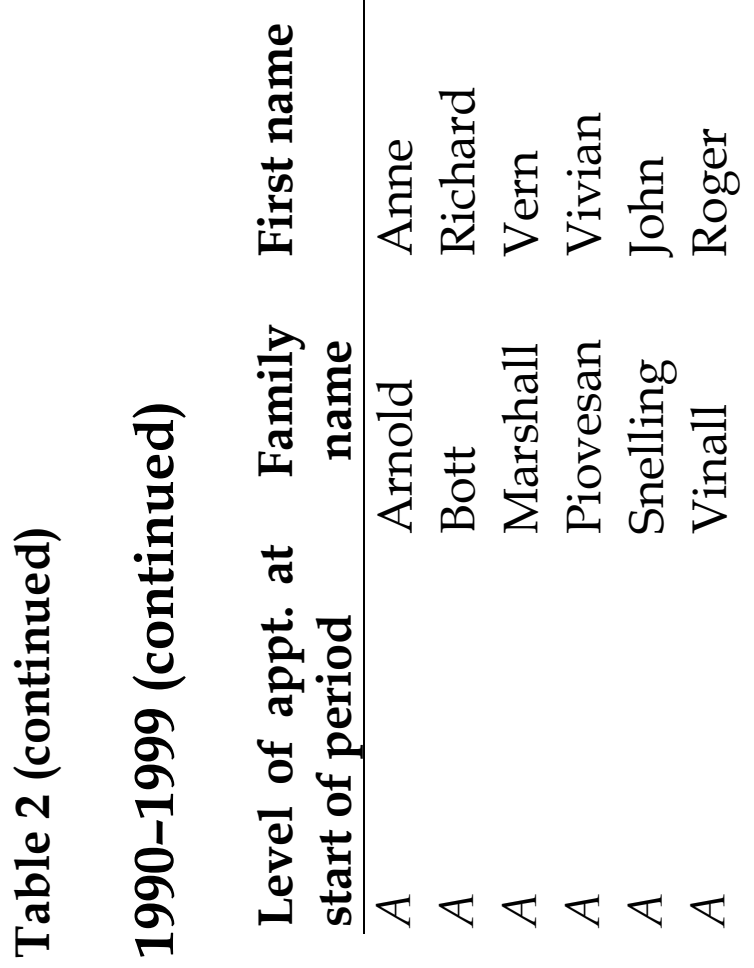




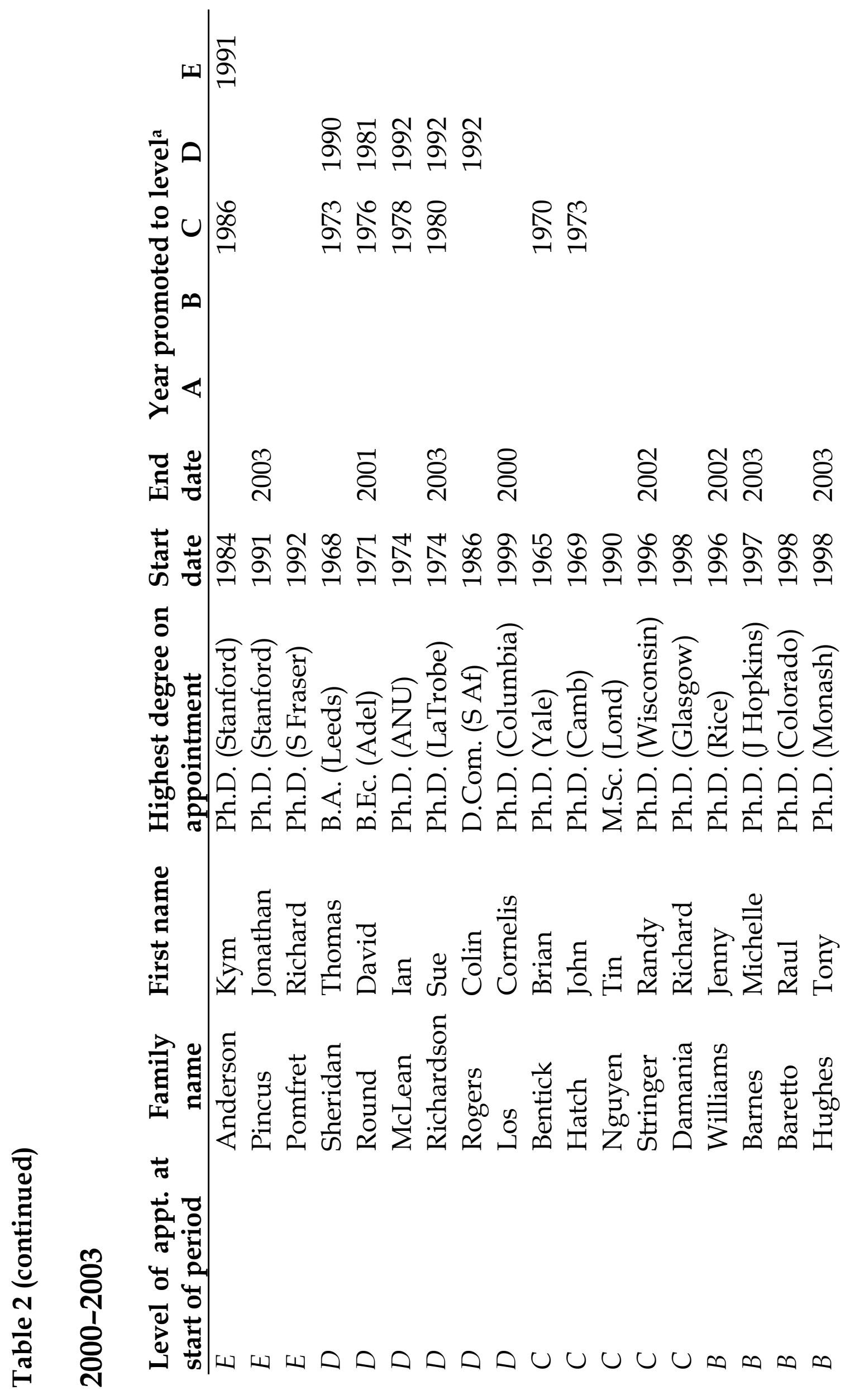




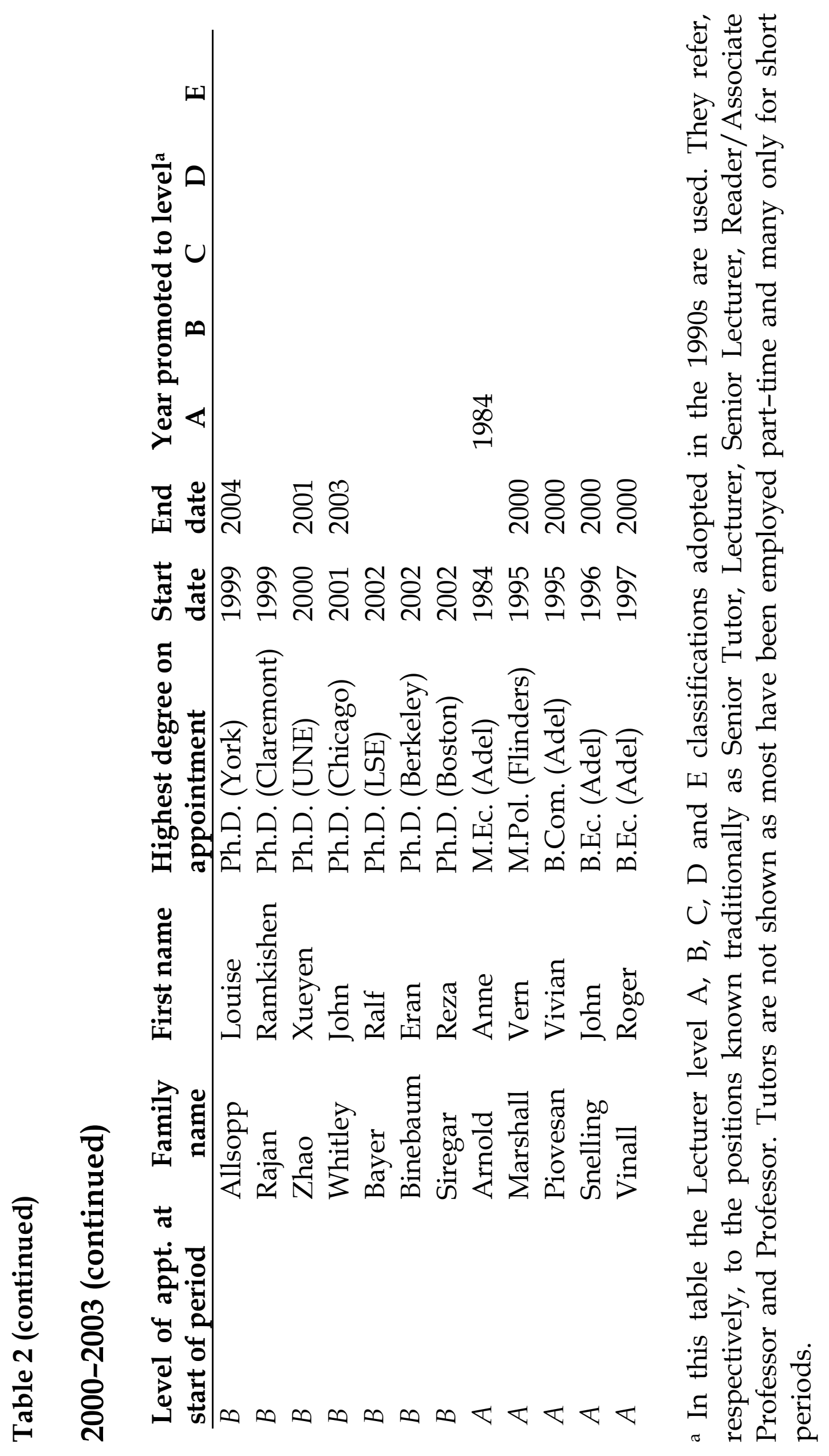


Table 3 (continued)

\begin{tabular}{lllllll} 
Year & A & B & C & D & E & Total \\
\hline 1969 & & 7 & 6 & 1 & 3 & 17 \\
1970 & 1 & 8 & 6 & 1 & 3 & 19 \\
1971 & 1 & 11 & 5 & 2 & 3 & 22 \\
1972 & 1 & 11 & 4 & 2 & 3 & 21 \\
1973 & 1 & 8 & 9 & 2 & 3 & 23 \\
1974 & 1 & 8 & 10 & 2 & 3 & 24 \\
1975 & 1 & 9 & 11 & 2 & 3 & 26 \\
1976 & 1 & 7 & 12 & 2 & 3 & 25 \\
1977 & 1 & 7 & 12 & 2 & 3 & 25 \\
1978 & 1 & 7 & 13 & 1 & 2 & 24 \\
1979 & 1 & 4 & 16 & 1 & 2 & 24 \\
1980 & 1 & 2 & 14 & 4 & 3 & 24 \\
1981 & 1 & 2 & 13 & 5 & 3 & 24 \\
1982 & 1 & 2 & 13 & 5 & 3 & 24 \\
1983 & 1 & 2 & 11 & 6 & 3 & 23 \\
1984 & 2 & 4 & 11 & 5 & 3 & 25 \\
1985 & 2 & 4 & 11 & 5 & 3 & 25
\end{tabular}

\begin{tabular}{lllllll} 
Year & A & B & C & D & E & Total \\
\hline 1986 & 2 & 3 & 14 & 5 & 2 & 26 \\
1987 & 2 & 3 & 15 & 4 & 2 & 26 \\
1988 & 2 & 4 & 13 & 3 & 1 & 23 \\
1989 & 2 & 4 & 13 & 3 & & 22 \\
1990 & 3 & 2 & 13 & 4 & & 22 \\
1991 & 1 & 5 & 12 & 3 & 2 & 23 \\
1992 & 1 & 4 & 8 & 7 & 3 & 23 \\
1993 & 1 & 5 & 8 & 7 & 3 & 24 \\
1994 & 1 & 4 & 7 & 7 & 3 & 22 \\
1995 & 3 & 5 & 7 & 6 & 3 & 24 \\
1996 & 4 & 6 & 6 & 6 & 3 & 25 \\
1997 & 5 & 5 & 6 & 6 & 3 & 25 \\
1998 & 5 & 7 & 7 & 6 & 3 & 28 \\
1999 & 5 & 7 & 6 & 7 & 3 & 28 \\
2000 & 5 & 7 & 5 & 6 & 3 & 26 \\
2001 & 1 & 8 & 5 & 5 & 3 & 22 \\
2002 & 1 & 10 & 5 & 4 & 3 & 23 \\
2003 & 1 & 7 & 4 & 3 & 2 & 17
\end{tabular}

a In this table the Lecturer level A, B, C, D and E classifications adopted in the 1990s are used. They refer, respectively, to the positions known traditionally as Senior Tutor, Lecturer, Senior Lecturer, Reader/Associate Professor and Professor. Tutors are not shown as most have been employed part-time and many only for short periods. 
Table 4: Titled, Emeritus and Adjunct Professors, 1959-2003

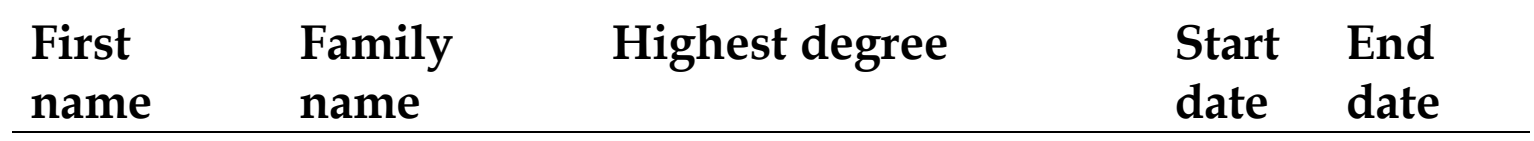

George Gollin Chair of Economics

$\begin{array}{lllll}\text { Peter } & \text { Karmel } & \text { Ph.D. (Cambridge) } & 1959 & 1961 \\ \text { Harold } & \text { Lydall } & \text { M.A. (Oxford) } & 1962 & 1967 \\ \text { Frank } & \text { Jarrett } & \text { Ph.D. (Iowa) } & 1968 & 1988 \\ \text { Jonathan } & \text { Pincus } & \text { Ph.D. (Stanford) } & 1991 & 2003\end{array}$

Personal Chair in Economics

Geoffrey Harcourt $\quad$ Ph.D. (Cambridge) $1967 \quad 1985$ Kym Anderson Ph.D. (Stanford) 1991

\section{Emeritus Professors}

$\begin{array}{llll}\text { Peter } & \text { Karmel } & \text { Ph.D. (Cambridge) } & 1965 \\ \text { Geoffrey } & \text { Harcourt } & \text { Ph.D. Litt.D. (Cambridge) } & 1988 \\ \text { Keith } & \text { Hancock } & \text { Ph.D. (London) } & 1990 \\ \text { Frank } & \text { Jarrett } & \text { Ph.D. (Iowa) } & 1990 \\ \text { Hugh } & \text { Stretton } & \text { Hon LL.D. (Monash) } & 1990 \\ \text { Cliff } & \text { Walsh } & \text { M.Sc. (Ec.) (London) } & 2001\end{array}$

\section{Adjunct Professors}

$\begin{array}{llll}\text { John } & \text { Siegfried } & \text { Ph.D. (Wisconsin) } & 1987 \\ \text { Joe } & \text { Francois } & \text { Ph.D. (Maryland) } & 1997 \\ \text { Perry } & \text { Shapiro } & \text { Ph.D. (UC Berkeley) } & 1999 \\ \text { Keith } & \text { Maskus } & \text { Ph.D. (Michigan) } & 2000 \\ \text { Max } & \text { Corden } & \text { Ph.D. (LSE) } & 2001 \\ \text { Mike } & \text { Moore } & \text { Formerly New Zealand } & 2001 \\ & & \text { Prime Minister and WTO } \\ & & \text { Director General } \\ \text { Bob } & \text { Nobay } & \text { Ph.D. (Southampton) } & 2001\end{array}$


Table 5: Lecturers elected Fellows (and Presidents) of the learned academies, 1952-2002

Academy of the Social Sciences in Australia

$\begin{array}{lll}\text { Family name } & \text { First name } & \text { Year elected } \\ \text { Anderson } & \text { Kym } & 1994 \\ \text { Chapman } & \text { Bruce } & 1993 \\ \text { Dillon } & \text { John } & 1975 \\ \text { Findlay } & \text { Christopher } & 2002 \\ \text { Grant } & \text { John } & 1975 \\ \text { Hancock } & \text { Keith } & 1968 \text { (President, 1981-84) } \\ \text { Harcourt } & \text { Geoffrey } & 1971 \\ \text { Jarrett } & \text { Frank } & 1976 \\ \text { Karmel } & \text { Peter } & 1952 \text { (President, 1987-90) } \\ \text { Lewis } & \text { Mervyn } & 1986 \\ \text { Melville } & \text { Leslie } & 1953 \text { (President, 1953-58) } \\ \text { Piggott } & \text { John } & 1992 \\ \text { Pincus } & \text { Jonathan } & 1996 \\ \text { Pomfret } & \text { Richard } & 1998 \\ \text { Powell } & \text { Alan } & 1973 \\ \text { Richards } & \text { Eric } & 1984 \\ \text { Richardson } & \text { Sue } & 1994 \\ \text { Russell } & \text { Eric } & 1973 \\ \text { Wallace } & \text { Robert } & 1978 \\ \text { Williams } & \text { Bruce } & 1968\end{array}$

Academy of the Humanities in Australia

$\begin{array}{lll}\text { Richards } & \text { Eric } & 1986 \\ \text { Sheridan } & \text { Tom } & 1995\end{array}$

\section{British Academy}

Artis Michael 
Table 6: Lecturers who became chaired Professors (and ViceChancellors), by initial level ${ }^{a}$ of appointment at Adelaide, 1901-2002

\begin{tabular}{|c|c|c|c|c|c|c|c|}
\hline \multirow[b]{2}{*}{$\begin{array}{l}\text { Family } \\
\text { name }\end{array}$} & \multirow[b]{2}{*}{$\begin{array}{l}\text { First } \\
\text { name }\end{array}$} & \multirow[b]{2}{*}{$\begin{array}{l}\text { Start } \\
\text { date }\end{array}$} & \multicolumn{5}{|c|}{ Year promoted to level: } \\
\hline & & & $\begin{array}{l}\text { End } \\
\text { date }\end{array}$ & B & $\mathrm{C}$ & D & $\mathbf{E}$ \\
\hline \multicolumn{8}{|c|}{ Lecturer E } \\
\hline Isles* & Keith & 1939 & 1945 & & & & \\
\hline Karmel* $^{*}$ & Peter & 1950 & 1965 & & & & \\
\hline Lydall & Harold & 1962 & 1967 & & & & \\
\hline Melville* & Leslie & 1929 & 1931 & & & & \\
\hline Mitchell* & William & 1894 & 1916 & & & & 1912 \\
\hline Pincus $^{\mathrm{d}}$ & Jonathan & 1991 & & & & & \\
\hline Pomfret ${ }^{d}$ & Richard & 1992 & & & & & \\
\hline Shann* & Edward & 1935 & 1935 & & & & \\
\hline Tew & Brian & 1946 & 1949 & & & & \\
\hline Walshb & Cliff & 1980 & 1987 & & & & \\
\hline \multicolumn{8}{|l|}{ Lecturer C } \\
\hline Dillon & John & 1961 & 1964 & & & 1964 & \\
\hline Russell & Eric & 1952 & 1997 & & & 1958 & 1964 \\
\hline Tyers & Rod & 1987 & 1990 & & & & \\
\hline \multicolumn{8}{|c|}{ Lecturer B } \\
\hline Anderson & Kym & 1984 & & & 1986 & & 1991 \\
\hline Artis $^{\mathrm{d}}$ & Michael & 1964 & 1965 & & & & \\
\hline Barton & Allan & 1959 & 1962 & & & & \\
\hline Brunt & Maureen & 1960 & 1964 & & 1963 & & \\
\hline Byron $^{d}$ & Raymond & 1966 & 1966 & & & & \\
\hline Chapman & Bruce & 1981 & 1986 & & 1985 & & \\
\hline Davis & Kevin & 1974 & 1986 & & 1980 & & \\
\hline Findlay & Christopher & 1984 & 1999 & & 1986 & 1992 & \\
\hline Gaston & Noel & 1995 & 1998 & & & & \\
\hline Grant & John & 1951 & 1959 & & & 1957 & \\
\hline Hancock* & Keith & 1959 & 1965 & & & & \\
\hline Harcourt ${ }^{\mathrm{d}}$ & Geoffrey & 1958 & 1985 & & 1963 & 1965 & 1967 \\
\hline Heaton $^{\mathrm{d}}$ & Herbert & 1917 & 1925 & & & & \\
\hline Jarrett & Frank & 1953 & 1988 & & 1956 & 1960 & 1968 \\
\hline LaNauze & John & 1935 & 1939 & & & & \\
\hline Lewis & Mervyn & 1965 & 1987 & 1967 & 1973 & 1980 & \\
\hline Lindner & Robert & 1971 & 1986 & & 1974 & 1981 & \\
\hline McTaggart & Douglas & 1987 & 1987 & & & & \\
\hline
\end{tabular}


Table 6 (continued)

\begin{tabular}{|c|c|c|c|c|c|c|}
\hline $\begin{array}{l}\text { Family } \\
\text { name }\end{array}$ & $\begin{array}{l}\text { First } \\
\text { name }\end{array}$ & $\begin{array}{l}\text { Start } \\
\text { date }\end{array}$ & $\begin{array}{l}\text { End } \\
\text { date }\end{array}$ & B & $\mathrm{C}$ & D \\
\hline Mules & Trevor & 1974 & 1993 & 1974 & 1979 & \\
\hline Nguyen & Tom & 1987 & 1989 & & & \\
\hline Piggott & John & 1979 & 1980 & & & \\
\hline Powelld & Alan & 1962 & 1964 & & & \\
\hline Richards & Eric & 1964 & 1967 & & & \\
\hline Richardsonc & Sue & 1974 & & & 1980 & 1992 \\
\hline Round & David & 1971 & 2001 & & 1976 & 1981 \\
\hline Whitehead & Donald & 1958 & 1965 & & & 1964 \\
\hline Williams* & Bruce & 1940 & 1946 & 1946 & & \\
\hline
\end{tabular}

* Sir William Mitchell was Vice-Chancellor at Adelaide (1916-42), Ed Shann at Western Australia (1921-23), Sir Leslie Melville at ANU (1953-60), Keith Isles at Tasmania (1957-1967), Peter Karmel at Flinders (1966-71) and ANU (1982-87), Sir Bruce Williams at Sydney (1967-81), and Keith Hancock at Flinders (1980-87). Prior to Mitchell, the Reverend Professor William Fletcher (who provided lectures on 'Political Economy' to B.A. students from 1878) was Adelaide's V-C 1883-87. At least one of the Economics Honours graduates (and a Rhodes Scholar) also rose to Vice-Chancellor (Deane Terrell, at ANU 1994-2000). And Ross Milbourne, who was associated with the School of Economics while Deputy Vice-Chancellor (Research) at Adelaide (1997-2000), has been Vice-Chancellor of the University of Technology, Sydney since 2001.

a In this table the Lecturer level B, C, D and E classifications, adopted in the 1990s, refer respectively to the positions known traditionally as Lecturer, Senior Lecturer, Reader/ Associate Professor and Professor.

b Cliff Walsh returned to Adelaide and was Professor of Economic Studies in the South Australian Centre for Economic Studies 1992-2001 (and was SACES Executive Director 1992-98), before becoming an Emeritus Professor in the School of Economics in mid-2001.

c Sue Richardson is on extended leave without pay to take the position of Professor and Director of the National Institute of Labour Studies at the Flinders University of South Australia.

d Listed in Blaug (1999) Who's Who in Economics, 3rd edition. 
Table 7: Alphabetical list of Ph.D. graduates, 1971-2003

\begin{tabular}{llc} 
Family name & Other names & $\begin{array}{c}\text { Year of } \\
\text { graduation }\end{array}$ \\
\hline Barnard & Peter Oliver & 1987 \\
Bloch & Frederick A. & 1973 \\
Burns & Jill Penelope A. & 1984 \\
Cheng & Yuk Shin & 1998 \\
Chunlai & Chen & 1998 \\
Da Costa & Helder & 2001 \\
Dao & Thuy Thi Bich & 2000 \\
Easton & Ernest Wright & 1997 \\
Evans & Michael David & 1996 \\
Fischer & Alastair J. & 1996 \\
Fuller & Donald Edwin & 1984 \\
Giesecke & James & 2001 \\
Hastings & Trevor & 1979 \\
Jaforullah & Mohammad & 1990 \\
Jiang & Bing Jiang & 1995 \\
Juniper & James Archibald & 2002 \\
Kazemian & Mahmood & 1997 \\
Lawriwsky & Michael L. & 1982 \\
Lewis & Mervyn Keith & 1978 \\
Lim & Steven A. Leslie & 1996 \\
Ma & Shiguang & 2000 \\
Macintosh & Malcolm L. & 2001 \\
McLeod & Paul Brendon & 1985 \\
Mules & Trevor John & 1974 \\
Neal & Penelope Nancy & 1996 \\
Neri & Frank & 2001 \\
Oakley & Allen Charles & 1981 \\
Park & Young Il & 1987 \\
Peak & Geoffrey Colin & 2002 \\
Peng & Zhao Yang & 1992 \\
Praetz & Peter David & 1973 \\
Rushdi & Abdul A.A.A. & 1985 \\
Sang & Naiquan & 2003 \\
Sardoni & Claudio & 1983 \\
Shea & (Esther) Yi Ping & 2003 \\
Sheridan & Kyoko &
\end{tabular}


Table 7 (continued)

\begin{tabular}{llc} 
Family name & Other names & $\begin{array}{c}\text { Year of } \\
\text { graduation }\end{array}$ \\
\hline Smith & Peter & 1979 \\
Soonthonsiripong Nittiya & 1999 \\
Strutt & Anna & 1999 \\
Tisato & Peter Michael & 1996 \\
Watson & Alistair Stuart & 1971 \\
Wittwer & Glyn Martin & 2000 \\
Wu & Yanrui & 1994 \\
Zhang & Xiao He & 1994
\end{tabular}


Table 8: Titles of theses of Ph.D. graduates, by year of graduation, 1971-2003

\section{1}

Sheridan, K., Growth of the firm in Australia.

Watson, A.S., An economic and statistical analysis of factors affecting the rate of growth of the Australian sheep population.

\section{3}

Bloch, F.A., Expectations, risk aversion and the term structure of interest rates in Australia.

Praetz, P.D., A statistical study of fluctuations of Australian share prices.

1974

Mules, T.J., Supply analysis for Australian agricultural products with applications to farm and national income estimation.

1978

Lewis, M.K., Time lags and effectiveness of monetary policy in Australia.

1979

Hastings, T., The economics of public sector scientific research in Australian agriculture.

Smith, P., Keynes's finance motive: some theory and evidence.

1981

Oakley, A.C., The evolution and critico-analytical significance of Karl Marx's theory of surplus value prior to Capital.

1982

Lawriwsky, M.L., Managers and markets: internal organisation and external market restraints of Australian company performance. 


\section{Table 8 (continued)}

\section{3}

Sardoni, C., Economic crises and effective demand in Ricardo, Marx and Keynes.

\section{4}

Burns, J.P.A., Experimentation and economic theory.

Fuller, D.E., Methods for estimating the demand for and supply of 1985 labour in urban and regional operational planning models

McLeod, P.B., An analysis of disaggregate models of modal choice based on the journey to work in Sydney.

Rushdi, A.A.A.A., Electricity in South Australia: cost, price and demand, 1930-1980.

1987

Barnard, P.O., Modelling shopping destination choices: a theoretical and empirical investigation.

Park, Y.I., Australia-Korea trade, 1962-1981.

1990

Jaforullah, M., Energy modelling in a general equilibrium framework with alternative production specifications.

1992

Peng, Z.Y., External shocks and structural adjustment in the postreform Chinese economy: the case of the 1986 oil price fall.

1994

$\mathrm{Wu}, \mathrm{Y}$., Productive performance of Chinese enterprises: a stochastic frontier analysis.

Zhang, X.H., Economic liberalisation, dualism and the international trade patterns of China: theory and evidence.

1995

Jiang, B.J., The emergence of a land market in China. 


\section{Table 8 (continued)}

\section{6}

Evans, M.D., Determinants of underpricing for initial public offerings of shares in privatised companies.

Fischer, A.J., How should I vote? A study of various aspects of voting systems used in parliamentary elections, particularly in Australia.

Lim, S.A.L., Inconsistencies in China's socialist development strategies

Neal, P.N., Monetary policy, credit rationing and uncertainty.

Tisato, P.M., User economies of scale and optimal bus subsidy.

\section{7}

Easton, E.W., Rail charges and costs: transport of export coal.

Kazemian, M., Financial deregulation and the monetary transmission mechanism of the Australian economy.

\section{8}

Cheng, Y.S., Regional income distribution in China, 1978-1995.

Chen, C., Foreign direct investment in China: determinants, origins and impacts.

\section{9}

Soonthonsiripong, N., Regulatory reforms of telecommunications in developing countries: a case study of the fixed-line telephone network in Thailand.

Strutt, A., Economic growth, trade policy and the environment in Indonesia.

2000

Dao, T.T.B., A purely theoretical study of economic growth on small open economies.

Ma, S., Tests of informational efficiency of China's stock markets.

Wittwer, G. M., Australian wine industry during a period of boom and tax changes. 
Table 8 (continued)

2001

Da Costa, H., Building East Timor's economy: roles of foreign aid, trade and investment.

Giesecke, J., FEDERAL-F: a multi-regional multi-sectoral dynamic model of the Australian economy.

Macintosh, M.L., The management of change in four manufacturing industries.

Neri, F., Schooling quality and economic growth.

2002

Juniper, J., A Keynesian critique of recent finance and macroeconomic applications of risk-sensitive and robust control theory.

Peak, G.C., Product Innovation and Differentiation, Intra-Industry Trade and Growth.

2003

Sang, N., Vertinal Coordination in the Chinese Agri-Food System: A Transaction Cost Approach.

Shea, Y.P. (Esther), The Political Economy of China's Grain Policy Reform. 
Table 9: Alphabetical list of Masters graduates, 1950-2002

\begin{tabular}{|c|c|c|c|}
\hline Family name & First name & Other name & Date \\
\hline Alauddin & Mohammad & & 1982 \\
\hline Anderson & Kym & & 1975 \\
\hline Arnold & Anne & Jillian & 1984 \\
\hline Artati & Rahmi & & 2000 \\
\hline Bailey & Alan & Paterson & 1952 \\
\hline Ball ${ }^{b}$ & Jeffrey & William & 1974 \\
\hline Beetham & Richard & Matthew & 1967 \\
\hline Berger & Nicholas & James & 2001 \\
\hline Boehm & Ernst & Arthur & 1955 \\
\hline Butterfield ${ }^{b}$ & Martin & Alec & 1980 \\
\hline Cameron & Roy & James & 1951 \\
\hline Chataway & John & Graham & 1976 \\
\hline Das & Harendra & Nath & 1982 \\
\hline Daviesa & Mel & & 1978 \\
\hline Daweb & Michele & Mary & 1968 \\
\hline Dent & Warren & Thomas & 1967 \\
\hline Dickson & Ian & & 1998 \\
\hline Duldig & Paul & Jonathon M. & 1997 \\
\hline Ecker & Florian & Josef & 1977 \\
\hline Edgar & Robert & John & 1972 \\
\hline Emeny & Matthew & & 1998 \\
\hline Gilbert $^{a}$ & Ronald & Sunther & 1959 \\
\hline Goodwin & Jennifer & Dorothy & 1986 \\
\hline Grant & John & McBain & 1953 \\
\hline Griggs & Robert & Leslie & 1955 \\
\hline Gynther & Reginald & Sydney & 1964 \\
\hline Hancock & Katherine & & 1999 \\
\hline Hansen & Brian & Robert & 1981 \\
\hline Hastings & Trevor & Robert & 1975 \\
\hline Hefford & Ronald & Keith & 1962 \\
\hline Henderson & Murray & Scott & 1966 \\
\hline Hill & Malcolm & Robert & 1957 \\
\hline Hirst & Ronald & Robert & 1950 \\
\hline Hodan & Miroslav & & 1956 \\
\hline Hodgkinson & Ann & Thelma & 1983 \\
\hline Horrocks & Jack & & 1976 \\
\hline Hunt ${ }^{b}$ & Benjamin & Francis & 1975 \\
\hline James & Sallie & Griffin & 2000 \\
\hline Kalijaran & Kaleeswaran & & 1998 \\
\hline Kenyon & Peter & Damian & 1983 \\
\hline
\end{tabular}


Table 9 (continued)

\begin{tabular}{|c|c|c|c|}
\hline Family name & First name & Other name & Date \\
\hline Kerin & Paul & Domenic & 1986 \\
\hline Kerr & Prudence & & 1979 \\
\hline Kolf & Klaus & Peter & 1987 \\
\hline Lawson & Emma & Kate & 1998 \\
\hline Lim & Guay & Cheng & 1978 \\
\hline Lindnerb & Robert & Ken & 1968 \\
\hline Machmud & T. M. Zakir & Sjakur & 2001 \\
\hline Mackay & James & Gordon & 1974 \\
\hline McMurtrie & John & Menzies & 1975 \\
\hline Meng & Xianchuan & & 1992 \\
\hline Moffatt & Graeme & Gilbert & 1960 \\
\hline Mohmaudi & Parvin & & 2001 \\
\hline Molhuysen & Philipp & Christiaan & 1966 \\
\hline Mules & Trevor & John & 1968 \\
\hline Nicolaou & Marios & & 2001 \\
\hline Pardeyb & Philip & Gordon & 1979 \\
\hline Parsons & Stephen & Athol & 1981 \\
\hline Peirson & Clive & Graham & 1964 \\
\hline Penny & David & Harry & 1958 \\
\hline Penrose & John & Michael & 1975 \\
\hline Pflaum & Peter & Theo & 1971 \\
\hline Quang & Thanh & Le & 2002 \\
\hline Rodway & David & Charles & 1974 \\
\hline Rondonuwu & Octavianus & & 1988 \\
\hline Rosser & Bruce & Alexander & 1984 \\
\hline Salek & Abdus & & 1983 \\
\hline Scarman & Ian & Edwin & 1967 \\
\hline Stalley & Douglas & John & 1955 \\
\hline Stanford & Lawrence & John & 1994 \\
\hline Sturmey & Stanley & George & 1954 \\
\hline Suppanachai & Piluntana & & 2000 \\
\hline Taylor & Philip & John & 1994 \\
\hline Thomson & Norman & John & 1973 \\
\hline Tisato & Peter & Michael & 1991 \\
\hline Young & Douglas & Arthur & 1992 \\
\hline Youngb & Michael & Denis & 1981 \\
\hline
\end{tabular}

a Ronald Gilbert and Mel Davies graduated Master of Arts in Economics.

b Jeff Ball, Martin Butterfield, Michele Dawe, Ben Hunt, Robert Lindner, Philip Pardey and Michael Young graduated Master of Agricultural Science (Economics) 
Table 10: Titles of theses of Masters graduates, by year of graduation, 1950-2002

1950

Hirst, R.R., Aspects of the development of secondary industry in South Australia in recent years.

1951

Cameron, R.J., Standard hours and the basic wage: an analysis of two aspects of the work of the Commonwealth Court of Conciliation and Arbitration.

1952

Bailey, A.P., Survey of economic conditions in two pastoral areas of South Australia, with particular reference to the provision of credit.

1953

Grant, J.McB., Life assurance in Australia and its economic consequences.

1954

Sturmey, S.G., Economic implications of betting in South Australia.

1955

Boehm, E.A., Economic development of electricity supply in South Australia.

Griggs, R.L., An analysis of the United States demand for Australian exports.

Stalley, D.J., Some aspects of pricing theory: a theoretical and statistical investigation of gross profit margins with reference to Queensland's secondary industry.

1956

Hodan, M., Economic analysis of Australian agricultural marketing.

1957

Hill, M.R., Housing finance in Australia. 


\section{Table 10 (continued)}

\section{8}

Penny, D.H., The role of the government in the economic development of South East of South Australia.

1959

aGilbert, R.S., Australian Loan Council, 1923-1929.

1960

Moffatt, G.G., The effects of the Japanese-Australian Trade Agreement on the Australian economy.

1962

Hefford, R.K., An investigation into the need for and use of rural credit in selected areas in South Australia.

\section{4}

Gynther, R.S., Accountancy and changing price levels.

Peirson, C.G., The structure and financing of Australian public capital formation, 1956-57 to 1959-60.

\section{6}

Henderson, M.S., Sources of fluctuations in outstanding advances of the major Australian trading banks.

Molhuysen, P.C., The supply of scientific skill in Australia.

\section{7}

Dent, W.T., Optimal wool flows and the location of new woolselling centres in Australia.

Scarman, I.E., The financial problems of small firms in Australia.

\section{8}

${ }^{b}$ Dawe, M.M., An investigation into factors affecting changes in wool quantity and quality number in South Australia.

bLindner, R.K., A sources and uses of funds study on South Australian farms.

Mules, T.J., Inter-industry analysis and the South Australian wool industry. 


\section{Table 10 (continued)}

1971

Pflaum, P.T., A study in the family income distribution and redistribution, Australia.

1972

Edgar, R.J., The Australian pastoral houses: an industry study.

1973

Thomson, N.J., The incidence and effects of death duties on wool growers in South Australia.

1974

bBall, J.W., The economics of winter-spring versus autumn shearing. McKay, J.G., Methods of financing the Australian health services. Rodway, D.C., Characteristics of administrators: a study of administrators in the South Australian public service.

1975

Anderson, K., An econometric study of supply responses in the Australian barley industry.

Hastings, T.R., The diffusion of new technology in the Australian wool textile industry.

bHunt, B.F., An empirical study of price formation on the Sydney wool futures market.

McMurtrie, J.M., Investment criteria in agriculture with reference to the Northern Territory beef-industry.

Penrose, J.M., Investment in human capital by education in South Australia, 1910-1968.

1976

Chataway, J.G., Banking and economic development: the role of the Bank of Adelaide in South Australia, 1865-1915.

Horrocks, J., Principles of disclosure for companies in Australia.

1977

Ecker, F.J., The use of stochastic processes in the study of Australian exports. 


\section{Table 10 (continued)}

\section{8}

aDavies, M., The South Australian Mining Association and the marketing of copper and copper ores, 1845-1877.

\section{9}

Kerr, P., A review of the Cambridge school.

bPardey, P.G., The diffusion of trace element technology: an economic analysis.

\section{0}

bButterfield, M.A., Regional input-output tables: a South Australian investigation.

\section{1}

Hansen, B.R., Supply response in the grain sector of South Australia: the impact of wheat delivery quotas on wheat and barley plantings in South Australia.

Parsons, S.A., The livestock auction: an economic reappraisal.

Young, M.D., A socio-economic analysis of Australian arid land administration, with special reference to western New South Wales.

1982

Alauddin, M., Choice of technology in Bangladesh agriculture: an R\&D perspective.

Das, H.N., Planning for power generation in the southern region of India.

1983

Hodgkinson, A.T., The regional problem in South Australia.

Kenyon, P.D., Some aspects of pricing and the investment decision in post-Keynesian economics.

Salek, A., An econometric model of Bangladesh, 1949/50-1977/78.

\section{4}

Arnold, A.J., An economic analysis of wheat variety research and development in South Australia, 1857-1975.

Rosser, B.A., Economies of scale in Australian life insurance. 


\section{Table 10 (continued)}

\section{6}

Goodwin, J.D., The valuation and accounting of goodwill arising on consolidation: a survey of companies making corporate acquisitions during the period 1980-1983.

Kerin, P.D., A spatial economic analysis of the Eyre Peninsula grain handling and transportation system.

1987

Kolf, K.P., Pricing optimality of a multi-product public enterprise.

1988

Rondonuwu, O., An economic analysis of coconut intercropping on smallholder farms in Minahasa district in Indonesia: a mathematical programming approach.

1991

Tisato, P.M., An improved bus user model and its impact on subsidy.

1992

Meng, X., Production structure of Shenzhen SEZ.

Young, D.A., Restrictions on the trade of biological resources: the case of Australian merino genes.

1994

Stanford, L.J., The Queensland raw sugar industry: government regulation and assistance.

Taylor, P.J., Australian horticultural exports: an economic analysis of the potential for growth.

1997

Duldig, P.J.M., The dynamics of intra-state aviation competition in South Australia. 


\section{Table 10 (continued)}

\section{8}

Dickson, I., Institutions affecting integration between Chinese and international steel prices.

Emeny, M., The book-to-market effect and the behaviour of stock returns in the Australian equity market.

Kalijaran, K., Estimating the gravity equation using the stochastic frontier approach.

Lawson, E.K., Determinants of Japanese and United States direct foreign investment and the effect of differences in the DFI determinants on Australian investment facilitation programs.

1999

Hancock, K., Forest use by Indonesia's poor: modelling harvest and conversion decisions.

2000

Artarti, R., Measuring the independence of the central bank: the case of Indonesia.

James, S.G., An economic analysis of quarantine and food safety issues following the SPS Agreement.

Suppanachai, P., The Thai economy in the wake of agricultural liberalization and the 1997 economic crisis: the case of rice.

2001

Berger, N.J., Modelling structural and policy changes in the world wine market into the $21^{\text {st }}$ century.

Machmud, T.M.Z.S., Mark up pricing: evidence from Indonesian manufacturing.

Mohmaudi, P., Cross hedging of currency risk under stochastic interest rates: futures versus forwards.

Nicolaou, M., The Australian olive industry: an analysis of prospects for profitable expansion.

2002

Quang, T.L., Study effort, social security and economic growth.

a Gilbert and Davies graduated Master of Arts in Economics

b Ball, Butterfield, Dawe, Hunt, Lindner, Pardey and Young graduated Master of Agricultural Science (Economics) 
Table 11: Alphabetical list of Honours graduates, 1945-2002

\begin{tabular}{|c|c|c|c|c|c|}
\hline Family name & First name & Other name & & $\begin{array}{l}\text { Year of } \\
\text { graduation }\end{array}$ & $\begin{array}{c}\text { Year } \\
\text { mmenced }\end{array}$ \\
\hline Abraham & Darryn & Ross & & 1984 & 1983 \\
\hline Alexander & Michael & John & & 1988 & 1987 \\
\hline Allen & Kenneth & Craig & & 1962 & 1961 \\
\hline Allen & Creina & Louise & & 1996 & 1992 \\
\hline Amstad & Ian & Crawford & & 1985 & 1984 \\
\hline Andary & Jeffery & Dean & & 1976 & 1975 \\
\hline Andersen & Michael & David & & 1986 & 1985 \\
\hline Anderson & Jane & Louise & & 1997 & 1996 \\
\hline Angove & Margaret & Rosemary & & 1977 & 1976 \\
\hline Appleby & Simon & Louis & & 1994 & 1993 \\
\hline Archer & Brett & Allan & & 1984 & 1983 \\
\hline Arnold & Anne & Jillian & * & 1975 & 1974 \\
\hline Ashcroft & John & & & 1957 & 1956 \\
\hline Aungles & Phillip & Bage & & 1980 & 1979 \\
\hline Bailey & Alan & Paterson & & 1948 & \\
\hline Bailey & Grant & Andrew & & 1974 & 1973 \\
\hline Baker & William & Richard & & 1973 & 1972 \\
\hline Baker & Meredith & Anne & & 1985 & 1984 \\
\hline Balchin & Jeffrey & John & * & 1992 & 1991 \\
\hline Bald & Andrew & John & & 1985 & 1984 \\
\hline Bannister & Geoffrey & Colin & & 1985 & 1984 \\
\hline Bansemer & Penelope & Gail & & 1980 & 1979 \\
\hline Barber & Randy & C. & & 1975 & 1974 \\
\hline Barrett & Susan & Meredith & & 1972 & 1971 \\
\hline Bartholomew & David & James & & 1982 & 1981 \\
\hline Barton & Julienne & & * & 1977 & 1976 \\
\hline Bassanese & David & John & * & 1987 & 1986 \\
\hline Bastian & Bruce & Robert & & 2002 & 2002 \\
\hline Bastin & Lyle & Damien & & 1985 & 1984 \\
\hline Bee & John & Broadhurst & & 1965 & 1964 \\
\hline Belchamber & Grant & & * & 1980 & 1979 \\
\hline Benger & Brian & Garfield & & 1971 & 1970 \\
\hline Berger & Nicholas & & & 1998 & 1997 \\
\hline Best & Simon & Peter & $\#^{*}$ & 1973 & 1972 \\
\hline Bigg & Steven & Alan & & 1982 & 1981 \\
\hline Bishop & Matthew & Paul & & 1998 & 1997 \\
\hline Bitter & Susan & & & 1978 & 1977 \\
\hline
\end{tabular}


Table 11 (continued)

\begin{tabular}{|c|c|c|c|c|c|}
\hline Family name & First name & Other name & & $\begin{array}{c}\text { Year of } \\
\text { graduation }\end{array}$ & $\begin{array}{l}\text { Year } \\
\text { mmenced }\end{array}$ \\
\hline$\overline{\text { Blandy }}$ & Richard & John & * & 1962 & 1961 \\
\hline Blias & Athena & & & 2000 & 1999 \\
\hline Bloch & Frederick & Archibald & * & 1968 & 1967 \\
\hline Boehm & Ernst & Arthur & * & 1950 & \\
\hline Bowes & Christian & & & 1999 & 1998 \\
\hline Bowley & Christopher & James & & 1994 & 1993 \\
\hline Boxall & Craig & & & 1977 & 1976 \\
\hline Branch & Stephen & Richard & & 1974 & 1973 \\
\hline Bratkovic & Lydia & & $\wedge$ & 2000 & 1999 \\
\hline Britten-Jones & Mark & & & 1988 & 1987 \\
\hline Brooks & Angus & John & $\wedge$ & 2002 & 2002 \\
\hline Brownbill & Mark & Gregory & & 1978 & 1977 \\
\hline Brummitt & William & & & 1990 & 1989 \\
\hline Bruten & Guy & & & 1990 & 1989 \\
\hline Bulbeck & Margaret & Cachilla & & 1973 & 1972 \\
\hline Bull & Malcolm & Charles & & 1984 & 1983 \\
\hline Burgan & Barry & & * & 1978 & 1977 \\
\hline Butler & David & John & & 1977 & 1976 \\
\hline Butler & Mark & & & 1984 & 1983 \\
\hline Byrne & Jeffery & Lee & * & 1974 & 1973 \\
\hline Caddick & Oliver & James & & 1986 & 1985 \\
\hline Cameron & Roy & James & * & 1949 & \\
\hline Campi & Todd & & & 1990 & 1989 \\
\hline Cannavo & Salvatore & John Paul & & 1977 & 1976 \\
\hline Cardak & Buly & Ahmet & * & 1992 & 1991 \\
\hline Carter & Stephen & Douglas & & 1991 & 1990 \\
\hline Caruso & Daniel & & & 2000 & 2000 \\
\hline Caton & Christopher & Nigel & \#* & 1967 & 1966 \\
\hline Chalmers & Michael & John & & 1991 & 1990 \\
\hline Chan & Pooi & Hoong & * & 1973 & 1972 \\
\hline Chapman & Paul & Noel & & 1979 & 1978 \\
\hline Chapman & Lisa & & & 1997 & 1996 \\
\hline Cheok & Albert & Say Chuan & * & 1976 & 1975 \\
\hline Chia & Tai & Tee & * & 1986 & 1985 \\
\hline Chiang & Yao & Chye & * & 1989 & 1988 \\
\hline Chua & Wee-Meng & Cameron & * & 1967 & 1966 \\
\hline
\end{tabular}


Table 11 (continued)

\begin{tabular}{|c|c|c|c|c|c|}
\hline Family name & First name & Other name & & $\begin{array}{c}\text { Year of } \\
\text { graduation }\end{array}$ & $\begin{array}{l}\text { Year } \\
\text { mmenced }\end{array}$ \\
\hline$\overline{\text { Chua }}$ & Kian & Hwa & & 1986 & 1985 \\
\hline Clarke & Patrick & & & 1995 & 1994 \\
\hline Coat & Jillian & Irene & & 1958 & 1957 \\
\hline Cockburn & Malcolm & & & 1958 & 1957 \\
\hline Codd & Michael & Henry & & 1962 & 1961 \\
\hline Coffey & Philip & Matthew & & 1979 & 1978 \\
\hline Coghlan & Julian & Francis & & 1986 & 1985 \\
\hline Coker & Colin & John & & 1982 & 1981 \\
\hline Comber & Richard & & & 1974 & 1973 \\
\hline Cook & Peter & Sydney & & 1964 & 1961 \\
\hline Cooper & Anne & Maree & & 1984 & 1983 \\
\hline Cormie & Bernard & John & & 1984 & 1983 \\
\hline Cornelius & Gary & Lance & * & 1971 & 1970 \\
\hline Cowan & Peter & Clifford & & 1975 & 1974 \\
\hline Craig & David & & & 1985 & 1984 \\
\hline Crisci & Paul & & & 1998 & 1997 \\
\hline Crosby & Mark & & & 1986 & 1985 \\
\hline Croser & Johanna & & * & 2000 & 2000 \\
\hline Crowle & Cedric & Thomas & & 1984 & 1982 \\
\hline Cully & Mark & Robert & & 1988 & 1987 \\
\hline Dahlberg & Dane & Louis & & 1964 & 1963 \\
\hline Danaro & Giovanni & & & 1972 & 1971 \\
\hline Dare & Anthea & Jane & & 1996 & 1995 \\
\hline Davey & Oliver & Leopold & & 1988 & 1987 \\
\hline Davis & Robert & William & & 1963 & 1962 \\
\hline Davis & Bronwyn & & & 2000 & 1999 \\
\hline Day & Garth & & & 1999 & 1998 \\
\hline De Blasio & Leo & D. & & 2000 & 1999 \\
\hline De Picot & Andrew & Scott & & 1984 & 1983 \\
\hline De Roos & Nicolas & & * & 1994 & 1993 \\
\hline Debelle & Guy & Lawrence & & 1988 & 1987 \\
\hline Della-Torre & Kym & & & 1993 & 1992 \\
\hline Denton & Stephanie & & & 1978 & 1977 \\
\hline Doherty & Laura & Nadine & & 2002 & 2002 \\
\hline Dolman & Benjamin & & * & 2000 & 1999 \\
\hline Donnelly & Roger & Norman & & 1978 & 1977 \\
\hline
\end{tabular}


Table 11 (continued)

\begin{tabular}{|c|c|c|c|c|c|}
\hline Family name & First name & Other name & & $\begin{array}{c}\text { Year of } \\
\text { graduation }\end{array}$ & $\begin{array}{c}\text { Year } \\
\text { commenced }\end{array}$ \\
\hline$\overline{\text { Dudzinski }}$ & Miroslaw & Leonard & & 1955 & \\
\hline Duerrwald & Karin & Ilse & & 1998 & 1997 \\
\hline Dugain & Valery & Pascal & & 2000 & 2000 \\
\hline Duldig & Paul & & & 1986 & 1985 \\
\hline Dunstan & Gretel & & \# & 1962 & 1961 \\
\hline Easton & Stephen & Andrew & & 1983 & 1982 \\
\hline Eckermann & Lee & David & & 1969 & 1968 \\
\hline Eckermann & Simon & Douglas & & 1992 & 1991 \\
\hline Edgar & Robert & John & & 1969 & 1968 \\
\hline Edwards & Richard & Graham & & 1967 & 1966 \\
\hline Edwards & Christopher & Timothy & & 1986 & 1985 \\
\hline Ellis & William & & & & 2001 \\
\hline Emeny & Matthew & & & 1997 & 1996 \\
\hline Emery & Peter & John & \# & 1967 & 1966 \\
\hline Emery & David & & & 1997 & 1996 \\
\hline Evans & David & Wyke & * & 1957 & 1956 \\
\hline Evans & William & David & * & 1975 & 1974 \\
\hline Evans & Scott & Francis & * & 1984 & 1983 \\
\hline Evens & Susan & Margaret & * & 1978 & 1977 \\
\hline Fairbairn & David & Francis & & 1966 & 1965 \\
\hline Fedorowicz & Tadeusz & Kazimierz & & 1979 & 1978 \\
\hline Feijen & Nicole & & & 1997 & 1996 \\
\hline Findlay & Christopher & Charles & & 1975 & 1974 \\
\hline Findlay & Narelle & Megan & & 1994 & 1993 \\
\hline Flavel & Matthew & James & & 1994 & 1993 \\
\hline Flew & Robert & John & & 1964 & 1963 \\
\hline Fong & Yeng & Fatt & & 1986 & 1985 \\
\hline Forbes & Angus & & & 1988 & 1986 \\
\hline Fowdur & Lona & & * & 2002 & 2002 \\
\hline Fowler & Robert & Malcolm & & 1958 & 1957 \\
\hline Francis & Michael & Murray & & 1984 & 1982 \\
\hline Fraser & Robert & Weston & * & 1977 & 1976 \\
\hline Freak & Brian & & & 2000 & 2000 \\
\hline Freney & Roger & Quentin & & 1966 & 1965 \\
\hline Fuller & Donald & Edwin & * & 1972 & 1971 \\
\hline Gan & Hean & Bee & & 1970 & 1969 \\
\hline
\end{tabular}


Table 11 (continued)

\begin{tabular}{|c|c|c|c|c|c|}
\hline Family name & First name & Other name & & $\begin{array}{c}\text { Year of } \\
\text { graduation }\end{array}$ & $\begin{array}{c}\text { Year } \\
\text { ommenced }\end{array}$ \\
\hline Gascoine & Digby & Frank & & 1967 & 1966 \\
\hline Gaston & Noel & George & & 1977 & 1976 \\
\hline Gaudry & Brendan & Paul & & 1987 & 1986 \\
\hline Georgiou & Vassilis & & & 1976 & 1975 \\
\hline Gerhardy & Peter & Graham & * & 1986 & 1985 \\
\hline Gibbard & Peter & John & * & 1990 & 1989 \\
\hline Gibbs & Graham & Rossiter & & 1953 & \\
\hline Gibbs & Ian & & & 1978 & 1977 \\
\hline Giesecke & James & Andrew & * & 1992 & 1991 \\
\hline Gilbert & Ronald & Sunter & \# & 1950 & \\
\hline Giles & Simon & William & & 2002 & 2002 \\
\hline Gladigau & Shane & & & 1998 & 1997 \\
\hline Gobbett & Darryl & John & & 1976 & 1975 \\
\hline Goldsworthy & Brenton & Keith & * & 1998 & 1997 \\
\hline Gordon & Wayne & Robert & & 2002 & 2002 \\
\hline Gosnold & Paul & & & 1997 & 1996 \\
\hline Goward & Prudence & Jane & \# & 1976 & 1975 \\
\hline Grant & John & McBain & * & 1950 & \\
\hline Gray & Matthew & & * & 1996 & 1995 \\
\hline Graziani & Robert & & & 1996 & 1995 \\
\hline Grbin & David & & & 1986 & 1985 \\
\hline Grdosic & Mike & & & 1995 & 1994 \\
\hline Griffiths & Peter & Royston & & 1963 & 1962 \\
\hline Griggs & Robert & Leslie & * & 1953 & 1952 \\
\hline Haddy & Brian & Robert & & 1976 & 1975 \\
\hline Hahn & Peter & & & & 1996 \\
\hline Hales & Brian & & & 1991 & 1988 \\
\hline Hall & Anthony & David & * & 1970 & 1969 \\
\hline Hall & Damon & & & 1998 & 1997 \\
\hline Hambley & Graeme & Victor & & 1973 & 1972 \\
\hline Hancock & James & & & 1986 & 1985 \\
\hline Harcourt & Tim & & & 1987 & 1986 \\
\hline Harmstorf & Hugo & Neil & & 1993 & 1992 \\
\hline Harries & Robert & Ian & * & 1965 & 1964 \\
\hline Harrington & Mark & & & & 1995 \\
\hline Harriss & John & Martin & & 1976 & 1975 \\
\hline
\end{tabular}


Table 11 (continued)

\begin{tabular}{|c|c|c|c|c|c|}
\hline Family name & First name & Other name & & $\begin{array}{l}\text { Year of } \\
\text { raduation }\end{array}$ & $\begin{array}{c}\text { Year } \\
\text { ommenced }\end{array}$ \\
\hline Hart & Linda & Catherine & & 1979 & 1978 \\
\hline Harvey & Sallyann & & * & 1999 & 1998 \\
\hline Haslam & William & Ross & & 1968 & 1967 \\
\hline Hastings & Trevor & Robert & * & 1972 & 1971 \\
\hline Head & John & Graeme & * & 1955 & \\
\hline Heddle & Gervaise & Robert & * & 1994 & 1993 \\
\hline Hefford & Christine & Barbara & $\#^{*}$ & 1977 & 1976 \\
\hline Heinrich & Harold & Gordon & * & 1957 & 1956 \\
\hline Hempton & John & Ick & & 1991 & 1990 \\
\hline Henderson & James & Young & * & 1962 & 1961 \\
\hline Henderson & Murray & Scott & & 1963 & 1961 \\
\hline Henning & Graydon & Read & $\# !$ & 1964 & 1963 \\
\hline Herbert & Marianne & & & 2000 & 1999 \\
\hline Hester & Samuel & Thomas & & 1998 & 1997 \\
\hline Heywood & Troy & & & 1998 & 1997 \\
\hline Hicks & Ronald & Pettinger & & 1961 & 1960 \\
\hline Hieser & Ronald & Oswald & * & 1949 & \\
\hline Hill & Malcolm & Robert & * & 1952 & \\
\hline Hillier & Grant & Highmoore & * & 1968 & 1967 \\
\hline Hirst & Ronald & Robert & * & 1948 & \\
\hline Hirst & Jane & Adah & & 1969 & 1968 \\
\hline Hodan & Miroslav & & & 1954 & 1953 \\
\hline Hodder & Michael & William & & 1976 & 1975 \\
\hline Holdich & Thomas & & & 1993 & 1992 \\
\hline Hollow & Bronte & David & & 1985 & 1984 \\
\hline Holthuyzen & Michael & Rudolf & & 1975 & 1972 \\
\hline Howard & Donald & William D. & & 1949 & \\
\hline Howarth & Penelope & & & 1994 & 1993 \\
\hline Howarth & Nicholas & & & 1998 & 1997 \\
\hline Hubbard & David & John & & 1977 & 1976 \\
\hline Hudson & David & Hugh & & 1984 & 1983 \\
\hline Hutchins & David & Allan & & 1993 & 1992 \\
\hline Inverarity & Stephen & Frank & & 1975 & 1974 \\
\hline Ivanbrook & Casimir & Luke & * & 1987 & 1986 \\
\hline Jackson & Melinda & Ann & & 1992 & 1991 \\
\hline Jacobi & Chad & & * & 2000 & 2000 \\
\hline
\end{tabular}


Table 11 (continued)

\begin{tabular}{|c|c|c|c|c|c|}
\hline Family name & First name & Other name & & $\begin{array}{c}\text { Year of } \\
\text { graduation }\end{array}$ & $\begin{array}{c}\text { Year } \\
\text { commenced }\end{array}$ \\
\hline James & Sallie & & & & 1997 \\
\hline Jenkins & Anna & Saies & & 2001 & 2001 \\
\hline John & Carsten & Mark & & 1994 & 1993 \\
\hline Johns & Jennifer & & & 1982 & 1981 \\
\hline Johnson & Graham & Neal & * & 1976 & 1975 \\
\hline Johnson & Colin & William & & 1987 & 1986 \\
\hline Johnson & Brian & & & 2001 & 2001 \\
\hline Jones & Michelle & Louise & & 1990 & 1988 \\
\hline Jordan & Daniel & & * & 1997 & 1996 \\
\hline Juhasz & Ferenc & & & 1958 & 1957 \\
\hline Kahland & Aaron & & & 2001 & 2001 \\
\hline Kain & John & Damian & & 1974 & 1973 \\
\hline Kain & Mark & & & 1998 & 1997 \\
\hline Kalisch & David & Wayne & & 1982 & 1981 \\
\hline Kanjanasupak & Luxana & & & 1998 & 1997 \\
\hline Keda & Sonia & & & 1992 & 1991 \\
\hline Keese & M. & & & 1982 & 1981 \\
\hline Kerin & Paul & & * & 1982 & 1981 \\
\hline Kim & Yeon & & & 1992 & 1990 \\
\hline Kinch & Aisling & Mary & & 1990 & 1988 \\
\hline King & Yasmin & Anna & & 1981 & 1980 \\
\hline Kirkpatrick & Grant & Hain & & 1973 & 1972 \\
\hline Knapman & Bruce & & & 1971 & 1970 \\
\hline Kok & Sarah & S. & * & 2000 & 1999 \\
\hline Konstas & Mark & Demetrius & & 1986 & 1985 \\
\hline Kossen & Marielle & & & 1993 & 1992 \\
\hline Koster & Maxine & & & 1996 & 1995 \\
\hline Kosturjak & Anthony & Mark & * & 1999 & 1998 \\
\hline Kourteff & Michael & & & 1994 & 1992 \\
\hline Krieg & Anthony & Robert & & 1994 & 1993 \\
\hline Kwong & Lucienne & Lai Wah & \# & 1973 & 1972 \\
\hline Lacar & Francisco & & & 1998 & 1997 \\
\hline Lai & Hon & Kuan & * & 1979 & 1978 \\
\hline Laidlaw & Susan & Margaret & & 1976 & 1975 \\
\hline Lamp & Robert & Alan & & & 1986 \\
\hline Lane & Colin & George & & 1976 & 1975 \\
\hline
\end{tabular}


Table 11 (continued)

\begin{tabular}{|c|c|c|c|c|c|}
\hline Family name & First name & Other name & & $\begin{array}{l}\text { Year of } \\
\text { raduation }\end{array}$ & $\begin{array}{l}\text { Year } \\
\text { mmenced }\end{array}$ \\
\hline$\overline{\text { Lau }}$ & Seok & Lee & & 1981 & 1980 \\
\hline Lau & How & Wah & $\wedge$ & 2001 & 2001 \\
\hline Laurencis & Arnold & & & 1984 & 1983 \\
\hline Lawrence & Margaret & Evelyn & \# & 1959 & \\
\hline Lawrie & Graeme & Alan & & 1977 & 1974 \\
\hline Lawriwsky & Michael & Lubomyr & & 1975 & 1974 \\
\hline Lawson & Emma & & & 1997 & 1996 \\
\hline Lawson & Jeremy & & & 2002 & 2000 \\
\hline Layton & Theresa & & & 1993 & 1992 \\
\hline Lean & David & Russell & & 1970 & 1969 \\
\hline Leane & Peter & Alan & & 1964 & 1963 \\
\hline Leane & Geoffrey & William G. & & 1972 & 1971 \\
\hline Lee & Trevor & James & * & 1978 & 1977 \\
\hline Lee & Yuen & Huei & & 1989 & 1988 \\
\hline Leske & John & Raymond & * & 1975 & 1974 \\
\hline Lewis & Robert & Brook & $\#^{*}$ & 1952 & \\
\hline Lewis & Mervyn & Keith & $*$ & 1965 & 1964 \\
\hline Liebelt & Graeme & Richard & & 1975 & 1974 \\
\hline Liew & Voon & Pin & & 1995 & 1994 \\
\hline Lim & Guay & Cheng & * & 1974 & 1973 \\
\hline Lim & Saik & Ghee & & 1975 & 1974 \\
\hline Lim & Soo & Hoon & & 1981 & 1980 \\
\hline Lim & Raymond & Siang & * & 1983 & 1982 \\
\hline Lim & Swee & Huang & * & 1985 & 1984 \\
\hline Lim & Eng & Lee & * & 1986 & 1985 \\
\hline Lim & Geok & Hwee & * & 1986 & 1985 \\
\hline Lim & Paul & & & 1986 & 1985 \\
\hline Lim & Mun Kwok & Jonathan & & 1999 & 1998 \\
\hline Lindsay & Sarah & & & 1997 & 1996 \\
\hline Lithgow & John & Neville & & 1959 & 1958 \\
\hline Lockett & Peter & & & 1981 & 1980 \\
\hline Lum & Foo & Hong & & 1978 & 1977 \\
\hline Lye & Joseph & Victor T. F. & & 1986 & 1985 \\
\hline Lyons-Davis & Andrew & & & 1987 & 1986 \\
\hline Macrow & Michael & Steven & & 1979 & 1977 \\
\hline Maguire & Graham & Ross & & 1970 & 1969 \\
\hline
\end{tabular}


Table 11 (continued)

\begin{tabular}{|c|c|c|c|c|c|}
\hline Family name & First name & Other name & & $\begin{array}{c}\text { Year of } \\
\text { graduation }\end{array}$ & $\begin{array}{l}\text { Year } \\
\text { mmenced }\end{array}$ \\
\hline Maloney & Robert & James & & 1986 & 1985 \\
\hline Mann & Evan & John & * & 1974 & 1973 \\
\hline Markovic & Martin & & & 1975 & 1974 \\
\hline Martin & Geoffrey & Stuart & \# & 1971 & 1970 \\
\hline Martin & Geoffrey & Ian & & 1975 & 1974 \\
\hline Martin & Ryan & Stuart & $\wedge$ & 2000 & 2000 \\
\hline Martyn & Brett & David & & 1994 & 1993 \\
\hline Martyn & Justin & & & 1996 & 1995 \\
\hline Matters & Andrew & & & 1994 & 1993 \\
\hline Matters & Stephanie & Jo & & 1997 & 1996 \\
\hline McArthur & Timothy & & & 2001 & 2001 \\
\hline McCabe & Michael & Desmond & & 1979 & 1978 \\
\hline McCarthy & Paul & & * & 1980 & 1979 \\
\hline McDonald & Stephen & Robert & & 1986 & 1985 \\
\hline McDonald & Patrick & James & & 2002 & 1997 \\
\hline McGuire & Peter & Julian & & 1995 & 1994 \\
\hline McKenna & Donald & Shayne & & 1995 & 1994 \\
\hline McLeod & Paul & Brandon & * & 1973 & 1972 \\
\hline McMurtrie & John & Menzies & & 1970 & 1969 \\
\hline Measday & William & Heddle & & 1990 & 1989 \\
\hline Medwell & John & Gordon & \# & 1955 & 1954 \\
\hline Meier & David & Christopher & & 1990 & 1989 \\
\hline Menadue & John & Laurence & & 1957 & 1956 \\
\hline Miki & Megumi & & & 1994 & 1993 \\
\hline Miller & Benjamin & Lee & * & 1980 & 1979 \\
\hline Milnes & Simon & & & 1996 & 1995 \\
\hline Mitchell & Andrew & & & 2001 & 2001 \\
\hline Mitton & John & & & 1979 & 1978 \\
\hline Moffatt & Graeme & Gilbert & & 1958 & 1957 \\
\hline Molloy & Simon & Francis & & 1981 & 1980 \\
\hline Morissey & Margaret & Jean & & 1986 & 1985 \\
\hline Moyle & Geoffrey & & & 1995 & 1994 \\
\hline Mules & Trevor & John & * & 1966 & 1965 \\
\hline Munchenberg & Robert & & & 1998 & 1996 \\
\hline Myatt & Justin & & * & 1990 & 1989 \\
\hline Need & Melvyn & Brian & & 1977 & 1976 \\
\hline
\end{tabular}


Table 11 (continued)

\begin{tabular}{|c|c|c|c|c|c|}
\hline Family name & First name & Other name & & $\begin{array}{c}\text { Year of } \\
\text { graduation } c\end{array}$ & $\begin{array}{l}\text { Year } \\
\text { mmenced }\end{array}$ \\
\hline$\overline{\text { Nelson }}$ & Stephen & & & 1996 & 1995 \\
\hline $\mathrm{Neo}$ & Yit & Wah & & 1981 & 1980 \\
\hline Newitt & Darryl & Graham & * & 1990 & 1989 \\
\hline Newman & Mark & Edwin & & 1989 & 1988 \\
\hline $\mathrm{Ng}$ & Soo & Nam & * & 1989 & 1988 \\
\hline Nguyen & $\mathrm{Ha}$ & Minh & & 2002 & 2002 \\
\hline Nicholls & Madeleine & & & 1989 & 1988 \\
\hline Nicolle & Timothy & & * & 2001 & 2000 \\
\hline Norman & David & & * & 2001 & 2001 \\
\hline Nukic & Senada & & & 2000 & 2000 \\
\hline O'Brien & Kevin & Patrick & & 1969 & 1968 \\
\hline O’Dea & Daniel & Clarke & & 1984 & 1983 \\
\hline O'Donohue & Raymond & Francis & & 1951 & \\
\hline O'Loughlin & Laurene & Marie & & 1980 & 1979 \\
\hline O'Rourke & Daniel & & & 2001 & 2001 \\
\hline Oakley & Allen & Charles & * & 1973 & 1972 \\
\hline Officer & Stephen & John & * & 1971 & 1970 \\
\hline Olekalns & Nilss & & & 1982 & 1981 \\
\hline Omar & Leah & & & 1989 & 1988 \\
\hline Ong & Boon-Kwee & Peter & * & 1985 & 1984 \\
\hline Opie & Roger & Gilbert & $\#^{*}$ & 1949 & \\
\hline Ordon & Alexander & & & 1996 & 1995 \\
\hline Orr & Douglas & & & 1993 & 1991 \\
\hline Osmond & Robert & Grant & & 1999 & 1998 \\
\hline Palmer & Vivienne & & & 1980 & 1979 \\
\hline Papadopoulos & Chrysanthi & & & 1972 & 1971 \\
\hline Parham & Dean & John & & 1975 & 1974 \\
\hline Parker & David & John & & 1985 & 1983 \\
\hline Parkinson & Martin & & * & 1981 & 1980 \\
\hline Partington & Stephen & John & & 1972 & 1971 \\
\hline Pascoe & Malcolm & Stuart & * & 1971 & 1970 \\
\hline Paterson & Robert & Page & * & 1973 & 1972 \\
\hline Peak & Geoffrey & & & 1993 & 1992 \\
\hline Pearce & Denys & Kingsley & & 1976 & 1975 \\
\hline Pedler & Mark & & & 1999 & 1998 \\
\hline Peirson & Clive & Graham & & 1961 & 1960 \\
\hline
\end{tabular}


Table 11 (continued)

\begin{tabular}{|c|c|c|c|c|c|}
\hline Family name & First name & Othername & & $\begin{array}{c}\text { Year of } \\
\text { graduation }\end{array}$ & $\begin{array}{l}\text { Year } \\
\text { mmenced }\end{array}$ \\
\hline Penketh & Stewart & George & & 1968 & 1967 \\
\hline Penny & David & Harry & * & 1952 & \\
\hline Pentelow & David & Berry & & 1975 & 1974 \\
\hline Petrus & Nathan & & & 1998 & 1997 \\
\hline Pflaum & Peter & Theo & & 1964 & 1963 \\
\hline Philipson & Michael & George & & 1981 & 1980 \\
\hline Phipps & Sarah & Louise & & 1993 & 1992 \\
\hline Phong & Thai & Hoang Ngo & & 2002 & 2002 \\
\hline Phua & Kok & Kim & & 1986 & 1985 \\
\hline Pincombe & Aubyn & Mary & & 2002 & 2002 \\
\hline Piovesan & Franco & & & 1979 & 1978 \\
\hline Piper & Derek & & $\wedge$ & 2000 & 1999 \\
\hline Plews & John & Nicholas & * & 1970 & 1969 \\
\hline Pobke & Clinton & Phillip & & 2002 & 2002 \\
\hline Pocock & Barbara & & * & 1980 & 1978 \\
\hline Polasek & Metodey & & * & 1958 & 1957 \\
\hline Poole & Gala & Christina & & 2002 & 2002 \\
\hline Porter & Michael & Glenthorne & * & 1965 & 1964 \\
\hline Porter & Nathaniel & John & * & 1993 & 1992 \\
\hline Posaner & David & $\operatorname{Rex}$ & & 1974 & 1973 \\
\hline Potts & Brita & & & 1987 & 1986 \\
\hline Priadko & Mark & Gerard & * & 1991 & 1990 \\
\hline Price & Gareth & James & & 1994 & 1993 \\
\hline Prior & Heather & Margaret & * & 1983 & 1982 \\
\hline Pritchard & Christophe1 & Peter & & 1975 & 1974 \\
\hline Prsa & Mary & & & 1998 & 1997 \\
\hline Pugsley & Sally & Ann & & 1994 & 1993 \\
\hline Quach & To & Lien & & 1999 & 1998 \\
\hline Quek & $\mathrm{Ai}$ & Lin & * & 1981 & 1980 \\
\hline Quirk & Christophe & r William & & 1976 & 1975 \\
\hline Radbone & Jessica & & & 2000 & 1998 \\
\hline Raftery & George & Aldborough & & 1950 & \\
\hline Rasheed & Damon & Lawrence & & 2001 & 2001 \\
\hline Rawlinson & Peter & Edwin & & 1981 & 1980 \\
\hline Razzano & Lou & & & 1984 & 1983 \\
\hline Rechner & Russell & Jay & & 1962 & 1961 \\
\hline
\end{tabular}


Table 11 (continued)

\begin{tabular}{|c|c|c|c|c|c|}
\hline Family name & First name & Othername & & $\begin{array}{l}\text { Year of } \\
\text { raduation }\end{array}$ & $\begin{array}{c}\text { Year } \\
\text { ommenced }\end{array}$ \\
\hline Reynolds & David & Glen & & 1993 & 1992 \\
\hline Richards & Gary & John & & 1985 & 1984 \\
\hline Richardson & Hugh & Stanley & * & 1991 & 1990 \\
\hline Ridgway & Mark & Andrew & & 1989 & 1984 \\
\hline Riegel-Huth & Jill & Penelope & $\#^{*}$ & 1966 & 1965 \\
\hline Rilett & Margaret & Lynn & & 1988 & 1986 \\
\hline Rintoule & Donald & Paul & * & 1979 & 1978 \\
\hline Rintoule & Mark & Clement & & 1980 & 1979 \\
\hline Ritchie & Robert & William & & 1967 & 1965 \\
\hline Rivett & David & William & & 1973 & 1972 \\
\hline Roberts & Philip & Bain & & 1984 & 1983 \\
\hline Robinson & Timothy & & * & 2000 & 1999 \\
\hline Robless & Cosmas & Linus & & 1957 & 1956 \\
\hline Rohrsheim & Geoffrey & Charles & & 1966 & 1965 \\
\hline Rose & Peter & Norman & & 1972 & 1971 \\
\hline Rosser & Bruce & Alexander & & 1973 & 1972 \\
\hline Round & David & Keith & * & 1968 & 1967 \\
\hline Rowe & Lyndon & Geoffrey & & 1976 & 1975 \\
\hline Rowlands & David & Glyn & & 1976 & 1975 \\
\hline Rozenbergs & Ingrid & Ilga & & 1981 & 1980 \\
\hline Ruse & Robert & Stephen & * & 1973 & 1972 \\
\hline Russell & John & & & 1979 & 1978 \\
\hline Safari & Benjamin & & & 2000 & 1999 \\
\hline San & Louis & Patrice & * & 2002 & 2002 \\
\hline Santoro & Matthew & & * & 1984 & 1983 \\
\hline Sarah & Neil & & * & 1962 & 1961 \\
\hline Scarman & Ian & Edwin & & 1961 & 1960 \\
\hline Schubert & Kenton & & & 1995 & 1994 \\
\hline Schutz & Benjamin & & * & 1994 & 1993 \\
\hline Schwarz & Robert & Glen & & 1974 & 1973 \\
\hline Scott & Graham & McLennan & * & 1967 & 1966 \\
\hline Scruby & Bryan & Benjamin & & 1994 & 1993 \\
\hline Semler & Janet & Claire & * & 1962 & 1961 \\
\hline Sharp & Warren & Player & & 1954 & 1953 \\
\hline Shaw & Chi-Kit & Clemence & & 1996 & 1995 \\
\hline Shepherd & Andrew & John & & 2002 & 2002 \\
\hline
\end{tabular}


Table 11 (continued)

\begin{tabular}{|c|c|c|c|c|c|}
\hline Family name & First name & Other name & & $\begin{array}{c}\text { Year of } \\
\text { graduation }\end{array}$ & $\begin{array}{l}\text { Year } \\
\text { mmenced }\end{array}$ \\
\hline Shepherd & Richard & Raymond & & 1970 & 1969 \\
\hline Sheppard & Peter & John & & 1993 & 1992 \\
\hline Sherwin & Rolf & Morton & & 1961 & 1960 \\
\hline Shipley & Glen & Michael & & 2002 & 1999 \\
\hline Short & Christopher & & * & 1985 & 1984 \\
\hline Skladzien & Thomasz & & * & 2000 & 1999 \\
\hline Sloan & Troy & & & 1996 & 1995 \\
\hline Smedley & Matthew & & & 1996 & 1995 \\
\hline Smith & Adrian & Milton & * & 1950 & \\
\hline Smith & Andrew & Burden & * & 1971 & 1970 \\
\hline Smith & Graham & John & & 1973 & 1972 \\
\hline Smith & Gregory & John & * & 1978 & 1977 \\
\hline Smith & Andrew & Keith & & 1983 & 1982 \\
\hline Somerville & Carolyn & & & 1981 & 1976 \\
\hline Sourdin & Patricia & & * & 2001 & 2001 \\
\hline Souvertjis & Peter & & * & 1976 & 1975 \\
\hline Spehr & Martin & Allan & & 1977 & 1976 \\
\hline Stalley & Douglas & John & & 1948 & \\
\hline Stapledon & Nigel & David & & 1976 & 1975 \\
\hline Statton & Paul & & & 1984 & 1983 \\
\hline Stevens & Neville & Robert & & 1973 & 1972 \\
\hline Stewart & Susan & & * & 1987 & 1986 \\
\hline Stocker & Benjamin & & & 2000 & 2000 \\
\hline Struenkmann & Uwe & & & 1967 & 1966 \\
\hline Sturmey & Stanley & George & * & 1951 & \\
\hline Stutchbury & Michael & & * & 1981 & 1980 \\
\hline Subramaniam & Iswaran & & * & 1986 & 1985 \\
\hline Sutherland & Louise & & * & 1999 & 1998 \\
\hline Sutton & Laura & Margaret & \# & 1953 & \\
\hline Swanson & Bruce & & & 1989 & 1988 \\
\hline Synnot & Richard & Monckton & & 1972 & 1971 \\
\hline Tabe & Geoffrey & Ronald & * & 1977 & 1976 \\
\hline Tamms & Vanessa & & & 1997 & 1996 \\
\hline Tan & Kim & Song & * & 1984 & 1983 \\
\hline Tan & Hock & Chuan & * & 1986 & 1985 \\
\hline Tan & How & Teck & & 1986 & 1985 \\
\hline
\end{tabular}


Table 11 (continued)

\begin{tabular}{|c|c|c|c|c|c|}
\hline Family name & First name & $\begin{array}{l}\text { Other } \\
\text { name }\end{array}$ & & $\begin{array}{l}\text { Year of } \\
\text { raduation }\end{array}$ & $\begin{array}{c}\text { Year } \\
\text { commenced }\end{array}$ \\
\hline$\overline{\text { Tan }}$ & Hock & Eng & & 1986 & 1985 \\
\hline Taylor & Gregory & Frank & & 1966 & 1965 \\
\hline Taylor & Andrew & & * & 1995 & 1994 \\
\hline Teh & Joanna & & & 1993 & 1992 \\
\hline Tennant & Paul & & * & 2001 & 2001 \\
\hline Teoh & Eng & Hong & * & 1966 & 1965 \\
\hline Terrell & Richard & Deane & * & 1959 & 1958 \\
\hline Teubner & Jonathan & & & 1991 & 1990 \\
\hline Thompson & Andrew & Philip & & 1988 & 1987 \\
\hline Thomson & Norman & John & * & 1970 & 1969 \\
\hline Thomson & Frances & & & 1992 & 1991 \\
\hline Thorpe & Christopher & Norman & $\#^{*}$ & 1974 & 1973 \\
\hline Threlfall & Peter & Nicholas & & 1975 & 1974 \\
\hline Tiernan & Paul & & & 1985 & 1984 \\
\hline Timckie & David & & & 1997 & 1996 \\
\hline Ting & Martin & Kah Yew & & 1989 & 1988 \\
\hline Toh & Carolyn & & & 1995 & 1994 \\
\hline Toohey & Matthew & Stephen & & 2000 & 1999 \\
\hline Trafford-Walker & Lachlan & & & 1986 & 1985 \\
\hline Tregilgas & Alan & Jeffrey & * & 1972 & 1971 \\
\hline Truong & Phuong & Danielle & $\wedge$ & 2001 & 2001 \\
\hline Truscott & David & Craven & & 1965 & 1964 \\
\hline Tuckwell & Roger & Hamilton & * & 1957 & 1956 \\
\hline Tulsi & Narmon & & & 1988 & 1987 \\
\hline Uylaki & Margaret & Rosemary & & 1982 & 1981 \\
\hline van den Dugen & Peter & & * & 1989 & 1988 \\
\hline van der Lee & Paul & Joseph & & 1976 & 1975 \\
\hline van Elst & Michael & & & 1991 & 1990 \\
\hline Vawser & Noel & Keith & & 1947 & \\
\hline Vitols & Maira & & & 1976 & 1975 \\
\hline Wagstaff & Peter & & * & 1970 & 1969 \\
\hline Wait & Andrew & & * & 1995 & 1994 \\
\hline Walshaw & Timothy & & & 1980 & 1979 \\
\hline Wang & Liang & Choon & * & 2001 & 2001 \\
\hline Warren & Matthew & John & & 1995 & 1994 \\
\hline Waterman & Ewen & Leith & * & 1966 & 1965 \\
\hline
\end{tabular}


Table 11 (continued)

\begin{tabular}{|c|c|c|c|c|c|}
\hline Family name & First name & Other name & & $\begin{array}{l}\text { Year of } \\
\text { graduation }\end{array}$ & $\begin{array}{l}\text { Year } \\
\text { mmenced }\end{array}$ \\
\hline Wawryk & Alexandra & Sophia & * & 1992 & 1991 \\
\hline Wheeler & Andrew & & & 1999 & 1998 \\
\hline Whetton & Steve & & & 1998 & 1997 \\
\hline White & Damien & William & & 1994 & 1993 \\
\hline Williams & Roma & & * & 1945 & \\
\hline Wills & Dawn & Ann & * & 1973 & 1972 \\
\hline Wilson & Benjamin & & & 1994 & 1993 \\
\hline Wing & Ian & Geoffrey & & 1974 & 1973 \\
\hline Wissing & Harry & & & 1977 & 1976 \\
\hline Wittwer & Glyn & & & 1991 & 1990 \\
\hline Wood & Danielle & & * & 2001 & 2001 \\
\hline Woodland & Stephen & & & 1989 & 1988 \\
\hline Worrall & Stefan & John & & 1995 & 1994 \\
\hline Wright & Donald & John & & 1977 & 1976 \\
\hline Wylie & Graham & John & & 1977 & 1976 \\
\hline Yap & Jeffrey & Chin Boon & & 1977 & 1976 \\
\hline Yeo & Mark & Poh Ay & & 1999 & 1998 \\
\hline Young & Ian & Campbell & * & 1965 & 1964 \\
\hline Young & Luke & Chun Wei & & 1999 & 1998 \\
\hline Zielinski & Christopher & & & 1998 & 1997 \\
\hline
\end{tabular}

* First class honours (N.B. perhaps not all are starred)

\# B.A.(Hons) in Economics

$\wedge$ B.Fin.(Hons)

† For those who have no official graduation record in the graduation handbooks, the year commenced is assumed to be the year in which a student studied with his or her fellow graduates. 
Table 12: Titles of theses of Honours graduates, by year of graduation, 1945-2002

1945

Williams, R.

1947

Vawser, N.K.

1948

Bailey, A.P.

Hirst, R.R.

Stalley, D.J.

\section{9}

Cameron, R.J.

Hieser, R.O.

Howard, D.W.D.

Opie, R.G.

\section{0}

Boehm, E.A.

Gilbert, R.S.

Grant, J.McB.

Raftery, G.A.

Smith, A.B.

\section{1}

O'Donohue, R.F.

Sturmey, S.G.

\section{2}

Hill, M.R.

Lewis, R.B.

Penny, D.H.

\section{3}

Gibbs, G.R., A study of the system of administration of the Royal Adelaide Hospital. 


\section{Table 12 (continued)}

\section{3 (continued)}

Griggs, R.L., The economic development of the ship-building industry at Whyalla, SA.

Sutton, L.M.

\section{4}

Hodan, M., The economic analysis of the international wheat agreement of 1949.

Sharp, W.P., The economic effects of controlling dwelling-house rents in South Australia.

\section{5}

Dudzinski, M.L.

Head, J.G.

Medwell, J.G., Australian wage policy between 1929 and 1934.

1957

Ashcroft, J., Business taxable land and air conditioning profits.

Evans, D.W., Long term trends in Australian national income, imports and exports.

Heinrich, H.G., Hire purchase in Australia.

Menadue, J.L., A sketch of central bank control in Australia since 1945.

Robless, C.L., The granting of the protection tariff in Australia.

Tuckwell, R.H., Tariff level indices.

1958

Coat, J.I., Some aspects of Australian inter-capital air transport in the post-war period.

Cockburn, M., The Commonwealth Grants Commission.

Fowler, R.M., Milk supply of Adelaide.

Juhasz, F., The measurement of changes in "capacity to pay" and total available supplies.

Moffatt, G.G., A survey of the development of the tuna fishing industry of South Australia.

Polasek, M., The post-war housing shortage in South Australia. 


\section{Table 12 (continued)}

\section{9}

Lithgow, J.N., The Commonwealth Grants Commission.

Lawrence, M.E. The entry of private savings banks into Australia.

Terrell, R.D., Income distribution and the incidence of income tax.

\section{1}

Hicks, R.P., The developing Australian money market.

Peirson, C.G., The present world shipping depression: its causes.

\section{1}

Scarman, I.E., A company savings function.

Sherwin, R.M., Company takeover bids in Australia 1957-59.

\section{2}

Allen, K.C., Advertising in Australia.

Blandy, R.J., The supply and demand for teaching services in the post-war period in the state educational system of South Australia.

Codd, M.H., Conceptual problems associated with the measurement of changes in the cost of housing accommodation.

Dunstan, G., Forestry in South Australia.

Henderson, J.Y., The effects of price control in South Australia.

Rechner, R.J., Economic validity of principles adopted by the Australian Tariff Board: a study based upon inspection of all case reports from 1954 to late 1960.

Sarah, N., The development of the metal trades award, 1920-30.

Semler, J.C., The wine industry in the light of economic theory.

1963

Davis, R.W., The attempts of the Reserve Bank of Australia to control bank advances in 1960.

Griffiths, P.R., Manufacturer-retailer interaction in television marketing.

Henderson, M.S., Recent developments in Australian hire purchase. 


\section{Table 12 (continued)}

\section{4}

Cook, P.S., Trade associations in South Australia.

Dahlberg, D.L., A statistical investigation of post-war wool supply in Australia and South Australia.

Flew, R.J., The Adelaide taxi-cab industry: costs and profitability.

Henning, G.R., Aspects of South Australian public finance, 1928-32.

Leane, P.A., The economic aspects of parking in the central business district of the city of Adelaide.

Pflaum, P.T., Taxation of real property by local government.

\section{5}

Bee, J.B., Apprenticeship system in South Australia.

Harries, R.I., The major white appliances industry.

\section{5}

Lewis, M.K., Fixed deposits in the Australian banking system.

Porter, M.G., The public debt and liquidity policy.

Truscott, D.C.

Young, I.C., Capital structure and the cost of capital.

\section{6}

Fairbairn, D.F., The measurement of real value added for selected Australian manufacturing industries.

Freney, R.Q., The nature and significance of factoring in Australia.

Mules, T.J., The South Australian potato industry.

Riegel-Huth, J.P., The manufacturing contents of exports.

Rohrsheim, G.C., The utilisation of world iron ore resources, with

particular reference to their use in underdeveloped countries.

Taylor, G.F., Urban land subdivision.

Teoh, E.H., The Malayan rate of interest.

Waterman, E.L., A buffer stock for wool.

\section{7}

Caton, C.N., Seasonal adjustment - A look at the theory and a study of Australian experience. 


\section{Table 12 (continued)}

\section{7 (continued)}

Chua, W.C., The Prebisch thesis and Malayan economic development since independence.

Edwards, R.G., Bank debits as an indicator of economic activity.

Emery, P.J.

Gascoine, D.F., The Victorian proposal for a marginal state income tax in the context of federal-state financial relations in Australia.

Ritchie, R.W., The distribution and marketing of petroleum products in South Australia.

Scott, G.M., The New Zealand-Australia Free Trade Agreement, 1965.

Struenkmann, U., The deposit gap in South Australia.

\section{8}

Bloch, F.A., Australian trading banks' desire for excess liquidity.

Haslam, W.R., A financial analysis of Reid Murray debentures.

Hillier, G.H., An aggregate demand function for fertilisers in Australian agriculture.

Penketh, S.G., The Electricity Trust of South Australia.

Round, D.K., Marketing margins for lamb in South Australia.

1969

Eckermann, L.D., The desirability of protection in Papua and New Guinea.

Edgar, R.J., The market performance of the Australian banks.

Hirst, J.A., Effective protective rates.

O'Brien, K.P., A central bank in the territory of Papua and New Guinea: Now or later?

1970

Gan, H.B., The possible relationship between industrialization and unionisation in the underdeveloped countries of Asia and its application to Malaya.

Hall, A.D., Spectral analysis and economics. 


\section{Table 12 (continued)}

\section{0 (continued)}

Lean, D.R., The role of government borrowing overseas with particular reference to the balance of payments.

Maguire, G.R., Fiscal policy in Australia 1928-29 to 1938-39.

McMurtrie, J.M., The supply of and the demand for academic economists at Australian universities, 1955-65.

Plews, J.N., The historical relativity of economic theory.

Shepherd, R.R., The demand for motor vehicles with special reference to the effect of consumer credit.

Thomson, N.J., Bulk grain storage at Crystal Brook.

Wagstaff, P., Regional multipliers.

\section{1}

Benger, B.G., The effects of relative price changes on the aggregate saving-income ratio.

Cornelius, G.L., Housing finance in Australia.

Knapman, B., Economists as sociologists: an historical study of the relation between economic theory and economic sociology, with reference to modern growth theory.

Martin, G.S., Manpower projections for specific occupations: a case study.

Officer, S.J., The principles of computer feasibility studies and their application.

Pascoe, M.S., Box-Jenkins time series analysis and economics.

Smith, A.B., The problem of capital in the neo-classical theory of distribution.

1972

Barrett, S.M., The production of beef on South Australian dairy farmers.

Danaro, G., A study of the demand for currency in Australia 191069.

Fuller, D.E., The SA chicken meat industry.

Hastings, T.R., The management of a fishery resource: cray-fishing in SA.

Leane, G.W., The SA motor vehicle industry.

Papadopoulos, C., A model of the Australian meat market. 


\section{Table 12 (continued)}

\section{2 (continued)}

Partington, S.J., An examination of the Commonwealth and State Housing Agreement.

Rose, P.N., Private time-savings in transport investment appraisals: a review.

Synnot, R.M., A concept of income and value and its application.

Tregilgas, A.J., Regional unemployment differences in Australia, 1954-70.

1973

Baker, W.R., Current and prospective employment opportunities in the Mount Gambier area.

Best, S.P., The interrelationship between capital inflow and monetary policy in Australia.

Bulbeck, M.C., Equality of education: a study of the distribution of education among children between the ages of five and thirteen in South Australian state schools.

Chan, P.H., A heuristic approach to the stock demand for farm tractors in Australia.

Hambley, G.V., Investment criteria in South Australian railway construction, 1856-1891.

Kirkpatrick, G.H., The stockfeed processing industry: structure and conduct.

Kwong, L.L.W.

McLeod, P.B., Effective protective rates and profitability of manufacturing industry.

Oakley, A.C., The theory of the rate of profits in English economic thought.

Paterson, R.P., The nature of competition in the Australian automobile industry, 1956 to March 1972.

Rivett, D.W., The demand for savings bank balances in suburban market areas.

Rosser, B.A., Disclosure by life offices in Australia.

Ruse, R.S., A discussion of monetary policy indicators in Australia. 


\section{Table 12 (continued)}

\section{3 (continued)}

Smith, G.J., The determinants of residential land prices.

Stevens, N.R., Land development costs and their relation to land price.

Wills, D.A., The imposition of excise duty and "ordinary" wine sales.

\section{4}

Bailey, G.A., The impact on the Australian canned pear industry of Britain's entry into the European Economic Community.

Branch, S.R., Economics of scale in the production of cement at the Adelaide Cement Company, 1961-70.

Byrne, J.L., Abattoirs expansion.

Comber, R., The effect of investment planning techniques on declining profitability in a major Australian chemical company during the 1960's.

Kain, J.D., Transport policy in South Australia, with special reference to the railways in the competitive transportation environment.

Lim, G.C., An application of the Linea hypothesis of the money supply to the Australian case.

Mann, E.J., The influence of price, incentive and allocation systems upon the performance of the Hungarian enterprise: 1950-67.

Posaner, D.R., The South Australian beef cattle industry: some estimates of farmer's response to price.

Schwarz, R.G., The income velocity of money in Australia, 1952-72.

Thorpe, C.N., The economics of family planning in South Australia.

Wing, I.G., The role of the Commonwealth Development Bank in the market for long-term rural credit.

\section{5}

Arnold, A.J., Monetary velocity and the investment multiplier, Australia, 1950-73.

Barber, R.C., Investigation of the prospects for significantly increasing the processing of wool in Australia.

Cowan, P.C., An example if machinery replacement analysis. 


\section{Table 12 (continued)}

\section{5 (continued)}

Evans, W.D., The economics of industrial effluent control, incorporating a case study of Lake Bonney.

Findlay, C.C., The effect of conditions in the chicken meat industry on retail red meat prices.

Holthuyzen, M.R., Microeconomics of unbalanced growth: a critique of the consequences of unbalanced growth as postulated by W.J Baumol.

Inverarity, S.F., An analysis of tax farming.

Lawriwsky, M.L., Pricing in the smallgoods industry.

Leske, J.R., "The inconsistent trinity": recent Australian experience.

Liebelt, G.R., Construction of an index ranking schools: an application of multivariate data analysis.

Lim, S.G., Muda irrigation project.

Markovic, M., The impact of the removal of the dairy bounty.

Martin, G.I., Speculation in the market for suburban residential allotments: the reasons for its existence, its social benefits and social costs.

Parham, D.J., Aspects of building society behaviour in Australia.

Pentelow, D.B., Merger and takeover activity in Australia, 1969-72.

Pritchard, C.P., The social relevance of cost-benefit analysis.

Threlfall, P.N., Competition and the changing structure in grocery distribution: a study into the South Australian retail grocery trade.

\section{6}

Andary, J.D., Stability and growth in the Australian citrus industry.

Cheok, A.S., Marx's theory of exploitation and the so-called transformation problem: a survey.

Georgiou, V., Solar power as alternative energy source: an investigation into the economics of solar water heating in Australia.

Gobbett, D.J., Australian railways in the $19^{\text {th }}$ century: some primary effects.

Goward, P.J., The influence of trade unions on the level of wages of their members in South Australia, 1964-1971. 


\section{Table 12 (continued)}

\section{6 (continued)}

Haddy, B.R., King William Street trams: a cost-benefit appraisal of the extension of the Glenelg tramway northwards.

Harriss, J.M., Dairy industry reconstruction since 1970, with particular emphasis to South Australia.

Hodder, M.W., The economics of paper recycling in South Australia. Johnson, G.N., The demand for and supply of money in Australia.

Laidlaw, S.M., The implications of preventing the quarrying of stone in the Adelaide hills face zone.

Lane, C.G., A cost-benefit analysis of constructing a bridge at Berri.

Pearce, D.K., The concept of the effective rate of protection, with specific reference to the Australian tobacco industry.

Quirk, C.W., An evaluation of the Australian tariff preference scheme for less-developed countries.

Rowe, L.G., An examination of the view that the Australian arbitration framework is more egalitarian than other systems.

Rowlands, D.G., Aspects of Adelaide used car market.

Souvertjis, P., Explanatory ability of existing models of aggregate investment in Australia.

Stapledon, N.D., Aspects of the Australian cement manufacturing industry, with special reference to South Australia, 1890-1939.

van der Lee, P.J., The economic base model: an evaluation of the method of regional analysis as applied to the south east region of South Australia.

Vitols, M., Factors influencing oil exploration in Australia: a historical view.

\section{7}

Angove, M.R., Immigration and employment in Australia.

Barton, J., Short-run influences on savings behaviour: the Australian evidence.

Boxall, C., The role of specific purpose grants in financing the states.

Butler, D.J., Asset valuation, income determination and instalment credit.

Cannavo, S.J., A competitive model of the Adelaide media industry, 1971-1975. 


\section{Table 12 (continued)}

\section{7 (continued)}

Fraser, R.W., Production functions, ordinary least squares and the fluid milk sector of South Australia since 1965.

Gaston, N.G., Is Australia experiencing a profits crisis analogous to that of the United Kingdom?

Hefford, C.B., The welfare loss due to market power in Australian manufacturing industries.

Hubbard, D.J., Parking policies and traffic congestion in the central business district of Adelaide.

Lawrie, G.A., Estimating the contribution of investment to growth: an econometric analysis of Australia, 1861 to 1938-39.

Need, M.B., An economic study of voluntary social agencies.

Spehr, M.A., Sensitivity testing of regression models of the Reserve Bank and the Treasury: dwelling investment.

Tabe, G.R., Current controversies in the stevedoring industry.

Wissing, H., A cost benefit analysis of the withdrawal of a railway service: a study of the Victor Harbor-Mount Barker junction branchline in South Australia.

Wright, D.J., A comparative study of the rate of increase in metropolitan house building costs in Australia, 1971-1975.

Wylie, G.J., The effects of the 25 per cent across the board tariff cuts of 1973, with special reference to employment.

Yap, J.C., Comparing the 1960 and 1974 credit squeeze in Australia.

1978

Bitter, S., The Adelaide restaurant industry.

Brownbill, M.G., Prospects for the Port Adelaide container terminal.

Burgan, B., A mean-variance approach to hybrid corn diffusion.

Denton, S., Correlates of job satisfaction among migrant workers in South Australia.

Donnelly, R.N., The nature and origins of the marginal revolution.

Evens, S.M., Crowding out: theories and evidence.

Gibbs, I., Gambling expenditure in South Australia, 1967-68 to 1975-76.

Lee, T.J., An economic appraisal of the metal finishing industry.

Lum, F.H., The economics of family planning in Singapore.

Smith, G.J., The economics of public housing policy, South Australia, 1936-76. 


\section{Table 12 (continued)}

\section{9}

Chapman, P.N., Ricardian economics after Ricardo.

Coffey, P.M., The determinants of private foreign investment in Australia, 1966-67 to 1975-76.

Fedorowicz, T.K., Input output in Australia: its uses and limitations. Hart, L.C., Criteria for identification of transport disadvantaged areas.

Lai, H.K., On Marx's law of the tendency of the rate of profit to fall.

Macrow, M.S., Trade Practices Commission decisions on merger proposals in SA primary industry.

McCabe, M.D., The relationship between industry concentration and profitability in Australian manufacturing industries.

Mitton, J., Managed funds in Australia.

Piovesan, F., Tests of monetary disequilibrium in Australia.

Rintoule, D.P., Pricing of electricity in South Australia.

Russell, J., The changing structure of the South Australian wine industry.

1980

Aungles, P.B., The causes of the increase in Australian unemployment in 1974.

Bansemer, P.G., The preferential brandy excise and the Riverland grape grower.

Belchamber, G., Some observations on the recent RobinsonGaregnani exchange.

McCarthy, P., Prospective developments in the Australian forward exchange markets.

Miller, B.L., On the contributions to economics of Herbert A. Simon.

O'Loug, L.M., The performance of fiscal stabilization in Australian post-war recessions.

Palmer, V., Housing finance in the 1970s: South Australia.

Pocock, B., Farm build up and economics of size in the Mallee area of South Australia.

Rintoule, M.C., An Investigation into optimal inter-modal prices for public transport in Adelaide. 


\section{Table 12 (continued)}

\section{0 (continued)}

Walshaw, T., The integration factor: a measure of financial integration between the world's financial markets.

\section{1}

King, Y.A., The grape growing industry in the southern vales, 19731980.

Lau, S.L., Assessment of the Australian generalised scheme of preferences for ASEAN in manufactures.

Lim, S.H., Married women in the part-time workforce: an Australian study 1970-1979.

Lockett, P., Milton Friedman and economic policy: a study of the relationship between economic analysis and ideology.

Molloy, S.F., The invisible hand from Adam Smith to Fred Hirsch.

Neo, Y.W., Diversification in Australian manufacturing industries.

Parkinson, M., The theory of effective demand.

Philipson, M.G., Discussion of an efficient strategy to optimize the consumption on non-renewable energy forms used in the heating of domestic water in South Australia.

Quek, A.L., The role of education in production with emphasis on its allocative effects on agriculture.

Rawlinson, P.E., Technology and the control and coordination of the production process.

Rozenbergs, I.I., Consumer protection: silk purse or sow's ear?

Somerville, C., A cost-benefit appraisal of the proposed construction of the St. Peters bicycle track.

Stutchbury, M., State government industrialization strategies in South Australia under Playford and Dunstan.

\section{2}

Bartholomew, D.J., The Adelaide milk processing industry: the impact of merger activity and implications for antitrust legislation.

Bigg, S.A., The interest rate futures market as an indicator of interest rate expectations.

Coker, C.J., The substitutability of money and near-moneys. 


\section{Table 12 (continued)}

\section{2 (continuued)}

Johns, J., Financing the Commonwealth budget deficit.

Kalisch, D.W., The output loss from unemployment.

Keese, M., Arbitration and conciliation in South Australia, 18901927.

Kerin, P., Regulation of financial reporting: the enforcement of accounting standards.

Olekalns, N., The monetary approach to the determination of the exchange rate.

Uylaki, M.R., An explanation of student labour force participation, 1970-1980: the supply response of teenage labour to changes in unemployment benefits.

\section{3}

Easton, S.A., The identification of homogeneous risk classes.

Lim, R.S., The modern Classicals on Keynes: a critique.

Prior, H.M., Gender differences in quit behaviour: a study of Australian government employees over the 1970s.

Smith, A.K., South Australia: industry structure and the national recession, 1974-1980.

\section{4}

Abraham, D.R., Contestability theory and Aussat: an exposition, application and critique.

Archer, B.A., Interstate migration in Australia.

Bull, M.C., Some economic implications of direct foreign investment, with specific reference to multinational corporations: Australia as a host.

Butler, M., Australian foreign exchange markets: speculative and interest arbitrage effects on deviations from interest rate parity.

Cooper, A.M., Liability management and its implications for the banking firm and monetary control.

Cormie, B.J., Blood transfusion services in South Australia: an economic appraisal. 


\section{Table 12 (continued)}

\section{4 (continued)}

Crowle, C.T., The course of pay in the South Australian public service.

De Picot, A.S., Economies of scale in branch banking.

Evans, S.F., Tax-based incomes policies: a cure for Australian stagflation.

Francis, M.M., An analysis of teenage unemployment durations and the effects of unemployment benefits.

Hudson, D.H., Inflation, uncertainty and investment.

Laurencis, A., Comparative advantage and the world steel industry, 1955 to 1980.

O'Dea, D.C., The effect of inflation on the distribution of income and wealth.

Razzano, L., Managing a firm's foreign exchange exposure.

Roberts, P.B., Bank account debits tax and financial institutions duty.

Santoro, M., The Campbell inquiry and the Australian housing construction industry's stability problem.

Statton, P., The development of the bauxite/aluminium industry in Australia: a critical analysis of its implications, the influence of transnational corporations and the adequacy of government policy.

Tan, K.S., The term structure of interest rates in the seventies: an empirical investigation.

\section{5}

Amstad, I.C., A cure for stagflation? An analysis of the macroeconomic implications of gain-sharing.

Baker, M.A., Returns from investment in university degrees: an analysis of three predictions from the human capital model.

Bald, A.J., Analysis of the arguments for and against foreign exchange market intervention.

Bannister, G.C., The increase of unemployment in Australia, 19811983: facts, figures, theories, thoughts.

Bastin, L.D., The emergence of unemployment as an economic policy issue: 1880-1890. 


\section{Table 12 (continued)}

\section{5 (continued)}

Craig, D., A comparison of the merger and diversification strategies of three Australian companies.

Hollow, B.D., A performance comparison of conglomerate and nonconglomerate firms in Australia.

Lim, S.H., The portfolio behaviour of life insurance companies in Australia.

Ong, B.P., The cyclically adjusted budget deficit.

Parker, D.J., An interdisciplinary approach to choice behaviour: the use of the experimental methods of operant psychology to test economic theory.

Richards, G.J., Federalism as a device to limit political failure.

Short, C., The hedging effectiveness of share price index futures.

Tiernan, P., Price dispersions in the retail markets: theories and evidence.

\section{6}

Andersen, M.D., Models of trade union influence on the level of wage inflation.

Chia, T.T., Alternative approaches to the theory and practice of crop insurance.

Chua, K.H., A study of multinational banking: its evolution and growth.

Coghlan, J.F., An analysis of property trusts in Australia.

Crosby, M., School retention and part-time work: an attempt to isolate the effect of an explanator of school retention.

Duldig, P., The extension of private health insurance coverage in Australia: public problem or private choice?

Edwards, C.T., Employment and hours of work in South Australian manufacturing.

Fong, Y.F., Trans-sectorial influence, ultra-rationality, and household savings.

Gerhardy, P.G., The impact of the issue of statement of accounting standards AAS12 on the presentation of the statement of sources and applications of funds in Australian financial reports. 


\section{Table 12 (continued)}

\section{6 (continued)}

Grbin, D., An empirical investigation into scale economies in South Australian credit unions.

Hancock, J., The performance of migrants in the Australian labour force.

Konstas, M.D., China's "open door" and Asia-Pacific structural change: a case study of import competition and policy challenges for Australia's clothing industry.

Lim, E.L., An econometric model of South Australia.

Lim, G.H., The role and effects of penalty rates in the hospitality industry of South Australia.

Lim, P., Wages policy in Singapore: an appraisal.

Lye, J.V., Taxation of international interest income flows: the case of the Australian interest withholding tax.

Maloney, R.J., What factors have determined spectator attendances at test cricket matches in Australia, 1920-21 to 1983-84?

McDonald, S.R., Tax reform, rhetoric and the rental market.

Morissey, M.J., Changes in the relative importance of deferred credits disclosed amongst liabilities in the published financial statements of Australian public companies, 1974 to 1984.

Phua, K.K., A 'hazard' analysis of the distribution of unemployment.

Subramaniam, I., A study of the measurement of bank output.

Tan, H.C., Temporal price behaviour in the Australian financial futures market.

Tan, H.T., The personal income tax and the flat and linear tax alternatives.

Tan, H.E., The impact of trade taxes: the case of research CESS on Malaysian rubber exports.

Trafford-Walker, L., Japanese beef import policies, 1970-83: an examination of global and bilateral resistances to beef trade.

\section{7}

Bassanese, D.J., Incidence theory and the F.B.T. debate. 


\section{Table 12 (continued)}

\section{7 (continued)}

Gaudry, B.P., The efficiency and effectiveness of secondary schools in South Australia: a comparative study of government and non-government schools.

Harcourt, T., Unemployment, the economists, and the 1920's: the Australian dilemma.

Ivanbrook, C.L., The determinants of the price of quota: the textile, clothing and footwear sectors of the Australian economy, 1982-1986.

Johnson, C.W., T.A.B. distribution of funds and its economic implications for the racing industry and state government revenue in South Australia.

Lamp, R.A., A private-interest theory approach to the 1983 steel industry plan.

Lyons-Davis, A., Electronic funds transfer systems and the household transactions demand for money.

Potts, B., Estimating the supply of labour by women 1978 to 1986: a disaggregated approach.

Stewart, S., Unemployment in Australia: an econometric investigation.

\section{8}

Alexander, M.J., The effect of unemployment benefits on the level of aggregate unemployment.

Britten-Jones, M., Testing theories of the efficiency of future markets.

Cully, M.R., The South Australian experiment with industrial democracy.

Davey, O.L., How the forward exchange rate is determined.

Debelle, G.L., Why has employment grown?

Forbes, A., The resource rent tax in Australia.

Rilett, M.L., Urban housing in India: the problem, causes and solutions.

Thompson, A.P., Financial reporting by superannuation plans.

Tulsi, N., Lancaster's theory as applied to a new consumer durable: the compact disc player. 


\section{Table 12 (continued)}

\section{9}

Chiang, Y.C., Exchange rate determination: the case of Singapore.

Lee, Y.H., The impact of changes in accounting standards on the format of funds statement: 1985-1987.

Newman, M.E., What are the determinants of arrivals from New Zealand to Australia?

$\mathrm{Ng}$, S.N., Labour skill specificity and manpower policy in Singapore.

Nicholls, M., Impact of deferred tax credits on the balance sheet in 1980 and 1987.

Omar, L., An analysis of the brushcutting industry in South Australia.

Ridgway, M.A., Regulation of the South Australian building industry, with special reference to producer licensing.

Swanson, B., The theory of co-integrated time series and its application to nominal wage determination.

Ting, M. K.Y., Capitalisation of finance leases: a behavioural and attitudinal investigation.

Van den Dugen, P., Indices of international competitiveness and trade performance, with special reference to Australian exports.

Woodland, S., Agriculture and the macroeconomy: a case study of the European community market for common wheat with reference to the current round of multilateral trade negotiations.

\section{0}

Brummitt, W., China's economic growth, agricultural selfsufficiency and its livestock and grain sectors.

Bruten, G., Current account adjustment: what is the role of fiscal policy?

Campi, T., Unemployment and property crime: South Australia during the depression.

Gibbard, P.J., The domestic distributional impact of commodity price stabilization in an open economy. 


\section{Table 12 (continued)}

\section{0 (continued)}

Jones, M.L., Economic significance of tourism expenditure in South Australia for 1985/86.

Kinch, A.M., The efficacy of discriminatory public procurement as a tool in industry policy.

Measday, W.H., Factors affecting the development of the EuroAustralian dollar bond market.

Meier, D.C., East-West European trade: an analysis of the special case of East and West Germany.

Myatt, J., An analysis of direct intervention in the foreign exchange market by the Reserve Bank of Australia, 1984-1989.

Newitt, D.G., A consideration of the accounting standards overload issue and the recognition and identification of reporting and non-reporting entities to enable the adoption of differential report requirements in practice.

1991

Carter, S.D., Corporate treasury performance measurement.

Chalmers, M.J., Efficiency in public transport pricing, service levels and subsidy levels.

Hales, B., The Australian offsets program: an evaluation.

Hempton, J.I., The case for a broad-based consumption tax.

Priadko, M.G., The effects of deregulation and competition on public enterprise performance.

Richardson, H.S., Iron and steel production and trade patterns in China.

Teubner, J., Research and development expenditure by the Australian Wool Corporation and its effect on the market power of the Australian wool industry.

Van Elst, M., Cable television: market provision of an excludable public good with program selection.

Wittwer, G., Price stabilisation of coffee in Papua New Guinea. 


\section{Table 12 (continued)}

\section{2}

Balchin, J.J., The determinants of labour absence.

Cardak, B.A., Does Australia have a long term current account problem? Intertemporal substitution, theory and Australian evidence.

Eckermann, S.D., The market for overseas students in Australia.

Giesecke, J.A., The declining middle class.

Jackson, M.A., Expanding and examining Baumol's macroeconomics of unbalanced growth in the Australian context.

Keda, S., International impact of reforms in Eastern Europe.

Kim, Y., Political motivations of price distortions in agricultural protection: the case of Korean beef industry.

Thomson, F., Intergovernment funding of tourism on Kangaroo Island.

Wawryk, A.S., The determinants of imports and profits in Australian manufacturing industries.

1993

Della-Torre, K., Will Eastern Europe converge? Problems and policy.

Harmstorf, H.N., Interstate wage relativities as determinants of South Australian manufacturing: an interstate comparison.

Holdich, T., A comparison of strategies aimed at repaying the wool growers' debt to the government.

Hutchins, D.A., South Australia's Technology Park policy: a critique. Kossen, M., The liberalisation of the Japanese rice market.

Layton, T., The economics of recycling: an application of a model to paper.

Orr, D., Findings of post-float speculative inefficiency of the USD/AUD: of risk, irrationality and pesos.

Peak, G., International trade in computer software.

Phipps. S.L., An empirical investigation of the hypothesis of increasing non-renewable natural resource scarcity. 


\section{Table 12 (continued)}

\section{3 (continued)}

Porter, N.J., The application of an integrated linear programming/input-output model to study the impacts of a pollution control policy hierarchy on the Riverland.

Reynolds, D.G., Competitive tendering: Adelaide metropolitan bus services.

Sheppard, P.J., Price stability and the Australian constitution.

Teh, J., Export education services: effects on the Malaysian demand for Australian education services.

\section{4}

Appleby, S.L., The economic value of domestic cats.

Bowley, C.J., Has the increase in job security and worker welfare provisions increased the proportion of casual jobs to total jobs since 1970 ?

De Roos, N., A game theoretic analysis of the market for pay television in Australia.

Findley, N.M., The private demand for higher education: a case study of the University of Adelaide and the Flinders University of South Australia.

Flavel, M.J., Returns to research and development in Australia.

Heddle, G.R., Theories of credit rationing with an empirical application to the Australian home mortgage market.

Howarth, P., Eastern multinationals through western eyes.

John, C.M., What can economics say about equity? A thesis with special relevance to South Australian public transportation.

Kourteff, M., Industrial research and development in Australia.

Krieg, A.R., The welfare implications of China's reform process: an agricultural household model approach.

Martyn, B.D., Distortionary policies and the average age of the Australian vehicle fleet.

Matters, A., The coal vend cast: collusion or competition?

Miki, M., Human resource management policies and labour turnover: the case of Mitsubishi Motors Australia.

Price, G.J., Explaining the Australian multinational enterprise: a firm comparison. 


\section{Table 12 (continued)}

\section{4 (continued)}

Pugsley, S.A., The scope for demand side management in the Australian electricity industry.

Schutz, B., The market for economics: Australian labour economists and the art of persuasion.

Scruby, B.B., Technological change in the major Australian banks and implications for market concentration.

White, D.W., A cost-benefit analysis of the Eyre Peninsula grain transport system.

Wilson, B., Eliciting Preservation values using the contingent valuation method.

\section{5}

Clarke, P., Gender bias in union/non-union wage differentials.

Grdosic, M., Sunk costs, hysteresis, and export facilitation: a conceptual synthesis used to analyse the automotive component producers' export success.

Liew, V.P., Financial integration in the Asia-Pacific: an Australian perspective.

McGuire, P.J., ASEAN: its evolution towards free trade and the prospects for including other economies.

McKenna, D.S., The impact of foreign direct investment on the levels of employment within the Australian manufacturing sector.

Moyle, G., A contingent valuation of Craigburn farm.

Schubert, K., The expected resources boom of the 1980s and the structure of the Australian macroeconomy: a modified booming sector perspective.

Taylor, A., The Trade Practices Commission: authorised mergers and the public interest.

Toh, C., A new way of funding public hospitals.

Wait, A., Up in smoke: an economic analysis of smoking and public policy.

Warren, M.J., The impact of container deposit legislation on kerbside recycling.

Worrall, S.J., Capture and culture: the ocean fishery and aquaculture. 


\section{Table 12 (continued)}

\section{6}

Allen, C.L., The economics of slowing global warming: an analysis of what determines an appropriate policy for reducing $\mathrm{CO} 2$ emissions.

Dare, A.J., The economics of untied versus activity-focused aid: a case study of Papua New Guinea's aid program from Australia.

Gray, M., A theoretical and empirical study of labour demand under imperfect competition.

Graziani, R., An investigation into fiscal indicators.

Harrington, M., The economics of government assistance to plant research and development.

Koster, M., The economic aftermath of the peaceful revolution in the former Deutsche Demokratische Republic: east-west migration and the German monetary union.

Martyn, J., A model of utility maximisation for religion.

Milnes, S., South Africa: the effect of an international investment boycott.

Nelson, S., An analysis of the demand for pay television.

Ordon, A., India: steeled for the 21st Century.

Shaw, C-K.C., China's foreign exchange policy under economic reform since 1979 .

Sloan, T., A study into the employment and unemployment effects on minimum wages: theory and evidence.

Smedley, M., Budgetary and monetary aspects of east-European integration into western markets.

1997

Anderson, J.L., The elderly and computer education: a logit model of influences on willingness to pay.

Chapman, L., Analysis of the employment effects of incentives to the South Australian information technology industry.

Emeny, M., The political determination of environmental regulation. Ewmery, D., Salinity in the River Murray: the game between states.

Feijen, N., An analysis of the effects on Australia and New Zealand from an expansion of NAFTA to include Chile. 


\section{Table 12 (continued)}

\section{7 (continued)}

Gosnold, P., Public housing allocation and the need for change.

Hahn, P., Economic growth and the environment: the case of Korea.

Jordan, D., Financial deregulation and bank risk.

Lawson, E., Japan's direct foreign investment: does the motivation for outward direct foreign investment in Japan differ from that of the United States?

Lindsay, S., A historical study of the contribution of public infrastructure to economic growth in Australia.

Matters, S.J., The trade restrictiveness index: an Indonesian application.

Tamms, V., Issues in bilateralism: a case study of air transport within the US- Japan Relationship.

Timckie, D., Factors influencing the probability of moving from casual employment to full-time permanent employment.

\section{8}

Berger, N., International recyclable hazardous waste trade with non-OECD countries has come to an end: who stands to gain and lose?

Bishop, M.P., International connections: the sovereign debt of Australia in the 1890s.

Crisci, P., Random breath testing in South Australia: is it effective in reducing road fatalities and casualties?

Duerrwald, K.I., Valuing bag limit increases for King George Whiting and Southern Sea Garfish.

Gladigau, S., A different game altogether: the peculiar characteristics and structure of a professional team sport and its industrial relations system, utilising professional Australian-rules football as a case study.

Goldsworthy, B.K., How has the NAIRU evolved in Australia?

Hall, D., The efficient market hypothesis in the context of Australia's financial markets.

Hester, S.T., Land degradation and agriculture in Australia.

Heywood, T., The implications of ageing for Australia: problem or opportunity? 


\section{Table 12 (continued)}

\section{8 (continued)}

Howarth, N., The economics of tradeable water entitlements and irrigation sector reform.

James, S., Economic analysis of quarantine, with an application to Australia's ban on banana imports.

Kain, M., Australian exports and foreign and domestic activity.

Kanjanasupak, L., Time-charging local calls and welfare: a case study of Australia.

Lacar, F., Tests of post-float speculative efficiency in Australia (1983-1991) using the Swiss franc/ AUD exchange rate.

Munchenberg, R., An analysis of the development import finance facility in promoting the export of capital goods.

Petrus, N., A model of religious participation.

Prsa, M., Liberalisation of trade in basic telecommunications: is the GATS the best route?

Whetton, S., Is the natural rate historically based? Testing for the presence of hysteresis in the Australian labour market.

Zielinski, C., Heroin consumption and crime: the effect of the methadone and needle exchange programs.

\section{9}

Bowes, C., Uncorking European wine policies: to what extent has the European Union liberalised its market for wine?

Day,G., Transmission of monetary policy across Australian industry.

Harvey, S., The economics of a common property resource: a case study of water use and policy options in the Southern Vales.

Kosturjak, A.M., An economic investigation into parallel imports of sound recordings with regard to Australia.

Lim, M-K.J., The East Asian stock markets: efficiency and portfolio.

Osmond, R.G., Policy changes and cycles in the Australian wine industry: the interwar period.

Pedler, M., The removal of restrictions on store trading times in South Australia: an analysis of the large retailer.

Quach, T.L., Does firm size matter? A case study of the South Australian smallgoods industry. 


\section{Table 12 (continued)}

\section{9 (continued)}

Sutherland, L., An assessment of the 1998 Australian radio spectrum auction.

Wheeler, A., Is the tiger all skin and bone? An examination of the tiger's path to extinction and insight into corruption.

Yeo, M.P., Road to financial liberalization (pre-conditions for successful financial reforms).

Young, L.C-W., The Asian financial crisis: testing the corrupted miracle.

\section{0}

Blias, A., The economics of resources with stock and flow values.

Bratkovic, L., Contagious currency crises in emerging markets.

Caruso, D., Exchange rate pass-through for Australian manufactured imports.

Croser, J., Human capital in East Timor: the role of education.

Davis, B., Strangulation and decoration: analysing the economic costs of weeds in barley crops on Yorke Peninsula.

De Blasio, L.D., Dealing with the State Bank loss.

Dolman, B., The demand for alcohol, tobacco and marijuana: some econometric evidence.

Dugian, V., Australian parents' allocation of time towards dependent children.

Freak, B., An understanding of the probability of long-term unemployment in adults with and without dependent children.

Herbert, M., Deforestation - evidence for concern: an empirical analysis of the relationship between economic growth and deforestation.

Jacobi, C., An endogenous theory of retail sales.

Kok, S.S., The economics of geographical indications: a case study of the bilateral EU - Australia wine agreement.

Lawson, J., Does monetary policy have a differential impact on the Australian states?

Martin, R.S., Ownership structure and corporate governance in China. 


\section{Table 12 (continued)}

\section{0 (continued)}

Nukic, S., Is FDI a safer form of finance? Insights for Malaysia.

Piper, D., Exchange rates and stock prices: the Australian evidence.

Radbone, J., How to price access to Melbourne's rail infrastructure.

Robinson, T., Water privatization through franchising: the South Australian experience.

Safari, B., Family assistance with minimum pressure on parental labour supply and child care choices.

Shipley, G., Signalling in Australian price-fixing.

Skladzien, T., Natural resource endowment and economic growth.

Stocker, B., Uncovering the sources of gains in horizontal takeovers: a closer look at the market for corporate control in Australia.

Toohey, M.S., Explaining the labour market outcomes of the former John Martin's workers.

\section{1}

Jenkins, A-S., Deforestation in rural Nepal: an economic model.

Johnson, B., Emissions reductions: the Kyoto Protocol and the Australian domestic coal.

Kahland, A., The wrath of grapes: a study of risk and the prevention of Phylloxera.

Lau, H.W., Divided discount models: theory and applications.

McArthur, T., Trade, growth, inequality and poverty.

Mitchell, A., The determinants of the recent productivity growth in the Australian automotive component industry: an econometric approach.

Nicolle, T., Co-movements between stock prices and bond yields in Australia: can the present value models be saved?

Norman, D., The zero bound on nominal interest rates: implications for Australian monetary policy.

O'Rourke, D., Some features of growth in urban centres and localities in Australia.

Rasheed, D.L., Australian rules football: a study of market efficiency and optimal betting techniques.

Sourdin, P., The properties of bootstrap tests for shrinkage estimators: an application to ridge regression. 


\section{Table 12 (continued) \\ 2001 (continued)}

Tennant, P., Investigating the recent behaviour of the Australian dollar: has the TWI entered the twilight zone?

Truong, P.D., Proficient funds transfer pricing system: a case study. Wang, L.C., The relationship between TER and university performance.

Wood, D., Wine quality, weather and technological change: a 2002 hedonic price study of icon red wines.

Bastian, B.R., Interest rate swap spreads: an empirical analysis into the dynamic linkages.

Brooks, A.J., Strategic behaviour and market entry in a deregulated electricity pool.

Doherty, L.N., An analysis of integrated conservation and development projects.

Evans, S.B., Optimal monetary policy rules in Australia.

Fowdur, L., Trade liberalisation in the presence of factor market distortions: the case of Sri Lanka.

Giles, S.W., Two's company, three's a crowd? An insight into the Australian domestic airline market.

Gordon, W.R., Illicit drugs and employment status: new evidence from Australia.

Lawson, J., Does monetary policy have a differential impact on the Australian states?

Nguyen, H.M., Endogenous growth and environmental pollution: a two-country model.

Phong, T.H.N., The determinants of wage mobility: an investigation of recent migrants to Australia.

Pincombe, A.M., Cost of disease and demanding performances: the economics of Australia's symphony orchestras 1972-98.

Pobke, C.P., The return to education for indigenous Australians.

Poole, G.C., The determinants and implications of restrictive immigration policy.

San, L.P.K.F.Y.C., On choosing the optimal level of significance for the Hausman test: sample size considerations.

Shepherd, A.J.S., The indirect trade effects of Australian tied aid.

Shipley, G.M., Signalling in Australian price-fixing. 
Table 13: Alphabetical list of students completing a Graduate Certificate, Graduate Diploma or Applied Masters, 19902002

Year Family
name

1992 Allan

1996 Alvaro

1992 Aplin

1992 Aust

1993 Bonnici

1991 Buckby

1992 Carter

1993 Castellano

1994 Cernaz

1998 Chen

2000 Chen

1994 Clemenger

2000 Cui

1999 Dang

1999 Ding

1999 Doble

1999 Doble

1991 Donato

1998 Dong

1997 Du

2000 Duffy

1995 Feast

1993 Findlay

$1998 \mathrm{Fu}$

2002 Han

1997 Haq

1997 Hong

$1999 \mathrm{Hu}$

1998 Huang

1998 Ietaake

1993 Jackson

2000 Jiang

1997 Jiao
First names

Donald Peter

Anthony

Geoffrey Lynton

Terence

Christopher Armando

Malcolm Robert

Norris George

Francesco

Randi

Chang

Wenlin

Anthony Frazer

Fan

Ziaohong

Wei

Peter Gordon

Peter

Ronald

Yi

Xiaohong

Vincent Paul

Vicki Dawn

Narelle Leigh

Lin

Shuo

Ihsanul

Xiaodong

Hai

Jing Xin

Tebwe

Rachael Leigh

Bing

Peifei
Award

Grad. Dip. in Ec.

Grad. Dip. in App. Ec.

Grad. Dip. in Ec.

Grad. Dip. in Ec.

Grad. Dip. in Ec.

Grad. Dip in Ec.

Grad. Dip. in Ec.

Grad. Dip. in Ec.

Grad. Dip. in Adv. Ec.

Grad. Dip. in Int'1 Ec.

Grad. Dip. in Int'1 Ec.

Grad. Dip. in Ec.

Grad. Dip. in Int'1 Ec.

Grad. Dip. in Int'1 Ec.

Grad. Dip. in Int'1 Ec.

Grad. Dip. in Adv. Ec.

Grad. Cert. in Ec.

Grad. Dip. in Ec.

Grad. Dip. in Int'1 Ec.

Grad. Dip. in Int'1 Ec.

Grad. Dip. in Adv. Ec.

Grad. Dip. in Ec.

Grad. Dip. in Ec.

Grad. Dip. in Int'1 Ec.

Master of App. Ec.(Int'l)

Grad. Dip. in App. Ec.

Grad. Dip. in Int'1 Ec.

Grad. Dip. in Int'1 Ec.

Grad. Dip. in Int'1 Ec.

Grad. Dip. in App. Ec.

Grad. Dip. in Ec.

Grad. Dip. in Ec.

Grad. Dip. in Int'l Ec. 
Table 13: (continued)

$\begin{array}{llll}\text { Year } & \text { Family } & \text { First names } & \text { Award } \\ & \text { name } & & \\ 1998 & \text { Kanchan- } & \text { Anand Bhimsen } & \text { Grad. Dip. in App. Ec. } \\ & \text { athanavibul } & & \\ 1993 & \text { Kelly } & \text { Peter Elliott } & \text { Grad. Dip. in Ec. } \\ 1993 & \text { Konno } & \text { Akira } & \text { Grad. Dip. in Ec. } \\ 2001 & \text { Kulya } & \text { Preechyanud } & \text { Master of App. Ec. } \\ 1992 & \text { Kupke } & \text { Valerie Elizabeth } & \text { Grad. Dip. in Ec. } \\ 1998 & \text { Lao } & \text { To } & \text { Grad. Dip. in Int'1 Ec. } \\ 2001 & \text { Leung } & \text { Wing Yan } & \text { Grad. Cert. in Int'1 Ec. } \\ 1999 & \text { Li } & \text { Fuying } & \text { Grad. Dip. in Int'1 Ec. } \\ 1999 & \text { Li } & \text { Zhentao } & \text { Grad. Dip. in Int'1 Ec. } \\ 1997 & \text { Liu } & \text { Bin } & \text { Grad. Dip. in Int'1 Ec. } \\ 1997 & \text { Liu } & \text { Ping } & \text { Grad. Dip. in Int'1 Ec. } \\ 1998 & \text { Liu } & \text { Fang } & \text { Grad. Dip. in Int'1 Ec. } \\ 1999 & \text { Liu } & \text { Linlin } & \text { Grad. Dip. in Int'1 Ec. } \\ 2000 & \text { Liu } & \text { Wenzhong } & \text { Grad. Dip. in Int'1 Ec. } \\ 1999 & \text { Lu } & \text { Zhouxiang } & \text { Grad. Dip. in Int'1 Ec. } \\ 2000 & \text { Lu } & \text { Xiaoli } & \text { Grad. Dip. in Int'1 Ec. } \\ 1995 & \text { Majba } & \text { Erica Colina } & \text { Grad. Dip. in Ec. } \\ 2001 & \text { Malycha } & \text { Kym Peter } & \text { Grad. Dip. in Adv. Ec. } \\ 1991 & \text { Manson } & \text { Andrew James } & \text { Grad. Dip. in Ec. } \\ 1992 & \text { Melville } & \text { Kevin James } & \text { Grad. Dip. in Ec. } \\ 1992 & \text { Mokgweetsi } & \text { Ross Onalethata } & \text { Grad. Dip. in Ec. } \\ 1998 & \text { Nguyen } & \text { Dac Bang } & \text { Grad. Dip. in App. Ec. } \\ 2001 & \text { Nguyen } & \text { Thi Minh } & \text { Master of App. Ec. } \\ 2000 & \text { Ni } & \text { Jihui } & \text { Grad. Dip. in Int'1 Ec. } \\ 1992 & \text { Nicholls } & \text { Scott James } & \text { Grad. Dip. in Ec. } \\ 1992 & \text { Palmer } & \text { Martin James } & \text { Grad. Dip. in Ec. } \\ 1994 & \text { Parsonage } & \text { Roland Craig } & \text { Grad. Dip. in Ec. } \\ 1999 & \text { Pei } & \text { Zhiyong } & \text { Grad. Dip. in Int'1 Ec. } \\ 1997 & \text { Peng } & \text { Li } & \text { Grad. Dip. in Int'1 Ec. } \\ 1999 & \text { Peng } & \text { Gaojian } & \text { Grad. Dip. in Int'1 Ec. } \\ 1993 & \text { Phillips } & \text { Richard Morley } & \text { Grad. Dip. in Ec. } \\ 1999 & \text { Power } & \text { Mark Raymund } & \text { Grad. Dip. in Ec. } \\ 1997 & \text { Qiu } & \text { Li-Xin } & \text { Grad. Dip. in Int'1 Ec. } \\ 1999 & \text { Reynolds } & \text { Timothy William } & \text { Grad. Dip. in Int'1 Ec. } \\ & & \text { Grad. Cert. in Int'1 Ec. }\end{array}$


Table 13: (continued)

$\begin{array}{lll}\text { Year } & \text { Family } & \text { First names } \\ & \text { name } & \\ 2002 & \text { Riyadi } & \text { Bambang Mukti } \\ 2000 & \text { Roh } & \text { Kyung-Oak } \\ 1992 & \text { Shao } & \text { Quanxi } \\ 1997 & \text { Sun } & \text { Liwei } \\ 1990 & \text { Taylor } & \text { Philip John } \\ 2002 & \text { Truscott } & \text { Glyn } \\ 2000 & \text { Wadey } & \text { Peter John } \\ 1997 & \text { Wang } & \text { Lei } \\ 1998 & \text { Wang } & \text { Xiaodong } \\ 2000 & \text { Wang } & \text { Shiqing } \\ 2000 & \text { Wang } & \text { Xiaoxi } \\ 1990 & \text { Ward } & \text { Steven David } \\ 2002 & \text { Williamson } & \text { Joshua David } \\ 2002 & \text { Wing } & \text { Shan Leung } \\ 2001 & \text { Wing } & \text { Yan Leung } \\ 2000 & \text { Xia } & \text { Bingjun } \\ 1997 & \text { Xu } & \text { Mingde } \\ 1998 & \text { Xu } & \text { Hui Jun } \\ 1999 & \text { Xu } & \text { Ling } \\ 1998 & \text { Yean } & \text { Lei } \\ 1990 & \text { Young } & \text { Douglas Arthur } \\ 2000 & \text { Yu } & \text { Taojin } \\ 2002 & \text { Yu } & \text { Zehong } \\ 1997 & \text { Zhang } & \text { Ling } \\ 1997 & \text { Zhang } & \text { Zhiyong } \\ 1998 & \text { Zhang } & \text { Cuiping } \\ 1998 & \text { Zhang } & \text { Jianhua } \\ 2000 & \text { Zhang } & \text { Jiangbo } \\ 2000 & \text { Zhang } & \text { Liping } \\ 2000 & \text { Zhao } & \text { Qunzi } \\ 1998 & \text { Zheng } & \text { Li } \\ 1999 & \text { Zhu } & \text { Lingyan } \\ 1998 & \text { Zuo } & \text { Chang Sheng }\end{array}$

\section{Award}

Master of App. Ec.

Grad. Cert. in Int'l Ec.

Grad. Dip. in Ec.

Grad. Dip. in Int'1 Ec.

Grad. Dip. in Ec.

Grad. Dip. in Int'l Ec.

Grad. Dip. in App. Ec.

Grad. Dip. in Int'l Ec.

Grad. Dip. in Int'1 Ec.

Grad. Dip. in Int'1 Ec.

Grad. Dip. in Int'1 Ec.

Grad. Dip. in Ec.

Grad. Dip. in Adv.Ec.

Master of App. Ec.(Int'1)

Grad. Cert. in Int'1 Ec.

Grad. Dip. in Int'1 Ec.

Grad. Dip. in Int'l Ec.

Grad. Dip. in Int'l Ec.

Grad. Dip. in Int'l Ec.

Grad. Dip. in Int'l Ec.

Grad. Dip. in Ec.

Grad. Dip. in Int'1 Ec.

Master of App. Ec.(Int'l)

Grad. Dip. in Int'l Ec.

Grad. Dip. in Int'1 Ec.

Grad. Dip. in Int'1 Ec.

Grad. Dip. in Int'l Ec.

Grad. Dip. in Int'1 Ec.

Grad. Dip. in Int'l Ec.

Grad. Dip. in App. Ec.

Grad. Dip. in Int'l Ec.

Grad. Dip. in Int'l Ec.

Grad. Dip. in Int'l Ec. 
Table 14: Rhodes Scholars with a University of Adelaide major in Economics, ${ }^{\text {a }}$ 1938-2003

\begin{tabular}{lll} 
Year & Family name & First names \\
\hline 1938 & Crisp & Leslie Finlay \\
1951 & Opie & Roger Gilbert \\
1959 & Terrell & Richard Deane \\
1973 & Best & Simon Peter Francis \\
1977 & Fraser & Robert Weston \\
1991 & Gibbard & Peter John \\
1993 & Nickless & Samuel Robert \\
1997 & Roediger & Anthony Paul \\
2002 & Allgrove & Benjamin David \\
2003 & Killicoat & Phillip
\end{tabular}

aCrisp completed a B.A. with a major in Economics; Allgrove completed a B.Com. (but won the major prizes for dux of Microeconomics II and Macroeconomics II); and Gibbard, Nickless, Roediger and Allgrove also completed the LL.B. at Adelaide before going on to Oxford. 
Table 15: University awards in economics and commerce, 19012002

\begin{tabular}{llll}
\multicolumn{1}{c}{ Name of award } & Begun & $\begin{array}{l}\text { First } \\
\text { award }\end{array}$ & $\begin{array}{l}\text { Year } \\
\text { with- } \\
\text { drawn }\end{array}$ \\
\hline Bachelor of Arts (with Economics subjects) & 1901 & 1901 & current \\
Bachelor of Laws (with Economics subjects) & 1901 & 1901 & current \\
Advanced Certificate in Commerce & 1902 & 1904 & 1907 \\
Diploma in Commerce & 1907 & 1908 & 1952 \\
Diploma in Economics \& Political Science & 1920 & 1922 & 1930 \\
Bachelor of Economics & 1930 & 1935 & current \\
Bachelor of Economics (Hons) & 1939 & 1945 & current \\
Diploma in Public Administration & 1930 & $193 x$ & 1952 \\
Master of Arts in Economics & $1901 ?$ & 1959 & 1978 \\
Master of Economics & 1938 & 1950 & current \\
Master of Agricultural Science (Economics) & 1963 & 1967 & $1988 ?$ \\
Master of Business Management & 1963 & 1968 & 1986 \\
Doctor of Philosophy & 1965 & 1971 & current \\
Master of Business Administration & 1987 & 1990 & current \\
Graduate Diploma in Economics & 1988 & 1989 & 2001 \\
Bachelor of Commerce & 1991 & 1991 & current \\
Bachelor of Commerce (Hons) & 1992 & 1992 & current \\
Master of Commerce & 1992 & $199 x$ & current \\
Graduate Diploma in Advanced Economics & 1993 & 1994 & current \\
Graduate Certificate in Management & 1995 & 1995 & current \\
Graduate Diploma in Management & 1995 & 1995 & 1998 \\
Bachelor of Finance & 1996 & 1997 & current \\
Graduate Certificate in Economics & 1996 & 1999 & current \\
Graduate Certificate in International Ec. & 1996 & 1997 & current \\
Graduate Diploma in International Economics & 1996 & 1997 & current \\
Graduate Diploma in Applied Economics & 1997 & 1998 & current \\
Master of Economics (coursework) & 1997 & 1997 & current \\
Graduate Diploma in Business Management & 1997 & 1997 & current \\
Bachelor of Finance (Hons) & 1998 & 1999 & current \\
Bachelor of Economics (Int'l Agribusiness) & 1998 & 1999 & current \\
Master of Applied Economics & 2000 & 2000 & current \\
Master of Applied Economics (International) & 2000 & 2000 & current \\
Master of Applied Finance & 2002 & & current
\end{tabular}


Table 16: Undergraduate graduations in Economics and Commerce, by award, 1904-1957

Advanced

Diploma

Certificate Diploma in Bachelor in in Economics \& of

Commerce Commerce Political Science Economics

$1904 \quad 4$

19053

Total

$1906 \quad 6$

$1907 \quad 7$

1908

1909

1910

1912

2

1913

5

1914 
Table 16 (continued)

Advanced

\section{Diploma}

Certificate

in in Bachelor

Economics \& of

Commerce Commerce Political Science Economics Total 1934

1935

22

1936

28

12

1937

36

1938

31

1939

33

1940

18

1941

1942

1943

1944

1945

11

4

7

5

9

1946

1

1947

13

1948

20

1949

41

1950

29

1951

26

1952

26

1953

22

1954

15

1955

19

1956

12

1957

11

2

22

29

214

$3 \quad 39$

$1 \quad 32$

$1 \quad 34$

$0 \quad 18$

$5 \quad 16$

$1 \quad 5$

18

49

110

$0 \quad 1$

$4 \quad 17$

$5 \quad 25$

$10 \quad 51$

$7 \quad 36$

$16 \quad 42$

$5 \quad 31$

$5 \quad 27$

$6 \quad 21$

$13 \quad 32$

$21 \quad 33$

$15 \quad 26$ 
Table 17: Number of new B.Ec., B. Fin., M.Ec. and Ph.D. graduates, by award, 1945-2003

B.Ec. B.Fin.

\begin{tabular}{|c|c|c|c|c|c|c|}
\hline & B.Ec. & (Hons) & B.Fin. (Hons) & M.Ec. & Ph.D. & Total \\
\hline 1945 & 1 & 1 & & & & 2 \\
\hline 1946 & 0 & 0 & & & & 0 \\
\hline 1947 & 4 & 1 & & & & 5 \\
\hline 1948 & 5 & 3 & & & & 8 \\
\hline 1949 & 10 & 3 & & & & 13 \\
\hline 1950 & 7 & 4 & & 1 & & 12 \\
\hline 1951 & 16 & 2 & & 1 & & 19 \\
\hline 1952 & 5 & 2 & & 1 & & 8 \\
\hline 1953 & 5 & 2 & & 1 & & 8 \\
\hline 1954 & 6 & 2 & & 1 & & 9 \\
\hline 1955 & 13 & 2 & & 3 & & 18 \\
\hline 1956 & 21 & 0 & & 1 & & 22 \\
\hline 1957 & 15 & 6 & & 1 & & 22 \\
\hline 1958 & 20 & 5 & & 1 & & 26 \\
\hline 1959 & 16 & 2 & & 1 & & 19 \\
\hline 1960 & 31 & 0 & & 1 & & 32 \\
\hline 1961 & 31 & 4 & & 0 & & 35 \\
\hline 1962 & 33 & 7 & & 1 & & 41 \\
\hline 1963 & 19 & 3 & & 0 & & 22 \\
\hline 1964 & 37 & 5 & & 2 & & 44 \\
\hline 1965 & 29 & 6 & & 0 & & 35 \\
\hline 1966 & 44 & 7 & & 2 & & 53 \\
\hline 1967 & 60 & 6 & & 2 & & 68 \\
\hline 1968 & 47 & 4 & & 3 & & 54 \\
\hline 1969 & 54 & 3 & & 0 & & 57 \\
\hline 1970 & 69 & 10 & & 0 & & 79 \\
\hline 1971 & 69 & 6 & & 1 & 2 & 78 \\
\hline 1972 & 59 & 10 & & 1 & 0 & 70 \\
\hline 1973 & 83 & 14 & & 1 & 2 & 100 \\
\hline 1974 & 98 & 10 & & 3 & 1 & 112 \\
\hline 1975 & 101 & 16 & & 5 & 0 & 122 \\
\hline 1976 & 95 & 17 & & 2 & 0 & 114 \\
\hline 1977 & 119 & 17 & & 1 & 0 & 137 \\
\hline 1978 & 121 & 9 & & 1 & 1 & 132 \\
\hline
\end{tabular}


Table 17 (continued)

B.Ec.

B.Fin.

B.Ec. (Hons.) B.Fin. (Hons.) M.Ec. Ph.D. Total

\begin{tabular}{|c|c|c|c|c|c|c|c|}
\hline 1979 & 125 & 9 & & & 2 & 2 & 138 \\
\hline 1980 & 106 & 10 & & & 1 & 0 & 117 \\
\hline 1981 & 113 & 11 & & & 3 & 1 & 128 \\
\hline 1982 & 145 & 8 & & & 2 & 1 & 156 \\
\hline 1983 & 144 & 4 & & & 3 & 1 & 152 \\
\hline 1984 & 138 & 15 & & & 2 & 2 & 157 \\
\hline 1985 & 168 & 13 & & & 0 & 2 & 183 \\
\hline 1986 & 151 & 26 & & & 2 & 0 & 179 \\
\hline 1987 & 143 & 8 & & & 1 & 2 & 154 \\
\hline 1988 & 180 & 8 & & & 1 & 0 & 189 \\
\hline 1989 & 155 & 11 & & & 0 & 0 & 166 \\
\hline 1990 & 169 & 10 & & & 0 & 1 & 180 \\
\hline 1991 & 223 & 6 & & & 1 & 0 & 230 \\
\hline 1992 & 206 & 8 & & & 2 & 1 & 217 \\
\hline 1993 & 100 & 11 & & & 0 & 0 & 111 \\
\hline 1994 & 82 & 18 & & & 2 & 2 & 104 \\
\hline 1995 & 80 & 10 & & & 0 & 1 & 91 \\
\hline 1996 & 71 & 12 & & & 0 & 5 & 88 \\
\hline 1997 & 119 & 11 & 1 & & 1 & 2 & 134 \\
\hline 1998 & 92 & 17 & 1 & & 4 & 2 & 116 \\
\hline 1999 & 91 & 12 & 21 & 2 & 1 & 2 & 129 \\
\hline 2000 & 123 & 17 & 65 & 3 & 2 & 3 & 213 \\
\hline 2001 & 76 & 14 & 51 & 2 & 4 & 4 & 151 \\
\hline 2002 & 78 & 15 & 63 & 1 & 1 & 2 & 160 \\
\hline 2003 & 74 & 9 & 59 & 0 & 2 & 2 & 146 \\
\hline
\end{tabular}




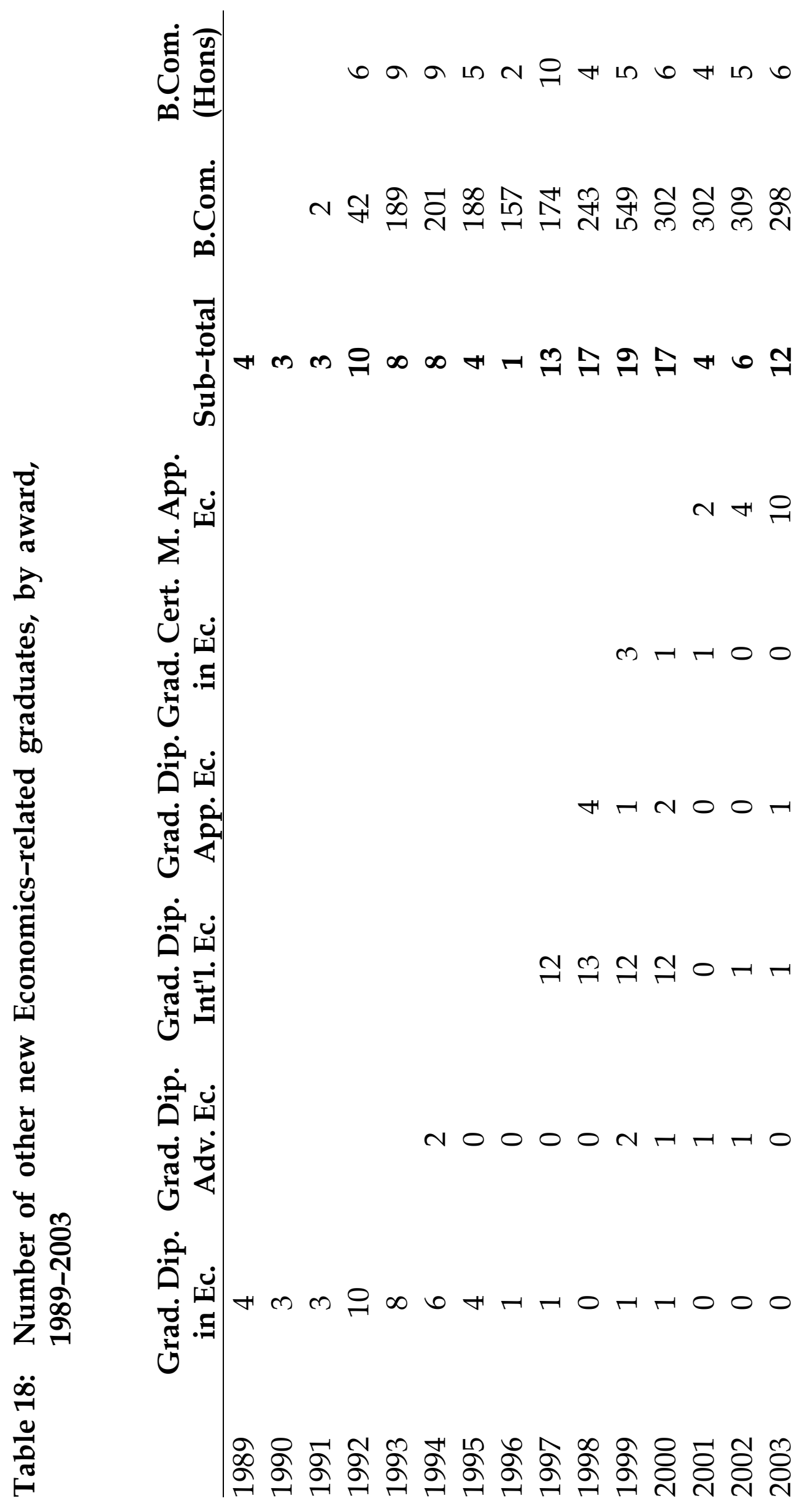


Table 19: South Australian Centre for Economic Studies staff, 1982-2002

(Until February 1993, The Centre for South Australian Economic Studies; jointly owned by the University of Adelaide and Flinders University of South Australia.)

\section{Director}

Norm Thomson 1982-1985

Trevor Mules 1985-1991

Michael O'Neil 2001-present

Executive Director

Cliff Walsh 1992-1998

Professor of Economic Studies

Cliff Walsh 1992-2001

Managing Director

Greg Coombs 1998-2000

Acting Director

Barry Burgan 1991-1992

Deputy Director

Graham Scotta 1982-2000

Director (Projects)

Greg Coombs 1994-1998

Associate/Deputy Director (Projects)

Katrina Ball 1993-1995

Doug Young 1998-1999

Jim Hancock 1999-present

Research Manager

Barry Burgan 1987-1990 
Table 19 (continued)

Executive Assistant

Davina Dolman 1985-present

Senior Economists

Michael O'Neil 1994-2000

Kevin Kirchner 1994-2002

Senior Research Economists

$\begin{array}{lll}\text { Stephen } & \text { McDonald } & \text { 1990-1990 } \\ \text { James } & \text { Giesecke } & 1995-1996 \\ \text { Doug } & \text { Young } & 1996-1997 \\ \text { Jim } & \text { Hancock } & 1998-1999 \\ \text { James } & \text { Weatherford } & 1999-2000 \\ \text { Steve } & \text { Whetton } & \text { 2002-present }\end{array}$

Research Economists

$\begin{array}{lll}\text { Michele } & \text { Jones } & 1987-1989 \\ \text { Janine } & \text { Molloy } & 1987-2002 \\ \text { Stephen } & \text { McDonald } & 1989-1990 \\ \text { Malcolm } & \text { Buckby } & 1990-1993 \\ \text { Elizabeth } & \text { Geddes } & 1991-1994 \\ \text { James } & \text { Giesecke } & 1994-1994 \\ \text { Julie } & \text { Delforce } & 1994-1994 \\ \text { Glyn } & \text { Wittwer } & 1995-1998 \\ \text { Melissa } & \text { Bright } & 1996-2000 \\ \text { Sarah } & \text { Lindsay } & 1997-2000 \\ \text { Rini } & \text { Budiyanti } & 1999-2000 \\ \text { Steve } & \text { Whetton } & 1999-2002 \\ \text { Anthony } & \text { Kosturjak } & 1999-\text { present } \\ \text { Marianne } & \text { Herbert } & \text { 2002-present } \\ \text { Ben } & \text { Dolman } & \text { 2002-present }\end{array}$

a Flinders University staff member 
Table 20: Centre for International Economic Studies staff, 19892003

Executive Director

$\begin{array}{lll}\text { Kym } & \text { Anderson } & \begin{array}{l}\text { 1989-present (on leave } \\ \text { mid-1990-1992) } \\ \text { mid-1990-1991 }\end{array} \\ \text { Ian } & \text { McLean } & \text { 1992 } \\ \text { Richard } & \text { Pomfret } & \end{array}$

Deputy Director

Randy Stringer 1996-2002

Executive Assistant

$\begin{array}{lll}\text { Zoe } & \text { Ratcliffe } & 1996-1999 \\ \text { Jane } & \text { Russell } & 1999-2001 \\ \text { Wendy } & \text { Zweck } & 2001-2003\end{array}$

Post-Doctoral Research Fellows

$\begin{array}{lll}\text { Julie } & \text { Delforce } & 1995 \\ \text { Zhaoyang } & \text { Peng (joint with CERC) } & 1996-1997 \\ \text { Anna } & \text { Strutt } & 1999 \\ \text { Martina } & \text { Brockmeier } & 1999 \\ \text { Chunlai } & \text { Chen } & 2000-2001 \\ \text { Shunli } & \text { Yao } & 2000-2001 \\ \text { Glyn } & \text { Wittwer } & 2001 \\ \text { Lee Ann } & \text { Jackson } & \text { 2002-present }\end{array}$

Senior Affiliates (external and Adjunct Professors)

$\begin{array}{lll}\text { Richard } & \text { Blackhurst } & \text { 2002-present } \\ \text { Max } & \text { Corden } & \text { 2001-present } \\ \text { Christopher } & \text { Findlay } & \text { 2000-present } \\ \text { Joseph } & \text { Francois } & \text { 1997-present } \\ \text { David } & \text { Greenaway } & \text { 2002-present } \\ \text { Václav } & \text { Klaus } & \text { 2001-present } \\ \text { Peter } & \text { Lloyd } & \text { 2002-present } \\ \text { Keith } & \text { Maskus } & \text { 2000-present } \\ \text { Ross } & \text { Milbourne } & \text { 1997-2000 } \\ \text { Mike } & \text { Moore } & \text { 2001-present } \\ \text { Bob } & \text { Nobay } & \text { 2001-present } \\ \text { Phil } & \text { Pardey } & \text { 2002-present } \\ \text { Perry } & \text { Shapiro } & \text { 1999-present } \\ \text { Andrew } & \text { Stoler } & \text { 2002-present }\end{array}$


Table 20 (continued)

Senior Affiliates (external and Adjunct Professors)

Cliff

Walsh

Alan

Winters

2001-present

2002-present

Affiliates (external)

Malcolm Bosworth 2002-present

Jane Drake-Brockman 2002-present

Walter Goode 2002-present

Chantal Nielsen 2002-present

Peter Robinson 2002-present

Randy Stringer 2002-present

Anna Strutt 2002-present

Brett Williams 2002-present

Glyn Wittwer 2002-present

Associates (internal: School of Economics staff)

Louise

Brian

Richard

Allsopp

Bentick

Christopher Findlay

Per

Fredriksson

Noel

Gaston

Derek

Healey

Lee Ann

Jackson

Cornelis

Los

Ian

McLean

D.T. (Tin) Nguyen

Jonathan Pincus

Richard Pomfret

Ramkishen Rajan

Sue Richardson

Colin

David

Peter

Rod
Rogers

Round

Summers

Tyers 1999-present

1989-present

2001-present

1989-1999

1995-1999

1990-1998

1989-1990

2002-present

1999-1999

1989-present

1990-present

1991-present

1992-present

1999-present

1989-present

1989-present

1989-2001

1993-1996

1989-1990 
Table 21: Chinese Economies Research Centre staff, 1990-1999

(Formerly the China Economic Research Unit (1990-1995); merged into the Centre for International Economic Studies in 2000)

Co-Directors

Andrew Watson

1990-1999

Christopher Findlay

1990-1999

Executive Assistant

Jan Holmes

1990-1999

Post-Doctoral Research Fellows

Harry X. Wu 1992-1995

Enjiang Cheng 1994-1996

Zhaoyang Peng (joint with CIES) 1996-1997

Chunlai Chen 1999 
Table 22: The Joseph Fisher Lectures and lecturers, 1904-2003

Year Lecture title Lecturer

1904 Commercial Education

Henry G. Turner

1906 Commercial Character

Lewis A. Jessop

1908 The Influence of Commerce on

J. Currie Elles

Civilization

1910 Banking as a Factor in the Development of J. Russell French Trade and Commerce

1912 Australian Company Law, and Some Sidelights on Modern Commerce

1914 Problems of Transportation, and Their

David J. Gordon

Relation to Australian Trade and Commerce

1917 War Finance: Loans, Paper Money and Taxation

1919 The Humanizing of Commerce and Industry

1921 Currency and Prices in Australia

Henry Y. Braddon

1923 Money, Credit and Exchange

Robert F. Irvine

1925 The Guilds

Gerald Mussen

1927 The Financial and Economic Position of Australia

1929 Public Finance in Relation to Commerce

Douglas B. Copland

J. Russell Butchart

Henry Y. Braddon

1930 Current Problems in International Finance

1932 Australia's Share in International Recovery

Stanley M. Bruce

1934 Gold Standard or Goods Standard

Richard C. Mills

1936 Some Economic Effects of the Australian Tariff

1938 Australian Economic Progress Against a World Background

1940 Economic Co-ordination

Theodore Gregory

Alfred C. Davidson

Leslie G. Melville

Lyndhurst F. Giblin

Colin Clark

Roland Wilson 
Table 22 (continued)

1942 The Australian Economy During War Robert G. Menzies

1944 Problems of a High Employment Economy Herbert Cole Coombs

1946 Necessary Principles for Satisfactory

S.M. Wadham Agricultural Development in Australia

1948 The Importance of the Iron and Steel Industry to Australia

1950 The Economic Consequences of Scientific Research

1952 Australian Agricultural Policy

John G. Crawford

1954 The Economics of Federal-State Finance Wilfred Prest

1956 Japan and the General Agreement on Tariffs and Trade

1958 National Superannuation: Means Test or Contributions?

1960 Mass Entertainment: The Origins of a Modern Industry

James E. Meade

Richard I. Downing

Asa Briggs

1962 Industrial Research and Economic Growth Bruce R. Williams in Australia

1964 Australian Foreign Aid Policy

Heinz W. Arndt

1967 Australian Tariff Policy

W. Max Corden

1969 Balancing External Payments by Adjusting E.H. Phelps Brown Domestic Income

1971 Income Inflation in Australia

Ronald F.

Henderson

1974 Political Economy and the Problems of Our Time: In Defence of General Economics

1976 A Comparison of the Approach of the Industries Assistance Commission and of John Vaizey the Jackson Committee to Industrial Development

\section{G. Alf Rattigan}


Table 22: (continued)

1978 Australian Economics, 1967 to 1977

Fred H. Gruen

1981 Work and Welfare in the Years Ahead

1985 Japan Faces Affluence

Robert G. Gregory

Martin

Bronfenbrenner

1986 What Do We Really Know About Monetary Policy?

1988 Pacific Challenges to the United States

David Laidler

1993 How Convincing is the Evidence Linking Education and Income?

Paul Krugman

Orley Ashenfelter

1994 The NAFTA Debate and American Trade

Anne O. Krueger Policy

1995 Protection and Liberalization in Australia

W. Max Corden and Abroad

1996 Population, Food and Trade

D. Gale Johnson

1997 Strengthening Intellectual Property Rights Keith E. Maskus in Asia: Implications for Australia

1999 Human Behaviour and the Transmission

Mark Gersovitz of Infectious Disease: An Economist's Perspective

2001 Public Policy and Higher Education

2002 Natural Resources in Economic

Peter H. Karmel Development

2003 Globalization

Ed Barbier

Mike Moore 
Table 23: Deans, Assistants and Librarians of the Faculty and Schools of Economics, Commerce and Graduate Business, 1946-2002

SchoolDepartment of Economics

Dean/Head/Chairman

$\begin{array}{lll}\text { Brian } & \text { Tew } & 1946-1949 \\ \text { Peter } & \text { Karmel } & 1950-1961 \\ \text { Harold } & \text { Lydall } & 1962-1967 \\ \text { Eric } & \text { Russell } & 1967-1976 \\ \text { Ron } & \text { Hirst } & 1976-1977 \\ \text { Robert } & \text { Lindner } & 1978 \\ \text { Geoff } & \text { Harcourt } & 1978-1979 \\ \text { Frank } & \text { Jarrett } & 1979-1980 \\ \text { Cliff } & \text { Walsh } & 1980-1981 \\ \text { John } & \text { Hatch } & 1981-1984 \\ \text { Cliff } & \text { Walsh } & 1984-1985 \\ \text { Margaret } & \text { Meyler } & 1986-1987 \\ \text { John } & \text { Hatch } & 1988-1989 \\ \text { Tom } & \text { Sheridan } & 1990 \\ \text { Jonathan } & \text { Pincus } & 1991-1996 \\ \text { Richard } & \text { Pomfret } & 1997-1999 \\ \text { Colin } & \text { Rogers } & 2000-\text { present }\end{array}$

School Executive Officer

$\begin{array}{lll}\text { Elizabeth } & \text { Geddes } & \text { 1996-2000 } \\ \text { Silvia } & \text { Schwarz } & \text { 2001-present }\end{array}$

Departmental Secretary

Natalie Scott-Thompson 1952-1954

Coralie Clark (now Pridmore) 1960-1963

Gill Morgan 1968-1972

Bernice Edwards 1979-1980

Julia Gregory 1981-1985

Kerry Braini 1986-2000

Administrative Assistant

Helen Wickens 1963-1996

Marlene Mott 1990-1995 
Table 23 (continued)

Librarian for Economics and Commerce

(Based at the Napier Birks Room Library)

Kath

Cheshire

1968-1985

Pauline

Clarke

1985-1992

(Based at the Barr Smith Library)

Teresa Kow

1977-1984

Les

Howard

1984-present

SchoolDepartment of Commerce

Dean/Head/Chairman

Russell Mathews 1953-1964

Ken Wright 1965-1971

G.B. Mitchell 1972-1974

Ken Wright 1975-1977

Fred Bloch 1978-1979

Scott Henderson 1980-1989

Bernie Mills 1989-1993

Fred Bloch 1994-present

School Executive Officer

Lynette Swift 1996-present

Departmental Secretary

Cheryl Hensel 1978-1980

Lucy Hatch 1980-1991

Lee Jones 1991-1995

Paula Hollamby 1996 
Table 23 (continued)

Adelaide Graduate School of Business

Dean

Bob

Fred

Newman

1984-1987 (acting)

Helen

McDougall

1987-1997

Tony

Thorne

1997-2001

Travaglione

2002-present

School Manager

Leah

Hill

2002-present

Executive Officer

Carol

McHugh

1992-present

Program Manager

Helenmary McMeekan

1999-2001

Jade

O'Donohue

2002-present

School Secretary

Trish

Lyndon

1990-1993

Anna

Stretton

1993-1995

Leah

Hill

1995-1998

Helenmary

McMeekan

1998-1999

Jade

O'Donohue

2000-2001 
Table 23 (continued)

Faculty of Economics

Dean

$\begin{array}{lll}\text { Peter } & \text { Karmel } & \text { 1952-1962 } \\ \text { Harold } & \text { Lydall } & \text { 1962-1966 } \\ \text { Eric } & \text { Russell } & 1967-1969 \\ \text { Ken } & \text { Wright } & 1969 \\ \text { Frank } & \text { Jarrett } & 1970-1971 \\ \text { Ken } & \text { Wright } & 1972-1973 \\ \text { Bob } & \text { Newman } & 1974-1975 \\ \text { Frank } & \text { Jarrett } & 1976-1977 \\ \text { Derek } & \text { Healey } & 1978-1979 \\ \text { Scott } & \text { Henderson } & 1980-1981 \\ \text { Frank } & \text { Jarrett } & 1982-1984 \\ \text { Norm } & \text { Thomson } & 1985-1987 \\ \text { Frank } & \text { Jarrett } & 1987-1988\end{array}$

Faculty of Economics and Commerce

Dean

Norm Thomson 1989-1991

Scott Henderson 1992-1993

Sue Richardson 1994

Margaret Meyler 1995-1996

Faculty of Performing Arts, Law, Architecture, Commerce and Economics (PALACE)

Executive Dean

$\begin{array}{lll}\text { Margaret } & \text { Meyler } & 1997 \\ \text { Judith } & \text { Brine } & 1998-2000 \\ \text { Malcolm } & \text { Gilles } & \text { 2000-2001 }\end{array}$

Faculty of the Professions

Executive Dean

Fred

McDougall

2002-present 
Table 24: Number of Lecturers E, D and B-E in Australian teaching Departments of Economics with more than two Professors, 1987 and 2002*

\begin{tabular}{|c|c|c|c|c|c|c|}
\hline & $\begin{array}{c}\text { No. of } \\
\text { Lecturers } \\
\text { E,1987 }\end{array}$ & $\begin{array}{c}\text { No. of } \\
\text { Lecturers } \\
\text { E, } 2002\end{array}$ & $\begin{array}{l}\text { No. of } \\
\text { Lecturers } \\
\text { D, } 2002\end{array}$ & $\begin{array}{l}\text { No. of } \\
\text { Lecturers } \\
\text { B-E, } 2002\end{array}$ & $\begin{array}{l}\% \text { of } \\
\text { Es on } \\
\text { the } \\
\text { staff, } \\
2002\end{array}$ & $\begin{array}{c}\% \text { of } \\
E+D s \\
\text { on the } \\
\text { staff, } \\
2002\end{array}$ \\
\hline Melbourne & 10 & 16 & 10 & 61 & 26 & 43 \\
\hline Macquarieb & 3 & 7 & 4 & 37 & 19 & 30 \\
\hline Monash ${ }^{b}$ & 5 & 7 & 9 & 45 & 16 & 36 \\
\hline Sydney & 6 & 7 & 14 & 50 & 14 & 42 \\
\hline Uni NSW & 6 & 6 & 13 & 40 & 15 & 48 \\
\hline UNE & 6 & 6 & 7 & 24 & 25 & 54 \\
\hline U Qld & 2 & 5 & 12 & 38 & 13 & 45 \\
\hline ANUa,b & 3 & 5 & 5 & 33 & 15 & 30 \\
\hline UTSa & na & 4 & 6 & 34 & 12 & 29 \\
\hline UWA $^{c}$ & 5 & 4 & 2 & 23 & 17 & 26 \\
\hline Adelaide & $3^{d}$ & 3 & 4 & 21 & 14 & 33 \\
\hline AVERAGE & 4.8 & 6.4 & 7.8 & 37 & 17 & 38 \\
\hline
\end{tabular}

* The 1987 numbers are from Jarrett et al. (1987); the 2002 numbers are calculated from current websites of the relevant departments

a Includes Finance

b Includes Econometrics/Statistics

c Includes Agricultural Economics

d 1985, after which Harcourt left for Cambridge, followed by Walsh to the ANU in 1987 and Jarrett to retirement in 1988 
Table 25: Average completion times for Ph.D. and Masters theses, 1948-2002

$\begin{array}{lccc}\begin{array}{l}\text { Ph.D. students } \\ \text { Students } \\ \text { enrolled } \\ \text { between: }\end{array} & \begin{array}{c}\text { Number of } \\ \text { graduating } \\ \text { students* }\end{array} & \begin{array}{c}\text { Average } \\ \text { completion } \\ \text { time }\end{array} & \begin{array}{c}\text { Median } \\ \text { completion } \\ \text { time }\end{array} \\ \text { 1965-1969 } & 7 & 86 & 79 \\ 1970-1979 & 6 & 59 & 54 \\ 1980-1989 & 6 & 44 & 45 \\ 1990-1999 & 19 & 45 & 42 \\ 2000-2002 & 6 & 40 & 36\end{array}$

Masters students

$\begin{array}{lccc}\begin{array}{l}\text { Students } \\ \text { enrolled } \\ \text { between: }\end{array} & \begin{array}{c}\text { Number of } \\ \text { graduating } \\ \text { students* }\end{array} & \begin{array}{c}\text { Average } \\ \text { completion } \\ \text { time (months) }\end{array} & \begin{array}{c}\text { Median } \\ \text { completion } \\ \text { time (months) }\end{array} \\ \text { 1948-1959 } & 9 & 38 & 28 \\ 1960-1969 & 11 & 58 & 45 \\ 1970-1979 & 19 & 50 & 50 \\ 1980-1989 & 3 & 32 & 30 \\ 1990-1999 & 10 & 33 & 30\end{array}$

*Only those students whose exact completion times are known were counted 
Table 26: School/Department of Economics working papers, 1970 to $2002^{1}$

\section{(a) Working Papers}

01-10Anderson, K.H. and R. Pomfret, "Relative Standards in New Market Economies: Evidence from Central Asian Household Surveys", October 2001.

01-9 Barreto, R.A. and K. Kobayashi, "Open Economy Schumpeterian Growth", September 2001.

01-8 Mitchener, K.J. and I. W. Mclean, "The Productivity of U.S. States since 1880", July 2001.

01-7 Whitley, J. "The Political Economy of Quality Measurement: A Case Study of the U.S. Slaughter Cattle Market", June 2001.

01-6 Lott, J.R. Jr. and J. Whitley, "Safe Storage Gun Laws: Accidental Deaths, Suicides, and Crime", June 2001.

01-5 Lott, J.R. Jr. and J. Whitley, "Abortion and Crime: Unwanted Children and Out-of-Wedlock Births", May 2001.

01-4 Rogers, C. and T.K. Rymes, "Indirect Convertibility and Quasi-futures Contracts: Two Non-operational Schemes for Automatic Stabilisation of the Price Level?" February 2001.

01-3 Barreto, R.A. and J. Alm, "Corruption, Optimal Taxation and Growth", January 2001.

01-2 Barreto, R.A. "Endogenous Corruption, Inequality and Growth: Econometric Evidence", January 2001.

01-1 Rogers, C. "Krugman on Japan's Liquidity Trap", January 2001.

00-9 Pomfret, R. "Regional Trade Arrangements and Economies in Transition", December 2000.

00-8 Anderson, K.H. and R. Pomfret, "Gender Effects of Transition: The Kyrgyz Republic", November 2000.

00-7 Los, C.A. "Visualization of Chaos for Finance Majors", November 2000.

${ }^{1}$ No working papers were produced in 1997 or 2001. 


\section{Table 26 (continued)}

00-6 Karuppiah, J. and C.A. Los, "Wavelet Multi-resolution Analysis of High-Frequency FX Rates, Summer 1997", September 2000.

00-5 Barnes, M.L. and P.J.F. de Lima, "Modeling Financial Volatility: Extreme Observations, Nonlinearities and Nonstationarities", September 2000.

00-4 Barnes, M.L., "Threshold Relationships among Inflation, Financial Market Development and Growth", September 2000.

00-3 Pomfret, R., "State-directed Diffusion of Technology: the Mechanization of Cotton-harvesting in Soviet Central Asia", September 2000.

00-2 Rymes T.K. and Rogers, C., "On 'Money' in ISLM and AD/AS Models", August 2000.

00-1 Hughes, A.W., "Testing for Non-normality in the Presence of One-Sided Slope Parameters", April 2000,

99-9 Gaffney, J. and Rogers, C. "Some Properties of a Small Open Economy, December 1999.

99-8 Williams, J. and R.C. Sickles, "Turning from Crime: A Dynamic Perspective", November 1999.

99-7 Hughes, A.W. "Hypothesis Testing in the Presence of Onesided Nuisance Parameters", September 1999.

99-6 Dao, T. "Flows and Economic Growth in a Small Open Economy", August 1999.

99-5 Williams, J. "Getting Tough On Crime: Will It Win The War?" August 1999.

99-4 Damania, R. "Regulation and Monitoring with Corrupt Bureaucrats", August 1999.

99-3 Anderson, K.H. and R. Pomfret, "Living Standards During Transition to a Market Economy: The Kyrgyz Republic in 1993 and 1996", April 1999.

99-2 Williams, J. "Substitutes or Complements? Alcohol, Cannibis and Tobacco", April 1999.

99-1 Hughes, A.W., M.L. King and K.K. Teng, "Selecting the Order of an ARCH Model", January 1999.

98-18Richardson, S. "Households, Individuals and Low Wages", December 1998. 


\section{Table 26 (continued)}

98-17Rogers, C. and T. Rymes, "Indirect Convertibility and QuasiFutures Contracts: Two Non-Operational Schemes For Automatic Stabilisation The Price Level?" November 1998.

98-16Pomfret, R. "Agrarian Reform in Uzbekistan: Why has the Chinese Model Failed to Deliver?" October 1998.

98-15Pincus, J.J. "Is the Treasury Subsidising Australian Undergraduates? Or, Investing in Higher Education?" September 1998.

98-14Williams, J. "Property Crime: Just a Risky Occupation? Exploring the Issue with a Birth Cohort", September 1998.

98-13Hughes, A.W. "Variable Selection in the Linear Regression Model with One-Sided Information and a Small Sample", September 1998.

98-12Barnes, M.L. "On the Nature of Dependence in the Volatility of US Stock Returns", August 1998.

98-11Barnes, M.L. "Nonlinear Threshold Relationships Between Inflation and Nominal Returns: A Time Series Approach to 39 Different Countries", August 1998.

98-10Barnes, M.L. "Aggregation of Short-Memory Processes, The Volatility of Stock Market Return Indices and Long Memory", August 1998.

98-9 Damania R. "Why the Weak Win: The Strategic Role of Investment in Lobbying", August 1998.

98-8 Damania, R. "The Impact of a Goods and Services Tax on Product Market Competition", August 1998.

98-7 Damania, R. "The Scope for Exchange Rate Pass-Through in an Oligopoly", August 1998.

98-6 Brennan, G. and J.J. Pincus, "Is Vertical Fiscal Imbalance so Inefficient? Or: The Flypaper Effect is Not an Anolmaly", July 1998.

98-5 Pomfret, R. and K.H. Anderson, "Poverty in the Kyrgyz Republic", June 1998.

98-4 Mitchener, K.J. and I.W. McLean, "U.S. Regional Growth and Convergence, 1880-1980", May 1998.

98-3 Williams, J. and R.C. Sickle, "An Intertemporal Model of Rational Criminal Choice", January 1998. 


\section{Table 26 (continued)}

98-2 Williams, J. and R.C. Sickles, "On The Role of Social Capital in Youth Crime: A Dynamic Structural Approach", January 1998.

98-1 Williams, J. and R.C. Sickles, "The Fable of Crime as Work", January 1998.

96-1 Tisato, P. and N. Porter, "Pollution Control and Cost Minimising Firm Responses."

95-2 Richardson, S. "Education and Social Justice."

95-1 Brennan, G. and J.J. Pincus, "A Minimalist Model of Federal Grants and Flypaper Effects."

94-2 Pincus, J.J. “James Buchanan's Federalist Papers."

94-1 Neal, P. "Credit Rationing and Uncertainty: Complementarity in Post Keynesian and New Keynesian Monetary Economics?"

93-2 Abdoerrahman, A.J. Fisher and C.M. Boast, "The Use of Animal Manure on Crops on Lombok Island, Indonesia."

93-1 Abdoerrahman, C.M. Boast, A.J. Fisher, M.Gibbs and B. Glaetzer, "Crop Selection on Lombok Island, Indonesia."

92-4 McLean, I.W. and S.J. Woodland, "Consumer Prices in Australia."

92-3 Neal, P. "The Determination of Exchange Rates and the Effectiveness of Monetary Policy In Financial Markets."

92-2 Travers, P. and S. Richardson, "Living Decently."

92-1 Nguyen, D.T. "The Goods and Services Tax, Intertemporal Choice and Domestic Saving: A Theoretical Analysis."

91-9 Pincus, J.J. "The Australian Constitution: What Should Economists Do?"

91-8 McLean, I.W. and S.J. Woodland, "Trends in the Composition of Consumer Expenditure: Australia 1854-1913."

91-7 McLean, I.W. "Saving in Settler Economies: Australian and American Comparisons."

91-6 Travers, P. and S. Richardson, "Proxy Indicators and the Real World."

91-5 Tisato, P. "The Impact of A Cost Minimisation User Cost Model on Public transport Subsidy."

91-4 Hefford, R.K. "Lucky Country or Fools' Paradise?"

91-3 Eichengreen, B. and I.W. McLean, “The Supply of Gold Under the Pre-1914 Gold Standard." 


\section{Table 26 (continued)}

91-2 Fischer, A.J., J.P.A. Burns, M.J. Meyler, P. Tiernan and J.H. Hatch, "The Market for Taxi-cab Licences: An Experimental Analysis."

91-1 Richardson, S. "Cash Income and Full Income: Does the Difference Matter?"

90-7 Lovell, K., S. Richardson, P. Travers and L. Wood, "Resources and Functionings: A New View of Inequality in Australia."

90-6 Healey, D. "Emergence of Japan as a Capital Exporter."

90-5 Healey, D. “Taiwan's Economic Future: Some Points from a 1990 Vantage Point."

90-4 Travers, P. and S. Richardson, "Measuring the Standard of Living."

90-3 Healey, D. "Australian Economic Relations with Korea and Taiwan: Reflections on the Garnaut Report."

90-2 Gibbard, P. and R. Tyers, "The Distributional Incidence of Commodity Price Stabilisation in an Open Economy."

90-1 Thomson, N.J. "Fiscal Equalisation: Horizontal Balance, Efficiency and the Commonwealth Grants Commission."

89-12Healey, D. and B. McFarlane, "Colin Clark Reminisces: An Unscripted Discussion With Bruce McFarlane and Derek Healey."

89-11Healey, D. "Australia's Interest and Role in Enhanced Asia/Pacific Economic Cooperation."

89-10Healey, D. "The Underlying Conditions for the Successful Generation of EPZ-Local Linkages: The Experience of the Republic of Korea."

89-9 Tyers, R. and P. Phillips, "ASEAN in Pacific Basin Trade: Export Composition and Performance 1970-1986."

89-8 Fischer, A. "The Size of a Swing to Unseat a Government: A Cautionary Note."

89-7 Fischer, A. "On Even Numbers of Seats in Parliament."

89-6 Richardson, S. and P. Travers, "The Conceptual Flaws in Poverty Lines."

89-5 Richardson, S. and P. Travers, "Averages and Tails: The Tenuous Link Between Poverty Status and the Standard of Living." 


\section{Table 26 (continued)}

89-4 Gunasekera, D. and R. Tyers, "Imperfect Competition and Returns to Scale in a Newly Industrialising Economy: A General Equilibrium Analysis of Korean Trade Policy."

89-3 Ng, S.N. and R. Tyers, "A 'Booming Sector' Approach to Labour Policy in Singapore."

89-2 Nguyen, D.T. and Y.C. Chiang, "Exchange Rate Determination: The Case of Singapore."

89-1 Nguyen, D.T. and Y.C. Chiang, "Covered Interest Rate Parity in the Singapore Market."

88-10Anderson, K. "Rent Seeking and Price Distortion Policies In Rich and Poor Countries."

88-9 Anderson, K. and Y-I. Park, "The Rise and Demise of Clothing in Economic Development: The Case of Japan."

88-8 Anderson, K. and R. Tyers, "Agricultural Protection Growth in Advanced and Newly Industrialised Countries."

88-7 Anderson, K. "Does Agricultural Growth in Poor Countries Harm Agricultural-Exporting Rich Countries?"

88-6 Anderson, K. and Y-I. Park, "China and The International Relocation of World Textiles and Clothing Activity."

88-5 McLean, I.W. "Growth In a Small Open Economy: A Historical View."

88-4 McLean, I.W."The Distributional Impact of The Depression In the United States."

88-3 Tyers, R. and K. Anderson, "Price Elasticities in International Food Trade: Synthetic Estimates from a Global Model."

88-2 Tyers, R. "Developing Country Interests in Agricultural Reform."

88-1 Healey, D.T. "Australian/Japanese Economic Interactions: Some Policy Issues."

87-10Grossman, P.J. "Government and Growth: Cross-Sectional Evidence."

87-9 McLean, I.W. “Unequal Sacrifice: Distributional Aspects of Depression and Recovery in Australia."

87-8 Richardson, S. "Who Benefits from Higher Education?"

87-7 Grossman, P.J. Federalism and the Size of Government." 


\section{Table 26 (continued)}

87-6 Grossman, P.J. "A Political Theory of Intergovernmental Grants."

87-5 McNabb, R. and S. Richardson, "The Relationship Between Earnings, and Education and Experience: Evidence for Australia."

87-4 Walsh, C. “The Distribution of Taxing Powers Between Levels of Government: The Possibility of State Income Taxation Reconsidered."

87-3 Richardson, S. and P. Travers, "The Poverty of Poverty Lines."

87-2 Anderson, K., M. Britten-Jones and R.S. Nettle, "Two Corrections to the Standard Theory of Distortions and Welfare."

87-1 Tee, C.T. and A.J. Fischer, "Income Stabilisation by Borrowing and Lending: The Case of a Finite Time Horizon."

86-8 Thomson, N.J. " Issues in Local Government Rating."

86-7 Thomson, N.J. "Apportioning Revenue Sharing Grants Between the States: The Commonwealth Grants Commission Reports of 1981,1982 and 1985."

86-6 Healey, D.T. “Countertrade: A Selected Bibliography."

86-5 Healey, D.T. “Countertrade: Solution or Problem?"

86-4 Anderson, K. "Agricultural Policies of Industrial Countries and Their Effects Traditional Food Exporters."

86-3 Anderson, K. and R. Tyers, "Economic Growth and Market Liberalisation In China: Implications for Agricultural Trade."

86-2 Kolf, P. "The Demand for Electricity and Interfuel Substitution in South Australia, 1959/60-1982/83."

86-1 Sheridan, T. "Planners and the Australian Labour Market, 1945-49."

85-5 Anderson, K. and P.G. Warr, "Distributional Effects of Agricultural Price Distortions: A General Equilibrium Analysis for Korea."

85-4 Davis, K. “Australian Monetary Policy, Recent Experience and Some Current Issues."

85-3 Kwee, P.O.B. “The Cyclically Adjusted Budget Deficit in Australia: A Critique of the Literature and Some Current Issues." 


\section{Table 26 (continued)}

85-2 McLean, I.W. and S. Richardson, "More or Less Equal? Australian Income Distribution Since 1933."

85-1 Burns, M.E. and C. Walsh, "Public Goods with Price Exclusion: Market Segmentation and Allocative Efficiency."

84-10Wolfson, M. "A Theorem on the Existence of Zones of Initiation and Deterence Intriligator-Brito Arms Race Models."

84-9 Wolfson, M. "Notes on Economic Warfare."

84-8 McLean, I.W. "Economic Wellbeing: Living Standards and Inequality Since 1900."

84-7 Thomson, N.J. "Federal Equalisation Funding of Schools in Australia."

84-6 Rushdi, A.A. "Demand for Energy in the Commercial Sector of South Australia."

84-5 Rushdi, A.A. " A Forecast of Capital Requirements in the Electricity Supply Industry of South Australia."

84-4 Burns, M.E. and C. Walsh, "Pricing, Profitability and Efficiency in the provision of Excludable Public Goods: A Demand Distribution Approach."

84-3 Findlay, C. "The Persistence and the Pervasiveness of the Regulation of International Trade in Civil Aviation Services."

84-2 Campbell, H.F. and R.K Lindner, " Mineral Exploration and the Neutrality of Rent Royalties."

84-1 Walsh, C. "On the Political Economy of Capital Gains Tax Reform."

83-5 Chapman, B. "Clarifying the Quit-Wage Nexus."

83-4 Chapman, B. " Does the Size of the Budget Deficit Matter?"

83-3 Chapman, B. "Testing Issues of Labour Turnover."

83-2 Chapman, B. "A Profile of the Australian Labour Market."

83-1 Healey, D.T. "Aid and Development Aid with Special Reference to Australian Aid."

82-6 Campbell, H.F. and R.K. Lindner," The Effect of the Resource Rent Tax on Mineral Exploration."

82-5 Harcourt, G.C. “The 1982 G.L Wood Memorial LectureReflections on the Development of Economics as a Discipline." 


\section{Table 26 (continued)}

82-4 Harcourt, G.C. "A Man for All Systems - Talking with Kenneth Boulding."

82-3 Harrison, A. and B. Hart, "A Labour-Market Model of Unemployment Insurance."

82-2 Pardey, P., R. Lindner and F.G. Jarrett, "Distance to Information Source and the Time-Lag to Early Adoption of Trace Element Fertilisers."

82-1 Burbidge, J. and A. Harrison, "Testing for the Effects of Oil Price Rises Using Vector Autoregressions."

81-17Lindner, R.K. and A.J. Fischer, "Risk Aversion, Information Quality and the innovation Adoption Time-Lag."

81-16Thomson, N.J. "Administering Local Government Equalisation: The Grants Commission and Revenue Raising Capacity."

81-15Thomson, N.J. “Taxation Issues in Australia: Some Current Issues."

81-14Chapman, B.J. and N.J. Thomson, "School and Tertiary Student Participation and the Level of Family Income."

81-13Burns, P. "Buyer Behaviour in a Multi Object Sequential Auction."

81-12Davis, K. "The Australian Financial System- Directions fro Reform."

81-11Davis, K. "Economies Of Scale in the Payments Mechanism."

81-10Davis, K. "Reserve Requirement Changes as a Monetary Instrument."

81-9 McDougall, F.M. and D.K. Round, "Diversification in Large Manufacturing Firms in South Australia."

81-8 Healey, D.T. "The Indonesian Economy: An Early 1981 Perspective."

81-7 Stutchbury, M. "Government Intervention and Industry Restructuring."

81-6 Stutchbury, M. "Reinterpreting the Playford Legend: The Industrialisation of South Australia, 1938-65."

81-5 Healey, D.T. "Structural Change and Structural Adjustment In Japan." 


\section{Table 26 (continued)}

81-4 Harcourt, G.C. "Critiques and Alternatives: Reflections on Some Recent (And Not So Recent) Controversies."

81-3 Harcourt, G.C. "Notes on an Economic Querist: G.L.S Shackle."

81-2 Harcourt, G.C. "An Early Post-Keynesian: Lorie Tarshis (or: Tarshis on Tarshis by Harcourt.)"

81-1 Starkie, D.N.M. "Economic Efficiency and Road Expenditures: The case of Rural Arterials."

80-10Thomson, N.J. "Cross Subsidisation of Rural Areas Via Utility Pricing Policies."

80-9 Gaffney, J.M. and G.R Anstis, "Functional Forms for Lorenz Curves."

80-8 Walsh, C. "Excludable Public Goods: On their Nature and Significance."

80-7 Brennan, G. and C. Walsh, "A Problem In the Interpretation of the Contractarian Position: The Impossibility of a Paretian Paretian."

80-6 Ian W. McLean, I.M. "Risk and Crop-mix Choice in Kansas, 1874-1914."

80-5 Brennan, G., D. Lee and C. Walsh, "Uniform All-or-None Pricing of Public Goods."

80-4 Healey, D.T. "Structural Adjustment within the Economies of Australia, Japan, Sweden and the United States in Response to Imports from Developing Countries, Lessons for Australia."

80-3 Harcourt, G.C. "Marshall, Sraffa and Keynes: Incompatible Bedfellows?"

80-2 Piggott, J. "Measuring the Social Desirability of Tax Changes."

80-1 Harcourt, G.C. "The Sraffian Contribution: An Evaluation."

79-7 Sheridan, T. "Oppositions, Factions and Candidates in A.E.U. Elections In Australia 1907-72."

79-6 Round, D. “A Simultaneous Equation Model of Profitability and Tariffs in Australian Manufacturing Industries."

79-5 Bentick, B.L. "Capitalized Property Taxes and the Viability Of Rural Enterprise Subject to Urban Pressure."

79-4 McLean, I.W. "The Analysis of Agricultural Productivity: Alternative Views and Victorian Evidence." 


\section{Table 26 (continued)}

79-3 Davis, K.T. and M.K. Lewis, "Inflation First: An Evaluation of Recent Economic Policies."

79-2 Zabalza, A., J. Piggott and J. Lambe, "The 'Demand-Pull' and 'Cost Push' Hypotheses: An Analytical Comparison."

79-1 Harcourt, G.C. "Joan Robinson: Portrait of a Lady."

\section{(b) Economics Department Papers}

11 Alauddin, M., "Employment and Output Response in an Input-output Framework: The Case of Bangladesh 1972-73 and 1977-78," November 1981.

10 McLean, I.W., S.F. Molloy and P. Lockett, "Australian Rural Employment and Labour Input," April 1981.

9 Fischer, A.J., " A Bias in the Voting System for the Australian Senate."

8 Hefford, R., "Britain and the common agricultural policy".

7 Fischer, A.J., "The Random Sampling of Votes in the Australian Senate," January 1978.

5 Lindner, R.K., "Autonomy and Accountability in Planning Research: The Challenge for Research Management," September 1976.

4 Lindner, R.K. and J.L. Byrne, "Profitability of Investment in Abattoir Slaughtering Facilities," February 1974.

3 Mules, T.J., "Supply and Cost Equations for Australian Agriculture with Applications to Income Determination," July 1973.

2 Thomson, N.J., "Death Duties and the South Australian Woolgrower," July 1971.

1 Hefford, R.K., "The Diary Industry: Pricing Arrangements and Production Controls," November 1970. 
Table 27: South Australian Centre for Economic Studies working papers and monographs, 1982-2002

(a) SACES Occasional Paper series

27 Arnold, A., R. Lamacraft, and M. Gibbs, 'Adoption of Advanced Manufacturing Technologies by South Australian Manufacturers: Are Investment Justification Methodologies a Barrier?' June 1992.

26 Mules, T. and M. Buckby, 'Economic Performance of Australian States, 1978 to 1989', June 1991.

25 Neal, P., 'A Study of the Economic Impact of the HomeStart Loan Scheme', April 1991.

24 Taylor, P., 'An Analysis of the Impact of a Major Horticultural Development on the Economy of the South East of South Australia', January 1991.

23 Gibbs, M. and N.J. Thomson, 'The Impact of Proposed Rent Increases on Leasehold Pastoral Properties in South Australia', May 1989.

22 McDonald, S., 'Connection Policies for Reticulated Energy Provision in South Australia', March 1989.

21 Crowley, J., C. Findlay and M. Gibbs, 'Vertical Integration in the Export of Perishable Primary Produce from South Australia', April 1989.

20 Jones, M., 'The Economic Significance of Tourism Expenditure in South Australia for 1985/86', November 1988.

19 Burgan, B., M. Crosby and T. Mules, 'Impact of Gas Use in Power Generation on the South Australian Economy', December 1987.

18 Scott, G.McL., 'The May Economic Decisions', 1987.

17 Edwards, P.C.R. and N.J. Thomson, 'Economic Activity Regeneration Through Heritage (The 'EARTH' Scheme)', October 1986.

16 Thomson, N.J., 'Fiscal Incentives for the Conservation of Privately Owned Heritage Buildings', August 1986.

15 Arnold, A. and T. Mules, 'The Economic Impact of Irrigated Agriculture in South Australia', October 1985.

14 Thomson, N.J., 'The Economics of Native Vegetation Retention on Private Land', January 1985. 


\section{Table 27 (continued)}

13 Thomson, N.J., 'The Economic Case for Increased Funds for Australia's Roads', January 1985.

12 Rushdi, A.A., 'Forecasts of Demand for Electricity in South Australia', June 1984.

11 Fedorovich, T. and T. Mules, 'Estimating the Effect on Premiums of Some Possible Changes to the South Australian Workers Compensation Act 1971', June 1984.

10 Rushdi, A.A., 'Impact of Price, Output and Technology on the Industrial Demand for Electricity in South Australia', April 1984.

9 Lee, J.Y.C., 'Microprocessor Technology - A Study of Its Impact, Potential and Implications in South Australia', March 1984.

8 Rehn, M., 'CAD/CAM Technology for South Australia - The Bottom Line', 1984.

7 Ryland, G.J., 'A Project to Develop A Computerized Model of S.A. Dryland Farming as a Management Tool', December 1983.

6 Kain, P.G., 'Government and Urban Transport: The Adelaide Experience', July 1983.

5 Bierbaum, C.B., 'Regional Industries Growth and Structural Change', July 1983.

4 Crowle, C.T., 'Lessons from South Australian Public Service Pay Rates', June 1983.

3 Bierbaum, C.B., 'Structural Change: The South Australian Experience', December 1982.

2 Thomson, N.J. 'Fiscal Horizontal Equalization and Local Government', November 1982.

1 Elliott, P.J., Bancorp Holdings Limited and F.M. McDougall, 'The South Australian Capital Market: A Study of a Regional Capital Market', August 1982.

\section{(b) SACES Economic Briefings}

Two to four issues have been published for corporate clients each year since 1983 (Volumes 1-20). 


\section{Table 27 (continued)}

\section{(c) SACES Economics Issues papers}

4 Covick, O., 'The 2002-03 Commonwealth Budget', August 2002.

3 O'Neil, M. and S. Whetton, 'An Assessment of the Impact of Gaming Machines on Small Regional Economies' May 2002.

2 Symon, A., 'Timor Sea Natural Gas Development: Still in Embryo', August 2001.

1 Hancock, J., 'The 2001-02 South Australian Budget', August 2001.

\section{(d) SACES monographs}

Covick, O. (ed.) (2002), Policies to Boost Australian Savings: How? and Why? Adelaide: Wakefield Press for the South Australian Centre for Economic Studies.

Coombs, G. (ed.) (2001), Essays on Regional Economic Development, Adelaide: Wakefield Press for the South Australian Centre for Economic Studies.

Hancock, J. and J. Smith (2001), Financing the Federation, Adelaide: South Australian Centre for Economic Studies.

Coombs, G. and S. Lindsay (1998), The Economic Impact of Climate Change Policy on South Australia, Adelaide: South Australian Centre for Economic Studies.

Mules, T.J. (ed.) (1989), South Australian Manufacturing in Transition, Adelaide: Wakefield Press for the Centre for South Australian Economic Studies.

Burns, J.P.A., J.H. Hatch and T.J. Mules (eds.) (1986), The Adelaide Grand Prix: The Impact of a Special Event, Adelaide: Centre for South Australian Economic Studies.

Healey, D.T., F.G. Jarrett and J.M. McKay (eds.) (1985), The Economics of Bushfires: The South Australian Experience, Melbourne: Oxford University Press for the Centre for South Australian Economic Studies. 
Table 28: Centre for International Economic Studies working papers and monographs, 1989-2002

\section{(a) CIES Discussion Papers}

0236 Damania, R., "Protectionist Lobbying and Strategic Investment", November 2002.

0235 Damania, R. and J. Hatch, "Protecting Eden: Markets or Government?" November 2002.

0234 Anderson, K., "Agricultural Trade Reform and Poverty Reduction in Developing Countries", November 2002.

0233 Wood, D. and K. Anderson, "What Determines the Future Value of an Icon Wine? Evidence from Australia", November 2002.

0232 Anderson, K. and C. Nielsen, "Economic Effects of Agricultural Biotechnology Research in the Presence of Pricedistorting Policies". November 2002.

0231 Jackson, L.A., "Who Benefits from Quality Labelling? Segregation Costs, International Trade and Producer Outcomes", November 2002.

0230 Rajan, R., "Trade Liberalization and Poverty: Where Do We Stand?" November 2002.

0229 Rajaguru, G. and R. Siregar, "Sources of Variations Between the Inflation Rates of Korea, Thailand and Indonesia During the Post-1997 Crisis", November 2002.

0228 Barbier, E.B., “Water and Economic Growth”, October 2002.

0227 Barbier, E.B., "The Role of Natural Resources in Economic Development", October 2002. (The 49 th $^{\text {th }}$ Joseph Fisher Lecture.)

0226 Rajan, R. and R. Sen, "Liberalisation of Financial Services in Southeast Asia under the ASEAN Framework Agreement on Services (AFAS)", October 2002.

0225 Anderson, K., "Building an Internationally Competitive Australian Olive Industry: Lessons from the Wine Industry," October 2002.

0224 Bentzen, J., S. Leth-Sørensen and V. Smith, "Prices of French Icon Wines and the Business Cycle: Empirical Evidence from Danish Wine Auctions," September 2002. 


\section{Table 28 (continued)}

0223 Bentzen, J. and V. Smith, "Wine Prices in the Nordic Countries: Are They Lower Than in the Region of Origin?" September 2002.

0222 Rajan, R. and G. Bird, "“Will Asian Economies Gain from Liberalizing Trade in Services?" September 2002.

0221 Siregar, R.Y. and G. Rajaguru, "Base Money and Exchange Rate: Sources of Inflation in Indonesia during the Post-1997 Financial Crisis", August 2002.

0220 Rajan, R., "International Financial Liberalisation in Developing Countries: Lessons from Recent Experiences", July 2002.

0219 Rajan, R., R. Siregar and G. Bird, "Capital Flows and Regional Financial Interdependencies in the Context of Crises: Evidence From East Asia", August 2002.

0218 Bird, G. and R. Rajan, "The Political Economy of A TradeFirst Approach to Regionalism", July 2002.

0217 Rajan, R. and R. Sen, “Liberalisation of International Trade in Financial Services in Southeast Asia: Indonesia, Malaysia, Philippines and Thailand", July 2002.

0216 Anderson, K., "International Trade and Industry Policies", July 2002.

0215 Anderson, K., "The New Global Economy: Opportunities and Challenges for Small Open Economies", July 2002.

0214 Pincus, J.J., "Environmental Economics and the MurrayDarling", July 2002.

0213 Brennan, G. and J.J. Pincus, "From the Australian Settlement to Microeconomic Reform: the Change in Twentieth Century Policy Regimes", July 2002.

0212 Teuku R., G. Rajaguru and R.Y. Siregar, "Exchange Rate Volatility, Trade and 'Fixing for Life' in Thailand", June 2002.

0211 Anderson, K., J. Huang and E. Ianchovichina, "Impact of China's WTO Accession on Farm-Nonfarm Income Inequality and Rural Poverty", November 2002. 


\section{Table 28 (continued)}

0210 Bird, G. and R. Rajan, "Too Much of a Good Thing? The Adequacy of International Reserves in the Aftermath of Crises", April 2002.

0209 Anderson, K., "Measuring Effects of Trade Policy Distortions: How Far Have We Come?" April 2002.

0208 Rajan, R. and R. Sen, "The Japan-Singapore "New Age" Economic Partnership Agreement: Background", March 2002.

0207 Anderson, K., "Pecularities of Retaliation in WTO Disputes Settlement", March 2002.

0206 Jackson, L.A., "Is Regulatory Harmonization Efficient? The Case of Agricultural Biotechnology Labelling", March 2002.

0205 Siregar, R. and R.S. Rajan, "Impact of Exchange Rate Volatility on Indonesia's Trade Performance in the 1990s", March 2002.

0204 Zhao, X., K. Anderson and G. Wittwer, "Who Gains from Australian Generic Wine R \& D and Promotion?" February 2002.

0203 Bird, G. and R. Rajan, "The Evolving Asian Financial Architecture", January 2002.

0202 Rajan, R. and R. Sen, “Singapore's New Commercial Trade Strategy: the Pros and Cons of Bilateralism", January 2002.

0201 Rajan, R., "Safeguarding Against Capital Account Crises: Unilateral, Regional and Multilateral Options for East Asia", January 2002.

0150 Rajan, R., "Economic Globalization and Asia: Trade, Finance and Taxation", December 2001.

0149 Rajan, R. and I. Sugema, "The Devaluation of the Thai Baht and a Simple Second Generation Currency Crisis Model", December 2001.

0148 Rajan, R., "International Financial Flows and Regional Financial Safeguards in East Asia", December 2001. 


\section{Table 28 (continued)}

0147 Rajan, R. and R. Sen, "Trade Reforms in India Ten Years On: How Has it Fared Compared to its East Asian Neighbours?" December 2001.

0146 Evenett, S. J., "Do all Networks Facilitate International Commerce? The Case of US Law Firms and the Mergers and Acquisition Wave of the Late 1990s", December 2001.

0145 Anderson, K. and S. Yao, "How Can South Asia and SubSaharan Africa Gain from the Next WTO Round?" November 2001.

0144 Bernauer, T. and E. Meins, "Scientific Revolution Meets Policy and the Market: Explaining Cross-National Differences in Agricultural Biotechnology Regulation", November 2001.

0143 Anderson, K., D. Norman and G. Wittwer, "Globalization in the World's Wine Markets", November 2001.

0142 Busse, M., "Do Labour Standards Affect Comparative Advantage? Evidence for Labour-Intensive Goods", November 2001.

0141 Stringer, R. and G. Wittwer, "Grapes, Wine and Water: Modelling Water Policy Reforms in Australia", November 2001.

0140 Damania, R., R. Stringer, K.A. Karanth and B. Stith, "The Economics of Protecting Tiger Populations: Linking Household Behaviour to Poaching and Prey Depletion", November 2001.

0139 Damania, R. and E.H. Bulte, "The Economics of Captive Breeding and Endangered Species Conservation", October 2001.

0138 James, J.S and J.M. Alston, "Taxes and Quality: A MarketLevel Analysis", May 2001.

0137 Rajan, R.S., "Choosing an Appropriate Exchange Rate Regime for Small and Open Economies", October 2001.

0136 Anderson, K., B. Dimaranan, J. Francois, T. Hertel, B. Hoekman and W. Martin, "The Burden of Rich and Poor Country Protectionism on Developing Countries", September 2001. 


\section{Table 28 (continued)}

0135 Rajan, R.S. and C.H. Shen, "Are Crisis-Induced Devaluations Contractionary?" September 2001.

0134 Shapiro, P. and J. Petchey, "Internationally Mobile Factors of Production and Economic Policy in an Integrated Regional Union of States", August 2001.

0133 Rajan, R.S. and G. Bird, "Still the Weakest Link: the Domestic Financial System and Post-Crisis Recovery in East Asia", July 2001.

0132 Rajan, R.S. and G. Bird, "Banks, Maturity Mismatches and Liquidity Crises: A Simple Model", July 2001.

0131 Montreevat, S. and R.S. Rajan, "Banking Crisis, Restructuring and Liberalization in Emerging Economies: An Analytic Case Study of Thailand", June 2001.

0130 Francois, J.F., "Factor Mobility, Economic Integration and the Location of Industry", June 2001.

0129 Francois, J.F., "Flexible Estimation and Inference Within General Equilibrium Systems", June 2001.

0128 Rajan, R.S., "Revisiting the Case for a Tobin Tax Post Asian Crisis: a Financial Safeguard or Financial Bonanza?" June 2001.

0127 Bird, G. and R.S. Rajan, "Regional Arrangements for Providing Liquidity in a Financial Crisis: Developments in Asia", June 2001.

0126 Anderson, K. and S. Yao, "China, GMOs, and World Trade in Agricultural and Textile Products", June 2001.

0125 Anderson, K., "The Globalization (and Regionalization) of Wine", June 2001.

0124 Rajan, R.S., "On the Road to Recovery? International Capital Flows and Domestic Financial Reforms in East Asia", May 2001.

0123 Chunlai, C. and C. Findlay, "Patterns of Domestic Grain Flows and Regional Comparative Advantage in Grain Production in China", April 2001.

0122 Rajan, R.S., R. Sen and R. Siregar, "Singapore and the New Regionalism: Trade Relations with Japan and the US", May 2001. 


\section{Table 28 (continued)}

0121 Anderson, K., G. Wittwer and N. Berger, "A Model of the World Wine Market", May 2001.

0120 Barnes, M. and S. Ma, "Market Efficiency or Not? The Behaviour of China's Stock Prices in Response to the Announcement of Bonus Issues", April 2001.

0119 Ma, S. and M. Barnes, "Are China's Stock Markets Really Weak-form Efficient?" April 2001.

0118 Stringer, R., "How Important are the 'Non-Traditional' Economic Roles of Agriculture in Development?" April 2001.

0117 Bird, G. and R.S. Rajan, "Economic Globalization: How Far and How Much Further?" April 2001.

0116 Damania, R., "Environmental Controls with Corrupt Bureaucrats", April 2001.

0115 Whitley, J., "The Gains and Losses from Agricultural Concentration", April 2001.

0114 Damania, R. and E. Barbier, "Lobbying, Trade and Renewable Resource Harvesting", April 2001.

0113 Anderson, K., "Economy-wide Dimensions of Trade Policy and Reform", April 2001.

0112 Tyers, R. and Y. Yang, "European Unemployment and the Asian Emergence: Insights from the Elemental Trade Model", March 2001.

0111 Harris, R.G., "The New Economy and the Exchange Rate Regime", March 2001.

0110 Harris, R.G., "Is there a Case for Exchange Rate Induced Productivity Changes?" March 2001.

0109 Harris, R.G., "The New Economy, Globalization and Regional Trade Agreements", March 2001.

0108 Rajan, R.S., "Economic Globalization and Asia: Trade, Finance and Taxation", March 2001.

0107 Chang, C.L.L. and R.S. Rajan, "The Economics and Politics of Monetary Regionalism in Asia", March 2001.

0106 Pomfret, R., "Reintegration of Formerly Centrally Planned Economies into the Global Trading System", February 2001.

0105 Manzano, G., "Is there any Value-added in the ASEAN Surveillance Process?" February 2001. 


\section{Table 28 (continued)}

0104 Anderson, K., "Globalization, WTO and ASEAN", February 2001.

0103 Schamel, G. and K. Anderson, "Wine Quality and Regional Reputation: Hedonic Prices for Australia and New Zealand", January 2001.

0102 Wittwer, G., N. Berger and K. Anderson, "Modelling the World Wine Market to 2005: Impacts of Structural and Policy Changes", January 2001.

0101 Anderson, K., "Where in the World is the Wine Industry Going?" January 2001.

0050 Allsopp, L., "A Model to Explain the Duration of a Currency Crisis", December 2000.

0049 Anderson, K., "Australia in the International Economy", December 2000.

0048 Allsopp, L., "Common Knowledge and the Value of Defending a Fixed Exchange Rate", December 2000.

0047 Damania, R., P.G. Fredriksson and J.A. List, "Trade Liberalization, Corruption and Environmental Policy Formation: Theory and Evidence", December 2000.

0046 Damania, R., "Trade and the Political Economy of Renewable Resource Management", November 2000.

0045 Rajan, R.S., R. Sen and R. Siregar, "Misalignment of the Baht, Trade Imbalances and the Crisis in Thailand", November 2000.

0044 Rajan, R.S., and G. Bird, "Financial Crises and the Composition of International Capital Flows: Does FDI Guarantee Stability?" November 2000.

0043 Bird, G. and R.S. Rajan, "Recovery or Recession? PostDevaluation Output Performance: The Thai Experience", November 2000.

0042 Rajan, R.S. and R. Sen, "Hong Kong, Singapore and the East Asian Crisis: How Important were Trade Spillovers?", November 2000.

$0041 \mathrm{Li}$ Lin, C. and R.S. Rajan, "Regional Versus Multilateral Solutions to Transboundary Environmental Problems: Insights from the Southeast Asian Haze", October 2000. 


\section{Table 28 (continued)}

0040 Rajan, R.S., "Are Multinational Sales to Affiliates in High Tax Countries Overpriced? A Simple Illustration", October 2000.

0039 Rajan, R.S. and R. Siregar, "Private Capital Flows in East Asia: Boom, Bust and Beyond", September 2000.

0038 Yao, S., "US Permanent Normal Trade Relations with China: What is at Stake? A Global CGE Analysis", September 2000.

0037 Yao, S., "US Trade Sanctions and Global Outsourcing to China", September 2000.

0036 Barnes, M.L., "Threshold Relationships among Inflation, Financial Market Development and Growth", August 2000.

0035 Anderson, K., C.P. Nielsen and S. Robinson, "Estimating the Economic Effects of GMOs: the Importance of Policy Choices and Preferences", August 2000.

0034 Anderson, K. and C.P. Nielsen, "GMOs, Food Safety and the Environment: What Role for Trade Policy and the WTO?" August 2000.

0033 Nguyen, T., "Foreign Exchange Market Efficiency, Speculators, Arbitrageurs and International Capital Flows", July 2000.

0032 Nielsen, C.P. and K. Anderson, "Global Market Effects of Alternative European Responses to GMOs", July 2000.

0031 Rajan, R.S. and R. Siregar, "The Vanishing Intermediate Regime and the Tale of Two Cities: Hong Kong versus Singapore", July 2000.

0030 Rajan, R.S., "(Ir)relevance of Currency Crisis Theory to the Devaluation and Collapse of the Thai Baht", July 2000.

0029 Wittwer, G. and K. Anderson, "Accounting for Growth in the Australian Wine Industry, 1987 to 2003", July 2000.

0028 Rajan, R.S, "Currency Basket Regimes for Southeast Asia: the Worst System with the Exception of All Others", June 2000.

0027 Jones, R.W. and H. Kierzkowski, "Horizontal Aspects of Vertical Fragmentation", June 2000.

0026 Alston, J.M., J.W Freebairn, and J.James, "Beggar-thyNeighbour Advertising: Theory and Application to Generic Commodity Promotion Programs", May 2000.

0025 Anderson, K., "The Anatomy of Australia's Wine Boom: Lessons for Other Industries", May 2000. 


\section{Table 28 (continued)}

0024 Farrell, R., "Research Issues in Japanese Foreign Direct Investment", May 2000.

0023 Peng, C.Y., "Integrating Local, Regional and Global Assessment in China's Air Pollution Control Policy", May 2000.

0022 Maskus, K.E., "Intellectual Property Rights and Foreign Direct Investment", May 2000.

0021 Nielsen, C. and K. Anderson, "GMOs, Trade Policy, and Welfare in Rich and Poor Countries", May 2000.

0020 Lall, S., "FDI and Development: Research Issues in The Emerging Context", May 2000.

0019 Markusen, J.R., "Foreign Direct Investment and Trade", May 2000.

0018 Kokko, A., "FDI and the Structure of Home Country Production", April 2000.

0017 Damania, R., and P.G. Fredriksson, "Collective Action and Protection", March 2000.

0016 Hertel, T.W., K. Anderson, J.F. Francois, and W. Martin, "Agriculture and Non-agricultural Liberalization in the Millennium Round", March 2000.

0015 Dean, J.M, "Does Trade Liberalization Harm the Environment? - a New Test", March 2000.

0014 Bird, G. and R. S. Rajan, "Restraining International Capital Flows: What Does it Mean?" March 2000.

0013 Schamel, G. and H. de Gorter, "More on the Welfare Effects of Distortions via Environmental and Trade Policy", March 2000.

0012 Bird, G. and R.S. Rajan, "Resolving the Interest Rate PremForthcoming inium Puzzle: Capital Inflows and Bank Intermediation in Emerging Economies", March 2000.

0011 Stringer, R., "Food Security in Developing Countries", March 2000.

0010 Stringer, R. and K. Anderson, "Environmental and HealthRelated Standards Influencing Agriculture in Australia", March 2000.

0009 Schamel, G., "Individual and Collective Reputation Indicators of Wine Quality", March 2000. 


\section{Table 28 (continued)}

0008 Anderson, K., "Invigorating the Asian-Pacific Food Economy: APEC's Role", February 2000.

0007 Francois, J.F. and W. Martin, "Commercial Policy Variability, Bindings, and Market Access", February 2000.

0006 Francois, J.F. and L.Schuknecht, "International Trade in Financial Services, Competition, and Growth Performance", February 2000. 0005 James, S., "An Economic Analysis of Food Safety Issues Following the SPS Agreement: Lessons from the Hormones Dispute", February 2000.

0004 Francois, J. and I. Wooton, "Trade in International Transport Services: the Role of Competition", February 2000.

0003 Francois, J., and I. Wooton, "Market Structure, Trade Liberalisation and the GATS", February 2000.

0002 Rajan, R.S., "Examining a Case for an Asian Monetary Fund", January 2000.

0001 Mataloni Jr, R.J., "A Method for Improved Comparisons of US Multinational Companies' Manufacturing Production Abroad", January 2000.

99/29 Rajan, R.S., "Financial and Macroeconomic Cooperation in ASEAN: Issues and Policy Initiatives", December 1999.

99/28 Anderson, K., "Agriculture, Developing Countries, and the WTO Millennium Round", December 1999.

99/27 Rajan, R.S., "Fragile Banks, Government Bailouts and the Collapse of the Thai Baht", November 1999.

99/26 Strutt, A. and K. Anderson, "Estimating Environmental Effects of Trade Agreements with Global CGE Models: a GTAP Application to Indonesia", November 1999.

99/25 Rajan, R.S. and I. Sugema, "Capital Flows, Credit Transmission and the Currency Crisis in Southeast Asia", November 1999.

99/24 Anderson, K., "Australia's Grape and Wine Industry into the 21st Century", November 1999.

99/23 Asher, M.G. and R.S. Rajan, "Globalization and Tax Structures: Implications for Developing Countries with Particular Reference to Southeast Asia", October 1999. 


\section{Table 28 (continued)}

99/22 Rajan, R.S. and I. Sugema, "Government Bailouts and Monetary Disequilibrium: Common Fundamentals in the Mexican and East Asian Crises", October 1999.

99/21 Maskus, K.E. and Y. Chen, "Vertical Price Control and Parallel Imports", October 1999.

99/20 Rajan, R.S., "Not Fixed, Not Floating: What About Optimal Basket Pegs for Southeast Asia?" September 1999.

99/19 Findlay, C. and T. Warren, "Trade in Services: Measuring Impediments and Providing a Framework for Liberalisation", September 1999.

99/18 Martin, W. and D. Mitra, "Productivity Growth and Convergence in Agriculture and Manufacturing", September 1999.

99/17 Francois, J.F., "Investor Confidence and Trade Policy Transparency: Dynamic Implications of an Effective Trade Policy Review Mechanism", August 1999.

99/16 Bird, G. and R.S. Rajan, "Banks, Finanical Liberalization and Financial Crises in Emerging Markets", August 1999.

99/15 Irwin, G. and D. Vines, "A Krugman-Dooley-Sachs Third Generation Model of the Asian Finanical Crisis", August 1999.

99/14 Anderson, K., B. Hoekman and Anna Strutt, "Agriculture and the WTO: Next Steps", August 1999.

99/13 Bird, G. and R.S. Rajan, "Cashing in On and Coping with Capital Volatility", August 1999.

99/12 Rajan, R.S., "Banks, Financial Liberalization and the 'Interest Rate Premium Puzzle' in East Asia", August 1999.

99/11 Bird, G. and R.S. Rajan, "Would International Currency Taxation Help Stabilise Exchange Rates in Developing Countries?" July 1999.

99/10 Spahni, P., "World Wine Developments in the 1990s: An Update on Trade Consequences", June 1999.

99/09 Alston, J.M. and J.A. Chalfant, "Advertising and Consumer Welfare", June 1999. 


\section{Table 28 (continued)}

99/08 Wittwer, G. and K. Anderson, "Impact of the GST and Wine Tax Reform on Australia's Wine Industry: a CGE Analysis", May 1999.

99/07 Pomfret, R., "Transition and Democracy in Mongolia", April 1999.

99/06 James, S. and K. Anderson, "Managing Health Risk in a Market-Liberalizing Environment: An Economic Approach", March 199.9

99/05 Soonthonsiripong, N., "Are Build-Transfer-Operate Regimes Justified?" March 1999.

99/04 Soonthonsiripong, N., "Factors Affecting the Installation of New Fixed Telephone Lines in Provincial Areas in Thailand", March 1999.

99/03 Berger, N. and K. Anderson, "Consumer and Import Taxes in the World Wine Market: Australia in International Perspective", February 1999.

99/02 Hoekman, B. and K. Anderson, "Developing Country Agriculture and the New Trade Agenda", January 1999.

99/01 Anderson, K., "Globalization, WTO and Development Strategies for Poorer Countries", January 1999.

98/09 Marko, M., "An Evaluation of the Basic Telecommunications Services Agreement", December 1998.

98/08 Anderson, K., "Domestic Agricultural Policy Objectives and Trade Liberalization: Synergies and Trade-offs", October 1998.

98/07 Findlay, C., P. Hooper and T. Warren, "Resistances to and Options for Reform in International Air Transport", September 1998.

98/06 Pomfret, R., "Enlargement to Include Formerly Centrally Planned Economies: ASEAN and the EU Compared", May 1998.

98/05 Kokko, A., "Managing the Transition to Free Trade: Vietnamese Trade Policy for the 21st Century", May 1998.

98/04 Anderson, K., "Agricultural Trade Reforms, Research Incentives and the Environment", April 1998. 


\section{Table 28 (continued)}

98/03 Anderson, K., "Agriculture and the WTO into the 21st Century", March 1998.

98/02 Stringer, R., "Environmental Policy and Australia's Horticulture Sector", March 1998.

98/01 Anderson, K., "The Future of the WTO", February 1998.

97/13 Bora, B., "Potential for Investment Liberalization between AFTA and CER", November 1997.

97/12 Findlay, C. and T. Warren, "Potential for Services Liberalisation Between AFTA and CER", November 1997.

97/11 van Beers, C., "Labour Standards and Trade Flows of OECD Countries", October 1997.

97/10 Maskus, K.E., "Implications of Regional and Multilateral Agreements for Intellectual Property Rights", October 1997.

97/09 Maskus, K.E. and G. Yang, "Intellectual Property Rights, Foreign Direct Investment, and Competition Issues in Developing Countries", August 1997.

97/08 Bora, B. and E.M. Graham, "Can APEC Deliver on Investment?" June 1997.

97/07 Bentick, B., "Rethinking HECS: Its Definition and Fiscal Role", June 1997.

97/06 Anderson, K., "The Changing International Context of Australian Aid", June 1997.

97/05 Miller, P. and J. Pincus, "Funding of Higher Education in Australia: Performance and Diversity", May 1997.

97/04 Bora, B. and M.K. Lewis, "The Australian Financial System: Evolution, Regulation and Globalisation", April 1997.

97/03 Stringer, R. and K. Anderson, "International Developments and Sustainable Agriculture in Australia", February 1997.

97/02 Stringer, R., "The Environment, Economics and Water Policies", January 1997.

97/01 Bora, B., "Policy Implications of Canada's Trade and Investment, Linkages with the Asia Pacific", January 1997.

96/14 Anderson, K., "China's Accession to the WTO: Why, How, and When?" November 1996.

96/13 Anderson, K. and C.Y. Peng, "Feeding and Fueling China in the 21st Century", November 1996, revised July 1998. 


\section{Table 28 (continued)}

96/12 Komiya, R., "APEC as Seen From the Eyes of a Japanese Economist", November 1996.

96/11 Stringer, R., "Food Security and Sustainable Development in Asia", November 1996.

96/10 Anderson, K., "Regional and Global Economic Integration: Strategic Issues Affecting Europe and East Asia", August 1996.

96/09 Anderson, K., "Environmental Standards and International Trade", July 1996.

96/08 Panagariya, A., "APEC and the United States", July 1996.

96/07 Pangestu, M., "APEC Leadership in Liberalization: An Untested Experiment", July 1996.

96/06 Greenaway, D., "Current Issues in Trade Policy and the Pacific Rim", July 1996.

96/05 Anderson, K., "Agricultural Policy Reform Under the Uruguay Round: Impact on Asian-Pacific Developing Countries", July 1996.

96/04 Bora, B., "Investment Linkages Between the Asia Pacific and the South Pacific", June 1996

96/03 Anderson, K. and J. Delforce, "Mining Booms Without Income Growth? The Case of Papua New Guinea", April 1996.

96/02 Pomfret, R.d, "Regionalism in Asia and its Impact on China", April 1996.

96/01 Pangestu, M. and B.Bora, "Evolution of Liberalisation Policies Affecting Investment Flows in the Asia Pacific", January 1996.

95/12 Bora, B., "The Asia Pacific Economics Cooperation Process", December 1995.

95/11 Corden, W.M., "Protection and Liberalization in Australia and Abroad", December 1995.

95/10 Bora, B., "Maximising the South Pacific Forum's Benefits from APEC", November 1995.

95/09 Pomfret, R., "APEC and the Lessons of Asian Growth", November 1995.

95/08 Anderson, K., "The Multilateral Trading System and Sustainable Development", October 1995. 


\section{Table 28 (continued)}

95/07 Anderson, K. and A. Strutt, "Agriculture and Sustainable Development in the Reforming Indonesian Economy: A CGE Approach", September 1995.

95/06 Anderson, K., "Social Policy Dimensions of Economic Integration: Environmental and Labour Standards", July 1995.

95/05 Anderson, K., "On Measuring the Extent of Agricultural Policy Intervention: A Review of the PSE and Related Indicators", July 1995.

95/04 Anderson, K., "The GATT's Review of Australia's Trade Policy", March 1995.

95/03 Bora, B., "The Implications of Globalisation for Australian Foreign Investment Policy", March 1995.

95/02 Pomfret, R., "ASEAN: Always at the Crossroads?" March 1995.

95/01 Bora, B. and E. Graham, "Nonbinding Investment Principles in APEC", January 1995.

94/24 Findlay, C., "Trade in Services in the Uruguay Round", December 1994.

94/23 Drake-Brockman, J. and K. Anderson, "The TradeEnvironment Debate and its Implications for Asia-Pacific", November 1994.

94/ 22 Krueger, A.O., "The Role of the NAFTA Debate in U.S. Trade Policy", The 1994 Joseph Fisher Lecture, October 1994.

94/21 Anderson, K. and J. Drake-Brockman, "Globalisation, Trade Policy and the Environment", October 1994.

94/20 Anderson, K., "World Trade Developments from an East Asian Perspective", September 1994.

94/19 Pomfret, R., "Regional Economic Cooperation in Northeast Asia: The Tumen River Project", September 1994.

94/18 Anderson, K., "Impact of Multilateral, Regional and Unilateral Trade Reforms on Agricultural Competitiveness", August 1994.

94/17 Anderson, K., "Distortions to Agricultural Incentives in East Asia: A Survey", August 1994. 


\section{Table 28 (continued)}

94/16 Pomfret, R., "Mongolia's Economic Reforms: Background Content and Prospects", June 1994.

94/15 Samuel, M., C. Findlay and P. Forsyth, "International Aviation Problems and Responses: An Asian Pacific Perspective", June 1994.

94/14 Anderson, K., "Trade, Environmental Issues, and AsianPacific Economic Growth", May 1994.

94/13 Anderson, K., "Why Should Australia Spend More on International Agricultural Research and Development?" May 1994.

94/12 Anderson, K., "Agricultural Policies and the New World Trading System", May 1994.

94/11 Stanford, L.J., "Regulation of the Grower-Miller Relationship in the Queensland Raw Sugar Industry", April 1994.

94/10 McLean, I., "Tasman Trade Relations: Decline and Rise", March 1994

94/09 Rogers, C., "Trade and Macroeconomic Policies", March 1994.

94/08 Bora, B., "International Factor Flows and Australia's Trade", March 1994.

94/07 Findlay, C., "Service Sector Policies", March 1994.

94/06 Bora, B. and R. Pomfret, "Policies Affecting Manufacturing", March 1994.

94/05 Anderson, K.and C. Findlay, "Policies Affecting Primary Sectors", March 1994.

94/04 Pincus, J., "Evolution and Political Economy of Australia's Trade Policies", February 1994.

94/03 Anderson, K., "Australia's Changing Trade Pattern and Growth Performance", February 1994.

94/02 Anderson, K., "The Entwining of Trade and Environmental Policies", February 1994.

94/01 Stanford, L.J., "The Effects of Regulation and Assistance in the Queensland Raw Sugar Industry", January 1994.

93/17 Anderson, K., "Multilateral Trade Negotiations, European Integration, and Farm Policy Reform", November 1993.

93/16 Findlay, C., B. Bora and P. Forsyth, "The Air Transport Industry in ASEAN", September 1993. 


\section{Table 28 (continued)}

93/15 Anderson, K., "Agricultural Policy: Constraint to Development", September 1993.

93/14 Anderson, K., "World Trade Issues Affecting Asian Economic Development", September 1993.

93/13 Anderson, K., "Crisis in the World Trading System and Australia's Response", August 1993.

93/12 Anderson, K. and C. Findlay, "Australian Trade Policy: The End of Tariff Protection?", June 1993.

93/11 Pincus, J.J., "Review of Michael Pusey's 1991 book on Economic Rationalism in Canberra", May 1993.

93/10 Anderson, K., "A Plain-Language Guide to the Agendas of OECD and GATT Working Groups on Trade and Environment Issues", May 1993.

93/09 Anderson, K., "Fibres, Textiles and Clothing in East Asia's Economic Development", April 1993.

93/08 Findlay, C. and D. Round, "The International Air Services Commission Capacity Allocation Rules and Their Impact on Competition", March 1993.

93/07 Anderson, K., "European Integration in the 1990s: Implications for World Trade and Australia", March 1993.

93/06 Anderson, K., "International Trade and Australian Protectionism", February 1993.

93/05 Brennan G.and Jo.J. Pincus, "Economic Rationalism Revisited: The Case of Countervailing Duties", February 1993.

93/04 Pincus, J.J., "Market Failure and Government Failure", February 1993.

93/03 Anderson, K., "GATT: Is It Still Relevant For Australia in the 1990s?" February 1993.

93/02 Anderson, K., "NAFTA, Excluded Pacific Rim Countries, and the Multilateral Trading System", January 1993.

93/01 Bora, B. and C. Findlay, "Regionalism in the World Economy: NAFTA and the Australian Response", January 1993.

\section{(2) CIES Seminar Papers}

(merged with CIES Discussion Papers after March 1999) 


\section{Table 28 (continued)}

99-03 Fredriksson, P. and N. Gaston, "The Importance of Trade for the Ratification of the 1992 Climate Change Convention", March 1999.

99-02 Wittwer, G. and K. Anderson, "Accounting for Growth in Australia's Grape and Wine Industries, 1987 to 2003", March 1999.

99-01 Anderson, K., “The WTO Agenda for the New Millennium”, January 1999.

98-11 Damania, R., "Influence in Decline: Lobbying in Contracting Industries", November 1998.

98-10 Anderson, K. (editor), “China's WTO Accession: Foreign Investment, Government Procurement, Grain Selfsufficiency, and Labour Standards", November 1998.

98-09 Sinclair, P. and D. Vines, “Asia's 'Open Regionalism' Alternative to Preferential Trade Agreements: Promising, Attractive, or Vulnerable to Cronyism?" October 1998.

98-08 Pomfret, R., "The Transition to a Market Economy, Poverty and Sustainable Development in Central Asia", October 1998.

98-07 Gaston, N., "Outsourcing Jobs and Enterprise-level Bargaining: 'Cheshire Cat' Unions Revisited?" August 1998.

98-06 Francois, J.F.and H. Horn, "Competition Policy in an Open Economy", August 1998.

98-05 Carr, D.L., J.R. Markusen and K. Maskus, "Testing the Knowledge-Capital Model of the Multinational Enterprise", July 1998.

98-04 Strutt, A. and K. Anderson, "Will Trade Liberalization Harm the Environment? The Case of Indonesia to 2020", May 1998.

98-03 Berger, N., "North-South Trade in Recyclable Waste: Economic Consequences of Basel", March 1998.

98-02 James, S. and K. Anderson, "On the Need for More Economic Assessment of Quarantine/SPS Policies", February 1998.

98-01 Francois, J.F. and D. Nelson, "A Geometry of Specialization", January 1998.

97-16 Maskus, K.E., “Strengthening Intellectual Property Rights in Asia: Implications for Australia", November 1997. 


\section{Table 28 (continued)}

97-15 Pomfret, R. and K.H. Anderson, “Uzbekistan: Welfare Impact of Slow Transition", November 1997.

97-14 Anderson, K., (editor), "China's WTO Accession: Financial Services, Intellectual Property, State Trading, and AntiDumping", November 1997.

97-13 Konan, D. and K.E. Maskus, "Joint Trade Liberalization and Tax Reform in a Small Open Economy: The Case of Egypt", October 1997.

97-12 Anderson, K. and J.F. Francois, “Commercial Links Between Western Europe and East Asia: Retrospect and Prospects", October 1997.

97-11 Maskus, K.E., “The International Regulation of Intellectual Property", October 1997.

97-10 Bosworth, M., C. Findlay, R. Trewin, and T. Warren, "Measuring Trade Impediments to Services within APEC", September 1997.

97-09 Yang, G. and K.E. Maskus, "Intellectual Property Rights, Licensing, and Economic Growth", August 1997.

97-08 Babiker, M.H., K.E. Maskus and T.F. Rutherford, "Carbon Taxes and the Global Trading System", August 1997.

97-07 Anderson, K. and W.J. McKibbin, "Reducing Coal Subsidies and Trade Barriers: Their Contribution to Greenhouse Gas Abatement", July 1997.

97-06 Pomfret, R., “International Capital Mobility and the Feldstein-Horioka Paradox: Evidence from Settler Economies in the Gold Standard Era", April 1997.

97-05 McLean, I.W., "Recovery from the 1890s Depression: Australia in an Argentine Mirror", March 1997.

97-04 Anderson, K., "Environmental and Labor Standards: What Role for the WTO?" March 1997.

97-03 Anderson, K., "Are Resource-Abundant Economies Disadvantaged?" March 1997.

97-02 Fredriksson, P.G., "The Political Economy of Trade Liberalization and Environmental Policy", February 1997.

97-01 Fredriksson, P.G., "Environmental Policy Choice: Pollution Abatement Subsidies", February 1997. 


\section{Table 28 (continued)}

96-21 Harris, R.G. and N. Schmitt, “Do Two Wrongs Make a Right? Export Incentives and Bias in Trade Policy", December 1996.

96-20 Naughton, B., “China's Dual Trading Regimes: Implications for Growth and Reform", December 1996.

96-19 Bagwell, K. and R.W. Staiger, "Regionalism and Multilateral Tariff Cooperation", December 1996.

96-18 Eaton, J. and S. Kortum, "Technology and Bilateral Trade", November 1996.

96-17 Taylor, M.S., “Trade and Trade Policy in Endogenous Growth Models: A Review and Suggestions for Research", November 1996.

96-16 Francois, J. and B. McDonald, "The Multilateral Trade Agenda: Uruguay Round Implementation and Beyond", November 1996.

96-15 Ethier, W.J., “Multilateral Roads to Regionalism”, October 1996.

96-14 Lindert, Peter H., "Soil Degradation and Agricultural Change in China and Indonesia", September 1996.

96-13 Anderson, K., B. Dimaranan, T. Hertel and W. Martin, "Economic Growth and Policy Reform in the APEC Region: Trade and Welfare Implications by 2005", September 1996.

96-12 Johnson, D.G., "Population, Food and Trade", September 1996.

96-11 Dean, J.M., “Testing the Impact of Trade Liberalization on the Environment", September 1996.

96-10 Hoang Van, P. and H.Y. Wan, Jr., "Emulative Development through Trade Expansions: East Asian Evidence", September 1996.

96-09 Anderson, J., "Trade Reform with a Government Budget Constraint", July 1996.

96-08 Mayer, W., “The Political Economy of Administered Trade Laws", July 1996.

96-07 Dhar, S. and A. Panagariya, "Is East Asia Less Open than North America and the EU?", July 1996

96-06 Lloyd, P., "Unilateral and Regional Trade Policies of the CER Countries", July 1996. 


\section{Table 28 (continued)}

96-05 Anderson, K., B. Dimaranan, T. Hertel and W. Martin, “AsiaPacific Food Markets and Trade in 2005: A Global, EconomyWide Perspective", July 1996.

96-04 Anderson, K. (editor), “Finding Common Ground: Mining, the Environment, and Indigenous Australians", March 1996.

96-03 Pomfret, R., "China's Trade Miracle”, February 1996.

96-02 Huang, J., S. Rozelle and M.W. Rosegrant, "China's Food Economy to the 21st Century: Supply, Demand, and Trade", January 1996.

96-01 Pomfret, R., "Australian Experience with Exporting to Asia”, January 1996.

95-16 Bora, B., “Trade and Investment in the APEC Region, 19801993", December 1995.

95-15 Riezman, R.G., P.M. Summers and C.H. Whiteman, "Trade Liberalisation, Exports and Economic Growth: A Bayesian Time-Series Perspective", November 1995.

95-14 Fredriksson, P.G., "Capital Mobility, Pollution Taxes, and Environmental Federalism", November 1995.

95-13 Corden, W.M., "The Environment and Trade Policy", November 1995.

95-12 Fredriksson, P.G., "The Political Economy of Pollution Taxes in a Small Open Economy", November 1995.

95-11 DeJong, D.N. and S. Husted, "Interpreting Empirical Evaluations of Exchange-Rate Models", October 1995.

95-10 Worrall, S.J., "Aquaculture and Ocean Fishery Regulation", October 1995.

95-09 Gaston, N. and D. Trefler, "The Labour Market Consequences of the Canada-US Free Trade Agreement", July 1995.

95-08 McDougall, R. and R. Tyers, "Developed Country Factor Market Effects of Asian Trade and Growth: Preliminary GTAP Experiments", May 1995.

95-07 Riezman, R.G., P.M. Summers and C.H. Whiteman, "The Engines of Growth in the APEC Economies, 1950-1990", April 1995.

95-06 Yang, X. and S. Ng, "Specialization and Division of Labor: A Survey", April 1995. 


\section{Table 28 (continued)}

95-05 Anderson, K. and M. Pangestu, "Agriculture and Rural Development in Indonesia into the 21st Century", April 1995.

95-04 Richardson, J.D. and P.J. Smith, "Sectoral Growth Across US States: Factor Content, Linkages, and Trade", April 1995.

95-03 Anderson, K., "Agricultural Competitiveness After the Uruguay Round", March 1995.

95-02 Rygnestad, H.L. and R.W. Fraser, "An Analysis of the Effectiveness of the Set-Aside Policy of the European Common Agricultural Policy", February 1995.

95-01 Anderson, K., "The Intrusion of Environmental and Labour Standards into Trade Policy", February 1995.

94-12 Turunen-Red, A.H. and A.D. Woodland, "Multilateral Reform of Quantity Restrictions on Trade", December 1994.

94-11 Anderson, K., "The Political Economy of Coal Subsidies in Europe", November 1994.

94-10 Krueger, A.O. and R. Duncan, "The Political Economy of Controls: Complexity", October 1994.

94-09 Krishna, K. and A.O. Krueger, "Implementing Free Trade Areas: Rules of Origin and Hidden Protection", September 1994.

94-08 Pomfret, R., "Locational Competitiveness in East Asia", July 1994.

94-07 Ohyama, M. and R.W. Jones, “Technology Change, Overtaking and Comparative Advantage", July 1994.

94-06 Anderson, K.and A. Strutt, "On Measuring the Environmental Effects of Agricultural Trade Liberalization", July 1994.

94-05 McCulloch, R. and P.A. Petri, "Equity Financing of Asian Development", May 1994.

94-04 Anderson, K. and R.H. Snape, "European and American Regionalism: Effects on and Options for Asia", May 1994.

94-03 Pomfret, R., "Trade Policy with Imperfect Competition: the Jet Aircraft Industry", April 1994.

94-02 Greenaway, D., R.C. Hine and C. Milner, "Country-Specific Factors and the Pattern of Horizontal and Vertical IntraIndustry Trade in the UK", March 1994. 


\section{Table 28 (continued)}

94-01 Pomfret, R., “What Can Other Economies in Transition Learn from China?" January 1994.

93-09 McLean, I.W., "No Flash in the Pan: Resource Abundance and Economic Growth in California 1848-1910", December 1993.

93-08 Lloyd, P.J., "Offshore Production and the Base of Import Taxation", December 1993.

93-07 Pomfret, R., "Monetary Reform in Azerbaijan", December 1993.

93-06 Pomfret, R., "The Choice of Exchange Rate and Monetary Policies in Countries of the Former Soviet Union", November 1993.

93-05 Ashenfelter, O. and A. Krueger, "Estimates of the Economic Returns to Schooling from a New Sample of Twins", October 1993.

93-04 Riezman, R.G., P.M. Summers and C.H. Whiteman, "The Engine of Growth or its Handmaiden? A Time Series Assessment of Export-Led Growth", September 1993.

93-03 Siegfried, J.J. and D.K. Round, "The Australian and American Undergraduate Economics Degrees: A Comparative Analysis", September 1993.

93-02 Anderson, K., "US-EC Farm Trade Confrontation: An Outsider's View", August 1993.

93-01 Anderson, K. and R. Tyers, "Implications of EU Expansion for European Agricultural Policies, Trade and Welfare", July 1993.

92-18 Anderson, K., "Intersectoral Changes in Transforming Socialist Economies: Distinguishing Initial from Longer Term Responses", December 1992.

92-17 Anderson, K., "Lobbying Incentives and the Pattern of Protection in Rich and Poor Countries", December 1992.

92-16 Bora, B.K. and C. Findlay, "Regionalism in the World Economy: NAFTA and the Australian Response", November 1992.

92-15 Dee, P., P. Jomini and R. McDougall, "Alternatives to Regionalism - Uruguay and APEC", July 1992. 


\section{Table 28 (continued)}

92-14 English, H.E., "Integration Theory and Practice Revisited: Implications for NAFTA and Pacific Economic Relations", July 1992.

92-13 Lewis, M.K., "Free Trade Areas and Financial Services", July 1992.

92-12 Findlay, C. and P. Forsyth, "Regionalism and Pacific Aviation", July 1992.

92-11 Bora, B.K., "Regional Trading Blocs, Country Size and Transport Costs: The Case of Australia", July 1992.

92-10 Bora, B.K., "The Effect of a North American Free Trade Agreement on Investment in Australia", July 1992.

92-09 Holland, K.M., “The Impact of the North America Free Trade Agreement on Federal Relations in Canada, The United States and Mexico", July 1992.

92-09 Lloyd, P.J., "An Australian Perspective on Free Trade Areas and Regional Trading Arrangements", July 1992

92-07 Pomfret, R.W.T., "The Global Perspective: Forces for Regionalism in World Trade", July 1992.

92-06 Snape, R.H., “Bilateral Initiatives: Should Australia Join?" July 1992.

92-05 Field, P.S., "Priorities in Australian Trade Policy", July 1992.

92-04 Kreinin, M.E. and M.G. Plummer, "Economic Effects of the North American Free Trade Area on Australia and New Zealand", July 1992.

92-03 Scollay, R., "North American Free Trade from a New Zealand Perspective: Lessons from CER and Implications for New Zealand's Trade", July 1992.

92-02 Higley, J. and M. Sutton, "Progress Report on the North American Free Trade Agreement and its Implications for US Trade Policy", July 1992.

92-01 Vanzetti, D., S. Hester and N. Andrews, "Implications of the North American Free Trade Agreement for Australian Agriculture", July 1992.

90-06 Tyers, R., "Agricultural Trade Reform and the Stability of Domestic and International Food Prices", July 1990. 


\section{Table 28 (continued)}

90-05 Anderson, K., “Agricultural Development and Trade of Pacific Rim Countries", July 1990.

90-04 Gibbard, P. and R. Tyers, "The Distributional Incidence of Commodity Price Stabilization in an Open Economy", June 1990.

90-03 Spriggs, J.D., “Transparency vs Protectionism: The Australian Way", June 1990.

90-02 Anderson, K. and R. Tyers, "Effects of Tariffication of Food Trade Barriers Following the Uruguay Round", May 1990.

90-01 Whalley, J., "The Multi-fibre Arrangement and China's Growth Prospects", January 1990.

89-11Lloyd, P.J., "Textiles, Clothing and Fibres in Australia and New Zealand", December 1989.

89-10 Sjaastad, L.A., "Exchange Rates and Commodity Prices: The Australian Case", November 1989 (and comments by R.H. Snape).

89-09 Pelzman, J., "The Redirection of United States Imports of Textiles and Clothing", November 1989.

89-08 Suphat S., "Thailand's Growth in Textile Exports", November 1989.

89-07 Hamilton, C.B., "The New Silk Road to Europe: New Conditions for Old Trade", November 1989.

89-06 Anderson, K. and R. Tyers, "How Developing Countries Could Gain from Agricultural Trade Liberalization in the Uruguay Round", October 1989.

89-05 Anderson, K., "China and the Multifibre Arrangement", August 1989.

89-04 Park, Y.I. and K. Anderson, "The Rise and Demise of Textiles and Clothing in Economic Development: The Case of Japan", August 1989.

89-03 Laidler, D., “The Quantity Theory is Always and Everywhere Controversial - Why?" July 1989.

89-02 Gardner, B.L., "Price Supports and Optimal Spending on Agricultural Research", May 1989.

89-01 Tyers, R., "Implicit Policy Preferences and the Assessment of Negotiable Trade Policy Reforms", May 1989. 


\section{Table 28 (continued)}

\section{(c) CIES Indonesia Project Working Papers}

02.02 Feridhanusetyawan, T. and M. Pangestu, "Indonesian Trade Liberalization: Estimating the Gains", December 2002.

02.01 Croser, J., "Impacts of trade policy reform on income distribution and poverty in Indonesia", November 2002.

01.02 Erwidodo, G. Wittwer and R. Stringer, "Effects of agricultural policy reform in Indonesia on its food security and environment", November 2001.

01.01 Bahri, S., R. Kustiari and G. Wittwer, "Effects of Farm Policy Reform on Indonesia's Secondary Food Crops", October 2001.

00.01 Feridhanusetyawan, T., M. Pangestu and Erwidodo, "Effects of AFTA and APEC trade policy reforms on Indonesian agriculture", October 2000.

99.26 Uphoff, N., "A Rural Development Strategy for Indonesian Recovery", March 1999.

99.25 Kasryno, F., H. Nataatmadja and B. Rachman, "Agricultural Development in Indonesia Entering the $21^{\text {st }}$ Century", March 1999.

99.24 Nikijuluw, V.P.H. and S. Bahri, "The Impact of the Economic Crisis on Production and Exports of Fish", March 1999.

99.23 Yusuf, G. and R. Dahuri, "The Impact of the Economic Crisis on Indonesia's Fishery Sector", March 1999.

99.22 Tangendjaja, B. and T. Sudjana, "The Impact of the Economic Crisis on Indonesia's Poultry Sector", March 1999.

99.21 Hadi, P.U., D. Vincent and N. Ilham, "The Impact of the Economic Crisis on Indonesia's Beef Sector", March 1999.

99.20 Ruf, F. and Y. Cira-Tera, "The Impact of the Economic Crisis on Indonesia's Cocoa Sector", March 1999.

99.19 Rusantra, I.W., R. Suprihatini and M. Iqbal, "The Sugar Development Strategy With an Economic Crisis and Competitive Markets", March 1999.

99.18 Arifin, S., B. Drajat, W.R. Susila and A. Supriono, "The Impact of the Economic Crisis on Development of the Estate Crops", March 1999. 


\section{Table 28 (continued)}

99.17 Bourgeois, R., "The Impact of the Crisis on Javanese Irrigated Rice Farmers", March 1999.

99.16 Levang, P., B.K. Yoza, D. Etty and H. Etty, "Not Every Cloud has a Silver Lining: Crop Farmers in Transmigration Areas", March 1999.

99.15 Simatupang, P., "Toward Sustainable Food Security: The Need for a New Paradigm", March 1999.

99.14 Sumodiningrat, G., "Economic Stabilization and the Social Safety net: Achieving Public Prosperity", March 1999.

99.13 Tabor, S., H.S.Dillon and M.H. Sawit, "Understanding the 1998 Food Crisis: Supply, Demand or Policy Failure?" March 1999.

99.12 Tambunan, M., "Economic Crisis Induced Management: Is Agriculture a Safe Haven?" March 1999.

99.11 Iwaran, P.B. and A. Susanto, "Impact of the Indonesian Crisis on the Number of Poor People", March 1999.

99.10 Wittwer, G., "Wayang: A General Equilibrium Model Adapted for the Indonesian Economy", March 1999.

99.09 Anderson K., Erwidodo, T. Feridhanusetyawan and A. Strutt, "Agriculture and the Next Round of WTO Negotiations", March 1999.

99.08 Feridhanusetyawan, T., "The Benefit of EVSL to APEC Economies: A General Equilibrium Analysis", March 1999.

99.07 Warr, P.G., "Indonesia's Crisis and the Agricultural Sector", March 1999.

99.06 Stringer, R., "The Impacts of Indonesia's Economic Crisis on Food Crops and Food Security", March 1999.

99.05 Erwidodo, R. Stringer and G. Wittwer (1999), "The Agriculturalization of Indonesia in the Aftermath of the Socio-economic Crisis", March 1999.

99.04 Anderson, K. and A. Strutt, "Indonesia's Economic Crisis: Can Agriculture be the Engine for Recovery?" March 1999.

99.03 Erwidodo, T. Feridhanusetyawan, T. Sudaryanto and S. Bahri, "Crisis-Induced Policy Reforms and Agricultural Liberalization in Indonesia", January 1999. 


\section{Table 28 (continued)}

99.02 Feridhanusetyawan, T., M. Pangestu and Erwidodo, "The Benefits of Agricultural Liberalization in Asia Pacific", January 1999.

99.01 Warr, P.G. and P.J. Thapa, "General Equilibrium Analysis of Rice Pricing Policy in Indonesia", January 1999.

98.10 Anderson, K. and A. Strutt, "Impact of East Asia's Growth Interruption and Policy Responses: The Case of Indonesia", November 1998.

98.09 Feridhanusetyawan, T., "Economic Crisis and Employment Problems in Indonesia", August 1998.

98.08 Erwidodo, "The Impacts of Trade Liberalization on Food Production and Farm Income: A Multilevel Modelling Approach", March 1998.

98.07 Stringer, R., "Policy Analysis of Agricultural Production, Trade, and the Environment: Research Issues for Indonesia's Horticultural Sector", March 1998.

98.06 Strutt, A., "Trade Liberalization and Land Degradation in Indonesia", March 1998.

98.05 Feridhanusetyawan, T., "The Impact of Trade Liberalization on Welfare and Employment in ASEAN", March 1998.

98.04 Pasaribu, S.M. and S. Bahri, "Recent Adjustments to Indonesia's AFTA CEPT Scheme", March 1998.

98.03 Bahri, S., A. Suryana and Erwidodo, "Implications of Indonesia's Monetary Crisis for Agroindustry Development", March 1998.

98.02 Strutt, A. and K. Anderson, "Will Uruguay Round and APEC Trade Liberalization Harm the Environment in Indonesia?" March 1998.

98.01 Trewin, R., K. Menz and P. Grist, "Estimates of Local and Economy-wide Costs and Benefits of Land Uses in the Indonesian Uplands through Linked Biological and Economic Models", March 1998.

97.13 Strutt, A., "On Modelling Structural Change in Indonesia: 1992-2020", August 1997.

97.12 Stringer, R., "Food Security, Poverty and Environmental Linkages in Indonesia: Issues for Research", August 1997. 


\section{Table 28 (continued)}

97.11 Stringer, R., "Harmonization, Multilateral Environment Agreements and Agriculture: Potential Issues for Indonesia", August 1997.

97.10 Feridhanusetyawan, T., "Changing Trade Patterns and the Impact of Trade Liberalization in Asia Pacific", August 1997.

97.09 Kustiari, R., Erwidodo and S. Bahri, "Indonesia's Agricultural Trade Policies: A Review", August 1997.

97.08 Bahri, S. and A. Suryana, "Indonesia's Environmental Rules and Regulations Relating to Agricultural Investment: A Review", August 1997.

97.07 Anderson, K. and M. Pangestu, "Structural Changes in a Reforming World Economy: Implications for Indonesia", August 1997.

97.06 Warr, P.G. and M. Azis, "INDOSAM: A Balanced and Disaggregated 1993 Social Accounting Matrix for Indonesia", January 1997.

97.05 Trewin, R., "Further Analysis of Linkages between Indonesian Agriculture, Agribusiness and the Macroeconomy", January 1997.

97.04 Erwidodo and T. Feridhanusetyawan, "Indonesia's Agriculture: Facing APEC and WTO", January 1997.

97.03 Erwidodo and A. Suryana, "Trade Reforms and Agricultural Trade Performance in Indonesia", January 1997.

97.02 Strutt, A., "Economic and Environmental Implications of Trade Liberalization for Indonesia", January 1997.

97.01 Warr, P.G., "Incorporating Land Degradation into Applied General Equilibrium Models", January 1997.

\section{(d) CIES monographs}

Goode, W. (2003), Dictionary of Trade Policy Terms, $4^{\text {th }}$ edition, Cambridge and New York: Cambridge University Press, copublication with the World Trade Organization and the Centre for International Economic Studies. 


\section{Table 28 (continued)}

Anderson, K. and D. Norman (2003), Global Wine Production, Consumption and Trade, 1961 to 2001: A Statistical Compendium, Adelaide: Centre for International Economic Studies.

Goode, W. (1997, 1998, 2002), Dictionary of Trade Policy Terms, Adelaide: Centre for International Economic Studies, $1^{\text {st }}, 2^{\text {nd }}$ and $3^{\text {rd }}$ editions. (Also published in Chinese by the University of International Business and Economics Press, Beijing, 2001, in Korean by the Ministry of Finance and Economy, Seoul, 1998, and in Vietnamese by the Ministry of Trade, Hanoi, 1997).

Stringer, R., T. Feridhanusetyawan, T. Sudaryanto and K. Anderson (eds.) (2002), Indonesia in a Reforming World Economy: Effects on Agriculture, Trade and the Environment, Adelaide: Centre for International Economic Studies.

Francois, J. (2001), The Next WTO Round: North-South Stakes in New Market Access Negotiations, Adelaide: Centre for International Economic Studies and Amsterdam \& Rotterdam: Tinbergen Institute.

Anderson, K. and D. Norman (2001), Global Wine Production, Consumption and Trade, 1961 to 1999: A Statistical Compendium, Adelaide: Centre for International Economic Studies.

Anderson, K. (ed.) (2001), Australia's Economy in its International Context: The Joseph Fisher Lectures Adelaide: Centre for International Economic Studies (2 volumes).

Anderson, K., C. McRae and D. Wilson (eds.) (2001), The Economics of Quarantine and the SPS Agreement, Adelaide: Centre for International Economic Studies and Canberra: AFFA Biosecurity Australia.

Bosworth, M. and K. Anderson (2000), Reforming Trade Policy in Papua New Guinea and the Pacific Islands: What Roles for WTO and APEC? Adelaide: Centre for International Economic Studies and Port Moresby: Institute of National Affairs.

Stringer, R., S. Bahri, M.S. Pasaribu and P. Simatupang (eds.) (1999), Indonesia's Economic Crisis: Effects on Agriculture and Policy Responses, Adelaide: Centre for International Economic Studies. 


\section{Table 28 (continued)}

Berger, N., Spahni, P. and Anderson, K. (1999), Bilateral Trade Patterns in the World Wine Market, 1988 to 1997: A Statistical Compendium, Adelaide: Centre for International Economic Studies.

Anderson, K. (1998), Economic Reform in Nepal and WTO Accession, Adelaide: Centre for International Economic Studies.

Anderson, K. (1998), Lao Economic Reform and WTO Accession, Adelaide: Centre for International Economic Studies and Singapore: Institute of Southeast Asian Studies.

Anderson, K. (1998), Vietnam's Transforming Economy and WTO Accession, Adelaide: Centre for International Economic Studies and Singapore: Institute of Southeast Asian Studies.

Berger, N., K. Anderson and R. Stringer (1998), Trends in the World Wine Market, 1961 to 1996: A Statistical Compendium, Adelaide: Centre for International Economic Studies.

Wittwer, G. and K. Anderson (1998), Tax Reform and the Australian Wine Industry, Adelaide: Centre for International Economic Studies.

Osmond, R. and K. Anderson (1998), Trends and Cycles in the Australian Wine Industry, 1850 to 2000, Adelaide: Centre for International Economic Studies.

Anderson, K. (ed.) (1996), Strengthening the Global Trading System: From GATT to WTO, Adelaide: Centre for International Economic Studies. 
Table 29: Chinese Economies Research Centre working papers, 1990-1999

98-05 Cheng, Enjiang, "Household Heads, Non-Economic Factors and Grain Production in China in the 1990s," 1998.

98-04 Chen, Jiyuan, Zhu, Gang and Liu, Yuman, " Rural Non-Bank Financial Institutions in Underdeveloped Areas - A Case Study of a County of Henan Province," 1998.

98-03 Watson, Andrew, "Enterprise Reform and Employment Change in Shanxxi Province," 1998.

98-02 Yuan, Shiming, " Key Issues in Establishing a New Housing System Based on a Market Oriented Economy," 1998

98-01 Du, Zhixiong, " The Dynamics and Impact of the Development of Rural Cooperative Funds (RCFs) in China," 1998.

97-18 Dickson, Ian, "China's Myriad Customs Regimes and their Implications for Openness (with reference to steel imports)," 1997.

97-17 Dickson, Ian, "Testing the Hypothesis of Irrational Exuberance in China's Steel Imports, 1992-1996," 1997.

97-16 Chunlai, Chen, "Provincial Characteristics and Foreign Direct Investment Location Decision within China," 1997.

97-15 Chunlai, Chen, "The Evolution and Main Features of China's Foreign Direct Investment Policies," 1997.

97-14 Chunlai, Chen, "Comparison of Investment Behaviour of Source Countries in China," 1997.

97-13 Chunlai, Chen, "The Composition and Location Determinants of Foreign Direct Investment in China's Manufacturing," 1997.

97-12 Chunlai, Chen, "The Location Determinants of Foreign Direct Investment in Developing Countries," 1997.

97-11 Chunlai, Chen, "Foreign Direct Investment and Trade: An Empirical Investigation of the Evidence from China," 1997.

97-10 Yuan, Shiming, "Evaluation of China's Urban Housing Reform," 1997.

97-09 Lan, Yisheng and Zhaoyang, Peng, "China's Fishery Industry: Production, Consumption and Trade," 1997. 


\section{Table 29 (continued)}

97-08 Lan, Yisheng, "Foreign Direct Investment and Economic Development in Guangdong: Problems and Prospects," 1997.

97-07 Lan, Yisheng, "The Stock Market in China: Problems and Prospects for Domestic and Foreign Investment," 1997.

97-06 Hehui, Jin and Du, Zhixiong, "Productivity of China's Rural Industry in the 1980's," 1997.

97-05 Bora, Bijit and Chunlai, Chen, "The Internationalisation of China and its Implications for Australia," 1997.

97-04 Findlay, Christopher and Wu, Harry X., "China's Grain Demand and Supply: Trade Implications," 1997.

97-03 Dickson, Ian, "Risks and Documentary Credits in China's International Metals Trade," 1997.

97-02 Cheng, Enjiang, Findlay, Christopher and Watson, Andrew, "Internal Reform, Budget Issues and the Internationalisation of the Grain Market in China," 1997.

97-01 Findlay, Christopher, "Grain Sector Reform in China," 1997.

96-13 Dickson, Ian, "The Sino-Japan Steel Trade Negotiations Framework," 1996.

96-12 Johnson, D. Gale, "China's Rural and Agricultural Reforms: Successes and Failures." 1996.

96-11 Hong, Yang, "China's Maize Production and Supply from a Provincial Perspective," 1996.

96-10 Hong, Yang, "Trends in China's Regional Grain Product and their Implications," 1996.

96-09 Hong, Yang, "Sources of Productivity Disparities in Regional Grain Production in China," 1996.

96-08 Peng, Chao Yang, "Challenges to China's Energy Security," 1996.

96-07 Wu, Yanrui, "Changing Patters of Alcohol Consumption in Rural China: Implications for the Grain Section," 1996.

96-06 Dickson, Ian, "China's Steel Imports: An Outline of Recent Trade Barriers," 1996.

96-05 Watson, Andrew and Findlay, Christopher, "Economic growth and trade dependency in China," 1996.

96-04 Wu, Harry X., and Zhou, Li, "Research on Rural-to-Urban Labour Migration in the Post-Reform China: A Survey,"1996. 


\section{Table 29 (continued)}

96-03 Chunlai, Chen, "Recent Developments in Foreign Direct Investment in China,"1996.

96-02 Wu, Guobao, Richardson, Sue and Travers, Peter, "Rural Poverty and Its Causes in China,"1996.

96-01 Wu, Guobao, Richardson, Sue and Travers, Peter, "Multiple Deprivation in Rural China,"1996.

95-08 Cheng, Enjiang and Malcolm, L.R., " Provision of Institutional Credit and Economic Transition in Rural China," 1995

95-07 Cheng, Enjiang and Findlay, Christopher, "Trade Reforms and Integration of China's Domestic and International Grain Markets since the middle 1980s - the Case of Wheat and Maize," 1995.

95-06 Meng, Xin and Wu, Harry X., "Relocation of Farm Household Labours and Its Direct and Indirect Impacts on Grain Production in China," 1995.

95-05 Findlay, Christopher, Wu, Harry X. and Watson, Andrew, “ Fiscal Decentralisation, Regionalism and Uneven Development in China," 1995.

95-04 Meng, Xin and Wu, Harry X., "Household Income Determination and Regional Income Differential in Rural China," 1995.

95-03 Lim, Steven, "Cointegration Analysis of Chinese Grain Performance 1961-1992,"1995.

95-02 Hong, Yang and $\mathrm{Wu}$, Yanrui, "Growth and Productivity in Chinas Agriculture: A Review,"1995.

95-01 Cheng, Enjiang and Wu, Yanrui, "Market Reform and Integration in China in the early 1990s - The Case of Maize,"1995.

94-16 Cheng, Yuk-shing, "Macroeconomic Management under Partial Reform: China's Economic Upswing in 1992-94," 1994.

94-15 Wu, Harry X., "Reforms of China's Foreign Exchange Regime: Behind Unification," 1994.

94-14 Wu, Yanrui and Xu, Harry X., "Household Grain Consumption in China: Effects of Income, Price and Urbanisation," 1994. 


\section{Table 29 (continued)}

94-13 Cheng, Enjiang, "Financial Issues and the Forces for Grain Marketing Reforms in China," 1994.

94-12 Cheng, Enjiang, "Comparison of Chinese and International Grain Prices," 1994.

94-11 Liew, Leong H., "Modelling Inter-Regional Strategic Interactions with a General Equilibrium Framework," 1994.

94-10 Wu, Yanrui, "Rice Markets in China in the 1990s," 1994.

94-09 Pomfret, Richard, "Direct Foreign Investment in China," 1994.

94-08 Lim, Steven, "Rural Industry - Interactions with Agriculture and State Industry," 1994.

94-07 Lim, Steven, "A Potential Inconsistency in "Dynamic" Socialism," 1994.

94-06 Wu, Yanrui, and Xu, Harry X., "Productivity and Sources of Growth in the Reforming Chinese Economy," 1994.

94-05 Wu, Yanrui, "Productivity Growth, Technological Progress and Technical Efficiency Change in China: A Three Sector Analysis," 1994.

94-04 Watson, Andrew, "China's Agricultural Reforms: Experiences and Achievements of the Agricultural Sector in the Market Reform Process," 1994.

94-03 Watson, Andrew, "Market Reform and Agricultural Development in China," 1994.

94-02 Carter, Colin and Zhang, Bin, "Rural Reforms, the Weather, and Productivity Growth in China's Grain Sector" 1994.

94-01 Yang, Hong, "The Role of Prices in China's Grain Production during the Post Reform Period," 1994.

93-09 Nguyen, D.T. and Wu, Harry X., " The Impacts of Economic Reforms on Chinese Agricultural Performance," 1993.

93-08 Bing, Jiang, "China's Dual Land Ownership System: Formation and Problems," 1993.

93-07 Bing, Jiang, "China's Experiment with a Quasi-Land Market: The Sale and Transfer of Land Use Rights," 1993.

93-06 Zhang, Xiaohe, "Modelling China's Rural Economy," 1993.

93-05 Wu, Harry X., "A Method for Estimating China's Rural GDP," 1993. 


\section{Table 29 (continued)}

93-04 Pomfret, Richard, "The Sequencing of Economic Reform," 1993.

93-03 Zhang, Xiaohe, "Domestic Distortions, Production and International Trade in China: An Analytical Framework," 1993.

93-02 Wu, Yanrui, "One Industry, Two Regimes: The Chinese Textile Sector Growth, Reforms and Efficiency," 1993.

93-01 Wu, Yanrui, "The Measurement of Efficiency: A Review of the Theory and Empirical Applications to China ." 1993.

92-07 Wu, Yanrui, "Productivity Performance of Chinese Rural Enterprises: A Comparative Study," 1992.

92-06 Wu, Harry X., "The "Industrialisation" of China's Rural Labour Force Since the Economic Reform," 1992.

92-05 Wu, Harry X., "China's Rural Economic Performance during the Reform Decade: Estimates and Assessments," 1992.

92-04 Watson, Andrew and Findlay, Christopher, "Issues in Fiscal Contracting in China," 1992.

92-03 Findlay, Christopher, Watson, Andrew and Zhang, Xiaohe, "Growth of Rural Enterprises, Urban-Rural Relations and China's Foreign Trade," 1992.

92-02 Yang, Hong, "Productivity Changes and Regional Disparities in Chinese Agriculture since 1980," 1992.

92-01 Martin, Will and Zhaoyang, Peng, "Using a CGE Model to Analyse External Shocks in the Reformed Chinese Economy: A Background Paper," 1992.

91-16 Chunlai, Chen, Findlay, Christopher and Watson, Andrew, "One State - Two Economies: Current Issues in China's Rural Industrialisation," 1991.

91-15 Martin, Will and Zhaoyang, Peng, "Oil Price Shocks and Policy Responses in the Post-Reform Chinese Economy," 1991.

91-14 Findlay, Christopher, Keliang, Sun, Watson, Andrew, Weiguo, Lu and Zhang, Xiaohe, "The 'Wool War' and the 'Cotton Chaos': Fibre Marketing in China," 1991. 


\section{Table 29 (continued)}

91-13 Findlay, Christopher, Qing-zeng, Li and Watson, Andrew, "Grain Production and Regional Economic Change in China," 1991.

91-12 Young, Susan, "Private Business and the State in China's Reforming Economy," 1991.

91-11 Wu, Yanrui, "Efficiency Differentials and their Potential Sources in Chinese Iron and Steel Industry," 1991.

91-10 Qing-Zeng, Li, "Government Control of Grain Production in China," 1991.

91-09 Wu, Harry X., “China's Labour Force Sectoral Transformation and Economic Growth in 1953-1989," 1991.

91-08 Wu, Harry X., "China's Urbanization and Rural-to-Urban Migration: Estimates and Analysis in a Perspective of Economic Development in Pre- and Post-Reform Periods," 1991.

91-07 Wu, Harry X., “The "Real" Chinese Gross Domestic Product (GDP) in the Pre-Reform Period 1952-1977," 1991.

91-06 Sheng, Yuming, "Who Provided Industrialization Funds in China?" 1991.

91-05 Wu, Yanrui, "Scale, Factor Intensity and Efficiency: Applications to the Chinese Coal Industry," 1991.

91-04 Zhang, Xiaohe, "The Urban Rural Isolation and its impact on China's Production and Trade Pattern," 1991.

91-03 Forster, Keith, “China's Tea War," 1991.

91-02 Zhang, Xunhai, "Enterprise Response to Market Reforms: the Case of the Bicycle Industry (1979-1988)," 1991.

91-01 Zhang, Xiaohe, "The Classification of China's Industries by Factor Intensity and the Corresponding Trade Pattern of China," 1991.

90-03 Anderson, Kym, "Urban Household Subsidies and Rural Out-Migration: The Case of China," 1990.

90-02 Wu, Yanrui, "Rural Industrialization in China: A General Equilibrium Analysis," 1990.

90-01 Anderson, Kym, "China's Economic Growth, Changing Comparative Advantages and Agricultural Trade," 1990. 